\author{
UNIVERSIDADE DE SÃO PAULO \\ FACULDADE DE FILOSOFIA, LETRAS E CIÊNCIAS HUMANAS \\ DEPARTAMENTO DE LETRAS MODERNAS \\ PROGRAMA DE PÓS-GRADUAÇÃO EM LÍNGUA E LITERATURAS ESPANHOLA E \\ HISPANO-AMERICANA
}

\title{
JORGE SEMPRÚN: FORMA PRECÁRIA E LITERATURA DE TESTEMUNHO
}

\author{
Marcia Romero Marçal
}

\begin{abstract}
Tese apresentada ao Programa de PósGraduação em Literatura Espanhola, do Departamento de Língua Espanhola e Literaturas Espanhola e HispanoAmericana da Faculdade de Filosofia, Letras e Ciências Humanas da Universidade de São Paulo, para obtenção do título de Doutor em Letras.
\end{abstract}

Orientadora: Prof. Dra. Valeria De Marco

São Paulo

2008 
FACULDADE DE FILOSOFIA, LETRAS E CIÊNCIAS HUMANAS DEPARTAMENTO DE LETRAS MODERNAS

PROGRAMA DE LITERATURA ESPANHOLA CONTEMPORÂNEA

\title{
JORGE SEMPRÚN: FORMA PRECÁRIA E LITERATURA DE TESTEMUNHO
}

\author{
Marcia Romero Marçal
}

São Paulo

2008 
A minha mãe, Luzia, porque em sua prosa mineira criei o gosto pela literatura.

A meu pai, Cándido, porque seu senso de justiça e seu carinho me ajudam a fazer escolhas.

A Lim, porque el tiempo pasa...

A Gabriel, Maíra e Alexandre, meus queridos. 
A Valeria De Marco por me orientar há nove anos nesse caminho. Por me amparar nos momentos de queda e elevar minha visão nas paragens mansas das planícies. Pelo respeito às minhas idéias, aos meus limites e pelo carinho.

Ao CNPq pela bolsa concedida, que nos proporciona outro tempo de reflexão.

A Ester pela paciência e carinho.

A Ariovaldo Vidal, porque em suas aulas nasceu a idéia que deu origem a esse trabalho. Por sua simpatia e colaboração.

A José Antonio Pérez Bowie por ter me convidado como orientador de meus estudos na Espanha.

À Fundação Carolina pela bolsa concedida na Espanha. Graças a ela, pude ter acesso aos textos da fortuna crítica do autor.

A Andréa Mostaço pelas traduções e pela amizade de tantos anos.

A Jorge por me ajudar a crescer.

A Fenelon, Kelli, Nágila e Michel, ajudantes mágicos.

A Edite por atender às solicitações sempre com generosidade. 
A tese dedica-se ao estudo de La escritura o la vida de Jorge Semprún. Examina como na obra o narrador, sobrevivente do campo de concentração de Buchenwald, desenvolve uma trajetória dialética para poder narrar sua experiência do campo: primeiro nega sua identidade de sobrevivente para, 47 anos depois, assumi-la na escrita como negatividade que põe em risco permanente sua vida como escritor testemunha da catástrofe. A história dessa superação provisória e permanente da negatividade do campo estrutura-se mediante a fragmentação textual e o diálogo. A contraposição da voz do narrador a vozes de outras personagens e a textos diversos indica que somente através da fragmentação discursiva ele pôde aproximarse do horror vivenciado no campo, pois ela se lhe apresenta como o único modo de exprimir a dialética entre a necessidade do diálogo do narrador com seu passado e a impossibilidade de com ele reconciliarse. A precariedade do sobrevivente objetiva-se na forma precária do romance, marca de singularidade desta obra de Semprún na literatura de testemunho.

\section{PALAVRAS-CHAVE}

Jorge Semprún - La escritura o la vida - literatura de testemunho forma precária - dialética e fragmentação 
La tesis se dedica al estudio de La escritura o la vida de Jorge Semprún. Examina como en la obra el narrador, superviviente del campo de concentración de Buchenwald, desarrolla una trayectoria dialéctica para poder narrar su experiencia del campo: primero niega su identidad de superviviente para, 47 años después, asumirla en la escritura como negatividad que pone en riesgo permanente su vida como escritor testigo de la catástrofe. La historia de esa superación provisional y permanente de la negatividad del campo se estructura mediante la fragmentación textual y el diálogo. La contraposición de la voz del narrador a voces de otros personajes y a textos diversos señala que sólo a través de la fragmentación discursiva el narrador pudo acercarse al horror vivenciado en el campo, pues ella se le presenta el único modo de expresar la dialéctica entre la necesidad del diálogo del narrador con su pasado y la imposibilidad de reconciliarse con éste. La precariedad del superviviente se objetiva en la forma precaria de la novela, marca de la singularidad de esta obra de Semprún en la literatura de testimonio.

\section{PALABRAS CLAVE}

Jorge Semprún - La escritura o la vida - literatura de testimonio forma precaria - dialéctica y fragmentación

\section{ABSTRACT}


The thesis devotes itself to the study of La escritura o la vida by Jorge Semprún. It examines how the narrator, a survivor from Buchenwald's concentration camp, develops in the work a dialectic trajectory in order to be able to narrate his experience at the camp: firstly denying his identity as a survivor for, 47 years later, assuming it in the writing as a negativity that puts a permanent risk on his life as a witness writer of the catastrophe. The history of this temporary and permanent overcoming of the negativity of the camp structures itself through textual fragmentation and dialogue. The contraposition of the narrator's voice to the voices of other characters and to different texts points that it was only through discursive fragmentation that he could come closer to the horror experienced at the camp, since it presents itself to him as the only way to express the dialectics between the narrator's necessity of dialogue with his past and the impossibility of reconciling himself with it. The survivor's precariousness objectifies itself in the precarious form of the novel, a mark of uniqueness of this work by Semprún in the literature of testimony.

\author{
KEY WORDS \\ Jorge Semprún - La escritura o la vida - literature of testimony - \\ precarious form - dialetic and fragmentation
}

\title{
$\underline{\text { ÍNDICE }}$
}


1. Introdução 1

2. O enredo dialético de La escritura o la vida 20

3. Tese: a fusão como aporia do regresso à vida 27

3.1. O reflexo do Mal: a cegueira 28

3.2. O eco do Mal: a voz da agonia e a agonia do silêncio

3.3. As fronteiras do Mal: a ausência de perspectiva e a perspectiva da ausência

3.4. A tradução do Mal: a perda do sentido do regresso e a origem do sentido da perda

3.5. A transposição do Mal: a variação do jazz sob a solidão da neve

4. Antítese: a camuflagem como aporia

do regresso da vida

4.1. A lembrança que sepulta

4.2. O túmulo esquecido

5. Síntese: a diferenciação como aporia do regresso da morte e à morte

5.1. A invasão do Mal do campo na escrita

5.2. A expulsão do Mal do campo à escrita

5.3. O encontro: a busca incessante do sentido da identidade e da identidade do sentido

6. Considerações finais: 
a estrutura dialógica-dialética fragmentária do texto como objetivação formal da precariedade

7. Referências Bibliográficas

7.1. Obras de Jorge Semprún

7.2. Fortuna Crítica de Jorge Semprún 
Apenas uma coisa permanecia ao alcance, próxima e protegida em meio a todas as perdas: a linguagem. Sim, a linguagem. A despeito de tudo, ela permanecia protegida contra a perda. Porém, teve de passar por sua própria falta de respostas através do silêncio aterrador e dos milhares de trevas do discurso assassino. Ela passou. Não me ofertou palavras para o que estava acontecendo, mas passou. Passou e pôde voltar à superfície, enriquecida por tudo aquilo.

Paul Celan

\section{Introdução}


O tema desta tese situa-se no âmbito das reflexões sobre a forma do romance, desenvolvidas pela crítica e teoria literária. As mudanças e inovações formais introduzidas na representação da realidade pela arte, em geral, pela literatura e particularmente pelo romance, no século xx, são objeto de estudo da crítica e da teoria literária.

As diversas manifestações artísticas mantêm uma mútua influência e refletem uma visão de mundo também esboçada e desenvolvida nas esferas das ciências e da filosofia. Desta forma, o fluxo de consciência, o monólogo interior, a fusão entre os níveis temporais, o desaparecimento do narrador onisciente do padrão do realismo do século XIX, o esgarçamento da causalidade da ação narrativa, a abolição do enredo fechado, a ausência de um eixo organizador da narração, o enfoque microscópico da vida psíquica, a dissolução dos contornos nítidos da personagem, o espaço sugerido e descrito a partir de impressões subjetivas, entre outros, são recursos técnicos que no romance relativizam a representação do espaço, do tempo e da causalidade. Tais construções passam a serem concebidas como fruto de uma consciência individual, suscetível a ilusões, o que Ihes outorga uma realidade às vezes questionável. Em última instância, a estética do romance contemporâneo refletiria, segundo Anatol Rosenfeld ${ }^{1}$, a precariedade do sujeito em um mundo caótico, cujas transformações constantes e velozes, as catástrofes históricas e o cotidiano caracterizado pelo choque provocam um sentimento de insegurança e a perda da confiança neste mundo. $O$ homem, ameaçado pelos progressos técnicos e por uma realidade social cujos valores e conhecimentos em permanente transição não lhe permitem sentir-se em um mundo estável, abdica de uma explicação que aspira à totalidade, de uma retórica racionalista tradicional, de uma objetividade científica, incorporando novas técnicas à estrutura da obra que representem essa nova experiência histórica e pessoal.

\footnotetext{
${ }^{1}$ ROSENFELD, Anatol. "Reflexões sobre o romance moderno" in Texto/contexto I. São Paulo: Perspectiva, 1996, p. 75-97.
} 
À semelhança de Anatol Rosenfeld, Andrés Amorós ${ }^{2}$ traça um paralelo entre o romance realista decimonônico e o romance contemporâneo, frisando alguns aspectos para o entendimento desta transformação estética. Novamente a base explicativa diz respeito ao contexto histórico: a realidade estável do progresso positivista e racionalista é abalada, torna-se intranqüila, volátil. Amorós arrola uma série de acontecimentos históricos que engendram esse sentimento de mundo, tais como as duas grandes guerras mundiais, o extermínio dos judeus, as revoluções comunistas de massas, a bomba atômica, o existencialismo, a divisão do mundo em blocos, as ditaduras no terceiro mundo, os totalitarismos e autoritarismos, a luta de classes, a ruptura do racionalismo com as inovações estéticas do futurismo, etc. O resultado é uma forma de romance que nos comunica a complexidade e a desordem enigmática da consciência das personagens e de seu meio. A incongruência, a linguagem elíptica, a incompletude do cenário, a desconexão da ação, a forma labiríntica e sugestiva, o inacabado e a imperfeição, conjugados na obra aberta, perfilam o romance do século XX como o romance da "crise".

Ao tratar da forma da literatura contemporânea, Amorós analisa certos aspectos também levantados por Rosenfeld e outros menos abordados pelo último, tais como: a ausência de um tema único, central, em proveito de uma gama temática ampla; a retomada irônica dos mitos como vocação metafísica à sondagem dos abismos do homem; a variedade da condição social dos protagonistas e a reprodução de sua expressão peculiar; a exploração dos mundos onírico e simbólico; o tratamento fragmentado e descontínuo da sucessão temporal, carregando a narração de lacunas e "tempos mortos"; a libertação do princípio de verossimilhança; o entrecruzamento de diversas histórias; o desejo de testemunhar a vida social e íntima, gerando biografias que ao mesmo tempo apresentam um caráter histórico e atemporal; a mescla e indefinição de gêneros, etc.

\footnotetext{
${ }^{2}$ AMORÓS, Andrés. Introducción a la novela contemporánea. Madrid: Ediciones Cátedra, 1989.
} 
Talvez um dos primeiros a observar essa inovação formal e temática na narrativa contemporânea tenha sido Erich Auerbach ${ }^{3}$. Em "A meia marrom", o pensador destaca alguns aspectos dessa mudança na representação da realidade ocorrida na literatura do século xx, como: as incertezas e as interrogações do escritor em relação à verdade da interpretação dos fatos e das personagens, reproduzindo sua impressão subjetiva dos mesmos; a representação consciente pluripessoal; a estratificação temporal; o relaxamento da conexão com os acontecimentos externos; a alternância do ponto de vista; a quebra da ordenação hierarquizada da estrutura narrativa - aspectos estes que levam a uma ruptura da unidade do texto e que implicam uma renúncia do escritor a representar com segurança objetiva a realidade.

Ciente da inserção da literatura de testemunho neste contexto histórico que modula a narrativa contemporânea, Valeria De Marco afirma que procedimentos como "a fragmentação, a exposição da prevalência da forma, a pluralidade de vozes, a justaposição de imagens ou pontos de vista, a ruptura com a ilusão realista, os ensaios de representação dos movimentos psíquicos, o amálgama de diferentes linguagens, (...) a aversão à linearidade ou à referencialidade, a tendência a representar a crise da noção de sujeito no mundo da automação, da técnica e dos meios de comunicação de massa" ${ }^{\text {"4 }}$ podem ser encontrados na literatura de testemunho, singularizados segundo a obra, em prol de sua eficácia estética.

É no âmbito desse legado interpretativo que a problemática mais ampla de nossa tese se inscreve ao analisar como a literatura de testemunho, através do caso particular de La escritura o la vida, de Jorge Semprún, vale-se de tais procedimentos, quer radicalizando-os, quer resgatando e transformando a tradição realista, a fim de representar a experiência do extremo que caracteriza a condição precária de seu narrador. A precariedade da forma na narrativa contemporânea e, dentro dela, de maneira mais radical e ineludível, na literatura de testemunho,

\footnotetext{
3 AUERBACH, Erich. Mimesis-a representação da realidade na literatura ocidental. São Paulo: Perspectiva, 2002.

${ }^{4}$ DE MARCO, Valeria. "A literatura de testemunho e a violência de Estado" in Lua nova, São Paulo, n. 62, 2004, p. 61.
} 
pressupõe um sujeito histórico precário, um narrador precário, que se relaciona com um mundo precário. As manifestações da precariedade da matéria na forma podem ser observadas, grosso modo, como insuficiência, fragmentação, descontinuidade, impossibilidade de totalidade. Entendemos que as irresoluções, os impasses, as contradições (lógicas ou dialéticas) e o inacabado na narrativa do século xx fazem-se sentir mais fortemente na literatura de testemunho.

O precário reside tanto na matéria como na forma narrativa do texto escolhido. A experiência vivida por este narrador e escritor, como prisioneiro do campo de concentração de Buchenwald, entre janeiro de 1944 e abril de 1945, diz respeito a uma situação extrema cujas conseqüências para sua vida posterior foram sentidas pelo mesmo em forma de uma identidade problemática. Durante um longo período de sua vida após a libertação do campo, o sobrevivente só pôde continuar sobrevivendo a expensas de negar sua história de sobrevivente e sua vontade de ser escritor. A história de La escritura o la vida concerne à história de uma alienação radical, a da vivência da morte, refletida em outra alienação radical, a da negação da identidade de sobrevivente do campo de Buchenwald, mediante a negação da atividade literária. A superação desta alienação radical transformase, por sua vez, em um processo permanente de superação por meio de sua elaboração literária. Trata-se da história de um eu que viveu a catástrofe de Buchenwald, a presença onipresente externa e objetiva da morte, e que de certa maneira se transformou em um sobrevivente que carrega em si a possibilidade iminente desta catástrofe subjetivada em sua singularidade individual. Ele procura lutar contra esta ameaça iminente de suicídio através da assunção de sua negatividade na atividade literária. $\mathrm{O}$ romance representa como o personagemnarrador, no processo de reconstrução de sua vida após Buchenwald, contraditoriamente passou por uma fase de negação da identidade de sobrevivente e como esse período de negação engendrou novas condições psicológicas que permitiram que esse eu fosse posteriormente reintegrado, possibilitando a elaboração escrita dessa transformação, que, por sua vez, põe em risco sua sobrevivência de escritor testemunha da catástrofe. 
$\mathrm{Na}$ obra escolhida, observamos que este indivíduo que viveu a catástrofe e se transformou na "catástrofe do sujeito", isto é, em um sobrevivente que carrega em si a catástrofe histórica subjetivada em sua singularidade individual, representa literariamente esta situação precária em um romance testemunhal cuja estrutura explicita tal precariedade como processo dialógico-dialético fragmentário.

A história do protagonista de La escritura o la vida representa um processo dialético negativo: a identidade do sobrevivente testemunha escritor se reconstrói através de um desenvolvimento dialético e precário sem possibilidade de conclusão. Em outras palavras, a reconstrução de sua identidade, que envolve um processo de desalienação, dá-se somente mediante a incorporação da negatividade extrema de uma cisão radical sofrida em Buchenwald transformada em elaboração literária, a qual compromete, contínua e renovadamente, sua própria identidade e existência. A elaboração desta história de transformação precária é em si uma mediação para se aproximar dos anos vividos em Buchenwald. A atividade sobre a linguagem literária se torna para este intelectual sobrevivente do Holocausto o meio de relação com o mundo, de reflexão crítica e ação combativa em face das atrocidades e dos crimes cometidos na Europa e no mundo pelos Estados totalitários e ditatoriais. Mas também poderíamos dizer que este fazer literário se converte no substrato em que o sentido do mundo, a autoreflexão e o autoconhecimento se renovam sempre em luta com o perigo iminente da dissolução do eu. Portanto, ele requer um trabalho crítico reflexivo e renovador da instância enunciadora do eu sobre a linguagem e a forma. Em La escritura o la vida, a condição precária da representação da catástrofe é objetivada na precariedade da forma.

No campo da teoria da literatura de testemunho, Valeria De Marco delineia duas linhas teóricas que procuram sistematizar o conhecimento dessa produção: uma, proveniente dos estudos do Holocausto ou da Shoah, outra, voltada às obras literárias latino-americanas. De Marco observa que tais vertentes pouco ou nada dialogam entre si como se seus objetos de estudo não mantivessem nenhuma ligação. 
Dentro da segunda corrente, a autora identifica duas acepções distintas de literatura de testemunho: a primeira, originária do Júri do Prêmio Casa das Américas de 1969, debruça-se sobre textos, cuja composição envolve diversos discursos literários, documentais ou jornalísticos, que têm como objetivo retratar a violência das ditaduras latino-americanas do século XX; a segunda, surgida na década de 1980 e alçada sobre o testemunho de Rigoberta Menchú, liga-se ao espaço acadêmico norte-americano e lança mão dos estudos culturais. Seus representantes mais expressivos são Elzbieta Sklodowska e John Beverley, e a obra que enseja sua reflexão é Biografía de un cimarrón (1966), de Miguel Barnet. Conforme De Marco, para tais autores a literatura de testemunho, formada na América Latina, tem como elemento definidor de sua forma a existência de um narrador mediador, normalmente intelectual letrado, que recolhe o testemunho da voz do "outro", pertencente às camadas marginalizadas e excluídas da sociedade, para produzir um saber que potencialmente transformaria a consciência de classe. A autora nota que tal reflexão busca estabelecer um vínculo político e solidário entre letrado e subalterno como estratégia e modo de reprodução e transmissão fiel do discurso do "outro" que se contraporia ao discurso hegemônico da História produzido pelas instâncias oficiais de poder.

Na linha de estudo da Shoah, De Marco observa que há duas tendências que se contrapõem marcadas pelo debate sobre a possibilidade ou impossibilidade da representação do horror: a primeira se nega a aceitar como legítimos os testemunhos de pessoas que não passaram pelos campos de concentração e advoga a impossibilidade de dar-Ihes uma forma estética; a segunda amplia seu corpus a produções alheias aos sobreviventes e admite a representação estética do evento, inclusive como necessária, não obstante suas limitações irrefutáveis e desejáveis para que não se incorra na estetização do mal.

A hipótese formulada por De Marco em relação à ausência de interlocução entre as duas grandes linhas teóricas é de que o discurso das correntes teóricas voltadas à literatura de testemunho latino-americana procura resguardar a canonização do gênero territorialmente a fim de estabelecer uma identidade cultural, reforçada por um campo do saber (o literário), em benefício de uma 
prática revolucionária oficial e supostamente libertária, encabeçada pelo governo de Cuba. Conforme a autora, o problema de tais correntes consiste em pretender normatizar uma forma literária que não "se submete docilmente a moldes" e em defender o caráter democratizante dessa literatura, silenciando para a complexidade do aparelho estatal moderno enquanto produtor de exclusões não homogêneas, de direita e de esquerda. Para De Marco, dizer que a literatura de testemunho é capaz de despertar as consciências oprimidas ou produzir uma inclusão social significa desconsiderar o processo histórico de exclusão social e política que define o Estado moderno neste século. Segundo a autora, A "era da catástrofe", como a chama Hobsbawn, caracteriza-se pela violência, pela barbárie, pela fabricação de uma zona de exclusão que constitui o campo de sustentação e atuação do Estado. Em sua acepção, as produções literárias de caráter testemunhal da América Latina e da Shoah são convergentes porque têm como contexto global uma geopolítica pautada na administração burocrática e racional dos esforços repressivos, baseada na indiferença moral e ética advinda deste racionalismo moderno e apoiada em um poder bélico destrutivo sem precedentes na história da humanidade.

Nossa problemática mais específica, portanto, insere-se dentro deste contorno teórico em que estas duas linhas de investigação se entrecruzam, ainda que esteja mais voltada para o evento histórico da Shoah, já que nosso autor, Jorge Semprún, é um sobrevivente do campo de concentração nazista de Buchenwald e seu romance testemunhal representa sua visão particular dessa terrível experiência histórica.

Diferentes acepções de catástrofe, representação, trauma, memória, história, testemunho e literatura fundamentam uma e outra posição sobre essa forma literária, posto que sua matéria se liga a uma experiência histórica cuja formação é palco ideológico de diferentes teorias e concepções de mundo.

Entre os que defendem a idéia de que a Shoah não é representável, como Irving Howe ${ }^{5}$, circula o entendimento de que o horror vivenciado pelos

\footnotetext{
5 HOWE, Irving. "A escrita e o holocausto" in Cadernos de língua e literatura hebraica. Fac. Filosofia Letras e Ciências Humanas/USP, n. 2, 1999, p. 11-37.
} 
sobreviventes vai além das condições psicológicas e da capacidade lingüística de compreendê-lo e transmiti-lo de modo racional e coerente. Nesta perspectiva, o mal sofrido nos campos de concentração corresponde a uma vivência cuja natureza traumática impede sua transformação em experiência comunicável. $O$ texto de Irving Howe a tal respeito nos parece clássico, pois expõe uma gama de razões para sustentar a impossibilidade de representação da Shoah que se repetem em outros textos dessa linha. Os argumentos de Howe contrários à possibilidade de representação se organizam segundo três instâncias interdependentes: a natureza da matéria, a forma literária e a testemunha como ficcionista.

Conforme Howe, o Holocausto enquanto evento histórico resiste a um tratamento científico e literário, já que extrapola as categorias e estruturas racionais tanto científicas como estéticas "habilitadas" a dar conta dos problemas que nos apresenta. Partindo da premissa de que as estruturas literárias tomam como substrato e modelo os "arquétipos atemporais da experiência humana", o autor ressalta a impossibilidade de se adequar qualquer modelo arquetípico à seqüência, segundo ele, ilógica e improvável de eventos ocorrida no Holocausto. Para Howe, a situação do extermínio, da "Solução Final", não cabe em nenhuma estrutura romanesca, posto que, segundo sua visão, o material não se dobra a esquemas éticos aos quais se subordinariam arranjos estéticos. Howe sublinha o fato de o Holocausto representar um problema ético sem resposta e sem precedentes na história da humanidade. Desta perspectiva central, o autor analisa a decorrência de outro problema: a contradição entre o realismo dos fatos históricos vivenciados pelos sobreviventes narradores e os moldes simbólicos, mitológicos e metafóricos dos quais se serviriam estes narradores para configurar sua experiência. Este parece ser o ponto a partir do qual seu argumento se desenvolve. Howe afirma que a obrigação moral de o narrador testemunha ser fiel à realidade vivenciada não Ihe permite transformá-la, dotá-la de uma elaboração estética com a qual o material bruto ganharia a autonomia e a liberdade da conduta humana representadas na narrativa de ficção do mundo ocidental. Em 
outras palavras, o universo concentracionário não contém o elemento contingente, destacado por Lukács, tão caro ao desenvolvimento da personagem no romance, para a problematização da relação conflituosa entre o herói e seu mundo.

Como exemplo do que observa Valeria De Marco a respeito dos intelectuais desta linha teórica e crítica, Howe cita as frases de Theodor W. Adorno ("Escrever um poema é barbárie depois de Auschwitz") e de Primo Levi ("Nos tornamos cientes que nossa linguagem tem falta de palavras para expressar esta ofensa, a demolição do homem") como fundamentação teórica e constatação empírica de seu argumento. Para o autor, a testemunha e a própria crítica ao tratar do tema não podem escapar dos limites insuperáveis da linguagem, mesmo a literária, e de suas imposições e proibições éticas. O autor lê na frase de Adorno uma advertência à fruição que se possa experimentar através da estetização do horror, um chamado ao silêncio que se deve acolher com relação ao inominável deste horror, uma objeção à tendência humana a desejar explicar, atribuir sentido simbólico, proporcionar catarse e reconciliar-se com o irreconciliável. A partir da frase de Adorno, Howe também ensaia sobre o caráter impenetrável desta experiência, supondo que o filósofo, em suas reflexões sobre a relação da literatura com o Holocausto, aproximava-se de uma zona entrevista pelos mitos, a do sublime tornado abjeto absoluto, inapreensível pelo olhar e improferível: a "essência dos tabus" de Freud.

Quanto ao narrador testemunha, Howe sustenta sua condição desfavorável como romancista ou ficcionista. Para tanto, ele comenta alguns exemplos de fiç̧ão do Holocausto que, em sua apreciação, comprovam o indubitável malogro do empreendimento. Na perspectiva do autor, tais textos acenam para as barreiras irrevogáveis e incontornáveis àquele escritor que se arrisque a tomar o tema como matéria ficcional. Neste sentido, para Howe, o sensacionalismo da dor, a "banalização do mal" (Hannah Arendt), as respostas contundentes e exaltadas ao Holocausto, o realismo cru e direto como representação dos acontecimentos, a aproximação aos arquétipos literários, a tentativa de simbolização do horror, a catarse ou o perigo de se extrair prazer estético do evento são resultados indesejáveis e riscos que a tentativa de representação de Auschwitz corre. Os 
testemunhos de Chaim Kaplan, Elie Wiesel, Filip Muller, Primo Levi, David Rousset, Eugen Kogon, Borowski, e Jorge Semprún (A longa viagem) são analisados como evidências do fracasso da empresa literária do testemunho do Holocausto. Ao final, Aharon Appelfeld e Pierre Gascar são incluídos como exemplos "das poucas obras-primas da ficção do holocausto" nas quais, segundo o autor, o que "não se pode" impõe o que "não se deve": não se pode (e não se deve), por exemplo, fazer "relatos de torturas ou retratos de campos de concentração ou imagens de câmaras de gás". Como outros autores desta linha, o que o discurso de Howe faz é derivar uma sentença proibitiva para a representação literária do Holocausto da advertência de Adorno sobre os perigos da "banalização do mal", do tratamento acrítico e da insensibilização ao tratar de Auschwitz como matéria estética que incorra na forma do entretenimento ou da fácil catarse e do trivial consolo. De modo que ele se aproxima de uma normatização do que "se deve" realizar e apreciar nesta literatura em função do que "não se deve" e toma os problemas de caráter ético como dados impeditivos estéticos. De certa maneira, o autor confunde a representação que problematiza os limites e as dificuldades pelos quais passa a testemunha para elaborar sua experiência em forma literária com as advertências críticas quanto à possibilidade de não se alcançar esta forma estética problematizada e confunde estas advertências críticas com a sanção proibitiva de uma representação estética da experiência do limite. Howe propõe que se deve evocar, invocar, sugerir, silenciar, deixar em suspenso, incompleto, reticente... o que não se pode dizer. ${ }^{6}$ As dificuldades, contidas nos enunciados dos relatos testemunhais literários, de encontrar uma forma de expressão "justa", uma perspectiva "equilibrada", para tratar do tema parecem corroborar a teoria da impossibilidade de representação do Holocausto.

\footnotetext{
${ }^{6} \mathrm{O}$ que "se deve" para Irving Howe é o que notamos ocorrer na literatura do Holocausto. Howe explica que $A$ longa viagem de Jorge Semprún demonstra as dificuldades do romancista para adequar o conteúdo do horror à forma ao empregar flashbachs como uma tentativa de estender o tempo da narrativa, segundo ele, "essencial para obras de ficção imaginativa". Podemos lembrar, no entanto, de Entre atos de Virginia Woolf ou ainda de Ulisses de James Joyce, romances repletos de flashbachs, em que o tempo dos acontecimentos, narrado como presente fictício, não ultrapassa o período de um dia. Muitas vezes, o romance moderno desloca os modelos arquetípicos literários e esgarça de tal maneira o tempo e os elementos narrativos que alguns romances oriundos de testemunhas do Holocausto nos parecem convencionais quanto à forma romanesca contemporânea.
} 
Uma reflexão bastante distinta da de Howe é a de Aharon Appelfeld. ${ }^{7}$ Enquanto escritor testemunha, ele analisa os sentimentos contraditórios e a situação precária da testemunha na sua relação com a memória e na sua difícil integração na sociedade de pós-guerra em suas diferentes fases conforme os momentos e contextos históricos de um período por ele delineado. Appelfeld descreve que, primeiro, no campo de concentração, contar a experiência se tornou um estímulo e uma missão de sobrevivência para os prisioneiros. Mas que, uma vez libertos, eles se debateram com a vontade de contar e o desejo de esquecer, com a vontade de esquecer e sua impossibilidade. Segundo o escritor sobrevivente, o mundo de pós-guerra, por outro lado, tendia a uma postura de não querer ouvir, de soterrar a memória da dor, de neutralizá-la com o esquecimento, o entretenimento e a ausência de reflexão. Appelfeld observa que ao encarar a escrita como meio de materializar sua vontade e necessidade de contar, a testemunha tinha a sensação renovada de impotência, de que a experiência não podia ser contada e elaborada ou ainda de que as convenções e as fórmulas artísticas, na medida em que se associam ao belo, desmentiam o sofrimento infligido às vítimas. $O$ escritor acrescenta que muitas testemunhas padeceram a "síndrome de culpa" por haver sobrevivido quando muitos companheiros naufragaram.

Appelfeld interpreta estes sentimentos e desejos contraditórios do sobrevivente como momentos de um processo psicológico e ideológico, individual e coletivo, um período de negação que a própria economia psíquica e o princípio de autoconservação demandaram, mas que encontraria em seu devir uma nova perspectiva adequada à "consciência artística". Appelfeld, à semelhança de Giorgio Agamben ${ }^{8}$, adverte quanto ao perigo de se revestir o Holocausto de uma aura mística, de confundi-lo com o insano, o incompreensível, o misterioso e sem significado que acarreta o obscurecimento da catástrofe enquanto genocídio de

\footnotetext{
7 APPELFELD, Aharon. "Depois do Holocausto" in Cadernos de Língua e Literatura Hebraica. Fac. Filosofia Letras e Ciências Humanas/USP, n. 2, 1999, p. 81-91.

${ }^{8}$ AGAMBEN, Giorgio. Lo que queda de Auschwitz. El archivo y el testigo. Homo Sacer III. Trad. Antonio Gimeno Cuspinera. Valencia: Pre-Textos, 2000.
} 
Estado. ${ }^{9}$ Para o escritor, a literatura e a arte em geral podem "humanizar" o Holocausto, dimensioná-lo dentro da compreensão humana sem fugir à sua complexidade.

Os valores e o sistema moral que orientavam a conduta do sobrevivente desnudam-se em sua ineficácia e falsidade enquanto ideologia da sociedade burguesa edificada no mundo ocidental. A perda da crença no mundo, nas instituições representantes do estado de direito formal, ou ainda numa ordem alternativa a esta como a do socialismo real, invade tanto o sobrevivente que permaneceu no capitalismo ocidental, muitas vezes refugiado em outros países, como aquele que voltou aos países submetidos ao regime totalitário soviético.

A situação e a condição do sobrevivente do Holocausto, dos Gulags do regime soviético, dos torturados pelos aparelhos repressivos dos Estados ditatoriais no terceiro mundo, enfim de catástrofes históricas de nosso século $\mathrm{xx}$, estão marcadas pela ação violenta do Estado moderno. Este Estado é fundamentado por uma lógica objetiva, burocrática e racional, sobretudo do ponto de vista da ratio de dominação, e traz elementos de negatividade absoluta que revelam a perplexidade, a irracionalidade, o grau de monstruosidade e de reificação que alcançou nossa organização social.

Ao analisar a literatura de testemunho, Jeanne Marie Gagnebin ${ }^{10}$ comenta que as dificuldades por que passa a testemunha da Shoah em rememorar, elaborar e enfrentar os traumas desta experiência terrível constituem não só o paradoxo de sua matéria, mas também sua "especificidade dolorosa". A autora reflete sobre a dialética da singularidade da Shoah e da semelhança a outros genocídios da civilização moderna, insiste na importância de uma memória do passado construída no e pelo presente a serviço do desmascaramento e do enfrentamento dos assassínios de Estado praticados agora. Quanto à questão da representação do mal, Gagnebin afirma que a escrita literária particularmente

\footnotetext{
${ }^{9}$ Estima-se que 18 milhões de pessoas foram aniquiladas no Holocausto. Aproximadamente um contingente humano de 6 milhões de judeus e um contingente de 12 milhões composto por prisioneiros políticos, ciganos, homossexuais, opositores ao nazismo e às ordens de Hitler, testemunhas de Jeová, criminosos comuns, portadores de defíciência física, etc.

${ }^{10}$ GAGNEBIN, Jeanne Marie. "Palavras para Hurbinek" in NESTROVSKI, Arthur e SELIGMANNSILVA, Marcio (orgs). Catástrofe e representação. São Paulo: Escuta, 2000, p. 99-110.
} 
constitui o "veículo privilegiado de transmissão dessas experiências do horror", porque se define como um "testemunho indireto, mediado pela busca, tão essencial quanto irrisória, das palavras justas". A autora entende assim as dificuldades de representação na literatura da Shoah como um problema paradoxal que "habita, sustenta e solapa simultaneamente" essa forma literária.

Em "Palavras para Hurbinek", Gagnebin comenta que no colóquio de 1997, em Paris, intitulado "O homem, a língua, os campos", os participantes especialistas em literatura reconheceram a presença nos textos da literatura de testemunho de "uma dialética da falta e do excesso que se desdobra numa retórica do indizível - característica, aliás, próprias da literatura moderna e levadas à sua singular exacerbação pela literatura dos campos". ${ }^{11}$

Em "Campo francês: Max Aub y la literatura de testimonio" ${ }^{12}$, De Marco aproxima a literatura de testemunho à estrutura irônica (Frye), mostrando que composições como a do romance Campo francés de Aub se distanciam da tradição literária e colocam à crítica, de maneira radical, a ruptura da cadeia associativa entre língua, nação e tradição literária. Na perspectiva da autora, a tensão entre ética e estética, entre a necessidade de contar sendo fiel à verdade e a dificuldade de elaborar enfrentando os fantasmas da dor do trauma, caracteriza a literatura de testemunho:

"Como las atrocidades de nuestra época destruyeron la creencia en la razón y la omnipotencia de la explicación, el testigo debe relatar lo que ha visto sin usufruir de la distancia tranquilizadora típica de la narrativa, ya que su vivencia escapa a la comprensión, al estar marcada por el movimiento del trauma: sucesivas aproximaciones a través de la evocación y de la narración cuya expresión adecuada siempre se posterga. Escribir es convivir con la mudez, es compartir con el lector un discurso que es resistencia al olvido, al aislamiento, al silencio y a la muerte. Por eso el testigo tiene que enfrentarse con las relaciones entre lenguaje y violencia, la necesidad de decir lo indecible, como insiste Levi. En su búsqueda de representar el horror, el escritor se plantea la necesidad de reproducir la paradoja entre el instante de la materia narrada y el carácter perenne del lenguaje, la contradicción entre ambigüedad y literalidad, la tensión entre la poesía de la inmediatez y el

\footnotetext{
${ }^{11}$ Idem Ibdem, p. 99-110, (o itálico é nosso).

12 DE MARCO, Valeria. "Campo francés: Max Aub y la literatura de testimonio" in Quaderni di Dipartimento di Lingüística. Serie Letteratura 9 Rende, v. 21, 2002, p. 55-68.
} 
estilo del exceso de realidad, la reducción del espacio de la imaginación y la escasez de la sintaxis explicativa." ${ }^{13}$

Concebemos, pois, que a "representação do horror" significa um elemento dialético negativo constitutivo da representação da realidade na literatura de testemunho. A impossibilidade de expressar o centro do horror, em virtude de o verdadeiro horror ter sido experimentado por aqueles que foram aniquilados ou pelo muçulmano, aquele que viu a Gorgona, a face que representa a impossibilidade de ver, é uma aporia de Auschwitz pensada por Agamben para explicar a "testemunha integral". O filósofo descreve-a como um vazio, uma lacuna, presente nos testemunhos em forma de um silêncio significativo que, contudo, deve ser interpretado e não reverenciado sob pena de mistificá-lo e obliterá-lo, obedecendo à vontade perversa dos nazistas de apagar os vestígios das atrocidades relatadas pelas vítimas sobreviventes.

Para Giorgio Agamben ${ }^{14}$, o testemunho nasce de uma impossibilidade de testemunhar. O pensamento dialético deste filósofo político recupera a noção de "vida nua", cuja primeira acepção surge em Aristóteles, contextualizando-a no âmbito do Estado moderno a partir do pensamento de Michel Foucault e Walter Benjamin. A complexidade da expressão "vida nua" concerne à articulação entre a esfera do poder soberano e a vida não qualificada (politicamente). Este nexo paradoxal tem como fundamento o poder soberano do Estado moderno que se assenta na exclusão inclusiva da vida nua, porque é em forma de exceção que ela se torna regra. O sujeito do testemunho, reduzido a uma vida não qualificável politicamente, está, assim, constitutivamente cindido e sua substância é composta por uma dialética entre vivente e falante, não-homem e homem, dessubjetivação e subjetivação, mulçumano (a testemunha integral) e a testemunha sobrevivente. Lugar não definível, o testemunho se dá em um território onde uma intimidade indivisível representa a potência de dizer que adquire realidade mediante uma impotência de dizer; representa a possibilidade de testemunhar implicada em sua impossibilidade. Tais movimentos, conforme o pensador, não se identificam em

\footnotetext{
${ }^{13}$ Idem Ibdem, p. 57.

${ }^{14}$ AGAMBEN, op. cit.
} 
uma consciência, mas se evidenciam em um discurso lacunar e fragmentário que os configura.

Pensamos que na literatura de testemunho as dificuldades e os limites da representação do mal se dão como representação dos limites e da impotência da linguagem para dar conta da história da precariedade do sujeito que vivenciou a catástrofe. A testemunha narrador, na sua relação com a linguagem, encontra-se numa luta para dominá-la, pois a situação de total passividade na dor e na humilhação, de total privação de autonomia e domínio sobre o futuro, vivenciada nos campos de concentração e em outros espaços de vida nua, enfim, a denominada dessubjetivação de Agamben não é idêntica à hora de narrá-la. Podemos perceber como em algumas obras da literatura de testemunho ocorre um processo de ressubjetivação através da busca de domínio sobre a escrita e de restauração de sentido, que implica uma elaboração da história de dessubjetivação do narrador testemunha como momento dialético negativo deste processo. O que está em jogo é a reconstrução de uma identidade que se viu desfeita, de uma pessoa que passou pela desintegração da personalidade, através de uma escrita que nega esta reconstrução enquanto bildung, pois a percebe como falácia da ideologia do mundo burguês que a qualquer momento, por meio da ação violenta de seu órgão cerebral, o Estado, pode destruí-la. ${ }^{15} \mathrm{Se}$, conforme Agamben, o testemunho nasce dialeticamente da impossibilidade de testemunhar, e não apesar dela ou paralisando-se por sua resistência bloqueadora, é porque a falta instaura a sua criação. Os limites do testemunho do horror, que ocupam suas lacunas, manifestam-se nas obras de cunho literário como forma de representação dos limites. A necessidade de relatar não se opõe de modo absoluto à impossibilidade de representar. Sua relação é dialética na medida em que a dessubjetivação da testemunha sobrevivente aparece e determina, na sua relação individual e histórica com o mundo que the impôs tal alienação radical, uma resposta negativa, a da ressubjetivação através da

\footnotetext{
${ }^{15}$ Imre Kertész é um escritor sobrevivente que reivindica a reconstrução de sua identidade pela escrita: “¿No esperáis de mí que formule mi pertenencia nacional, religiosa y racial? No esperáis de mí que tenga una... identidad? Os lo revelaré: sólo poseo una identidad, la identidad del escribir. (Ein sich selbst schreibende Identität.) Una identidad que se escribe a si misma." In KERTÉSZ, Imre. Yo, otro. Crónica del cambio. Trad. Adan Kovacsics. Barcelona: Acantilado, 2002, p.63.
} 
elaboração escrita dessa dessubjetivação. A compreensão e a atribuição de sentido à experiência pessoal de dessubjetivação catastrófica às vezes se materializam nesta modalidade literária mediante um processo de ressubjetivação. $\mathrm{Na}$ obra que analisamos, é através da rememoração de seu processo de dessubjetivação que a testemunha reconstrói sua subjetividade perdida. Esta reconstrução literária, em La escritura o la vida, é decorrente de um trabalho inclusivo da dessubjetivação nos termos dialéticos de uma ressubjetivação da dessubjetivação, ou seja, da negação da negatividade do campo, assumindo esta negatividade. As estratégias do testemunho literário para lidar com este processo histórico de objetivação da perda da subjetividade da testemunha na forma narrativa literária são múltiplas. Estamos tratando de um objeto de estudo que, diferentemente da tragédia, aponta para uma desestabilização definitiva da harmonia do sujeito e de sua relação com o meio. A identidade do sujeito, sua confiança no mundo, seus parâmetros sociais, seus referenciais éticos, a utopia, enfim, sofrem um abalo sem possibilidade de recomposição de modo que o que sobra (para narrar) são perdas, fissuras, tentativas de reintegração fracassadas em forma de uma reconstrução da subjetividade mediante a experiência negativa desta. É o fim da épica segundo se discute no texto "O narrador" de Walter Benjamin.

O emprego do termo "precário" ou "precariedade" consiste numa estratégia de nossa tese que se mostra produtiva para a definição de nosso objeto. Como significados possíveis da palavra, temos: 1) difícil, minguado, estreito; 2) escasso, raro, pouco, insuficiente; 3) incerto, vário, contingente, inconsistente; 4) pouco durável, insustentável; 5) delicado, débil. A etimologia da palavra nos remete a precarius, do latim, "obtido por meio de prece; dado por complacência"; ou temporário, instável, aquilo que não é definitivo, portanto passageiro, provisório; ou ainda, difícil, escasso, insuficiente. ${ }^{16}$

$O$ adjetivo difícil refere-se, por exemplo, ao modo penoso, intrincado, obscuro que o trauma vivenciado pelo "sujeito da catástrofe" tornou sua

\footnotetext{
${ }^{16}$ FERREIRA, Aurélio Buarque de Holanda (Ed.). Novo dicionário da língua portuguesa. Rio de Janeiro: Nova Fronteira, 1986.
} 
representação desta experiência. O trauma, enquanto evento que excede a capacidade de a mente assimilá-lo, dificulta sua elaboração mimética. Este, então, retorna à memória em forma de possessão repetitiva, literal e não passível de simbolização. Neste sentido, a razão e a elaboração estética são postas em dúvida por uma reflexão teórica que indaga a possibilidade de se representar a catástrofe, ao menos nos termos da tradição racionalista realista, ao mesmo tempo em que reconhece o imperativo ético e terapêutico que mobiliza a sua representação. O pressuposto é defendido por Márcio Seligmann-Silva ${ }^{17}$.

O indizível, a fragmentação, a inapreensão do evento traumático, os cacos não harmônicos da memória, a estética do abjeto como inversão à do sublime, a literalidade bruta, a sugestão, a incompletude de significado, a irresolução de sentido, a ausência de trama, as incertezas do pensamento, as imagens inacessíveis à interpretação são elementos trazidos à baila por teóricos do testemunho, como Arthur Nestrovski ${ }^{18}$, na investigação desta forma literária.

A idéia de escasso, pouco, insuficiente, relativa à de dificuldade de expressão, reporta ao silêncio, ao lacunar, à privação da palavra, à interrupção, ao corte do discurso. Marcas da impotência da voz da testemunha, seladas em sua narração. A debilidade, a fraqueza, a inconsistência da linguagem redundam em frases reticentes, em um tom melancólico, em um estilo esparso e elíptico, identificado por Geoffrey Hartman ${ }^{19}$.

A questão da debilidade coaduna com uma doença incurável, uma experiência da morte. A doença do trauma, por natureza subterrânea, deve-se à opressão política sofrida pelo sobrevivente em forma de violência excessiva. A testemunha, assim, é relegada às camadas inferiores da sociedade, ao seu inframundo e, internamente, sente-se um ser ínfimo, abjeto, auto-rebaixado. A crise do sujeito acometido por uma doença incurável impele-o a um testemunho precoce que se dá sob uma prática discursiva incompleta, em permanente crise, inconsciente, acidental, imprevisível. A palavra, levada ao colapso, subverte

\footnotetext{
${ }^{17}$ SELIGMANN-SILVA, Márcio. "A história como trauma" in NESTROVSKI, Arthur e SELIGMANNSILVA, Marcio (orgs), op. cit., p. 73-99.

${ }^{18}$ NESTROVSKI, Arthur. "Vozes de criança", Ibdem, p. 185-205.

${ }^{19}$ HARTMAN, Geoffrey. "Holocausto, testemunho, arte e trauma". Ibdem, p. 207-235.
} 
imagens míticas e causa surpresa, estranhamento, incerteza, no leitor. O transitório, o passageiro, o efêmero se expressam como algo que de súbito fenece antes de alcançar seu apogeu, sua plenitude. Tais acepções, de Shoshana Felman ${ }^{20}$, solidarizam-se com a noção de provisório advinda de precário.

O temporário encontra outros ecos na problematização efetuada por Valeria De Marco $^{21}$ da relação entre o escritor do século xx e sua língua: em um mundo em que a violência de Estado exclui o sujeito da vida social e política, o que the resta é um estar no mundo em permanente desabrigo, que se estende para sua relação com a língua. Segundo a autora, o fenômeno do apátrida nesse século designado como a "era do refugiado" por Said e caracterizado pelos "refugiados como fenômeno de massa" por Giogio Agamben -faz-se notar mediante uma ruptura na tradição literária nacional e uma fissura na interlocução. $O$ apátrida não se sente mais à vontade em sua língua materna, sofre um estranhamento. O seu mal-estar no mundo leva-o a um deslocamento constante que torna sua relação com a língua e com o meio cultural e social em que se encontra frágil e provisória.

A obra de Jorge Semprún, em geral, e aquela referente ao chamado ciclo de Buchenwald, em particular, - Le Grand Voyage (1963), L'Évanouissement (1967), Quel beau dimanche! (1980), L'Écriture ou la Vie (1994), Le mort qu'il faut (2001) - apresentam diferenças interpretativas quanto à sua classificação que apontam para a presença de uma estrutura aberta em sua composição. Se esses romances compõem-se, por um lado, de elementos autobiográficos, testemunhais e memorialísticos, por outro se inscrevem em um modo de representação próprio da ficção contemporânea. Estas obras articulam procedimentos como a fragmentação textual e discursiva, o jogo de planos temporais distintos, a pluralidade de perspectivas, a simbolização do espaço referencial, o recurso à intertextualidade e à metalinguagem, a justaposição e o desdobramento das identidades de personagens e narradores, a pluridimensionalidade do enredo, o entrecruzamento das ações, a incorporação de técnicas cinematográficas como o crossing-up, do nouveau roman e do romance policial, entre outros. No caso desta

\footnotetext{
${ }^{20}$ FELMAN, Shoshana. "Educação e crise, ou as vicissitudes do ensino" in Pulsional. Revista de Psicanálise. Ano XI e XII, n. 116-117, dezembro 1998/janeiro 1999, p. 9-48.

${ }^{21}$ DE MARCO, Valeria. Op. cit.
} 
matéria, tais técnicas geram uma tensão entre o discurso referencial da narrativa não literária e o discurso figurado e ambíguo da ficção. Semprún rei(vindica) uma versão dos fatos históricos, entre as práticas discursivas legitimadas para produzir a verdade sobre a realidade histórico-social, através do discurso literário e das formas da prosa de ficção.

Esta contradição entre história e literatura, realidade e ficção, que permeia os textos literários de caráter testemunhal, faz-se bastante patente na obra de Semprún. Os críticos que se dedicam a ela, conforme suas tendências teóricas e seus objetivos analíticos, só tornam mais evidente esta "abertura" contraditória de seu fazer literário ao produzirem interpretações diferentes entre si.

Angel G. Loureiro ${ }^{22}$, por exemplo, coloca La escritura o la vida ao lado de Adieu, vive clarté (1998) como "relatos autobiográficos paradigmáticos". Tendo, em seu ensaio, Adieu, vive clarté como a obra principal de sua análise crítica, seu olhar está mais voltado para o tema do estranhamento e do desenraizamento, segundo o autor, dominante nas obras de Semprún. Loureiro procura defender um novo paradigma teórico do gênero autobiográfico, apoiado na noção de sujeito da filosofia de Levinas, na qual o sujeito não é substancial senão constituído a partir da ética e da responsabilidade para com o outro. Assim, o autor demonstra estar preocupado com o tipo de identidade que é elaborada em narrativas como $\mathrm{La}$ escritura o la vida que corroboram sua visão crítica sobre o cânone moderno da autobiografia.

O texto de Ofelia Ferrán, "El largo viaje del exilio: Jorge Semprún" ${ }^{23}$, publicado em 1995 - data em que Le mort qu'il faut ainda não existia - considera as quatro primeiras obras citadas anteriormente romances. A condição existencial do exílio permanente dos sobreviventes dos campos de concentração e suas várias facetas semânticas manifestas nas configurações narrativas da obra de Semprún constituem o objeto de seu ensaio.

\footnotetext{
${ }^{22}$ LOUREIRO, Angel G.. "Semprún: Memorial de ausencias" in Cuadernos Hispanoamericanos, n. 617, Nov 2001, p. 21-29.

${ }^{23}$ FERRÁN, Ofelia. "'El largo viaje' del exilio: Jorge Semprún” in SOLER, Manuel Aznar (ed.) El exilio literario español de 1939. V. 2, Serpa Pinto. 1. Barcelona, Spain: Grup d'Estudis de l'Exili Literari, Departament de Filologia Espanyola, Universitat Autònoma de Barcelona (GEXEL), 1998, p. 107-15.
} 
Felipe Nieto, em seu texto 'La 'resurrección' de Jorge Semprún: el regreso de Buchenwald" ${ }^{24}$, prioriza a função do termo "aparecido", ressuscitado, para a estratégia de "sobrevida", de continuidade da sobrevivência do ex-prisioneiro de Buchenwald e para a escrita memorialística desenvolvida pelo escritor. De modo que La escritura o la vida assim como El largo viaje entram na chave classificatória de narrativas memorialísticas, segundo o autor, modo de representação da experiência vivida em Buchenwald eleito e singularizado por Semprún, que permite a reconstrução contínua da sobrevivência por intermédio da rememoração na escrita.

Raúl Illescas ${ }^{25}$, por exemplo, sublinha o elemento ensaístico como definidor do gênero a que pertence La escritura o la vida. Mas tal classificação não fica clara, a princípio, com a observação de que a obra "constituye junto con otras novelas de este autor, el testimonio español de la matanza sistemática y organizada por el nazismo" e de que

“la lectura de la novela de Semprún propone más de una entrada para su
análisis. En principio, el estatuto discutible de novela que el autor le
asigna. En segundo término, el lugar del 'aparecido', la condición que se
atribuye el narrador para poder exponer los hechos acaecidos en ese
campo de concentración y en su vida posterior. Y en tercer lugar la
presencia de la literatura. (...) Escritores, poetas y pensadores que le
permiten una reflexión no sólo sobre su estadía en Buchenwald sino
también sobre la posibilidad y el modo de narrar el holocausto." ${ }^{26}$

Sua análise concentra-se no terceiro aspecto. Mas o relevante de sua abordagem introdutória é justamente o fato de mencionar que as três entradas interpretativas do texto resultem de uma proposta decorrente de seu próprio modo de organização e estruturação, o que o aproxima da noção de "obra aberta", conforme desenvolvida por Umberto Eco. Daí a aparente contradição lógica de Illescas ao chamá-lo de romance e ao mesmo tempo questionar seu estatuto de romance.

\footnotetext{
${ }^{24}$ NIETO, Felipe. "La 'resurrección' de Jorge Semprún: El regreso de Buchenwald" in Revista de Occidente, n. 266-67, Julio-Agosto 2003, p. 205-15.

${ }^{25}$ ILLESCAS, Raúl. "Jorge Semprún: La escritura o la vida. Holocausto y literatura" in LEMER, Isaías (ed.) NIVAL, Robert (ed.) ALONSO, Alejandro (ed.) Actas del XIV Congreso de la Asociación Internacional de Hispanistas, III: Literatura española, siglos XVIII - XX. Newark, DE: Cuesta, 2004, p. 31522.

${ }^{26}$ ILLESCAS, Raúl. Ibidem, p. 315.
} 
O texto de Txetxu Aguado ${ }^{27}$ trata o romance La escritura o la vida como um livro que materializa o projeto político de Semprún de interagir na sociedade evitando futuros campos de concentração e que, para tanto, propõe-se expandir, reformular e transformar o arquivo (derridiano) sobre a experiência do Holocausto, tornando-a comunicável a uma comunidade de ouvintes. A linguagem literária é vista pelo ensaísta como um meio de que se serve o escritor para inserir sua experiência do extremo em novos parâmetros que permitam pensá-la não como uma realidade excepcional. Para Aguado, o sobrevivente a usa com o objetivo de integrar-se na realidade sócio-histórica e alcançar um mundo livre de campos de concentração. Embora Aguado designe o termo "novel" para tratar do livro, ele se exime de avaliar a implicação da transformação do arquivo em linguagem literária, tratando seu objeto sempre como um livro que encarna um projeto político não obstante sua forma. Para o autor, o próprio livro significaria em si uma ação política que se realiza através da abertura do arquivo derridiano "to include experiences like his in need of a langurage and meaning". Sua perspectiva teórica coloca em segundo plano o fato literário, não somente na medida em que the parece secundário frente ao ato político que representa o livro-projeto, mas porque parte do pressuposto de que tal experiência e a memória que dela deriva não possuem tradução lingüística, não têm equivalência semântica no arquivo. Tratase de uma análise do "projeto crítico do escritor" baseada sempre no conteúdo expresso da matéria: as intenções do escritor sobrevivente e suas dificuldades de ordem psicológica. Portanto, ele tem como pressupostos teóricos a natureza inefável da experiência e defende a idéia de que a Shoah é irrepresentável. A forma que a matéria assume jamais é levada em conta a não ser como conteúdo explicitamente enunciado pelo narrador de Semprún no projeto escritural. Aguado, por exemplo, destaca a declaração do narrador de La escritura o la vida de que só o artifício literário pode aproximar-se do inverossímil da experiência. 0 instrumental teórico utilizado pelo ensaísta - o arquivo derridiano e a formulação de Habermas sobre o Estado pós-nacional - demonstra que sua reflexão é mais

\footnotetext{
${ }^{27}$ AGUADO, Txetxu. "Memory, Politics, and Post-national Citizenship in Jorge Semprún's L'Ecriture ou la vie" in Hispanic Research Journal: Iberian and Latin American Studies, v. 3, n. 6, Oct 2005, p. 237-251.
} 
voltada à filosofia política e que a literatura joga apenas um papel marginal para tal reflexão.

O texto de Valeria De Marco sobre o romance, "La escritura o la vida: la imposibilidad de ver" ${ }^{28}$, analisa sua forma para, então, estabelecer suas relações singulares com a realidade histórica à qual se refere, enquanto representação literária da mesma, e dialogar com a teoria literária e a do testemunho. De Marco considera a obra uma ficção do modo irônico, um romance "que tiene como enredo su propia composición". Traçando a relação singular presente na obra entre seu enredo e as características gerais do romance como forma épica, a autora observa que há uma "película opaca", proveniente de seu âmbito temático, "el hombre frente a la barbarie de los campos de concentración nazi", que gera o efeito de nublar a retina de seu leitor, impedindo-o de "ver el enredo lineal que vertebra el texto". Assim, falando da história que o romance narra, ela afirma que

"No se trata de la vivencia del horror; es el recorrido del narrador buscando una forma para narrarla. La barbarie emerge a través de la mediación de una secuencia de episodios que reconstituyen la historia del tormento vivido por el personaje-narrador en su trayectoria en busca de un modo para representarla." 29

Autobiografia, testemunho, memórias, ensaio, romance, ou ainda, testemunho autobiográfico ${ }^{30}$, memórias romanceadas, romance de idéias, enfim, o que nos chama a atenção é a discrepância interpretativa a que as obras de Semprún dão origem e de que La escritura o la vida não se furta. Nossa tese é que essa ambigüidade e amplitude de entradas no jogo hermenêutico que este romance oferece estão intimamente ligadas à sua estrutura dialética-dialógica fragmentária que é a objetivação formal da precariedade da matéria.

\section{O enredo dialético de La escritura o la vida}

\footnotetext{
${ }^{28}$ DE MARCO, Valeria. La escritura o la vida: la imposibilidad de ver, texto mimeografado, 2001, p. 1-32.

${ }^{29}$ Idem Ibidem, p. 1.

${ }^{30}$ Márcio Seligmann-Silva defende tal classificação. SELIGMANN-SILVA, Márcio. "O testemunho: entre a ficção e o real" in SELIGMANN-SILVA, Márcio (org.). História, Memória e Literatura - O testemunho na era das catástrofes. Campinas, SP: Editora da Unicamp, 2003, p. 371-385.
} 
Que história narra Jorge Semprún em La escritura o la vida? A de sua experiência no campo de concentração de Buchenwald ou, nos termos do narrador, a da essência dessa experiência, a da vivência da morte? A história da sua memória individual da experiência do horror de Buchenwald? Ou ainda a da sua relação enquanto sobrevivente com a memória dessa vivência ou com a escrita da memória dessa experiência? E, acrescente-se, um testemunho concebido em forma de romance, ou seja, um romance testemunhal. Em todo caso, a relação se estenderia à relação entre história e ficção. Tais recortes não são excludentes nem complementares, já que a composição dessa obra estruturase de acordo com um desenvolvimento dialético da matéria que determina sua forma precária.

A estrutura dialética desenvolvida nesta narrativa não corresponde, no entanto, a uma lógica que tem por princípio e finalidade a explicação totalizadora da experiência vivida pelo narrador. Ao contrário, esta estrutura plasma uma visão da matéria que se aproxima bastante da "dialética negativa" de Adorno cuja reflexão crítica extrai o que escapa à identidade e à totalidade das realidades e temas sobre os quais se debruça. Adorno busca toda a negatividade e os paradoxos do processo dialético da realidade histórica. Daí a precariedade e os limites da relação entre sujeito e objeto constituírem-se em elemento fundamental na construção do conhecimento para o filósofo. Podemos entrever a representação da relação precária do homem com a barbárie à qual ele sobreviveu na estrutura dialética deste enredo. Se bem o narrador pretenda com este romance proporcionar-nos uma visão de conjunto, profunda, clara e densa, do Holocausto, ou seja, oferecer-nos um meio interpretativo para conhecer a catástrofe dos campos de concentração, não é menos verdadeiro que o romance represente as carências, as insuficiências, os limites e os paradoxos desta visão. Em outras palavras: o texto abriga uma explícita intenção de ir além do relato de uma experiência particular e subjetiva de um acontecimento histórico ao mesmo tempo em que não abre mão do ponto de vista particular e subjetivo da testemunha sobrevivente do Lager. 
Para aproximar-se da essência da realidade do campo de concentração, o texto apresenta-nos a história de sua experiência posterior à libertação do campo, que se relaciona com sua memória de Buchenwald e com a escrita dessa memória. Ao contar a história da criação e realização do romance que lemos, o narrador nos faz acompanhá-lo na história de sua relação com a memória da "vivência da morte". Trata-se de um romance cujo enredo põe em perspectiva sua matéria ao narrar como a história da condição precária do sobrevivente para representá-la é fruto da negatividade desta matéria que se coloca em seu próprio perspectivismo.

La escritura o la vida é composta por três partes e dez capítulos. A narrativa inicia-se no primeiro dia após o dia de libertação do campo de Buchenwald, 12 de abril de 1945, e finda com o retorno do personagem-narrador a Buchenwald, quarenta e sete anos mais tarde, em 1992, por ocasião de uma palestra que daria a uma rede de televisão de Weimar a respeito de sua experiência no campo. As ações narradas na primeira parte do romance ocorrem dentro do campo de concentração e cobrem um curto período de tempo em que o ex-prisioneiro espera passar pelos trâmites de repatriação e experimenta os primeiros contatos com o mundo de fora do campo. Neste período, a narrativa problematiza a nova identidade transformada que surge do campo de concentração, indaga sobre a possibilidade de relatar a experiência em Buchenwald e de ser escutado pelo mundo exterior.

A segunda parte do romance, seu miolo, narra o retorno do personagemnarrador a Paris e sua estância em Ascona. Em Paris, ele sente o tormento insuportável das lembranças de Buchenwald, a impossibilidade tanto de conviver com as lembranças como de esquecê-las, ou seja, de enlutar e elaborá-las. Em Ascona, cidade em que se hospeda a fim de escrever seu testemunho literário, três meses depois da libertação, ocorre a negação da sua identidade de sobrevivente testemunha escritor mediante a tentativa de esquecer as lembranças de Buchenwald e o abandono do projeto de testemunho literário.

A terceira parte do romance conta como o personagem-narrador reencontra-se com sua identidade negada e transforma-se em narrador, ou seja, 
em sobrevivente testemunha escritor. Essa transformação ocorre em três momentos. Primeiro o eu passado invade seus escritos, em 1987, no dia da morte de Primo Levi. O segundo momento, anterior ao primeiro na cronologia, corresponde à entrega do prêmio Formentor ao personagem-narrador pela publicação de El largo viaje. Este momento é relacionado com sua expulsão do PCE e com sua atividade de leitor, principalmente de Kafka. O terceiro momento refere-se ao retorno do personagem-narrador a Buchenwald para dar uma entrevista sobre sua experiência do campo. Neste retorno ao campo, quarenta e sete anos depois, ele obtém uma revelação a respeito de sua sobrevivência que muda sua visão da experiência do Holocausto, portanto, de sua identidade e da matéria. O personagem-narrador descobre que à entrada no campo fora registrado como rebocador de paredes e não como estudante de filosofia, conforme tinha informado na ocasião ao prisioneiro que o fichara. $O$ reencontro com o eu passado é fruto de uma transformação da relação do personagemnarrador com a memória de Buchenwald e acarreta uma transformação na sua compreensão da experiência, em si mesmo e no projeto do romance.

Começar pelo fim e retornar ao início, ao campo de Buchenwald, sugere uma volta à origem, a noção de eterno retorno. O tempo do campo de concentração no texto parece que não finda, porque perdura nos sentidos, nos sentimentos, na memória do narrador de forma indelével. A narrativa parece desenhar uma circularidade inexorável, através da repetição e de um ritmo lento e pesado. Durante o romance, o narrador questiona o regresso concreto à vida "normal" em liberdade e ao mundo "civilizado" mediante alguns recursos expressivos como o uso do termo ressuscitado no lugar de sobrevivente, o espaço de Buchenwald como a pátria-origem e o mundo como lugar de eterno exílio. Tais recursos reforçam a idéia de que seu testemunho quer informar que não há retorno para quem esteve nos campos de concentração, que a catástrofe significa uma perda irrecuperável e que não há futuro para os sobreviventes. A transformação sofrida pelo sobrevivente no campo parece insuperável. Neste caso, buscar o sentido da experiência do campo através da história posterior do sobrevivente a ele significaria mostrar como não há mais história nem futuro, como não é mais 
possível haver transformação a ser narrada. Assim, o tempo dos acontecimentos narrados não conformaria um novo enredo que iluminasse a busca de sentido do passado ou conformaria sua negação na medida em que não há um novo enredo. Este de fato é um dos sentidos dialéticos que concorrem para a representação do que o narrador nomeia a vivência da morte. Porém, La escritura o la vida busca representar a essência do horror de Buchenwald através da narrativa de uma história posterior, a da relação do sobrevivente com a memória dessa experiência mediante sua relação com a escrita dessa memória. Nessa nova história, o personagem-narrador passa por uma nova transformação. Se a experiência no campo de Buchenwald havia transformado sua vida, definindo a singularidade de sua identidade, essa transformação encontra-se numa duração temporal não coberta pelo tempo ficcional do romance. A experiência de Buchenwald é rememorada através de analepses e de prolepses de analepses, de modo fragmentado, em meio à narração dos episódios centrais de cada capítulo do romance, que formam um novo enredo. A história de La escritura o la vida representa essa transformação originária do campo posta em perspectiva, ou seja, abordada mediante a narração da história de uma segunda transformação: a da relação do narrador com a escrita da memória de Buchenwald, com a negatividade do campo.

O personagem-narrador parte da necessidade e do desejo de ser testemunha escritor, passa por sua negação por não poder assumir as lembranças do campo e depois consegue uma relativa auto-realização, transformando-se em sobrevivente testemunha escritor do Holocausto. Porém, essa condição obriga-o a um enfrentamento permanente com o trauma de Buchenwald, assumindo sua ação negativa a cada momento de seu fazer literário. A superação desta alienação radical que a experiência do campo engendrou implica uma transformação da relação do personagem-narrador com a memória de Buchenwald. Mas ao passar a escrever sobre sua experiência, ele vive um processo permanente e provisório de superação desta alienação originária por meio da elaboração que a atividade literária envolve. O personagem-narrador passa a lutar contra a mesma através de sua assunção negativa na atividade literária. Para o sobrevivente, abraçar a 
vivência da morte significa o perigo de dissolução da individualidade e da vida, uma alienação terrível. A auto-realização através da escrita da memória dessa experiência implica, pois, ou uma impossibilidade inapelável ou um esforço permanente de superação, de auto-afirmação da vida e da identidade mediante a assunção dessa alienação mortífera. É esse o sentido dialético negativo do título La escritura o la vida, que a princípio se intitularia La escritura o la muerte, expressão que comprova a negatividade dialética como movimento da escrita.

A trajetória percorrida pelo personagem-narrador nesta história desenha, pois, uma espiral: não se trata simples e somente do eterno retorno ou da negação de existir regresso. Nesse romance testemunhal, a aporia de haver ou não possibilidade de volta ao mundo exterior livre para aquele que vivenciou o horror dos campos deve ser entendida em seu sentido dialético negativo. O eterno retorno de Buchenwald enquanto memória primitiva e primordial não significa que a repetição do mesmo não inclua sua variação. O que se esboça na história desse romance é um tempo vivido em espiral: por um lado, o personagem-narrador dá um longo rodeio para assumir o passado de Buchenwald, quinze anos de postergação, o equivalente à escrita de El largo viaje, e quarenta e nove anos para a publicação de L'Écriture ou la vie; por outro lado, ele gira em torno do tempo do campo de concentração, retorna várias vezes a esse passado para poder sair do mesmo e, ao mesmo tempo, distancia-se várias vezes dessas memórias para poder assumi-las.

O sentido da vivência da morte como essência da experiência manifesta-se na precariedade de ser um sobrevivente testemunha escritor de Buchenwald, pois consiste não somente em ter sobrevivido à morte massiva e onipresente do campo, mas em sobreviver diariamente à presença deste período. A "vivência da morte" dá-se na história da relação do personagem-narrador com sua memória do campo através da escrita literária. É nesta nova história que se desenvolve a sua identidade de sobrevivente testemunha escritor, surgida desse passado atroz. Assim, há duas formas de sobrevivência cujas associações mantidas entre si revelam o sentido dialético da matéria. A transformação que o narrador nos quer narrar é a de um sobrevivente do Holocausto que se transforma em um eterno 
sobrevivente à custa, durante uma fase, da negação de sua identidade através do silêncio e da renúncia à escrita das memórias e à custa, durante uma nova fase em que ele assume essa identidade, do perigo permanente de sucumbir à força destruidora dessas lembranças.

A narrativa busca recuperar como o tempo do campo de concentração operou na vida e na identidade do personagem-narrador uma fissura que se expõe na fissura do tempo de antes e depois do campo, do espaço de fora e interior ao campo. A precariedade desta relação configura um sobrevivente cindido, sobretudo, pelo dilema entre a lembrança e o esquecimento, a fala/escrita e o silêncio, o conhecimento e a ignorância, a consciência e a inocência, o sonho e a realidade, a liberdade e a necessidade, a fraternidade e o Mal, a sorte/casualidade e a causalidade/moral, a aparência e a essência, o idêntico e o não-idêntico. Estes temas dialéticos assumem uma função estrutural no enredo do romance. A segunda transformação, narrada no primeiro plano, refere-se à superação, necessariamente provisória e precária, dessa cisão alienante do eu através da elaboração da vivência da negatividade objetivada na estrutura dialógica-dialética e fragmentária do romance.

No plano do enredo, o retorno a Buchenwald constitui uma ação narrativa que muda sua estrutura e sentido. Com ele, o próprio sentido da sobrevivência e, portanto, da essência da experiência, o Mal absoluto, é transformado. O personagem-narrador visita Weimar devido a uma nova interpretação de um sonho que tinha recorrentemente com Buchenwald. Após ter rechaçado o convite que the fora feito para participar de um evento televisivo sobre Weimar, o sonho que sempre tinha aparece diferente que de costume. Isso o faz mudar de idéia. Ao visitar o campo, em 1992, o personagem-narrador descobre que fora inscrito à sua entrada, em janeiro de 1943, não como estudante de filosofia, como havia orgulhosa e inocentemente declarado, e sim como rebocador de parede. 0 personagem-narrador supõe que esse ato solidário de um companheiro do campo havia provavelmente aumentado sua possibilidade de sobreviver em Buchenwald. O conhecimento dessa informação transforma sua linha interpretativa a respeito da essência da experiência do horror, corroborando a idéia de que o Mal absoluto 
no Holocausto só ganha sentido na relação com a fraternidade, sob o domínio da liberdade da alma humana. Durante a narrativa, o narrador omite o ato solidário do companheiro veterano de Buchenwald. $\mathrm{Na}$ ação narrativa do desfecho do romance, a descoberta aparece como uma anagnoris, recolocando o ato fraterno como elemento que se opõe à essência massiva do Mal Absoluto na experiência do campo de concentração.

O ato solidário do prisioneiro veterano comunista alemão é também um ato de liberdade tradutória que altera a interpretação da experiência. Ou seja, um ato dialógico e hermenêutico que desempenha uma função na estrutura do romance. O personagem-narrador conhece esta ação passada, não coberta pelo tempo ficcional do romance, a partir de sua visita a Weimar. Após o conhecimento desse fato, a sobrevivência deixa de depender para ele somente da sorte. O campo deixa de ser o reino absoluto da necessidade, em que sobreviver é fruto da sorte e não da ação livremente fraterna dos homens. A sobrevivência não é determinada somente pela casualidade/sorte e pela necessidade no meio hostil do campo. A relação dialética entre casualidade e causalidade condicionada à dialética entre liberdade e necessidade participa agora como elemento determinante da sobrevivência, da dialética entre fraternidade e Mal absoluto.

O sentido que subjaz a essa ação narrativa e, portanto, a esse enredo não é estritamente o de que não há volta definitiva do campo ao mundo exterior, mas sim o de que a volta é sempre provisória e precária e de que depende, contraditoriamente, de uma retomada reflexiva e interpretativa da experiência. Essa retomada supõe uma ação permanente no mundo objetivo e exige uma reconstrução constante de seu sentido dada a precariedade do indivíduo que dela se origina e do mundo que possibilitou sua ocorrência. Em La escritura o la vida, a reintegração do sobrevivente no mundo nunca é definitiva e depende de um trabalho de reconciliação permanente com sua história e identidade de sobrevivente, que se dá através da reescrita de si mesmo, uma forma de práxis histórica.

Seria lícito pensar que o romance sugere que somente a origem da história, o regresso à chegada a Buchenwald, explica a história da origem, a identidade que 
nasce da experiência, a transformação do homem sofrida no campo de concentração. Contudo, esse romance representa que a origem da história não está na história da origem. Ou seja, não é a reconstituição da chegada ao campo, da sua rotina e dos horrores ali passados até à libertação, que explica o que ali ocorreu e a identidade do sobrevivente que dele se originou. Como afirma o narrador, não é o mero testemunho que se aproxima do que ele concebe ser a essência da experiência. É na interpretação que a história da origem faz da origem da história que radica a aproximação à essência da experiência. Essa interpretação dá-se na relação do narrador com o mundo presente e na reelaboração de sua relação traumática com a origem da história. É na reconstituição de várias origens, é no presente da elaboração da história da origem - de uma origem perdida porque advinda de uma realidade inesgotável e inatingível, de um presente prenhe da desintegração da identidade - que se apresenta essencialmente o horror. Este é o sentido e a função do perspectivismo. A volta que a narrativa executa ao retornar à chegada a Buchenwald difere da idéia de círculo, pois o retorno supõe, conforme a estrutura do romance, um avanço dialético, uma transformação do mesmo em outro, uma abertura para uma nova atribuição de significado.

A idéia do romance é a de que a forma de regresso possível à liberdade presente do mundo exterior ao campo depende da submissão das lembranças obsessivas à reflexão crítica e à reelaboração literária que as atualiza e transforma a partir de um enfrentamento contraditório. As mesmas lembranças obsessivas podem submeter a reflexão crítica e a reelaboração literária ao regresso definitivo à realidade da morte no campo, ou seja, à impossibilidade definitiva de regresso. Para esse narrador, o imperativo categórico de que é necessário rememorar Auschwitz para que ele não se repita implica a contradição de que a rememoração de Auschwitz possa acarretar sua repetição no nível pessoal e que a não rememoração não o livra de sua repetição no plano subjetivo e menos ainda no histórico e coletivo. Trata-se de um romance cuja impossibilidade de construção definitiva de sentido da experiência narrada determina a condição precária do 
narrador que tem de enfrentar essa negatividade através de um processo de superação permanente e provisória de sua condição.

Analisamos a estrutura dialética deste romance dividindo seu enredo em três momentos que exprimem seu movimento dialético: a tese: a fusão como aporia do regresso à vida; a antítese: a camuflagem como aporia do regresso da vida; a síntese: a diferenciação como aporia do regresso da morte e à morte.

\section{Tese: a fusão como aporia do regresso à vida}

O primeiro movimento do romance, a tese, caracteriza-se por um sentido comum organizador, a fusão. Tanto o personagem-narrador quanto o mundo circundante, concentracionário ou exterior, muito próximos do desastre histórico da Segunda Guerra Mundial e dos campos de concentração, demonstram estar como que colados e impregnados deste desastre. Cada um dos cinco capítulos da primeira parte do romance representa formas de reação do sobrevivente e do mundo em face da recente catástrofe histórica dos campos de concentração nazistas, que manifestam pouco distanciamento e a decorrente dificuldade de reflexão crítica nesta fase da história. Os sentidos corporais, bastante presentes na composição dos capítulos, representam a dialética entre aparência e essência referente à "verdade" da experiência vivida e da nova realidade de liberdade. Assim, os diálogos das cenas centrais de cada capítulo e os fragmentos incidem na busca de reproduzir a dificuldade de o sobrevivente narrar, descrever, refletir e expressar a experiência da catástrofe e a incapacidade de o mundo exterior ouvila e compreendê-la.

\subsection{O reflexo do Mal: a cegueira}

A ação do primeiro capítulo do livro, "La mirada", apresenta a conseqüência do desastre em sua fase paroxística. O personagem-narrador, no dia seguinte à libertação de Buchenwald, 12 de abril de 1945, após passar a noite em Weimar com seus companheiros, depara-se com três oficias das forças aliadas, nas 
imediações do campo, e surpreende em seus olhares um indecifrável horror que Ihe devolve um terrível auto-estranhamento. A imagem de si refletida no outro envolve um processo de auto-alienação, de auto-exílio, uma identidade dissociada de sua auto-imagem. Os oficiais, oriundos de outras paragens, espelham a impossibilidade de se olhar de frente o horror sem dissociar-se de si e do mundo. Nesta situação, o narrador, alternando o seu ponto de vista com o do personagem-narrador, envereda por uma busca atormentada daquilo que pudesse ter provocado os olhares de pavor nos oficiais britânicos e levanta sucessivas hipóteses com respostas sempre inconclusas.

O episódio representa a ação reflexiva de estranhamento entre o olhar do sobrevivente, proveniente das zonas infernais do campo de concentração, e o olhar do mundo, os olhares dos oficiais das forças aliadas. $O$ estranhamento entre ambos alude ao horror em forma de impotência de visão: tanto o sobrevivente tem dificuldade para interpretar este olhar refletido no mundo exterior como este outro de fora do campo exibe sua ignorância do Mal perpetrado nos campos de concentração. A tensão entre a narração e a descrição problematiza a insuficiência do discurso descritivo para caracterizar a catástrofe.

Nos dois primeiros capítulos do livro, os sentidos da visão e da audição, respectivamente, servem de leitmotiv para as ações representadas; associam o mundo exterior à subjetividade do personagem-narrador; atuam como metonímia e metáfora da experiência do campo de concentração; funcionam como paradigma para sondar sua essência e conduzem o tênue fio da narrativa. É principalmente na visão e na audição em que estão inscritas as marcas indeléveis da catástrofe. Os sentidos olfativo, gustativo e tátil concorrem também para a representação desta realidade, no entanto, vão à esteira do olhar e da audição.

Assim, no primeiro episódio do romance, o narrador, quarenta e sete anos depois, lança mão de um olhar que percorre os meandros da memória de Buchenwald a fim de localizar neles as ocorrências, os objetos, as máquinas, as instalações, as personagens, os signos que, relacionados entre si, fazem parte do olhar do personagem-narrador que se reflete no outro, mas que não se deixa expressar verbalmente, nem se deixa captar inteiramente pelos sentidos ou pela 
razão. É através deste olhar aos retalhos, destas incursões nas lembranças do campo, que os signos deste espaço, imantados no corpo do sobrevivente, são apresentados. Este olhar da memória, porém, não chega a ser contemplativo porque a urgência do agora, realizada pela narração em presente verbal da cena central, não nos permite descansar sobre o mundo que ele enfoca. Ao contrário, retira-nos desta posição relaxada, a cada quando, e chama-nos para a insegurança e a hesitação típica do presente. ${ }^{31}$

Com efeito, como padrão narrativo do texto, em cada capítulo o diálogo integra uma cena central, narrada com freqüência em presente verbal, que se desenvolve de forma entrecortada, de maneira que em seus interstícios, cuja extensão varia, enxertam-se fragmentos narrativos que evocam acontecimentos correspondentes a tempos diversos da matéria, digressões, imagens figuradas de caráter reflexivo, fragmentos intertextuais de caráter lírico e descrições. Tais desvios alargam e verticalizam as informações, abrindo, recuando e antecipando o andamento dos temas em função da evolução dialética da história. O padrão de uma narrativa em presente do indicativo cede muitas vezes à perspectiva distanciada de um narrador situado no futuro do enunciado. Há, em certa medida, um movimento na obra pelo qual o narrador nos quer fazer crer, e ao mesmo tempo nos frustra em relação a essa crença, que o que está sendo experimentado simultaneamente está sendo narrado. A estrutura do romance, contudo, deixa patente uma construção dialógica-dialética por fragmentos, modalizados por discursos diferentes e em relação tensional, que não permite a manutenção deste elemento organizador ao longo de todo o livro. ${ }^{32}$

\footnotetext{
${ }^{31}$ Alfredo Bosi afirma a respeito do olhar contemplativo da reminiscência: "E qual é a atividade própria da contemplação? Lembrar. A doutrina da anamnese funda-se na possibilidade de uma visão mental que alcança os reinos do pretérito, vencendo, neste seu ato, os limites do presente, que é finito e mortal como todo tempo corpóreo. (...) De um lado, memória, luminosidade do espírito e sobrevivência chamam-se e completam-se. Do outro: esquecimento, opacidade, morte. Duas dimensões da existência, dois olhares." Assim, a tensão está dada no texto: a par da hesitação entre narrar e descrever - sem contar o refletir e o recitar -, o texto também oscila entre as duas dimensões da existência, lembrar e esquecer, viver e morrer. In BOSI, Alfredo. "Fenomenologia do olhar" in NOVAES, Adauto (Org.) O Olhar. São Paulo: Companhia das Letras, 1988, p. $70-71$.

${ }^{32}$ Vemos como na obra planos temporais distintos entrecruzam-se através de um complexo artifício narrativo. Tais recursos técnicos, que remontam a Sterne, explicitam um domínio das categorias temporais do romance que acarreta, como efeito imediato, a quebra do contrato de ilusão entre leitor e ficção. Ora, este pacto de ilusão que silencia durante a leitura o arranjo da história narrada supõe uma prosa de ficção baseada na
} 
A primeira frase do capítulo lança-nos imediatamente à situação reflexiva da "mirada" dos oficiais do exército aliado: "Están delante de mí, abriendo los ojos enormemente, y yo me veo de golpe en esa mirada de espanto: en su pavor". ${ }^{33} \mathrm{O}$ presente verbal, o "encurtamento da distância estética"34, a imprecisão do sujeito gramatical da primeira oração, a expressão adverbial "de golpe" somada à adjetiva "de espanto" e ao substantivo "pavor" caracterizam uma percepção de um observador colado à circunstância sem poder enxergar muito bem o que narra. Sua capacidade de racionalização e de ordenamento das coisas vistas está reduzida. Além disso, a cena apresenta uma ambientação cunhada pelo impacto. Trata-se do choque do olhar de estranhamento em face do mundo exterior e de uma libertação inesperada.

O narrador explica então que em Buchenwald ele estava impossibilitado de ver seu próprio rosto. Imediatamente fora, o olhar do outro lhe servirá de pista para enxergar-se. Uma pista, contudo, incerta. É justamente não confiando neste jogo especular de olhares e tendo-o como meio de conhecer a si e o mundo que Ihe é dado a testemunhar que o narrador empreende uma rememoração narrativa e descritiva na qual a dúvida não chega a dissipar-se. Assim, o sujeito deste olhar tenta reconhecer no outro o pavor que emana de si mesmo. Trata-se, porém, de um reconhecimento duvidoso, obliterado por um sentimento de horror, atingido na imediatez de um encontro acidental. ${ }^{35}$

invenção e na verossimilhança dos elementos de sua composição. No caso da modalidade do testemunho, como os dados de invenção são muito reduzidos, o fato de expor a "alquimia" de seu arranjo cumpre a mesma função, porém por caminho inverso. O leitor, imerso na veracidade dos fatos narrados e desobrigado de certa maneira do pacto de ilusão, ao perceber a mão condutora do narrador, entra em contato com o caráter ficcional de uma história tão colada à História.

${ }^{33}$ SEMPRÚN, Jorge. La escritura o la vida Trad. Thomas Kauf. Barcelona: Tusquets Editores, 1995, p. 15. A partir desta primeira citação, indicaremos as demais empregando somente o número de página correspondente, já que as extraímos da mesma edição.

${ }^{34}$ Tomamos o termo emprestado de Theodor W. Adorno. In ADORNO, Theodor W.. "Posição do narrador no romance contemporâneo", Notas de literatura I. SP: Editora 34, 2003, p. 61-62.

${ }^{35}$ Shoshana Felman aponta como uma das características da estética do testemunho a situação de acidente que envolve a fala da testemunha. Trata-se de "um testemunho precoce", que se dá de forma incontrolável e imprevista, já que o acidente, metáfora da catástrofe, é "não só a inevitabilidade da determinação da testemunha, na medida em que o acidente a persegue, mas sua prontidão em perseguir o acidente, ativamente seguir seu caminho e sua direção através da obscuridade, da escuridão e das fragmentações, sem, realmente, apreender o alcance e o significado total das implicações, sem prever totalmente para onde conduz a jornada e qual a natureza exata de seu destino." In FELMAN, Shoshana. "Educação e crise, ou as vicissitudes do ensino" in Pulsional. Revista de Psicanálise. Ano XI e XII, n. 116-117, dezembro 1998/janeiro 1999, p. 26. 
À guisa de decifrar este olhar, o narrador reconstitui:

"Desde hacía dos años, yo vivía sin rostro. No hay espejos en Buchenwald. Veía mi cuerpo, su delgadez creciente, una vez por semana, en las duchas. Ningún rostro, sobre ese cuerpo irrisorio."(p. 15)

O sobrevivente que acaba de sair do campo de concentração é um homem sem fisionomia, desprovido do que confere identidade a uma pessoa. A ausência de rosto alude tanto à aniquilação física sofrida como à impossibilidade de ver $\mathrm{e}$ ver-se no campo. A frase "no hay espejos en Buchenwald" colide em seguida com a afirmação de que "se podría haber conseguido un espejo, sin duda". Não se trata, pois, de uma impossibilidade material de se ver e sim de outra índole. Ainda quando o narrador tivesse se fitado ao espelho, a imagem refletida não the devolveria um rosto. Um corpo "borroso" não sustenta um semblante, pois nele ocorre a perda da carne e da vida da individualidade. O que pode ver um homem sem rosto? A sombra de si mesmo, a massa homogênea de rostos ausentes, olhares sem força e sem intencionalidade, incapazes de distinguir nesta mesma massa sua própria identidade.

Intrigado pela ausência de uma resposta definitiva, o narrador descreve-se, negando que sua cabeça raspada, sua indumentária e magreza pudessem ser a causa deste olhar de espanto e logo supõe: "Es el horror de mi mirada lo que revela la suya, horrorizada. $\mathrm{Si}$, en definitiva, mis ojos son un espejo, debo de tener una mirada de loco, de desolación." (p. 16) O personagem-narrador infere sem certeza a loucura e a desolação deste olhar, pois o encontro de duas superfícies especulares, vazias de imagem, o que pode revelar? A loucura, a alienação, aquilo que está fora de si e sempre no outro, porque em si não é discernível. A desolação, a ruína do ser, o próprio sentido que o capacita a conhecer a destruição de si. A descrição dos olhos dos oficiais das forças britânicas insiste neste vazio do horror do campo, em sua "ceguera pavorosa": "ojos desorbitados" que ao fugirem da cavidade óssea em que se alojam revelam que a coisa vista extrapola o domínio do corpo e da compreensão.

$\mathrm{O}$ andamento do capítulo mostra que o desejo de compreender não se dá por satisfeito. $O$ personagem-narrador rompe a paralisia muda da situação do 
olhar, indagando aos oficiais se "¿es el silencio del bosque lo que tanto os extraña?" (p. 17) A provocação desvia o enfoque narrativo da visão para a audição, introduz o silêncio como outra forma de estranhamento. O pavor do olhar está circundado pela ausência de linguagem. O mundo interior da ausência de visão do sobrevivente do campo relaciona-se com o mundo exterior do inaudito.

Após o levantamento desta nova hipótese, o narrador explica: "No, no es el silencio. Nada les había llamado la atención, no habían oído el silencio. Quien les llena de espanto soy yo, eso es todo, manifiestamente." (p. 17) Porém, diante dos soldados o personagem-narrador alude a outro indício do horror: “_Se acabaron los pájaros - digo, siguiendo mi idea -. El humo del crematorio los ha ahuyentado, eso dicen. Nunca hay pájaros en este bosque..." (p. 17)

A explicação do silêncio do bosque vincula o sentido auditivo ao olfativo, integra-os na idéia de que nem, ou sobretudo, os pássaros puderam suportar o "extraño olor" exalado pelo forno do crematório. A debandada dos pássaros, em oposição ao confinamento dos prisioneiros, representa o grau de sofrimento impingido aos últimos; coteja homem e animal na agonia da percepção. A imagem revela a "vida nua" 36 , ponto comum entre homem e animal, e alude ao grau extremo de rebaixamento do homem submetido às práticas de violência nos campos nazistas.

A propósito do "extraño olor" dos fornos crematórios, o narrador expõe brevemente a vida de León Blum, a quem pertence a expressão. León Blum ${ }^{37}$,

\footnotetext{
${ }^{36}$ A imagem enunciativa remete-nos à acepção de zoé, vida nua, conceito proposto por Giorgio Agamben com a finalidade esclarecer o "oculto ponto de intersecção entre o modelo jurídico-institucional e o modelo biopolítico do poder". A complexidade do conceito concerne à articulação entre a esfera do poder soberano e a vida não qualificada politicamente. Lançando mão do pensamento de Foucault e de Benjamin, Agamben mostra como o poder do Estado moderno fundamenta-se na exclusão inclusiva da vida nua, porque é em forma de exceção que ele se torna regra. Contudo, a primeira acepção de vida nua é legada pelo pensamento de Aristóteles. Segundo Agamben, zoé para o filósofo grego correspondia a um dos termos que designavam a palavra vida. Por zoé entende-se a forma de vida natural, comum a todos os seres vivos (animais, homens ou deuses), a vida mínima de um ser vivente cuja capacidade de discernimento alcança somente a dor e o prazer; enquanto bíos significa a vida qualificada do cidadão unido a uma comunidade politicamente organizada para o viver bem, fundada no logos, na linguagem, pressupostos da faculdade humana de discernir o bem do mal, o justo do injusto. In AGAMBEN, Giorgio. O poder soberano e a vida nua I. Trad.: Henrique Burigo. Belo Horizonte: UFMG, 2004, p. 14.

${ }^{37}$ León Blum (1872-1950), intelectual francês, socialista. Deputado em 1919, tornou-se líder do Partido Socialista em 1924. Foi um dos formadores, em 1935, da Frente Popular formada pelo Partido Comunista, Partido Socialista e Partido Radical. Em 1936 foi eleito Primeiro Ministro da França. Na sua gestão introduziu a jornada de trabalho de 40 horas semanais, nacionalizou o Banco da França e a indústria de armamentos e
} 
enclausurado "en un chalet del barrio de los acuartelamientos SS de Buchenwald" (p. 18), alheio à existência do campo de Buchenwald, encontra-se numa situação de ignorância apenas quebrada pelo "extraño olor (...) de los hornos crematorios". Este cheiro, caracterizado pelo narrador como "dulzón, insinuante, con tufos acres", nauseabundo, insólito e, por fim, obsessivo, descortina para Blum o que sua vista não era capaz de alcançar; abala sua dificuldade de ver, trazendo-lhe um indício das práticas de aniquilamento de Buchenwald.

Por intermédio desta propriedade insinuante e obsessiva do cheiro, 0 narrador liga a experiência de León Blum à dele: "Extraño olor, en verdad obsesivo". Mas "el extrãno olor" de León Blum contrapõe-se à familiaridade com que o personagem-narrador conviveria com a memória do mesmo. O horror manifesta-se através da inversão entre as noções de familiar e estranho. 0 narrador apropria-se das palavras de León Blum e desloca seu sentido: o estranho, faceta do horror, reside em sua transformação em familiar. O espaço do campo de concentração e seus odores surgem como casa natal, lugar de origem, pátria-morte. $^{38}$

Ao relembrar os dias que antecederam o dia da "mirada", a libertação de Buchenwald, o narrador descreve a rebelião organizada pelo aparelho clandestino

adotou outras reformas sociais. Durante a Guerra Civil Espanhola tentou enviar aviões e armamentos para os Republicanos, mas, pressionado pela direita, recuou e passou apenas a defender junto aos outros países europeus a não intervenção no conflito. Perdeu o apoio do Partido Comunista e terminou renunciando ao cargo. Em 13 de março de 1938 retornou ao cargo de Primeiro Ministro e então abriu as fronteiras com a Espanha para permitir o envio de armamentos. A direita reagiu violentamente e em 10 de abril seu governo caiu. Com a invasão da França pelos alemães fugiu para o sul do país, mas foi preso pelo governo de Petain. Foi julgado como traidor em fevereiro de 1942 e entregue aos alemães que o mantiveram prisioneiro até 1945.

${ }^{38}$ A idéia de pátria-morte constitui uma das imagens dialéticas da experiência do campo de concentração para o narrador, já que ele se considera um apátrida. O sentimento de desabrigo do escritor, apontado por Valeria De Marco em "A literatura de testemunho e a violência de Estado" como uma tônica da literatura do testemunho e da literatura do século xx, é representado nesta obra pelo significado do campo como pátriamorte. A morte, assim, significa um lugar de origem, não o fim. O sujeito que passou pela experiência do campo encontra a morte como território do qual é proveniente. Valeria De Marco discute a questão do desabrigo territorial, fenômeno dos movimentos massivos de refugiados e exilados de nossa época, mostrando como ela se manifesta na relação do escritor contemporâneo e do testemunho com sua língua materna. Conforme a autora, o desabrigo implica antes uma expulsão lingüística do que propriamente territorial. O mal-estar e a fissura irremediáveis operados entre língua e vivência entranham diferentes aspectos presentes na literatura do testemunho. A autora aponta "a alusão ao indizível", a ausência de interlocução, o deslocamento das noções de natural e estranho, a busca incessante por uma expressão adequada, "a exploração da dicção própria da oralidade e da frase coloquial", o impasse diante da insuficiência da tradução, o conflito com a língua dos opressores quando correspondente à língua materna, como exemplos desses aspectos. In DE MARCO, Valeria. "A literatura de testemunho e a violência de Estado" in Lua nova, São Paulo, n. 62, 2004, p. 45-68. 
do campo do qual fazia parte e o estado de desespero dos prisioneiros que eram evacuados e mortos massivamente pelos S.S. em face da chegada dos aliados. As condições dos prisioneiros mais fracos evacuados e dos combatentes que permaneceram no campo apontam para uma libertação e sobrevivência improváveis, que também são plasmadas sob o signo da "ceguera pavorosa": "Ninguno de nosotros, jamás, se habría atrevido a soñar algo así. Ninguno había estado lo suficientemente vivo como para soñar incluso, para arriesgarse a imaginar un porvenir." (p. 22) A impossibilidade de sonhar a sobrevivência significa a impossibilidade de vislumbrar um futuro. Não poder imaginar e não poder vislumbrar abrigam a perda da capacidade da visão. Não se ver no futuro implica que o lugar de onde se olha não dá acesso à sua perspectiva. O campo suprime no indivíduo a motricidade do olhar, paralisado e absorvido na hipertrofia de sua onipresença. Se o futuro não tangenciava a visão, era então improvisus (sem ver de antemão). Daí a libertação e a sobrevivência serem afins ao sentido da perda da faculdade de olhar. ${ }^{39}$

Como que por ondas sinuosas em torno de um eixo, idas e vindas, a narrativa inicia o quinto fragmento, recuperando a cena do olhar a partir do momento anterior, o da vontade de rir do personagem-narrador. $O$ riso do personagem-narrador, o silêncio dos soldados, a boca seca de um, o tique nervoso do outro, o desvio de olhar do francês, gestos e trejeitos simultâneos que revelam um desconcerto entre suas reações. O descompasso entre sobrevivente e soldados assinala um desencontro, surgido do encontro. Segundo o narrador, sua descontração devia parecer um despropósito aos olhos dos soldados, pois sua aparência descartava a possibilidade de qualquer alegria residir em seu espírito. Esse embaraço cria uma desorientação, um hiato de sentido. $O$ sobrevivente sente que seu riso está "fuera de lugar". A impropriedade de seu riso denota e conota o estado deplorável de quem veio de um lugar fora de qualquer lugar. Ademais, indica o desvão, a lacuna de compreensão gerada no espírito de quem se depara com este "incômodo homem".

\footnotetext{
${ }^{39}$ Lembremos que improviso também significa súbito, inopinado, maneira como se manifesta o ato de testemunhar deste narrador que escolhe narrar as cenas centrais de cada capítulo em um agora que urge.
} 
O sobrevivente insistirá na justificativa dos pássaros que fugiram da fumaça do crematório para explicar agora a insensatez de seu riso: “_El crematorio se cerró ayer - les digo -. Nunca más habrá humo en el paisaje. ¡Tal vez vuelvan los pájaros!" (p. 22) O resultado, no entanto, demonstra que o desentendimento não é superado: "Tuercen el gesto, vagamente asqueados." (p.22)

O narrador então supõe que eles não tenham captado o sentido das palavras. A descrição dos aspectos variáveis do "humo" ("denso", "negro", "gris"), captáveis a olho nu, mostra como apesar dessa aparência visível e descritível a fumaça guarda um significado inacessível àquele que não tenha vivenciado o campo de concentração. Assim, a narrativa trata de um significado da palavra "humo", que escapa à sua literalidade. A linguagem não pode superar a separação intransponível entre o sobrevivente e o outro, a vivência e o conhecimento, apenas expressá-la indicando o indescritível através da descrição.

Mas para o narrador a impossibilidade de acessar esse conhecimento não se restringe somente ao outro, pois também o sobrevivente está impossibilitado de apreender sua significação total:

"Humo para una mortaja tan extensa como el cielo, último rastro del paso, cuerpos y almas, de los compañeros. Se necesitarían horas, temporadas enteras, la eternidad del relato para poder dar cuenta de una forma aproximada." (p. 24-25)

A imagem do céu, símbolo da imensidão, expressa de modo literal e figurado a extensão sem limites da mortalha de fumaça dos corpos e almas dos companheiros. Em conformidade com a infinitude da morte no campo, a transmissão verbal desta experiência requer a "eternidad del relato", um tempo infinito "para poder dar cuenta de una forma aproximada". Os signos espaciais do mal sem limites em Buchenwald são correlatos à eternidade de sua narração e à sensação de duração ilimitada da experiência. A impossibilidade de o outro ver as implicações do horror encontra um paralelo na impossibilidade de ver da testemunha. A invisibilidade do significado da experiência para o outro se explica por não pertencer ao âmbito de sua vivência, ao passo que para a testemunha ela se enraíza no caráter excessivo da experiência, que extrapola sua faculdade visual, percepção que articula a própria linguagem. 
A dúvida sobre se é possível contar e transmitir a experiência recai sobre o destinatário do testemunho que, segundo o narrador, deveria empreender um esforço de imaginação e possuir atributos como paciência e compaixão para que o circuito comunicativo se cumprisse. O olhar dos primeiros receptores corrobora a incerteza sobre a possibilidade de contar na interface de escutar: terror, hostilidade e desconfiança combinados ao silêncio e à resistência reforçam esse impasse. Essa dúvida desencadeia uma nova incerteza, a de ter sobrevivido de fato. O narrador questiona, através da acumulação de palavras pertencentes ao léxico da visão ("evidente", "adivinar", "mirada", "espejo") o estatuto de vivente do sobrevivente mediante a auto-imagem refletida no olhar do outro:

"Me he visto en su mirada horrorizada por primera vez desde hace dos años. Me han estropeado esta primera mañana (...) Estaba convencido de haberlo superado con vida. Devuelto a la vida, cuando menos. No es tan evidente. Tratando de adivinar mi mirada en el espejo de la suya, no parece que me encuentre más allá de tanta muerte." (p. 26-27)

O narrador então substitui o termo sobrevivente por "aparecido". O recurso dos termos "resuscitado", "fantasma", subverte a noção estrita da palavra sobrevivência, conforma a aporia do regresso ao mundo e participa da concepção da essência da experiência, a vivência da morte. ${ }^{40} \mathrm{O}$ sobrevivente fantasma, espectro do vivente, sombra de si mesmo, atende à contradição resultante da experiência da catástrofe: continuar a existir para quem vivenciou a morte significa

\footnotetext{
${ }^{40}$ Conforme Felipe Nieto, a memória da experiência da deportação na obra de Semprún representa um trauma que torna sua sobrevivência precária, cindida em um dilema: contar e escrever, o que o remete à dor insuportável de recordar a experiência, ou calar e esquecer, recurso para conservar-se com vida. Para Felipe Nieto, este dilema, a culpa de ter sobrevivido quando os companheiros não tiveram o mesmo destino e o imperativo ético de denunciar as atrocidades em nome dos companheiros desaparecidos constituem os temas fundamentais de La escritura o la vida. O autor classifica o livro de Semprún e os demais pertencentes ao ciclo de Buchenwald (El largo viaje, Aquel domingo, Viviré con su nombre, morirá con el mío), uma escrita memorialística. Segundo Nieto, o estatuto de ressuscitado, estratégia do sobrevivente para mover-se em um mundo estranho, um mundo entre duas mortes, ganha um caráter literário neste romance. Felipe Nieto afirma que a memória do "resucitado" Semprún, uma das poucas testemunhas que restam, deve ser imortal para tornar-se verossímil. A memória inesgotável da testemunha Semprún liga-se, portanto, a um recurso de sua imaginação literária que transmite a visão de quem sente ter vivenciado a morte e tem como tarefa manter viva a memória do Mal como forma de luta pela liberdade e dignidade humana. In NIETO, Felipe. "La 'resurrección' de Jorge Semprún: El regreso de Buchenwald" in Revista de Occidente, n. 266-67, Julio-Agosto 2003, p. 205-15.
} 
trazer consigo nesta continuidade a própria descontinuidade da vida, o seu fim. ${ }^{41}$ A aporia do regresso à vida liga-se no capítulo à impossibilidade de ver e ser visto como um sobrevivente.

A luz "da mirada horrorizada" dos oficiais das forças aliadas, que pousa sobre o personagem-narrador, faz o narrador lembrar-se dos olhares dos companheiros do campo, de suas "miradas fraternas". A dialética entre o Mal radical e a fraternidade, fundamental na estrutura do texto, aparece no primeiro capítulo vinculada ao episódio da morte de Maurice Halbwachs, seu professor da Sorbonne, cujo olhar é descrito à hora de morrer como fraterno e digno. O texto alcança o paroxismo do motivo do olhar com base em uma tensa interação entre narrar e descrever. A condição dos prisioneiros é sondada pelo narrador que persegue seus signos nos olhares das vítimas, das vítimas-algozes e dos algozes. Mas a descrição dos olhares fraternos que rodeavam o personagem-narrador, fazia quase dois anos, sofre uma inflexão reflexiva, pois o narrador questiona a própria existência de olhares na maioria dos deportados em Buchenwald:

\begin{abstract}
"Iba a hacer dos años que vivía rodeado de miradas fraternas. Si es que había miradas: la mayoría de los deportados carecían de ella. La tenían apagada, obnubilada, cegada por la luz cruda de la muerte. La mayoría de ellos sólo vivía debido a la inercia: luz debilitada de una estrella muerta, su mirada." (p. 29)
\end{abstract}

A imagem evocada apresenta o olhar como região de intercessão de dois focos de luz: um, somente interno, o do prisioneiro, outro, externo, o do meio. A luz crua da morte é oriunda da invasão e da ameaça constante de aniquilamento do espaço circundante sobre o espaço corpóreo e psíquico do prisioneiro, ofuscando sua visão e luz interior. O ser dotado de luz própria aparece na metáfora da "estrella muerta". Seu olhar transmite uma luz debilitada porque ele, em processo moribundo, deixou de irradiá-la; daí a inércia do movimento

\footnotetext{
${ }^{41}$ Geoffrey H. Hartman discorre sobre o senso de irrealidade que subsiste na vida dos sobreviventes, citando inclusive trechos do testemunho de Jorge Semprún: "freqüentemente (os sobreviventes) se sentem como se nunca tivessem deixado o lugar no qual tantos morreram. Eles também parecem ter morrido durante aqueles anos terríveis, sendo agora fantasmas que se autoperseguem." In HARTMAN, Geoffrey H.. "Holocausto, testemunho, arte e trauma" in NESTROVSKI, Arthur e SELIGMANN-SILVA, Márcio (orgs.) Catástrofe e representação. São Paulo: Escuta, 2000, p. 207-235.
} 
luminoso. A morte reside fora e dentro do indivíduo. Sua fonte exterior penetra e merma a luz interior do indivíduo exposto a ela. A luz interior do indivíduo provém da porção vital que existe nele. Sua cessação significa a escuridão interior. Aqui, o olhar desempenha sua dupla função de janela do mundo interior, obliterado, e espelho do mundo exterior, devastado. O resultado é uma cegueira dual, irreversível. A "ceguera pavorosa" do campo de concentração tem duas faces indissociáveis: a escuridão da vida interior e a luminosidade da morte exterior. Ambas encontram no olhar do homem o elo de sua relação dialética destrutiva, transformando-se na escuridão da vida exterior e na luminosidade da morte interior.

O último fragmento do capítulo descreve o olhar dos SS. O narrador enfatiza a dificuldade em captá-lo e o ódio que ele expressava:

"Pero no era fácil captar su mirada. Estaban lejos: macizos, por encima, más allá. Nuestras miradas no podían cruzarse. Pasaban, atareados, arrogantes, destacándose en el cielo pálido de Buchenwald, donde flotaba el humo del crematorio." (p. 36)

A imagem compara os SS com seres agigantados, inabaláveis. Ao posicioná-los nas alturas celestes, junto à fumaça do crematório, o narrador ironiza sua superioridade em relação aos prisioneiros, já que ali, embora separados, encontravam-se no mesmo patamar. É na ação exterminadora dos SS que ambos se nivelavam. Além disso, não poder captar o olhar dos SS devia-se a uma regra tácita destinada à anulação da autonomia dos prisioneiros. A submissão total dos prisioneiros refere-se à impossibilidade da atividade do olhar dos mesmos. O olhar inatingível dos SS que os esmagam, esmaga-os também por sua invisibilidade, por impedir que o outro exerça sua faculdade cognoscente através de seu corpo sensível. ${ }^{42}$ Mas, segundo o narrador, a usurpação do olhar dos prisioneiros, às vezes, "con un poco de audacia y de astucia", podia ser burlada. O obersturmfürer Schwartz torna-se o personagem que singulariza o ódio

\footnotetext{
${ }^{42}$ Bruno Bettelheim analisa como a desintegração da personalidade do prisioneiro estava intimamente ligada ao imperativo de não observar nada além daquilo que fosse permitido pelos S.S.. A autodeterminação e a vida independente do raciocínio atrofiavam-se com o desuso do poder deliberado de observação. In BETTELHEIM, Bruno. O coração informado. Trad. Celina Cardim Cavalcanti. RJ: Paz e Terra, 1985, p. 124-126.
} 
no olhar dos SS. Este ódio confuso e desassossegado provoca-lhe, paradoxalmente, um conforto e o desejo de sobreviver, ao passo que a fraternidade entre os companheiros na experiência da morte o faz desistir da vida e torna a vida vã. O ódio mortífero dos SS remete o prisioneiro à vida, assim como a vivência da fraternidade o remete à morte.

Os últimos parágrafos do capítulo retomam a "mirada horrorizada" dos três oficias de uniforme britânico:

"Pero hoy, este día del mes de abril, después del invierno que ha cubierto Europa, después de la lluvia de acero y de fuego, ¿a qué me remite la mirada horrorizada, descompuesta, de los tres oficiales que visten uniforme británico?

¿A qué horror, a qué locura?” (p. 37)

A impossibilidade de ver aqui consiste em não poder "remitir", enviar, traduzir o horror refletido no olhar do outro. O adjetivo "horrorizada" não é suficiente para tornar o mundo do campo de concentração decifrável aos olhos do sobrevivente. O narrador termina com uma indagação sem resposta a respeito do conteúdo deste horror, desta loucura, porque não pode ser vertido em uma forma lingüística definitiva, carregada de um significado pleno, indubitável. A loucura, como ausência de discernimento da razão e da consciência, participa da visibilidade do objeto de conhecimento e consiste na "ceguera pavorosa" deste horror.

A primazia dos sentidos, a serviço da sondagem da essência da experiência da catástrofe, faz-nos pensar que, apesar de a narração constituir-se no carro-chefe da composição neste capítulo, é a descrição que ocupa um lugar privilegiado na fatura do texto. A abundância de adjetivos justifica a potência descritiva do texto. No entanto, a situação do narrador não sustenta uma pura descrição desinteressada. Deste modo, a narração em primeira pessoa, conjugada com o presente verbal da cena central, tonifica o locus de uma voz que se encontra no limiar entre a voz e a ausência de voz. Resta pouca coisa ao sobrevivente além dessa vivência que, por aproximar-se da negação da vida, pertence a ele de tal maneira que dificilmente poderia ser compartilhada com uma terceira pessoa pretérita e distanciada com a qual narrar. Sua narração descritiva, 
ao invés de desprendida, busca os signos, os objetos, as experiências, as relações inter-humanas em Buchenwald que vieram inscrever-se no seu corpo e no seu eu. A narração compõe-se de fragmentos discursivos e episódicos não autônomos que revelam a íntima relação entre o espaço da catástrofe e o aniquilamento do homem que a viveu.

Há uma tensão entre narrar e descrever neste capítulo, que aponta para a insuficiência de o discurso descritivo dar conta da realidade do campo de concentração. A cena central constitui uma situação descritiva dual e reflexiva. Temos, ao mesmo tempo, uma personagem que olha e é olhada, um verbo de percepção (mirar) e a notação do meio transparente, os olhos do outro. O que está sendo olhado, o olhar de pavor do outro, advém e espelha o olhar daquele que olha. De sorte que o horror do olhar do outro integra a nova identidade de sobrevivente do personagem-narrador. Esta nova identidade, desconhecida e estranha a si mesmo, manifesta quão próximo ele se encontra de sua vivência de Buchenwald. Por isso, a "descrição" deste horror captado no olhar do outro se liga intimamente ao seu novo eu. O outro, como uma janela de si e espelho do mundo que o personagem-narrador carrega, revela um estranhamento, uma incapacidade compreensiva, que reflete a impossibilidade de o sobrevivente reconhecer-se nesta relação de alteridade especular. Ademais, é este valor descritivo inaugural que repousa nos fragmentos intercalados à cena central: o mundo do campo de concentração, por seu caráter excessivo e traumático, tampouco se sujeita à visão cognoscente do personagem-narrador. A impossibilidade de ver implica, portanto, a impossibilidade de atingir a essência deste horror através da descrição. A narração e as outras formas de discurso empregadas no capítulo, em contradição com o valor descritivo do texto, funcionam como uma "saída", uma mediação, para a precariedade do sujeito que olha, para o mundo inesgotável e inapreensível que é objeto de seu olhar, para o meio de transparência, um espelho obtuso e opaco, nada transparente.

O capítulo em sua unidade representa a dialética entre dentro e fora, antes e depois do campo de concentração, que se dá em termos de fissura na existência do sobrevivente. A imagem da "ceguera pavorosa" é a expressão mais viva desta 
cisão. Depois da experiência em Buchenwald, o personagem-narrador não consegue reconhecer claramente que se encontra fora dele, pois o outro de fora Ihe projeta este estranhamento, esta ausência de interlocução, que o atrapalha reconhecer-se pertencente ao novo mundo conquistado enquanto sobrevivente. Este homem, isolado no horror, não coincide mais com o mundo de fora. É como se ele se perguntasse: por que não me reconhecem? Não me vêem? Ou sou eu quem não consigo vê-los? Não sou visível? E como desdobramento desta última aporia: estou cego porque sou o horror ou sou o olhar que o horror cegou? ${ }^{43}$

A proposição descritiva da cena central do capítulo conforma uma aporia expressa na forma e na temática da obra. O acontecimento do encontro (desencontrado) de olhares constitui um núcleo, pois instaura a incerteza de o narrador ser realmente um sobrevivente e pertencer a este mundo exterior integralmente. Os fragmentos interpolados entre os trechos do núcleo configuram catálises de caráter indicial, cuja função é a de explicar, e mostrar como isso não é possível, a transformação catastrófica deste sobrevivente nesta "ceguera pavorosa". O campo de concentração, então, é o espaço do qual a testemunha surge pavorosamente cega ou cegamente pavorosa.

Descrever narrando ou narrar descrevendo esta "ceguera pavorosa" representa uma impossibilidade ao sujeito da descrição, ao mundo a ser descrito, ao meio de transparência que se oferece à visão e ao meio lingüístico como veículo de sua transmissão. Cabe ressaltar que esta aporia de descrever o espaço da catástrofe ou narrá-lo aqui não significa afirmar que o autor realmente não poderia ter "escolhido" descrevê-lo e sim dizer que a elaboração deste capítulo atribui um sentido de impossibilidade de escolha a este modo de representação, o que faz do texto um questionamento, já em sua gênese, de sua própria forma, uma metaliteratura.

\footnotetext{
${ }^{43}$ Valeria De Marco observa que "La acción representada en esa escena de espejamiento es la confrontación silenciosa de miradas y no el encuentro; es el espanto, el extrañamiento, la imposibilidad de reconocimiento y de comunicación. Si quisiéramos traducir ese silencio, podríamos formular una confrontación de preguntas. El narrador percibe que los soldados indagan: ¿qué es? ¿quién es? Y, frente a esa invectiva, él se pregunta: ¿quién soy? El silencioso extrañamiento denuncia la existencia de un otro irreconocible y le impone al personaje la conciencia de ser diferente de lo que pensaba que era. La necesidad de responder a esas preguntas se proyecta en la exigencia de narrar, es decir, de reconciliarse con su historia cuya génesis está en ese episodio, en ese extrañamiento." In DE MARCO, Valeria. "La escritura o la vida: la imposibilidad de ver", texto mimeografado, 2001, p. 4.
} 
Tal material histórico e o seu modo de representação literária podem ser pensados a partir da interpretação de Giorgio Agamben sobre a condição da testemunha da Shoah. Essa relação, interpretada anteriormente por Valeria De Marco ${ }^{44}$, reitera a linha de análise desenvolvida até agora. A situação do muçulmano, testemunha integral, é definida por Agamben como a daquele que viu a Gorgona, a anticara, a própria impossibilidade de ver junto a um apelo inevitável de olhar. O muçulmano representa o não-homem do campo de concentração e sua condição está dada por um ato de visão particular, talvez um não-ato, pois, segundo o autor, "el musulmán no ha visto nada, no ha conocido nada, salvo la imposibilidad de conocer y de ver." ${ }^{45}$ À diferença do muçulmano, a testemunha não vê diretamente a Gorgona, mas vê aquele que a viu. Assim, para o pensador, "La Górgona y el que la ha visto, el musulmán y el que da testimonio en su lugar, son una mirada única, la misma imposibilidad de ver." ${ }^{46} \mathrm{O}$ espelhamento torna-se um recurso literário de "olhar" para representar o horror inscrito em si.

\subsection{O eco do Mal: a voz da agonia e a agonia do silêncio}

O segundo capítulo do romance, "El kaddish", destaca o sentido da audição no concurso da fatura da obra. Em 14 de abril de 1945, no campo de concentração de Buchenwald, à espera de serem repatriados, os ex-prisioneiros membros do comitê internacional do campo fazem parte de uma operação de salvamento. O personagem-narrador e Albert, seu companheiro responsável pela operação de salvamento e ex-combatente das Brigadas Internacionais na Espanha, ouvem uma voz agonizante proveniente do barracão do "Campo Pequeño", enfermaria de Buchenwald. Ambos hesitam a respeito da origem e do que significa essa voz. Ambos duvidam de que se trata de um sobrevivente que deve ser salvo. A ação narrada gira em torno do salvamento de um ex-prisioneiro

\footnotetext{
${ }^{44}$ A análise deste capítulo deve contribuição à relação estabelecida por Valeria De Marco entre a teoria de Agamben e as formas de cegueira representadas pelo narrador deste romance. DE MARCO, Valeria. Ibdem.

${ }^{45}$ AGAMBEN, Giorgio. Lo que queda de Auschwitz. El archivo y el testigo. Homo Sacer III. Trad. Antonio Gimeno Cuspinera. Valencia: Pre-Textos, 2000, p. 55.

${ }^{46}$ AGAMBEN, Giorgio. Ibidem, p. 55.
} 
judeu agonizante que se esforça em proferir a oração fúnebre judaica e representa a dificuldade de se descrever de modo preciso e definitivo essa voz e de se comunicar com ela.

O efeito estético do Mal representado é o do eco: a voz indiscernível do agonizante reverbera outras vozes, catalisa e dispersa ao mesmo tempo rememorações do narrador, reflexões, descrições, intertextos, situações em que ele se deparou com outras mortes desse mesmo tempo de catástrofes históricas. Este diálogo com as vozes de outras mortes não pode, contudo, explicar e transmitir por completo o eco do Mal do campo. O emprego da antítese, da gradação e do paralelismo, conjugados no nível das ações, das imagens, das descrições, das digressões, constitui a técnica para objetivar o sentido do eco da morte neste capítulo. A dialética representada pela fragmentação que dialoga com as vozes intertextuais da morte é a de que a morte dos campos de concentração não dialoga.

Por um lado, a ação dá seguimento ao núcleo representado pelo "encontro" do personagem-narrador com os oficias das forças aliadas nas imediações de Buchenwald. Por outro, este episódio contrapõe-se ao primeiro, pois, ao invés do estranhamento com os de fora do campo, ele indicia uma identificação com os de dentro. ${ }^{47} \mathrm{O}$ motivo da audição opõe-se ao da visão na medida em que ocorre um retorno às regiões do inframundo do campo e a uma identidade nele fundada. ${ }^{48}$ Mas tanto o olhar de fora, "de la vida", confunde o sujeito do olhar da catástrofe no discernimento do ser e do parecer, como a voz de dentro, "de la muerte", recoloca essa dificuldade de discriminação entre aparência e essência. A multiplicidade aparente das vozes da morte manifesta a impossibilidade de se identificar o essencial entre as mesmas. Múltiplas vozes, emitidas de lugares diferentes,

\footnotetext{
${ }^{47}$ Esta sintaxe funcional do texto, que assume também um caráter indicial e integrativo, é observada por Valeria De Marco: "Si en el primer episodio aparece la cuestión de darse cuenta de que es un sobreviviente, de percibir que provoca el extrañamiento de los que vienen de fuera del campo, el episodio siguiente se vincula con este por la búsqueda del confort proveniente de poder reconocerse entre sus iguales: un compañero de alambradas que él ayuda a salvar y un sobreviviente de Auschwitz cuya figura evoca." In DE MARCO, Valeria. Op. cit., p. 7.

${ }^{48}$ Marilena Chauí examina a diferença entre ver e ouvir, segundo a concepção platônica, e conclui: "Ver, lança-nos para fora. Ouvir, volta-nos para dentro." In CHAUÍ, Marilena. "Janela da alma, espelho do mundo" in NOVAES, Adauto (Org.), op. cit., p. 47.
} 
produzem uma polifonia cuja busca de coesão textual realiza-se mediante a fragmentação discursiva.

Desta maneira, a cena central de "El kaddish" começa com uma frase que constitui uma analogia antitética em relação à primeira frase do episódio principal do primeiro capítulo. Após recorrerem o barracão da enfermaria do Campinho, ao saírem, Albert e o personagem-narrador ouvem "Una voz, de repente, detrás de nosotros." (p. 38) ${ }^{49}$ Em vez do olhar, encontramos "una voz"; no lugar do "yo" do personagem-narrador, temos o "nosotros" (o personagem-narrador e Albert) como predicativo do sujeito e o sujeito "ellos" (os oficiais das forças aliadas) é substituído por "una voz". A posição entre o sujeito e o outro se inverte: a voz está "detrás de nosotros". O índice modal de tempo "de repente" ocupa o "de golpe", repetindo a urgência em narrar o choque. Ou seja, toda a situação é invertida. $O$ personagem-narrador está na posição mais passiva de ouvinte, receptor da voz, e de costas para a voz do campo, voltado para "fora".

Em seguida, o discurso sofre uma inflexão, tomando a mesma direção das indagações e incertezas: “¿Una voz? Queja inhumana, más bien. Gemido inarticulado de animal herido. Melopea fúnebre que hiela la sangre en las venas." (p. 38) A forma interrogativa assume um papel enfático, pois toda a caracterização da voz posterior à frase visa antes a questionar o estado de quem a emite e o lugar de onde é proferida. O seu sentido dialoga com a questão de Primo Levi que deu o título ao seu livro: É isto um homem? ${ }^{50}$ À guisa de variação sobre o mesmo

\footnotetext{
${ }^{49}$ Para a facilidade do leitor, reproduzimos a frase inicial do livro: "Están delante de mí, abriendo los ojos enormemente, y yo me veo de golpe en esa mirada de espanto: en su pavor."

${ }^{50}$ Giorgio Agamben persegue em seus estudos sobre o testemunho da Shoah o que ele chama de "lacuna", isto é, uma parte fundamental dos arquivos dos testemunhos que revela escondendo um conteúdo da experiência catastrófica dos muçulmanos, daqueles que "tocaram o fundo", e que não se submete docilmente ao testemunho dos sobreviventes. Segundo o autor, tal lacuna pode ser identificada no relato de Primo Levi sobre Hurbinek, nome dado pelos deportados, em Auschwitz, a um menino paralítico de três anos de idade que não sabia falar. Primo Levi recolhe um som incerto que Hurbinek passa a articular, sem sentido, repetitivo, transcrito como massklo ou matisklo. Para Agamben este evento ilustra sua tese de que nem o sobrevivente pode testemunhar integralmente, ou seja, dar testemunho da "testemunha integral" que tampouco pôde testemunhar, já que lhe faltaram a língua ou a linguagem, o pensamento e a memória, a força ou a vontade de falar. A lacuna corresponde, pois, a esta ausência testemunhal implicada na voz da testemunha sobrevivente, a sobrevivência da ausência. Conforme Agamben, o valor do testemunho reside justamente nesta "zona imprevista" que deve ser escutada e lida nos testemunhos dos sobreviventes, se não quisermos nos dobrar ao seu caráter enigmático e mistificá-lo como impenetrável, sublime, irrepresentável em absoluto. Enquanto possibilidade de palavra, o testemunho funda uma dialética irrevogável, pois é produzido a partir de uma impossibilidade de testemunhar, de dar voz ao inominável, àquilo que no Lager tornou
} 
tema, o narrador pergunta-se "é isto uma voz?", quando, de fato, sua caracterização hesita sobre o estatuto de humanidade atribuído à fonte deste som inarticulado e monótono. Assim, um feixe descritivo tenta aproximar-se desta estranha voz: "sollozo canturreado", "estertor acompasado", "rapsodia del más allá", "melopea fantasmal", "salmodia". Em oposição a esta sinonímia, cujo elemento comum é o tom monótono, "apenas perceptible", de uma voz "ronca, susurrada", vinda de uma região subterrânea, o narrador salienta a loquacidade e a presença radiante da agonia da morte. A voz da morte no campo é "inagotable", "inmortal"; sua língua: o yiddish; seu canto: uma oração fúnebre hebraica, o kaddish. Em La escritura o la vida, a morte da vida implica a vida da morte.

O narrador ainda repõe uma outra qualificação da voz: "Se trataba, no obstante, de una voz humana. Un canturreo gutural, irreal”. (p. 38) A voz, que petrifica o personagem-narrador e Albert, provém das profundezas da garganta, de um lugar sem palavras.

A narração da busca de Albert e do personagem-narrador por sobreviventes dentro do barracão do Campinho oferece-nos um paralelo descritivo significativo. A paralisia e a mudez dos personagens têm um paralelo com a situação dos oficiais do exército aliado. A imobilidade caracteriza tanto o estado dos mortos, quanto o estado dos sobreviventes e dos soldados aliados. A imobilidade dos mortos é "aterradora", a dos sobreviventes coloca-os "pasmados" e a referente aos soldados combina-se com o horror, o pavor: semelhanças variadas. Também os olhos dos mortos e dos soldados ecoam o horror: ambos "desorbitados". Os mortos, "con los ojos abiertos de par en par, desmesuradamente abiertos al horror del mundo, las miradas dilatadas, impenetrables, acusadoras, eran ojos apagados, miradas muertas." (p. 39) A cegueira, contígua aos lugares das três identidades a dos soldados como de fora, a dos sobreviventes como limiares, e a das vítimas mortas como do fundo -, também participa deste paralelismo gradativo. A homologia está presente também na figuração do eco do silêncio: o silêncio desconcertado dos oficiais de uniforme britânico, o silêncio atento do personagem-

indiscerníveis o digno e o abjeto, o homem e o não-homem, a vida e a morte. In AGAMBEN, Giorgio. Lo que queda de Auschwitz. El archivo y el testigo. Homo Sacer III. Trad. Antonio Gimeno Cuspinera. Valencia: Pre-Textos, 2000, 
narrador e de Albert e o "silencio pegajoso" dos mortos do Campinho. Todos estes silêncios, às vezes dissonantes, propagam o som emitido por uma mesma fonte, a morte no campo.

A reação de Albert ao ouvir a voz agonizante é descrita como se a "melopea fúnebre que hiela la sangre en las venas" e a glaciação das "miradas muertas" também se transmitissem à voz de Albert, que se torna "helada y queda": “_ ¿Has oído? - dijo Albert en un susurro. (...) _ ¿Qué es? - preguntó Albert, con voz helada y queda." (p.41) É como se ocorresse, portanto, uma ação em cadeia que partisse do morto, passasse pelo sobrevivente e ecoasse e se refletisse no outro. Tal ação corresponde à manifestação da vivência da morte, do Mal radical, essência da experiência dos campos de concentração nazistas, segundo a acepção do narrador. É neste sentido que o sobrevivente pode testemunhar pela "testemunha integral", posto que traz em si o contato com esta substância atroz cuja tendência é a de irradiar-se no corpo e na alma humana até possuí-los integralmente, cegando-os, calando-os, imobilizando-os por completo.

Aparentemente, a influência marcante do diálogo na cena principal deste episódio se oporia à sua ausência no episódio anterior, já que o personagemnarrador e Albert não mais esbarram no silêncio espesso da incomunicação. Uma análise mais detida, no entanto, mostra-nos que as indagações, dramatizadas por um diálogo que insiste no efeito do eco, problematizam o sentido do dialogar.

As perguntas e réplicas, que se desenvolvem entre o personagem-narrador e seu interlocutor para reconhecer a existência do sobrevivente agonizante, são interpretadas pelo narrador como um entendimento entre ambos que só confirmaria a presença inquestionável do sobrevivente agonizante. No entanto, a surpresa e a incerteza de Albert em contraste com as frases enfáticas, fáticas, constatativas e irônicas do personagem-narrador constroem um diálogo que aponta, contraditoriamente, para o caráter não-dialógico da manifestação da voz da morte no campo.

O esquema abaixo reduz e reproduz o movimento do diálogo desenvolvido entre Albert e o personagem-narrador:

$1^{\text {a }) ~ “ \_~ ¿ H a s ~ o i ́ d o ? ~-~ d i j o ~ A l b e r t ~ e n ~ u n ~ s u s u r r o . ” ~ P e r g u n t a ~(i n t e r e s s a d a) ~ d e ~ A l b e r t . ~}$ 
"No se trataba de una pregunta en realidad. Era imposible no oír. (...)" Apreciação (em off - marca da obviedade) do personagem-narrador.

“_ ¿Qué es? - preguntó Albert, con voz helada y queda." Pergunta (interessada) de Albert.

“_ La muerte - repliqué - ¿quién sino?” Resposta fática (marca da obviedade) do personagem-narrador.

“¿Pero para qué seguir insistiendo ante tamaña evidencia?” Apreciação (em off marca da obviedade) do personagem-narrador. (pp. 41-42)

$2^{\mathrm{a}}$ ) “_ ¡Yiddish! - exclamó - ¡Habla yiddish!” Exclamação (surpresa) de Albert.

"_ Es la oración de los muertos - dice en un susurro." Afirmação (surpresa) de Albert.

"Me encojo de hombros. Pues claro que es un canto fúnebre. Nadie espera que la muerte vaya a machacarnos con canciones divertidas. Tampoco con palabras de amor." Apreciação (em off - marca da obviedade) do personagem-narrador. ( $p$. 43)

$3^{a}$ )"_Espérame aquí - dice Albert, perentorio -. ¡Voy corriendo al Revier a buscar una camilla!" Ordem e exclamação (interessadas) de Albert.

"_Te ocupas de él, ¿vale?" Ordem (irritada) e pergunta (fática) de Albert.

"_ ¿Y qué quieres que haga? ¿Le doy conversación? ¿Le canto una canción, yo también? ¿La paloma, quizá?" Resposta em forma de pergunta fática (marca da obviedade) do personagem-narrador.

“_ ¡Te quedas a su lado, nada más!” Resposta fática, irritada (reiterativa) de Albert. (p. 44)

A narração do diálogo tenso entre ambos suspende-se quando o personagem-narrador permanece ao lado do prisioneiro judeu agonizante, esperando a volta de Albert com alguma assistência médica. Por meio dos modalizantes de certeza - "sin duda", "ante tamaña evidencia", o narrador nos quer fazer crer que suas palavras e o gesto irritado de Albert coincidem com a evidência da presença da morte. Porém, não nos parece tão claro que Albert tenha se irritado com a obviedade da presença da morte. Inclusive, a resposta constatativa do personagem-narrador parece ter provocado uma irritação em seu 
interlocutor em razão da circunlocução que ela guarda. Albert toma a generalização e a abstração das respostas do personagem-narrador como uma zombaria indevida. Não se trata, pois, digamos assim, de uma tautologia, como nos quer convencer os comentários do narrador. O silêncio subseqüente do personagem-narrador comporta este constrangimento: “¿Pero para qué seguir insistiendo ante tamaña evidencia? El gesto de Albert parecía querer decir esto. ¿Para qué, en efecto?” Callé” (p. 42) A surpresa de Albert quanto ao yiddish destoa do pensamento impassível do personagem-narrador ou mesmo do comentário irônico do narrador: "A fin de cuentas, que la muerte hablara yiddish no tenía nada de sorprendente. Era una lengua que forzosamente había tenido que aprender esos últimos años." (p. 43) Assim, o diálogo entre ambos desenvolve-se numa contraposição de vozes em que o suposto caráter axiomático da situação é negado ao revelar, ao contrário, uma dissonância entre as duas vozes. Que se possa escutar e compreender a voz da morte no campo não é tão óbvio assim e essa dificuldade é representada num diálogo cujo desentendimento entre os interlocutores se dá, contraditoriamente, através da repetição da voz da morte. 0 eco constitui a ausência de comunicação e diálogo, o desentendimento essencial objetivado na reprodução e repercussão das palavras monológicas.

A evocação irônica do personagem-narrador da canção La paloma para Albert introduz no capítulo o discurso intertextual através da transcrição em alemão da canção infantil popular européia. Enquanto cuida do sobrevivente agonizante, o personagem-narrador põe-se a lembrar do soldado alemão que a cantava e fora morto por ele e Julien, seu amigo de Resistência. A narração de sua participação na morte do soldado das forças de ocupação nazista encaixa uma história que representa a impossibilidade de a inocência dialogar com as catástrofes históricas de nossa época. O personagem-narrador e seu companheiro Julien, numa ação de Resistência, deparam-se com o soldado alemão à beira do rio e resolvem matá-lo a tiros quando o soldado começa a cantar La paloma, o que faz o personagem-narrador evocar sua infância e hesitar antes de disparar: "La infancia, las criadas que cantan en los lavaderos, las músicas de los lugares de veraneo. ¡La paloma! ¿Cómo no iba a sobresaltarme escuchando esa canción?” 
(p. 46) La paloma, símbolo da paz, significa a inocência que subitamente reveste a imagem do inimigo e que é fruto de uma projeção e emoção subjetiva do personagem-narrador, incabível no contexto das guerras modernas, impessoais, tecnológicas e científicas. A idéia descabida de cantar ao agonizante La paloma faz evocar uma inocência fora de lugar. Tais vozes falam de um tempo de ruína, no qual inocência e vida não dialogam, cedendo lugar à voz do impacto e da morte. A memória, feita de ruínas, dá ouvido a estas vozes e cantos perdidos num tempo de perdas, através da voz da memória, da escuta e da escrita.

Além disso, a história encaixada mantém uma dupla relação de paralelismo antitético com a ação central do salvamento. Primeiro, o personagem-narrador realiza a ação de matar, abertamente contrária à de salvar a outrem. Segundo, a condição do judeu prisioneiro à beira da morte opõe-se à liberdade vivaz e descontraída do alemão à beira do rio, em Semur-em-Auxois. Há, no entanto, uma relação menos evidente de homologia entre as duas ações antitéticas, a de salvar e a de matar. A ação do personagem-narrador, por um lado, é motivada e justificada pelo narrador por uma intenção ideológica de livrar o mundo do avanço nefasto das forças nazi-fascistas; por outro, o abatimento do oficial alemão significa também para ele sua própria queda e degradação moral e humana.

Os fragmentos que recheiam o intervalo de espera do personagem-narrador pela chegada de assistência buscada por Albert recuperam as vozes de companheiros mortos, de outras mortes. Por exemplo, a de Hans Freiberg, "personaje de ficción" em El desvanecimiento ${ }^{51}$, que ocupa a de Julien, "personaje real”. A explicação que o narrador dá sobre a invenção de Hans Freiberg revela a sua concepção dialética sobre a relação entre realidade e ficção. Tal dialética neste capítulo está condicionada ao leitmotiv do eco enquanto reprodução intertextual de vozes. Segundo o narrador, o personagem fictício é produto de um sonho coletivo e inscreve-se também em El largo viaje para "encarnar" seus amigos judeus reais. Os palimpsestos, as repetições, as citações corroboram a

\footnotetext{
${ }^{51}$ El desvanecimiento, título original L'Évanouissement, obra de Semprún que teve pouca tiragem e repercussão na Espanha, é incluída por alguns críticos no ciclo de obras sobre Buchenwald do autor.
} 
dialética entre ação e dicção ${ }^{52}$, recuperam vozes perdidas, atos reiterativos e retificadores, numa tarefa discursiva infinita de contar toda esta morte.

As rememorações do narrador apresentam-se como lembranças do personagem-narrador. A certa altura da narrativa, o personagem-narrador, perdido em suas lembranças, percebe que não ouve mais o kaddish emitido pelo agonizante. Ele então preocupado debruça-se para ouvir o coração do exprisioneiro moribundo. O bater do coração do prisioneiro auscultado - "algo muy apagado y muy lejano: un rumor que se agota y se esfuma" (p. 50) - junta-se ao "rumor del viento que sopla, como siempre, en esta ladera del Ettersberg." (p. 50) Tais sons o fazem evocar imagens das latrinas coletivas do Campinho que reverberam os sons desta morte. ${ }^{53}$ Lugar pestilento, nauseabundo, as latrinas repeliam os SS e os Kapos, permitindo que os prisioneiros se refugiassem nelas contra a opressão sistemática exercida em Buchenwald. Segundo o narrador, era nas latrinas do Campinho que se criava "algo de vida", um "mercado de ilusiones y de esperanzas", um "zoco", uma "ágora en fin donde intercambiar unas palabras, calderilla de un discurso de fraternidad, de resistencia." (p. 53) Neste mercado heterogêneo, o narrador conta-nos como as palavras transformavam-se em moeda cujo valor se associava a um bem raro no campo de concentração, a fraternidade. A fraternidade aqui deriva do discurso dialógico, habita o mercado livre de palavras diversas e opõe-se à repetição monótona do eco.

Entre idas e vindas do personagem-narrador, entre lembranças de vozes perdidas e o impasse de ouvir a voz do ex-prisioneiro judeu que se perdia, o personagem-narrador ajoelha-se junto ao sobrevivente. Neste ato, ele se lembra de Maurice Halbwachs. A narração compara os últimos momentos de vida de Halbwachs, que não pôde ser salvo, com a situação de espera do prisioneiro judeu, mostrando a impotência que o personagem-narrador experimentou nas

\footnotetext{
${ }^{52}$ Segundo Lisa Block de Behar, ação ou dicção conforma uma falsa alternativa que permeia uma discussão de cunho filosófico e adentra no campo de reflexão das formas de representação artísticas. In BEHAR, Lisa Block De. Una retórica del silencio - funciones del lector y procedimientos de la lectura literária. MéxicoDF.: Siglo Veintiuno, 1984.

${ }^{53}$ Para conhecer informações de testemunhos da história do Campinho em Buchenwald, ler $O$ relatório Buchenwald - o dia-a-dia em um campo de extermínio nos depoimentos dos sobreviventes. IN HACKETT, David A.. (org.) "A libertação do campo", O relatório Buchenwald - o dia-a-dia em um campo de extermínio nos depoimentos dos sobreviventes. Trad. Maria Luiza e A. Borges. Rio de Janeiro-São Paulo: Record, 1998, p. 441-465.
} 
duas situações. Segundo o narrador, Maurice Halbwachs não havia recorrido à oração judia para celebrar sua morte, pois não havia tido a possibilidade de desejar fazê-lo. $O$ texto explora ironicamente a figura de Cristo e o léxico religioso ligado a este mito cristão ocidental:

"Me he arrodillado junto al superviviente judío. No sé qué hacer para mantener con vida a mi Cristo del kaddish. Le hablo quedamente. Acabo estrechándolo entre mis brazos, lo más ligeramente posible, por temor a que se me deshaga entre los dedos. Le imploro que no me juegue esta mala pasada, Albert no me lo perdonaría." (p. 54, o itálico é nosso).

As palavras sublinhadas reproduzem uma situação de prece, que nos remete à etimologia de precário: do latim precarius, "obtido por meio de prece; dado por complacência". A prece aponta para o precário, pois significa uma repetição de palavras na busca da salvação, uma tentativa de inscrever-se no sagrado, num mundo não mais precário. O narrador nos conta que dois dias depois da morte de Halbwachs, no seu trabalho no fichário do campo, ele apaga o nome e senhas de identidade do professor, deixando sua ficha "virgen y blanca", para que se pudesse inscrever nela "otra vida (...) una muerte nueva". Atos de escritas palimpsésticas, de inscrições e rasuras sucessivas de textos e identidades, reiteram a continuidade de uma morte sem fim.

A ação de salvamento parece ter sido concluída no oitavo fragmento do capítulo, apesar de a sobrevivência do judeu de Budapest ser enunciada sem certeza: "no es imposible que consiga salvarse", diz o personagem-narrador. Então ele pergunta a Albert se conhece André Malraux. O companheiro respondeIhe indignado que obviamente o conhece, uma vez que trabalhara no "Estado Mayor de Kléber", junto às Brigadas Internacionais na Espanha. E acrescenta: "_ Por eso me convidó Kaminski a su reunión, el invierno pasado..." (60) O personagem-narrador replica: “_ ¡Precisamente por esa reunión se me ha ocurrido pensar en Malraux!" (p. 60) Em seguida, o diálogo cede lugar à narração do testemunho de um sobrevivente do Sonderkommando de Auschwitz, ouvida no pavilhão de contagiosos da enfermaria. Kaminski, combatente das Brigadas Internacionais na Espanha, havia organizado a reunião. 
Os elos que a narrativa traça entre a evocação de Malraux, a luta contra as forças nacionalistas de Franco, Kaminski e o testemunho do sobrevivente do Sonderkommando de Auschwitz conduzem o leitor a pensar na associação livre de pensamentos e lembranças. No entanto, podemos observar a presença de outra lógica ligando tais "fortuitas" situações. As reticências que encerram a menção de Albert sobre a audiência do testemunho do sobrevivente do Sonderkommando de Auschwitz patenteiam essa lógica. As lacunas de informação vão preenchendo o relato mediante os silêncios dos personagens envolvidos. Desta maneira, ao fazer um sumário das circunstâncias em que se reuniam no Revier, o narrador diz ignorar a profissão de Ludwig G., responsável pela enfermaria. Informa-nos que sua profissão era omitida pelo mesmo. Além disso, chegamos a saber que Ludwig G. era um comunista alemão que havia sido registrado no campo como criminoso comum. Seu crime tampouco era conhecido. Ou seja, sua identidade de comunista era assim velada e sua identidade de criminoso comum possibilitava ao aparelho clandestino colocar um membro seu numa posição estratégica dentro do sistema concentracionário. Igualmente o narrador afirma não saber o que era o Sonderkommando e não se lembrar do nome do sobrevivente judeu polaco, se ele sequer havia sido mencionado por Kaminski.

A par de acentuar o silenciado, o discurso narrativo recorre a imagens em que figura a noção de "fundo": o lugar da audiência do testemunho, uma sala no "semisótano" da barraca de contagiosos; a "nieve profunda" despegada da sola dos tamancos dos prisioneiros ao entrar no recinto. Imagens reforçadas pela descrição da voz da testemunha do Sonderkommando: voz áspera que se faz densa quando toca nas profundezas da memória emocional. Por trás da imobilidade de suas mãos e da dureza de sua postura, o narrador flagra na voz da testemunha "emociones demasiado fuertes, como olas de un mar de fondo que removieran la superficie de aguas aparentemente tranquilas". (p. 63, o itálico é nosso) A audiência, submersa na escuridão deste relato angustiado, é surpreendida por um fim "provisional, sin duda, incluso aleatorio", somente definido pelo "agotamiento de nuestra capacidad de escuchar." A narração do 
testemunho do sobrevivente do Sonderkommando não nos informa o que foi contado aos prisioneiros, fala-nos de todo o silêncio que o acompanhou e do silêncio final com que as palavras de Kaminski sobre a culpa alemã foram recebidas. Nós leitores saímos do estado de ignorância sem chegar a conhecer o que foi dito. Compreendemos que aquilo que se situa no fundo, a voz da morte nos campos de extermínio, é transmitida a nós mediante o silêncio que imprimiu no ouvinte que dela nos fala. A imobilidade acompanha esse silêncio como índice do Mal:

"El superviviente del Sonderkommando de Auschwitz, aquel judío polaco que no tenía nombre porque podía ser cualquier judío polaco (...) permaneció inmóvil, con las manos descansando en las rodillas: estatua de sal y de desesperanza de la memoria.

Nosotros también permanecíamos inmóviles." (p. 65)

A partir desta história encaixada, outros silêncios propagam e antagonizam com o silêncio que o Mal do campo inscreve na testemunha e nos ouvintes. A narração do episódio da tortura nas salas de interrogatório da Feldgendarmerie surge como uma lembrança do personagem-narrador enquanto escutava o relato do sobrevivente no Revier sobre as câmaras de gás. Ele se lembra de La lutte avec l'ange de André Malraux, livro que compartilhava a leitura com Michel $\mathrm{H}$., companheiro de Resistência detido pela polícia secreta fascista. Na narração do episódio, Michel H. figura no silêncio do personagem-narrador. Uma história inclusive já contada, como presume, sem certeza, o narrador.

Ao entrar na sala de interrogatório, o personagem-narrador reconhece os objetos de seu companheiro, entre os quais estava o livro de Malraux, La lutte avec l'ange, não visto diretamente, mas relembrado na escuridão da memória. 0 interrogado nega conhecer os objetos e a fotografia do companheiro, empregando uma expressão do léxico da percepção auditiva: "_ No - digo -, no me suena de nada." (p. 68) Da mesma maneira, os agentes da Feld procuram retirar-Ihe informações através de perguntas armadilhas. A situação fraudulenta ressoa no uso da linguagem. O silêncio fraterno do personagem-narrador diante dos agentes da Gestapo constitui um ato de dicção cuja finalidade seria a de salvar a vida de Michel. 
Esta forma de silêncio, pautada na esperança, é comparada implicitamente pelo narrador com o tempo que separa as primeiras meditações de André Malraux sobre a relação entre o Mal absoluto e a fraternidade, contidas nos seus primeiros escritos de La lutte avec l'ange, das suas últimas em Le miroir des limbes, trinta anos depois, justamente quando o escritor "se codeó con la muerte". Os anos de silêncio do narrador assim são anunciados como ecos fraternos de sua experiência do Mal absoluto através do paralelo antitético que faz com o processo de reflexão e escrita de André Malraux. O narrador comenta que a obra fictícia de Malraux de certo modo antecipa a realidade das câmaras de gás nos campos nazistas e que em Le miroir des limbes o escritor retoma o acontecimento do ataque com gás alemão em Bolgako, em 1916, para refletir sobre acontecimentos posteriores como os campos de extermínio nazistas. O trecho da obra de Malraux transcrito pelo narrador nessa digressão servirá de fundamento filosófico para 0 narrador pensar a essência da experiência vivida no campo:

\footnotetext{
"Pocos 'temas' resisten la amenaza de la muerte. Este pone en juego el enfrentamiento de la fraternidad, de la muerte - y de la parte del hombre que anda hoy en día buscando su nombre, que no es ciertamente el individuo -. El sacrificio prosigue con el Mal el diálogo cristiano más profundo y antiguo (...)

Y Malraux concluye: 'Si recupero esto es porque busco la región crucial del alma donde el Mal absoluto se opone a la fraternidad." (p. 66-67)
}

A dialética entre o Mal e a fraternidade é colocada no capítulo como um intertexto e uma digressão reflexiva do narrador. Em seguida ele comenta que naquela tarde de inverno, num domingo, em 1945, na sala de contagiosos da enfermaria de Buchenwald, ainda não conhecia esta reflexão de André Malraux. O intertexto reflexivo do narrador sobre o Mal do campo entra em tensão com o tempo do mundo narrado, mostrando que as condições e o conhecimento do personagem-narrador, naquele momento da história, não permitiam que ele elaborasse sua experiência do modo como é apresentado por esta forma discursiva. A digressão intertextual do narrador sobre a dialética entre o Mal e a fraternidade submete-se, portanto, ao motivo do capítulo, qual seja, a dialética entre a perda e a recuperação, a salvação das vozes como eco da vivência da morte no campo. Inclusive, o fragmento intertextual de Malraux também é uma 
recuperação de sua obra La lutte avec l'ange quando Malraux estava entre a vida e a morte, entre salvar-se e perder-se. Através desta informação, o narrador relaciona as reflexões sobre a fraternidade e o Mal absoluto com a vida e a obra de Malraux:

\footnotetext{
"Siempre me ha parecido una empresa fascinante y fastuosa la de Malraux trabajando una y otra vez la materia de su obra y de su vida, ilustrando la realidad mediante la ficción y ésta mediante la densidad de aquélla, con el fin de destacar sus constantes, sus contradicciones, su sentido fundamental, a menudo oculto, enigmático o fugaz." (p. 66)
}

A narrativa ilustra a dialética entre ficção e realidade sublinhando que a ficção muitas vezes revela o essencial da realidade, suas contradições ocultas, através da recuperação de textos que refletem sobre o que foi silenciado na vida.

A impressão de que "una extraña continuidad, una coherencia misteriosa pero radiante gobernaba el devenir de las cosas" (p. 69) influencia a composição do capítulo, no qual se representa como o Mal radical ora se perpetua em ecos de vozes e silêncios que negam o diálogo com a vida, ora se contrapõe a vozes e silêncios de fraternidade que buscam resgatar e restaurar vozes silenciadas entre a vida e a morte, vozes recuperadas na e pela escrita em forma de intertextos.

O décimo fragmento finaliza o capítulo com o silêncio fraterno entre o personagem-narrador e Albert. Sentados ao sol, o personagem-narrador conversa com Albert sobre o episódio do ataque com gás, em 1916, às margens do Vístula, "que constituye el núcleo tenebroso de la novela" de Malraux. Albert lhe pergunta se sabe o que aconteceu com Malraux. Entre essa pergunta e a resposta, a narrativa interpola a descrição da paisagem que os personagens contemplam: a planície do Turingia, onde a poucas centenas de metros há um povoado cujos "habitantes (...) gozan sin duda de una vista inexpugnable sobre el campo." (p. 70) A "extraña premonición" do horror realizada na ficção de Malraux é contraposta à visão omitida pelos habitantes do povoado.

O narrador conta-nos que Malraux lutava na França com o pseudônimo de Berger e que isto lhe faz dar uma gargalhada ao pensar na coincidência entre o pseudônimo adotado pelo escritor no comando de um grupo de Resistência e o nome de seu protagonista no romance citado. Comenta ainda que Henri Frager, 
que Ihe havia informado sobre Malraux, não conhecia La lutte avec l'ange, mas que por ter organizado e dirigido uma das redes Buchmaster mais ativas da França, "sus lagunas literárias" podiam ser perdoadas. Tais narrativas de narrativas são silenciadas neste diálogo pelo personagem-narrador que as considera desnecessárias depois "del ruido y de la furia de las últimas semanas de Buchenwald, después del canto ronco del kaddish." (p. 71) O "bien valioso de ese silencio fraternal" ecoa nas histórias encaixadas deste capítulo, em seus intertextos líricos e filosóficos, como forma de ação em face da loquacidade da morte que reduz a fala do outro ao silêncio anônimo de tantos.

Nestes dois primeiros capítulos, a narrativa empreende uma busca dialética da visibilidade e da audição possíveis da vivência da morte no campo através da representação da cegueira e do eco como efeitos diretos que ela produziu no sobrevivente. Como torná-la visível e audível, sem que sua "oscura radiación" cegue mortalmente seu vidente e sua loquacidade petrifique seu ouvinte, constitui um problema de sua representação objetivada por uma fragmentação discursiva dialética que comunica as dificuldades de superação dessa vivência e de sua transformação em experiência comunicável.

\subsection{As fronteiras do Mal: a ausência de perspectiva e a perspectiva da ausência}

A ênfase do terceiro capítulo do livro, "La línea blanca", recai sobre as fronteiras imprecisas entre a liberdade e a prisão/opressão, o velho e o novo, a fraternidade e o Mal, a visão e a audição, o familiar e o estranho, dentro e fora do universo do campo de concentração. $O$ fato histórico objetivo da libertação de Buchenwald não implica um novo mundo livre do Mal para o sobrevivente. Enquanto dorme no campo, numa manhã (imprecisa) entre 14 e 19 de abril de 1945, o personagem-narrador é despertado pelo megafone por ordem de Anton, um prisioneiro alemão encarregado da biblioteca de Buchenwald, exigindo que ele se apresentasse imediatamente para entregar os livros em sua posse. Contrariado com a ordem, ele discute com o ex-bibliotecário a razão da devolução, já que a 
biblioteca e o campo tinham seus dias contados. Anton, o ex-bibliotecário, alega a necessidade da permanência dos livros, da biblioteca e do próprio campo de Buchenwald na tarefa de reeducar os nazistas. Anton pensava continuar trabalhando como bibliotecário no "novo campo de Buchenwald", pois seus parentes estavam mortos. O episódio termina com o personagem-narrador recitando o poema La liberté de René Char, descoberto no dia seguinte à libertação numa conversa com um dos oficiais das forças aliadas a respeito do paradeiro de um prisioneiro.

A ação representa a ausência de perspectiva dos sobreviventes diante do novo contexto histórico. A recitação do poema La liberté significa um desenlace da tensão da ação que aponta para a expressão solitária, impotente, de uma liberdade precária, conquistada em meio a um conflito de forças contraditórias. Os fragmentos encaixados reiteram o sentido de um mundo novo sem perspectiva de liberdade. A fusão com o desastre revela-se na ausência de perspectiva tanto para quem saiu do campo de concentração quanto para os de fora que viveram a guerra, mas não tiveram "perspectiva" do que ocorreu nos campos. No movimento dialético da obra, ocorre o estranhamento com os companheiros de dentro, negando a situação de identificação do segundo capítulo do romance. A sinonímia e a polissemia, recursos que ressaltam as enganosas fronteiras entre os significados e os sentidos das palavras, são empregadas para problematizar o uso ideológico da linguagem, elemento que determina as falsas perspectivas de liberdade. A tensão discursiva se dá entre a narração e o discurso lírico que reforça a ausência de perspectiva de liberdade neste novo mundo de pós-guerra muito próximo ao da guerra.

O capítulo é composto por quatro fragmentos que, vistos separadamente em sua unidade, possuem formas distintas de construção. O primeiro fragmento constitui um quadro composto por indícios da visão e da audição. Depois do encontro com Anton, de frente ao alambrado do campo de concentração, o personagem-narrador observa o bosque com grandes árvores e percebe o vento soprando entre os galhos, enquanto ouve o som frágil e violento de uma música de acordeão tocada , "del otro lado de la plaza de recuento", por um russo, que the 
suscita a imagem do estremecimento "de trigales en la estepa sin fin". Ele caminha em direção à praça de recontagem, deserta, onde se encontra o retrato gigantesco de Stalin que surge no dia seguinte à libertação no frontispício de uma barraca de prisioneiros russos.

$\mathrm{Na}$ descrição do narrador, não só as altas árvores do bosque contrastam com a imaginação dos trigais rasteiros da estepe imensa e deserta, como também o vento que sopra entre os galhos distingue-se da tempestade em forma de valsa que estremece os trigais. O retrato de Stalin aparece tão repentinamente como soa a música do acordeão russo e possui uma semelhança "inquietante" com a figura real do líder russo. A narrativa destaca o ultra-realismo mimético deste retrato e acrescenta que ele havia sido erguido como um totem protetor dos limites de um povoado primitivo. Tal retrato do narrador do retrato de Stalin sugere-nos a presença de forças irracionais e míticas que impulsionaram sua feitura e que constituem a fonte de uma identificação eficaz para o empreendimento da violência perpetrada pelos Estados totalitários em nosso século $x^{5} .^{54} 0$ personagem-narrador sente-se vigiado por esta "imagen tutelar del Generalísimo" ao mesmo tempo em que contempla o bosque no exterior de Buchenwald. A imagem de Stalin, comparada a uma construção primitiva, gigantesca, desmedida como as forças da natureza do bosque, leva-o a sentir uma espécie de autoalienação. Assim, a imaginação dos trigais estremecidos e subjugados na imensa estepe conjuga-se com a descrição do desenho de Stalin: os jovens russos de Buchenwald que pintaram e ergueram o retrato, frágeis e violentos como sua música, mostram-se subjugados aos seus próprios medos e necessidades primitivas e bárbaras.

A música do acordeão russo e o retrato de Stalin conformam imagens metonímicas e metafóricas que anunciam a ação representada no capítulo. $O$ quadro inicial do episódio revela o sentido aporético de uma liberdade sentida como precária e tênue por um recém ex-prisioneiro de um campo de concentração

\footnotetext{
${ }^{54}$ Semprún insinua uma interpretação que se identifica com a tese defendida por Theodor Adorno em Dialética do esclarecimento, analisada por Jeanne-Marie Gagnebin em seu texto "Sobre as relações entre ética e estética no pensamento de Adorno". In GAGNEBIN, Jeanne-Marie. "Sobre as relações entre ética e estética no pensamento de Adorno" in Lembrar escrever esquecer. São Paulo: Editora 34, 2006, p. 83-96.
} 
nazista. Os motivos do retrato de Stalin e da música do acordeão russo têm como pano de fundo, problematizado sob o ponto de vista do presente da enunciação, um mundo mais vasto em que forças históricas contraditórias se abatem sobre o personagem-narrador.

É no segundo fragmento que a construção épica do episódio da devolução dos livros coloca-nos o drama e as incertezas do sobrevivente sobre sua condição de liberdade. O diálogo com Anton é modelado em presente verbal e comentado pelo narrador. A ação se desenrola mediante uma discussão que falseia a realidade: o cumprimento de uma ordem particular, a de devolver os livros à biblioteca, reproduz uma ordem maior, a da continuidade do sistema opressivo concentracionário. A ordem de devolução dos livros é proferida por um espírito diligente e maníaco, o do bibliotecário, fruto de uma prática administrativa e política controladora, a do nazismo e do Estado moderno. O sentido da ação repousa sobre a usurpação e a fraude. O personagem-narrador sente-se usurpado pelo fato de um companheiro de campo exercer um poder ilegítimo e alienado: o de proteger os bens culturais da sociedade alemã através de sua posição decadente de bibliotecário de uma biblioteca por extinguir-se. O personagem Anton é tipificado sob a perspectiva crítica do narrador que enfatiza seu condicionamento comportamental e ideológico. ${ }^{55}$

O encontro entre o personagem-narrador e Anton reúne sucessivos desentendimentos. Primeiro, a voz "áspera, imperativa", gritada pelo megafone, envolve o personagem-narrador em uma "confusión mental", segundo a qual ele acredita continuar submetido "a las órdenes de los SS, al orden SS". O jogo de gênero entre as palavras "órdenes" e "orden" ${ }^{56}$ propicia comparar o gesto do exprisioneiro comunista às práticas autoritárias do sistema da S.S.. O estado

\footnotetext{
${ }^{55}$ Embora Anton seja apresentado em uma encenação que, atualizando o passado, reduz a distância estética segundo a qual a "contemplação tranqüila e segura" do autor intuiria sua generalização, os procedimentos de dramatização do passado e o encurtamento da distância estética, neste caso, dissimulam uma posição crítica acabada do narrador sobre o tipo de homem prisioneiro Anton e o ambiente e o conteúdo ideológico que contribuem para sua formação. Nossa análise do personagem-tipo de Semprún aqui tem como fundamento teórico a relação entre personagem e autor pensada por Mikhail Bakhtin. In BAKHTIN, Mikhail. "O tipo como forma de interação personagem-autor" in Estética da Criação Verbal. São Paulo: Martins Fontes, 2003, p. $167-169$.

${ }_{56}$ Em espanhol "el orden" significa o modo como algo se organiza, enquanto "la orden" significa a determinação de uma autoridade.
} 
confuso de consciência do personagem-narrador é acentuado pela proximidade cronológica entre o período de prisão e de liberdade. Ele se sente ainda condicionado às regras do campo.

Ao ouvir o epíteto "camarada" ao invés de seu número e reconhecer seu próprio nome, o desentendimento provisório do personagem-narrador entre 0 estado de liberdade e de prisão, entre vigília e estado onírico, desfaz-se. O narrador então expõe seus projetos para o dia que começava. Chama a atenção sobre tais projetos a restrição e a inversão de sua perspectiva: o mais global, visto como "un poco absurdo, excesivo al menos", concernia ao de "sobrevivir todavía ese día"; enquanto os "precisos, más limitados", porém "llenos de sentido, frente al otro que era insensato", consistiam em sair do campo, beber água fresca e reunirse com o grupo de jazz de Jiri Zak ao retornar. Apesar da libertação, a sobrevivência empenhada duramente a cada dia nos tempos de prisioneiro ainda se lhe apresentava improvável, a de maior alcance que se poderia ter. ${ }^{57}$

Alternando os recursos da sinonímia e da polissemia, o texto faz um paralelo com os motivos do fragmento anterior. A voz "imperativa" do bibliotecário alemão lembra-nos a "imperiosa necesidad" que impelia os jovens ex-prisioneiros russos a confeccionar o retrato de Stalin. A música "violenta y frágil" do acordeão russo e a imagem do "estremecimiento de los abdules en el viento" remetem à "violenta felicidad", ao "estremecimiento de toda el alma", que invade o personagem-narrador ao lembrar-se de sua nova liberdade. Em torno de sinônimos de "utilidad", "reprimir", "desaparecer" "de(volver)", a composição do diálogo leva quase ao colapso o significado literal destas palavras quando não contextualizadas. Segundo o bibliotecário, era "imprescindible" que "sin falta", ainda naquele dia, os livros fossem devolvidos à biblioteca, embora Anton não considerasse os próprios livros uma "lectura imprescindible". Na perspectiva do personagem-narrador, ele pretendia "seguir utilizando" os livros ausentes na

\footnotetext{
${ }^{57}$ A inversão de perspectiva de projetos produz o choque com nossas noções convencionais do sensato e do absurdo, do básico e do supérfluo. O discurso do narrador tende, assim, à negação da lógica vigente a fim de abrir ao leitor um horizonte de perspectivas invertidas, impensadas, imprescindíveis, no entanto, para a compreensão da lógica que presidia a vida no campo de concentração. A narrativa nos quer mostrar que esta lógica não se limita ao tempo e ao espaço do campo, pois perpassa a percepção subjetiva e as condições objetivas dos sobreviventes, após a libertação, representadas através de sua mudança dialética de "perspectiva".
} 
biblioteca, que desapareceria juntamente com o fim do nazismo e os campos. Mas, para o bibliotecário, "harán falta campos como éste" para a tarefa de "reprimir" os nazistas, de reeducá-los. Assim, os livros deveriam ser devolvidos, pois ele não pretendia voltar à casa, posto que todos os seus parentes tinham desaparecido. Anton sente-se mais útil na biblioteca do campo para a renovação da Alemanha.

Sob a diferenciação das perspectivas do personagem-narrador e do bibliotecário, a narrativa ilumina essa zona problemática na obra do bem e do mal. Anton é descrito como uma pessoa obtusa, presa ao senso comum, com manias de ordem, desconfiada, rígida. Suas sentenças categóricas, seus ares de superioridade, sua preocupação estrita com o desperdício material, seus métodos pedagógicos de reeducação caracterizam um personagem cujo comportamento, personalidade e idéias não distam muito daqueles que assinalam as tendências psicológicas e ideológicas do nazismo. Segundo tal construção, Anton possui certa paranóia ligada a um recalque de sentimentos, entrevisto em sua risada tensa e nervosa e na vontade de aplicar a mesma forma de violência contra os nazistas em nome de um projeto de "reeducação social". A seleção sumária que ele faz dos livros que ficariam no catálogo da biblioteca - ironicamente La voluntad de poder de Nietzsche desapareceria -, indica um pensamento utilitarista, uma vocação à censura, além de um dogmatismo e uma estreiteza de visão de mundo.

As contradições do ponto de vista do bibliotecário e do mundo que ele encarna são problematizadas pelo narrador num discurso que mostra as limitações ideológicas, de perspectiva de futuro e a farsa através de palavras que contêm armadilhas segundo seu contexto e uso. No diálogo, os livros "en su sitio", a "palabra justa" ou indevida, as "trampas dialécticas" são expressões que falam de uma zona movediça. Ao final do episódio, ao ver Anton afastar-se em direção ao fundo da biblioteca com os volumes de Nietzsche e Hegel que estavam em sua posse, o personagem-narrador pergunta-se se estariam "en su sitio". A respeito de Schelling, o narrador diz que

"El volumen suelto de sus obras que había en la biblioteca de Buchenwald contenía el ensayo sobre la libertad en el que Schelling explora el fundamento de lo humano. Un fundamento oscuro, 
problemático, pero, según escribe, 'sin esa oscuridad previa, la criatura no tendría ninguna realidad: la tiniebla le corresponde necesariamente en suerte'." (p. 78)

As idéias de Schelling são utilizadas pelo narrador para pensar o Holocausto. Na sua acepção a escuridão tinge essa zona da alma humana, a da liberdade, na qual o bem e o mal sob o signo lingüístico assumem múltiplas aparências que dificultam sua distinção: "La tiniebla del misterio de la humanidad del hombre, consagrada a la libertad, tanto a la del Bien como a la del Mal: henchida de esta libertad." (p. 78) A dialética entre a fraternidade e o Mal na obra assume na espiral deste capítulo o aspecto de seu leitmotiv: é introduzida e pensada como zonas cujas fronteiras são de difícil determinação. Além disso, é iluminada a partir do episódio de desentendimento com Anton: "Miraba alejarse a Anton y me preguntaba si esa idea de Schelling sería de alguna utilidad para reeducar a los antiguos nazis del futuro campo de Buchenwald." (p. 78) Com uma pergunta irônica e triste do personagem-narrador, o narrador finaliza o fragmento, ilustrando como o mal pode estar revestido do bem: como a perpetuação dos campos pode ser mascarada por "bons propósitos" como o de reeducar os nazistas. A narrativa problematiza como a pobreza de experiência e a falta de perspectiva de futuro podem engendrar o futuro da pobreza da experiência.

O terceiro fragmento encena um diálogo semelhante e elabora um tipo análogo, Nicolai. O personagem-narrador, ainda "sumido en el malestar de esa conversación" com Anton, diante do "retrato gigantesco de Stalin", na praça de recontagem, evoca seu encontro com Nicolai, perto do bloco 56, no dia seguinte à libertação. Nicolai tenta barganhar a arma que o personagem-narrador leva, oferecendo-lhe em troca dinheiro, roupas, álcool e mulheres. O jovem russo pensava ficar na Europa ocidental, vivendo de roubos e outros expedientes ilícitos, conseqüentemente sua metralhadora serviria ao grupo de bandoleiros que Nicolai liderava. Nesta negociação, Nicolai fala com orgulho da "perfeição" do retrato de Stalin que fizeram, em duas partes, com equipes diferentes, na noite de $11 \mathrm{de}$ abril. O personagem-narrador questiona-lhe a razão de se darem a esse trabalho no primeiro dia de liberdade. Nicolai zomba de sua falta de compreensão a respeito do sentido da construção do retrato. A ação representa a fraude. Nicolai 
procura apossar-se da arma do personagem-narrador em troca de bens materiais adquiridos por meio de embuste e violência. A fraude assume aqui contornos mais nítidos e alcance mais amplo: Nicolai, comparado ao General Stalin, representa a promessa de um novo mundo pautado em ideais comunistas que foram falseados. Aos olhos do personagem-narrador, os gestos, atos e palavras de Nicolai negavam a contra-ideologia marxista. A construção do personagem-tipo Nicolai é investida de uma crítica tenaz. Os comentários do narrador lamentam a debilidade da sua condição, naquele momento de sua vida, para compreender a realidade sócio-política de que Nicolai era exemplo. O encurtamento da distância estética através do presente verbal ajusta-se à representação da impossibilidade de distanciamento e esclarecimento do persoangem-narrador.

Nicolai trata Stalin como o "Gran Kapo" e justifica a realização do retrato dando o exemplo dos cultos religiosos da sociedade tradicional russa em que os ícones eram reverenciados quando a comunidade enfrentava grandes adversidades. Sob o ponto de vista do narrador, a veneração de Stalin por Nicolai e sua aspiração a chefe de um grupo de bandoleiros imitam tais práticas religiosas arcaicas de identificação coletiva e individual com forças originárias e supra-reais. As armadilhas das palavras são reiteradas na desconfiança que o personagemnarrador tem de que ao despedir-se Nicolai lhe faça uma finta e tome sua arma.

Os dois personagens-tipos iluminam ao mesmo tempo o universo concentracionário do qual não se separavam substancialmente e o mundo exterior no qual entrariam. Para Anton, o seu horizonte de mundo se restringia ao ambiente de Buchenwald, ao passo que Nicolai queria expandir a ambiência de Buchenwald ao mundo que ele queria explorar. Os projetos de futuro de ambos mostravam, contudo, uma relação com o mundo não muito diferente daquela achada no campo como estratégia de sobrevivência. Movendo-se entre homens "sem destino" 58 , rebaixados em sua estreiteza de consciência, degradados, como

\footnotetext{
${ }^{58}$ Fazemos uma alusão ao romance Sem destino de Imre Kertész. O romance centra-se nos episódios de sua experiência aos quinze anos de idade em Auschwitz e Buchenwald e representa a ruína do homem que sobrevive aos campos de concentração nazistas através de um final que mostra esse desencontro do homem saído do campo com o mundo ao qual retorna. O título faz jus à perda de perspectiva de futuro de quem vivenciou e sobreviveu à catástrofe. In KERTÉSZ, Imre. Sem destino. São Paulo: Editora Planeta do Brasil, 2003.
} 
dentro deste cenário degradante o sobrevivente podia conceber-se num espaço e tempo de liberdade? É este o sentido que subjaz à "La línea blanca", imprecisa e intransponível.

Ao final deste fragmento, Nicolai vira-se de costas para o personagemnarrador e caminha para o interior de seu espaço "privilegiado" de poder no campo, o bloco 56, da mesma maneira como Anton dirigiu-se para o interior da biblioteca, afastando-se dele. O virar-se de costas e o afastamento destes personagens são seguidos nos dois momentos de uma inflexão reflexiva aporética e crítica do personagem-narrador como se tal movimento lhe possibilitasse ver 0 anverso: o outro lado que as palavras e gestos dos personagens escondiam.

Esta reflexão aporética introduz o quarto fragmento, que volta ao momento chave do capítulo em que o personagem-narrador olha de frente para o retrato de Stalin. Sob a lembrança dessa visão, o narrador confessa os limites de seu entendimento, naquele momento, sobre o comportamento dos jovens russos de Buchenwald. Para o sobrevivente, o comportamento dos jovens russos representava um "enigma", parecia-Ihe "problemático", pois tais jovens não se assemelhavam aos "representantes auténticos de una sociedad nueva" tal como a idealizavam os jovens combatentes marxistas e intelectuais do campo como ele. Segundo o narrador, se ele pudesse ter enxergado "ese misterio del alma rusa, seguro que me habría ahorrado un largo rodeo, no carente de algún que otro oásis de valor y de fraternidad, por los desiertos del comunismo." (pp. 83-84) A imagem das fronteiras imprecisas entre o bem e o mal, "mistério da alma humana", explica o caminho que o narrador percorreu. Também ele procurou fazer com que a imagem da juventude russa se ajustasse aos seus ideais comunistas. $\mathrm{Na}$ perspectiva do narrador, a contradição entre a realidade e a idealização da mesma engendrou por sua vez os desertos do comunismo, o mal, que contraditoriamente também continha seu oposto, oásis de fraternidade. Para explicar o alcance limitado da visão do personagem-narrador, o narrador recorre ao conceito do desejo, que se contrapõe à razão. Explica que justamente porque estava imbuído mais de um desejo de futuro e menos de um desejo de compreender o presente, ele não pôde captar o verdadeiro sentido da nova sociedade comunista que se 
esboçava. Na perspectiva do narrador, o jovem sobrevivente que foi tampouco estava a salvo dos enganos e das ilusões de uma condição e de um contexto histórico que se caracterizavam pela dificuldade de discernimento e falta de perspectiva.

Em frente ao retrato de Stalin, pensando em Nicolai, o personagemnarrador vira-se de costas para o retrato e começa a recitar o poema "La liberté" de René Char. A narrativa então suspende o momento da recitação e encaixa o episódio em que o personagem-narrador leu por primeira vez o poema. Trata-se do encontro do sobrevivente, no dia seguinte à libertação, com um jovem oficial francês para informar-Ihe o paradeiro de Henri Frager. Nesta conversa, o personagem-narrador ensaia o primeiro testemunho sobre sua experiência em Buchenwald e descobre a poesia de René Char. O oficial francês empresta-lhe 0 livro de poemas de Char.

A extensão do fragmento equivale à soma dos outros três. À diferença das cenas com Anton e Nicolai, a evocação da conversa com o oficial francês, portador e mensageiro do poema de René Char, é tratada mediante o estilo indireto livre. Tal mudança de estilo prefigura a matéria nele disposta: o relato sobre a experiência em Buchenwald. O ganho no domínio da matéria é resultante da homogeneização do discurso narrativo, somada a um efeito de ambigüidade produzido pela alternância das vozes do personagem-narrador e do narrador, que se dissimulam uma atrás da outra. Mesmo o maior distanciamento do foco narrativo não é capaz de dissolver as incertezas do leitor que é conduzido da surpresa do jovem francês ao ato recitativo.

O personagem-narrador informa o jovem oficial francês da morte de Henri Frager, chefe da rede "Jean-Marie Action", para poupar-Ihe tempo de investigação. Ele o sabia graças ao seu trabalho no fichário de Buchenwald, através do qual a ordem de "entradas y salidas, de los muertos y los recién llegados" era mantida. À diferença do capítulo anterior, aqui o discurso do narrador acentua a inutilidade da oposição semântica entre entrada e saída do campo de concentração: inscrever e apagar, preso e liberado, "daba lo mismo", pois a ordem que imperava era a da destruição sistemática de seres humanos. Assim, os encontros com Henri Frager 
aos domingos em Buchenwald abrem o primeiro testemunho oral do sobrevivente cujo começo apenas esboçado é considerado pelo narrador inopinado ou incomum. Os domingos, o dia em que o Deus cristão descansa de sua obra, convertem-se para o narrador no "acceso más banal", mais profano ao inferno de Buchenwald e, contraditoriamente, aquele que não o banaliza por não repetir os suplícios cotidianos. O efeito no ouvinte, semelhante e contíguo àquele causado aos três oficiais das forças aliadas - "Se había sobresaltado, abriendo unos ojos desorbitados" (p. 86) -, confirma aos seus olhos o sucesso de seu primeiro testemunho, embora o narrador diga ironicamente o contrário. Para o narrador 0 fracasso é aparente, pois seu testemunho ao escapar do lugar-comum efetua uma suspensão dos referenciais culturais do ouvinte e foge de um entendimento "banal" do horror vivenciado: "Mi testimonio no correspondía al estereotipo del relato de horror que estaba esperando." (p. 88) A concepção de que só o incomum que a arte cria é capaz de comunicar o inimaginável do horror esboça-se na composição deste episódio. O novo que a arte almeja, a não repetição das convenções culturais e religiosas, contrapõe-se à atitude e ideologia que Nicolai e Anton representam.

Mas a perplexidade do seu primeiro ouvinte sinaliza principalmente a ignorância do mundo com relação ao universo concentracionário. Como saída da situação constrangedora, o personagem-narrador troca os papéis com seu ouvinte e começa a perguntar-Ihe sobre as novidades do universo artístico e literário ocorridas em Paris, durante sua reclusão. Ao contrário do oficial francês, ele não se surpreende com as informações do relato jornalístico e trivial de seu interlocutor. A narração comentada das informações do relato do oficial francês sublinha a morte de intelectuais como Jean Giraudoux, de Brasillach e Drieu la Rochelle, tratada como "desapariciones". A falta de novidades e os desaparecimentos no discurso do oficial francês apontam para a repercussão da destruição da guerra no mundo intelectual e das artes. Somente ao final do relato do oficial aparece a novidade da poesia de Char que retira o personagem-narrador do âmbito conhecido de referências literárias parisienses. 
Dando as costas ao gigantesco retrato de Stalin, o sobrevivente recita os versos de René Char. A voz, no início sussurrante, ganha força e a gritos libera aquilo que o discurso racionalizante, o logos, não havia podido ainda formular. O personagem-narrador termina a recitação sob a observação de um "soldado americano encaramado en su plataforma de vigilancia, con sus prismáticos dirigidos" a ele.

É lícito atentar para o paralelo entre o quadro construído no primeiro fragmento e sua transformação no ato declamatório de "La liberté". O discurso lírico que dispõe o ato de recitação do poema mimetiza e transforma, a um só tempo, os elementos sonoros e imagéticos que conformam o quadro que inicia a cena: a música do acordeão russo e o retrato de Stalin. Mimetizam-no na medida em que a poesia se apropria de tais materiais da realidade, o som e a imagem, para sua realização. Transformam-no porque o discurso poético supõe a musicalidade rítmica e melódica, como base material e orgânica, portadora de significação, e a imagem como fonte visual sobre a qual trabalha seu processo de simbolização. O processo de diferenciação que o poema recitado objetiva é tanto mais evidente se considerarmos que o narrador assemelha a música do acordeão russo e o retrato de Stalin à tempestade e a um ícone idolatrado, expressões de uma vontade arcaica de mimetização do homem com as forças primordiais da natureza num mundo ameaçador. A expressão poética opõe-se a essas respostas primárias ao articular o som e a imagem com o logos através do signo e do discurso. Além disso, a recitação de "La liberté" na finalização da ação do capítulo confere uma nova versão à sua estrutura: faz de sua prosa romanesca um símile da construção externa de uma poesia, a do próprio poema de René Char. ${ }^{59}$

\footnotetext{
${ }^{59}$ La liberté

Elle est venue par cette ligne blanche a pouvant tout aussi bien signifier l'issue de l'aube que le bougeoir du crépuscule. Elle passa les grèves machinales; Elle passa les cimes éventrées. Prenaient fin la renonciation à visage de lâche, la sainteté du mensonge, l'alcool du bourreau. Son verbe ne fut pas um avengle bélier mais la toile où s'inscrivit mon souffle. D'un pás àne se mal guider que derrière l'absence,
} 
O formato cíclico deste poema, que repete o primeiro verso no último, pode ser comparado com a volta cíclica que a narração executa, neste capítulo, ao retomar o início enquanto conclusão do quadro, o que o caracterizaria mais como um tableau. O ciclo aqui, porém, difere da idéia de círculo, pois o retorno impõe, tanto neste poema como na estrutura do capítulo, um avanço dialético, uma transformação do mesmo em um novo significado. $O$ ato de recitação não é um ato de pura repetição, pois o personagem-narrador interpreta o poema dando-lhe uma vida singular enquanto resposta subjetiva para uma situação objetiva de liberdade precária. A poesia é declamada por uma voz que "se eleva, se refuerza, se hincha" (p. 84), assim como se ergueu o retrato de Stalin e se inchou o acordeão russo. Mas o poema recitado vai além dessa assimilação primária e devolve ao personagem-narrador uma tentativa de elaboração dessa experiência. Jogando com as motivações do inconsciente e da razão, o processo lírico desta poesia possibilita-lhe uma compreensão da sua impotência compreensiva, uma perspectiva da sua ambiência desprovida de perspectiva, um consolo íntimo para um momento de indefinição, uma interlocução para uma voz sem auditório, um desabafo para um espírito angustiado e solitário.

"La línea blanca" significa o caminho pelo qual a liberdade chegou para um homem que vivenciou a catástrofe dos campos de concentração naquele momento de seu itinerário. Uma liberdade não conquistada heroicamente, mas alcançada após a renúncia à morte, após mentiras santas, embebida na embriaguez dos carrascos. Uma liberdade desgastada, imprecisa, turvada, que vem da ausência e repousa sobre a ferida. É disso que fala o poema de René Char cujo mote "serve" de título para este capítulo da narrativa.

\subsection{A tradução do Mal: a perda do sentido do regresso e a origem do sentido da perda}

elle est venue, cygne sur la blessure par cette ligne blanche a René Char Poemas en francés. Disponível em: $<$ http://poemasenfrances.blogspot.com/2006/02/ren-char-la-libert.html $>$. Acesso em 19 nov. 2008. 
A tradução constitui o princípio organizador do quarto capítulo, "El teniente Rosenfeld", e manifesta sua insuficiência na resolução da aporia da volta do sobrevivente ao mundo da liberdade. A tradução, dialeticamente, representa o caráter precário da linguagem para atender aos desejos de reintegração do sobrevivente e de transmissão de sua experiência ao mundo, ao mesmo tempo em que traduz a fusão do personagem-narrador com o mundo de Buchenwald. As idéias de causa e origem, transcurso e passagem, voltar e regresso, constitutivas do processo de tradução, tornam-se os elos entre as histórias encaixadas e o modo de reportá-las.

A ação representada é a da visita à casa de Goethe. No dia 23 de abril, dia de São Jorge, o tenente Rosenfeld do exército americano instalado em Buchenwald convida o personagem-narrador para um passeio por Weimar e uma visita à casa de campo de Goethe. A princípio, Rosenfeld e o personagemnarrador encontram a casa fechada. Depois, um vigia os recebe hostilmente, tentando impedir sua entrada. O paradoxo que envolve a ação da visita consiste no fato de o personagem-narrador sair do campo de concentração, voltar ao mundo exterior e sentir-se, no entanto, inapto à vida. Isso se exprime quando ao final da visita Rosenfeld sugere ao personagem-narrador "volver" ao campo de Buchenwald e este percebe que a palavra suscita-lhe uma estranha alegria que não pode ser compartilhada pelo tenente. Apesar de seu apreço por Rosenfeld, homem de olhar atento e voz sussurrante, capaz de escutar sua vivência, de sugerir-lhe formas de relatá-la, não ocorre uma identificação completa. Como negação do capítulo anterior do livro, o capítulo representa a identificação contraditória com um personagem de fora do campo envolvido no combate ao nazismo. Não compreender a ambigüidade de voltar implica um desconhecimento, um estranhamento, que determina a aporia da sobrevivência enquanto liberdade. Por outro lado, a reação hostil do guia da casa de Goethe com os visitantes também guarda uma relação com o leitmotiv da tradução, pois recupera o outro significado perdido da palavra hospitalidade, hostilidade. 
A cena central do capítulo envia-nos ao topos da paisagem amena: o personagem-narrador e o tenente Rosenfeld visitam a casa de campo de Goethe, num vale à beira do rio $\mathrm{Im}$, rodeado de "arboledas", sob um sol ameno, numa fresca manhã de primavera próxima, acompanhados pelo canto das aves. Voltar a ouvir o canto dos pássaros suporia a alegria, sentimento previsível neste tipo de cenário. Porém, a volta dos pássaros provoca no personagem-narrador um malestar inquietante e angustiante. O motivo da visita poderia ser identificado com a situação típica do reconhecimento do herói que retorna à pátria, ao seu mundo, após longa viagem em terras inóspitas e estrangeiras. Aqui, entretanto, ele é deslocado e ironizado. $O$ retorno à terra natal deste Ulisses às avessas conjuga-se com o mal-entendido da morte aparente, reinterpretado através da imagem do ressuscitado que não sente voltar ao lar ao menos como vivo. A representação literária enquanto tradução da realidade, submetida ao processo hermenêutico com base no qual se dá a praxis da tradução, determina, pois, a construção e a organização do capítulo. Já no primeiro fragmento, há um ato tradutório enunciado pelo narrador: "Hablamos en alemán (...) Desde el día en que nos conocimos, hemos hablado en alemán. Traduciré nuestra conversación para la comodidad del lector" (p. 93) A conversa com o tenente Rosenfeld é apresentada a nós como resultado de um ato tradutório do narrador dirigido ao leitor para facilitar-Ihe o caminho da leitura. Veremos como esta ingênua finalidade inicial é problematizada no decorrer do capítulo.

Três situações narrativas entrelaçam-se no segundo fragmento. Aparentemente, a apresentação do personagem Rosenfeld constitui o elo entre elas. Este nexo, no entanto, perde força quando penetramos no sentido que as atravessa. Observemos a relação entre a segunda e a terceira situação. $\mathrm{O}$ exprisioneiro recebe uma convocação do serviço oficial de informação do exército americano, que tinha por objetivo elaborar um relatório sobre Buchenwald, sendo assim interrogado pelo tenente Rosenfeld. Ao ser perguntado por sua profissão, ele sorri porque se lembra de sua chegada a Buchenwald. Toda a narração da chegada do personagem-narrador a Buchenwald e da inscrição de sua profissão, estudante de filosofia, na ficha de identificação dos prisioneiros do campo parece 
surgir da necessidade de elucidar ao tenente o motivo de seu sorriso. À primeira vista, a terceira situação depreende-se da segunda enquanto recordação do personagem-narrador, como associação da memória. Porém, o que nos informa o uso do pretérito mais que perfeito do indicativo é que ela se dirige antes ao leitor, representando, portanto, as reminiscências do narrador que conhece inteiramente o seu desfecho, ocultado a nós, leitores. A narração nos omite a informação, conhecida só no último capítulo do livro, de que o prisioneiro alemão ao preencher sua ficha de identidade modifica sua profissão para "estucador".

Ora, acontece que sucessivas ocultações e resíduos de informações são deixados na passagem de uma situação narrativa a outra como perdas de uma vontade de fidelidade inseparável de um ato de traição. $O$ riso do personagemnarrador ao tenente Rosenfeld esconde sua história da inscrição no momento de sua entrada em Buchenwald. Esta história narrada ao leitor oculta a troca de profissão em sua inscrição no campo, omitida, por sua vez ao personagemnarrador pelo velho prisioneiro alemão. Podemos entrever nesta progressão de informações desaparecidas uma acepção de tradução como tarefa que compreende a impossibilidade da equivalência plena entre as línguas, a inexorável convivência com perdas semânticas e fonéticas, isto é, com uma incompletude constitutiva. Acrescente-se a este processo implícito de tradução o fato de a troca de profissão surgir, de certa maneira, de um jogo de palavras do personagemnarrador ao traduzir sua profissão de estudante de filosofia ao idioma alemão:

\footnotetext{
"No pude evitar hacer un retruécano de estudiante germanista. Kein Beruf aber eine Berufung! Me sentí satisfecho con mi juego de palabras.

Una sonrisa iluminó brevemente el rostro serio del hombre que estaba estableciendo mi ficha de identidad." (p. 101)
}

Por um lado, esta troca improvisada de signos é valorizada pelo narrador que vê nela uma recriação original da mera informação primeira e seu domínio da língua alemã. A narrativa defende a liberdade do tradutor contra o servilismo ao texto original. A tradução inventiva que o personagem-narrador faz da estrita informação de sua profissão demonstra, por outro lado, sua ignorância sobre a insignificância da mesma para sobreviver nos campos de concentração: “_ ¡Aquí - 
dijo -, los estudios de filosofía no son una profesión conveniente! Aquí, más vale ser electricista, ajustador, albañil... ¡Obrero especializado, vamos!” (p. 101) O desconhecimento do funcionamento do sistema dos campos de concentração e a inocência dos seus vinte anos fazem com que escape ao personagem de então o sentido da mensagem emitida pelo prisioneiro alemão. A narrativa problematiza assim outro aspecto da tradução. A tradução não se reduz à sua função comunicativa. Ao contrário, depende de fatores psicológicos, existenciais, culturais e ideológicos que determinam sua validade.

Ademais, a troca de profissão representa a apropriação e a transformação de uma palavra, redundando num ato transgressor e solidário. É mediante uma dupla traição (traduttori traditori) - para com o significado das palavras Beruf e Berufung e para com o sistema de informações do campo - que o prisioneiro alemão expressa sua fidelidade humanista às possibilidades de sobrevivência do novo companheiro que chegava ao campo. A palavra original sobrevive à custa de um ato tradutório transgressor do significado original da palavra, assim como a sobrevivência da testemunha se deve em parte à sua transgressão tradutória do original.

Também a chegada ao campo de concentração pode ser analisada nesta chave dos aspectos teóricos e práticos da tradução como interpretação da experiência da catástrofe e de sua representação neste capítulo. A chegada ao campo é descrita pelo narrador como uma iniciação à vida nele: "Este hecho no había dejado de sorprenderme, encontrar a esos jóvenes forzudos rusos, (...) desde el primer momento de mi iniciación en la vida del campo." (p. 98) Como iniciação, ela aponta para o momento originário ou de transformação em uma nova identidade. A violência desta transformação para os sobreviventes dos campos de concentração é recorrentemente narrada em seus testemunhos. Em É isto um homem?, Primo Levi identifica o momento da chegada com a chegada ao fundo. ${ }^{60}$ Algumas características da chegada ao campo de Auschwitz

\footnotetext{
${ }^{60}$ O capítulo "No fundo" do seu livro traz uma operação hermenêutica da chegada ao lager como chegada ao fundo: "Num instante, por intuição quase profética, a realidade nos foi revelada: chegamos ao fundo. Mais para baixo não é possível. Condição humana mais miserável não existe, não dá para imaginar (...)” (pp. 2425). No capítulo, Primo Levi interpreta a chegada ao campo como uma descida aos Infernos, uma exclusão
} 
representada por Levi podem ser reconhecidas na descrição deste narrador sobre sua chegada a Buchenwald. ${ }^{61}$ Mas na situação do primeiro encontro com o tenente Rosenfeld, a chegada enquanto iniciação assume irônica e simbolicamente o sentido de Origem, na acepção que Benjamin Ihe atribui, a de um passado que se plasma no presente através de um processo de rememoração, restauração e revelação de conexões capazes de dar novo sentido e significação a ele. ${ }^{62}$ Assim, a chegada ao campo é metáfora de um texto original cuja potência semântica abrange suas possibilidades de tradução no futuro, sua sobrevivência, sob a força produtora de um regresso mnemônico ao idêntico que possibilita a passagem ao diferente. Num sentido dialético negativo, o texto de chegada da tradução sofre um processo de violência e de estranhamento para transformar-se em outro, o que faz dele uma metáfora da chegada ao campo de concentração.

O substrato semântico da tradução une o primeiro fragmento ao segundo mediante o que escapa à compreensão interpretativa do tenente Rosenfeld nos atos comunicativos com o personagem-narrador. Tanto a perturbação inquietante

total do mundo, uma perplexidade diante do absurdo e da loucura de uma realidade que se deixa apreender mediante sua face irreal. Seu estilo irônico, o ritmo acelerado e ágil de sua prosa, as várias alusões a componentes do drama definem uma versão da chegada que a assemelha a um teatro grotesco e fantasmagórico. Chegar ao fundo significa a destituição de toda e qualquer posse material ou espiritual, de todo e qualquer atributo que faça um ser humano pertencer à comunidade humana. Seu exemplo do mendigo assinala isso. A "vida nua" torna-se o corolário da condição descrita. O significado de "campo de extermínio" abre-se à sua mente em sua dupla acepção: ruína, destruição total, banimento e expulsão de uma zona do mundo e da vida humana. Se no capítulo "A viagem" P. Levi descreve a travessia para o inframundo - a alusão irônica a Caronte confirma esta leitura-, em "No fundo" assistimos à representação desta entrada, passagem e transformação. Após "chegar no fundo", a narração dá uma pausa e em seguida o narrador oferece-nos sua nova identidade: "Häftling: aprendi que sou um Häftling. Meu nome é 174.517; fomos batizados, levaremos até a morte essa marca tatuada no braço esquerdo." (p. 25) Uma identidade que é a perda de toda e qualquer identidade. Até o final do capítulo, ele descreve sua entrada nesta nova ordem dantesca "Qui non ha luogo il Santo Volto, qui si nuota altrimenti che nel Serchio!", "no limiar do inferno", "no umbral da casa dos mortos" -, onde o passado e o futuro não existem, onde as lembranças devem ser apagadas e a transformação significa impossibilidade de auto-reconhecimento. In LEVI, Primo. "No fundo" $\dot{E}$ isto um homem? Trad. Luigi Del Re. Rio de Janeiro: Rocco, 1988, p. 20-35.

${ }^{61}$ Tais como o jorro ininterrupto de uma prosa acelerada, o descompasso entre o tempo dos acontecimentos e o tempo de sua apreensão, o ponto de vista irônico contemplado na impressão de fazer parte de um espetáculo irreal, de ser objeto de "cerimonias rituales y purificadoras" primitivas... Toda uma apropriação de imagens de mundo oriundas da tradição cultural e literária ocidentais permeia os modos de representação e interpretação da vivência da "chegada ao campo de concentração" das testemunhas escritores, que, a nosso ver, vem constituir-se em um cronotopo das narrativas referentes à modalidade literária do testemunho da Shoah.

${ }^{62}$ Baseamo-nos na interpretação que Jeanne-Marie Gagnebin faz da noção de Origem de Walter Benjamin ligada à idéia da tradução. In GAGNEBIN, Jeanne-Marie. "Origem, Original, Tradução" in História e narração em Walter Benjamin. $2^{a}$ edição, São Paulo: Perspectiva, 1999, p. 14. 
do personagem-narrador diante dos pássaros quanto seu sorriso em face da pergunta do tenente sobre sua profissão fogem ao entendimento do oficial.

Depois de o personagem-narrador contar ao tenente o porquê de seu sorriso, Rosenfeld sugere a ele um começo de relato sobre sua experiência do campo. Esta entrada em matéria de Rosenfeld propicia que o sobrevivente encontre um interlocutor para discorrer sobre sua compreensão da experiência.

A "entrada en materia" reveste-se aqui da idéia de Origem. A representação do Holocausto trabalhada no romance sob a ótica da dialética entre ficção e realidade é conformada neste capítulo pelo leitmotiv da tradução. Na concepção do personagem-narrador, vários inícios oferecem-se como entrada na matéria, uma vez que este início não corresponde exatamente à origem cronológica da experiência. Como para ele só é possível uma aproximação da essência da experiência do campo, a Origem se identifica com a essência: “_ Hay muchas clases de buenos principios (...) Habría que empezar por lo esencial de esa experiencia..." (p. 102) A preocupação do narrador com o termo "essência" remete-nos à dialética entre essência e aparência, entre verdadeiro e falso, aspectos que orientam sua compreensão do Holocausto e de sua representação. Aproximar-se da essência significa dizer que a essência só pode ser apreendida em sua aparência, que a "verdade" não pode ser atingida em sua totalidade e que a origem cronológica coloca-se como uma mera aparência, assim como toda a linearidade dela decorrente, toda a seqüência cotidiana do trabalho opressivo, da fome, do frio. Contraditoriamente, é na aparência do sensível ou no sensível como aparência em que está encarnada a essência da experiência. É nos indícios da visão, da audição e dos signos lingüísticos carregados de ideologia da testemunha e do mundo exterior ao campo em que o Mal absoluto deve então ser decifrado e interpretado, conforme este sobrevivente testemunha:

"El horror no era el Mal, no era su esencia, por lo menos. No era más que el envoltorio, el aderezo, la pompa. La apariencia, en definitiva. Cabría pasarse horas testimoniando acerca del horror cotidiano sin llegar a rozar lo esencial de la experiencia del campo." (p. 103)

O desenvolvimento do diálogo entre os dois personagens neste episódio está entremeado de pensamentos e comentários do personagem-narrador que 
parecem estar em off como se fossem restos de um vazio comunicativo, transmitidos ao leitor. Além disso, poucos fragmentos no romance valem-se tanto do discurso reflexivo do mundo narrado como este. O nível intelectual e cultural do jovem sobrevivente contribuía para sua elaboração filosófica da experiência da catástrofe. ${ }^{63}$ Assim, conceitos como o "Mal radical" de Kant, o mal absoluto de Malraux, a liberdade problemática de Schelling e idéias de Heidegger participam da sua interpretação dialética sobre a essência da experiência, o Mal radical vivenciado "como una experiencia de la muerte". A erudição de Rosenfeld permite-lhe acompanhar o desenvolvimento do pensamento do sobrevivente.

A opinião do narrador de que a testemunha não pode ter acesso a uma compreensão objetiva e total da experiência em conformidade com a crença de que esta forma de conhecimento tampouco é capaz de dar conta da sua essência, constrói uma dinâmica dialética em que a testemunha torna-se o centro identitário das contradições entre objetividade e subjetividade, totalidade e parcialidade, aparência e essência, do mal perpetrado, o que a singulariza historicamente em sua extrema precariedade. É neste sentido que a frase de Schelling, mencionada

\footnotetext{
${ }^{63}$ Raúl Illescas analisa a presença da Literatura e, dentro dela, do universo filosófico em La escritura o la vida como uma chave de entrada para compreender a obra. Segundo o autor, os poetas e os pensadores com os quais o autor dialoga, citados ou in praesentia na obra, permitem-lhe refletir sobre a experiência do Holocausto e a possibilidade e o modo de narrá-la. No caso de Kant, Heidegger, Levinas, Santo Agostinho e Wittgenstein, Illescas afirma que formam um "espacio que le permite al narrador preguntarse una y otra vez por la condición del Mal Absoluto (...) por el horror planificado en el que estuvo inmerso" e representam "autoridades (...) para reflexionar sobre la condición de sobreviviente del narrador". O autor termina o texto da seguinte maneira: "la presencia de escritores, poetas, filósofos, de obras y lenguas en La escritura o..., logra reproducir la babel lingüística del campo de concentración de Buchenwald y le ayuda a responder al Rostpanier la angustiada pregunta adorniana después de Auschwitz." A idéia de buscar autoridade para sustentar sua reflexão sobre a experiência nos parece fundamental. Trata-se da tensão na literatura de testemunho entre o histórico e o literário, o real e o fictício, e da busca de legitimação da voz da testemunha no campo do discurso literário. $O$ espaço fronteiriço do testemunho literário constitui uma zona problemática em que as verdades objetiva e subjetiva se enfrentam na consciência da testemunha escritor que tem de atravessá-la para instaurar o lugar de enunciação de sua verdade. A testemunha escritor, por um lado, não abdica a pertencer a uma realidade histórica, ter vivenciado uma situação injusta de violência do Estado moderno, ter um compromisso ético com os companheiros que a compartilharam com ele. Por outro lado, sabe que a memória de sua vivência é falível, sua percepção da realidade corre riscos de deformação, seu juízo se confunde com os ressentimentos derivados da humilhação sofrida, sua razão e lucidez podem estar contaminadas de perplexidade, hiatos, criptas e paralisia. A verdade da testemunha escritor é uma verdade subjetiva e em crise que, não obstante, roga o estatuto e a autoridade de verdade histórica objetiva, ainda que em uma instância que, por tradição, não lhe é própria, a literária. In ILLESCAS, Raúl. "Jorge Semprún: $L a$ escritura o la vida. Holocausto y literatura" in LEMER, Isaías (ed.) NIVAL, Robert (ed.) ALONSO, Alejandro (ed.) Actas del XIV Congreso de la Asociación Internacional de Hispanistas, III: Literatura española, siglos XVIII - XX. Newark, DE: Cuesta, 2004, p. 317, 322.
} 
pelo narrador, sobre o "fundamento humano" expande o particular da condição da testemunha para o universal da natureza humana. Nesta esfera maior, a eternidade, a transcendência e o atemporal entram em relação dialética com a finitude, o transitório e a historicidade: "La ténèbre qui nous était éclue en partage. Que le ha tocado en suerte al hombre, desde toda la eternidad. O mejor dicho, desde toda su historicidad." (p. 103). Segundo o narrador, o que define a especificidade histórica da catástrofe Shoah reside na relação dialética entre o Mal e a fraternidade, que se realiza no reino da liberdade da ação humana enquanto possibilidade da alma humana que se repete diferentemente na História e que nos campos de concentração singularizou-se como manifestação absoluta do Mal:

"Lo esencial - digo al teniente Rosenfeld - es la experiencia del Mal. Ciertamente, esta experiencia puede tenerse en todas partes... no hacen ninguna falta los campos de concentración para conocer el Mal. Pero aquí, esta experiencia habrá sido crucial, y masiva, lo habrá invadido todo, lo habrá devorado todo... Es la experiencia del Mal radical..." (p. 103)

Para o narrador, o absoluto do Mal na Shoah tange o conceito de totalitarismo. Os campos de concentração figuram na obra como microcosmos do Estado totalitário. ${ }^{64}$ Além disso, o Mal radical da Shoah implica uma mudança qualitativa em termos históricos que radica no aspecto quantitativo do fenômeno, na realização massiva do mal ${ }^{65}$ : "No hacen ninguna falta los campos de

\footnotetext{
${ }^{64}$ F. Konder Comparato define como uma das características do regime totalitário a penetração de seu poder controlador em todas as esferas da organização da vida humana, coletiva ou individual, suprimindo assim a liberdade em todos os planos de sua ação, imaginação e expressão: "O que caracteriza o totalitarismo é o fato - sem precedentes na história - da destruição, por obra do poder público, das estruturas mentais e institucionais de todo um povo, com a concomitante tentativa de reconstrução, a partir dessa terra arrasada, de mentalidades e instituições novas. Daí por que, desde os anos 30 do século xx, já não era possível confundir o Estado totalitário com aquele simplesmente autoritário. (...) Ao contrário dos Estados autoritários, em que o povo não participa do poder político, mas onde a vida privada goza de certa autonomia, o Estado totalitário suprime a liberdade, individual ou grupal, em todos campos, exatamente porque, com a sua instalação, desaparece a distinção entre Estado e sociedade civil, entre a esfera pública e a privada." O Lager nazista e o Gulag soviético são entendidos pelo autor como "uma espécie de miniatura do Estado totalitário". In COMPARATO, F. Konder. "Experiência totalitária do século xx: lições para o futuro" in NOVAES, Adauto (org.) O avesso da liberdade. São Paulo: Companhia das Letras, 2002, p. 280-281.

${ }^{65}$ Semprún possui uma visão dialética da singularidade do mal perpetrado nos campos de concentração. Nesse ponto, por exemplo, a singularidade constrói-se a partir da dialética entre quantidade e qualidade. Essa visão é expressa por Adorno ao tratar desta catástrofe: "La capacidad para la metafísica está paralizada porque lo que ocurrió le destruyó al pensamiento metafísico especulativo la base de su compatibilidad con la experiencia. Una vez más triunfa, inefablemente, el motivo dialéctico de la conversión de la cantidad en calidad. Con el asesinato administrativo de millones, la muerte se convirtió en algo que nunca había sido
} 
concentración para conocer el Mal. Pero aquí, esta experiencia habrá sido crucial, y masiva, lo habrá invadido todo, lo habrá devorado todo... Es la experiencia del Mal radical..." (p. 103)

Por último, o personagem-narrador estabelece o vínculo entre o Mal radical e a experiência da morte. Uma nova contradição emerge neste vínculo contra as proposições da lógica formal. A idéia de que o Mal radical correspondente à morte ultrajante do campo vivenciada coletivamente deu origem a uma experiência fraterna pode parece-nos uma contradição chocante. No entanto, em La escritura o la vida, toda experiência possível do campo extrai-se justamente de sua negatividade extrema, que pode levar à morte de quem a vivenciou e sobreviveu:

\begin{abstract}
"- Y luego, de esta experiencia del Mal, lo esencial es que habrá sido vivida como una experiencia de la muerte... Y digo bien 'experiencia'... Pues la muerte no es algo que hayamos rozado, con lo que nos hayamos codeado, de lo que nos habríamos librado, como de un accidente del cual se saliera ileso. La hemos vivido... No somos supervivientes, sino aparecidos... Esto, por supuesto, sólo resulta decible de forma abstracta. (...) Pues no es algo creíble, no es compartible, puesto que la muerte es, en el pensamiento racional, el único acontecimiento del cual jamás podremos tener una experiencia individual... Que sólo puede ser aprehendido bajo la forma de angustia, del presentimiento o del deseo funesto... En el modo del futuro anterior, por lo tanto... Y no obstante, habremos vivido la experiencia de la muerte como una experiencia colectiva, fraterna además, fundiendo nuestro estar-juntos... Como un Mit-sein-zum-Tode..." (p. 104/5)
\end{abstract}

Para o narrador essa experiência da morte não habita a interioridade inefável do indivíduo burguês descrita por Benjamin. Se há uma interface com a busca desesperada da vivência interior do indivíduo problemático burguês na sociedade capitalista, esta repousa novamente sobre sua negação, não sobre a impossibilidade de uma interiorização pessoal dos acontecimentos, mas em sua difícil busca e realização. Esta vivência interior da morte se funda em e funda um "nós", porque significa o despojamento total do eu, de uma existência pautada na pretensa formação (Bildung) individual burguesa. ${ }^{66}$ Como para este sobrevivente

todavía de temer así." In ADORNO, Theodor W.. Dialéctica Negativa - La jerga de la autenticidad. Trad. Alfredo Brotons Muñoz, Madrid: Ediciones Akal, 2005, p. 331-332.

${ }^{66}$ Imre Kertész é um escritor-testemunha do Holocausto que guarda uma concepção semelhante à de Semprún quanto à reivindicação de transformar suas vivências em experiências, a negatividade em positividade: "E, acima de tudo, quero poder decidir acerca da qualidade das minhas vivências: ser livre para não compreendê- 
algo que não é "creíble, no es compartible, apenas comprensible", pode ser dito? Serão justamente a forma deste não dito e o "como" o que tem de ser dito não pode ser dito, enfim, as manifestações de seu ser não dizível que constituirão sua abertura para dizê-lo. Para o narrador, a transmissão de algo intransmissível dá-se a partir e mediante sua intransmissibilidade. O horror, aquilo que nos escapa, fazse visível por sua ação de nos escapar.

O fragmento reitera essa ação de algo que nos escapa ao terminar com a surpresa interrogativa do tenente Rosenfeld acerca do desconhecimento do personagem-narrador sobre $o$ vínculo de Heidegger com o nazismo. $O$ personagem-narrador termina sua exposição ao seu interlocutor fazendo uma alusão ao pensamento do filósofo: "habremos vivido la experiencia de la muerte como uma experiencia colectiva, fraterna además, fundiendo nuestro estarjuntos... Como um Mit-sein-zum-Tode..." (p. 105) A ignorância do personagemnarrador acerca do compromisso do filósofo com o nazismo liga-se à dialética entre conhecimento e ignorância, consciência e inocência, que nesta situação narrativa está condicionada à determinação da noção de passagem, de aproximações e distanciamentos que acarretam perdas.

Assim, o quarto fragmento narra as peripécias do personagem-narrador para a obtenção do livro Sein und Zeit de Heidegger por livrarias, leituras, cursos, atitudes críticas, referências metodológicas, possibilidades hermenêuticas que delineiam uma trajetória particular e, simultaneamente, contextualizada na História, na qual experiência e inocência, conhecimento e ignorância iluminam-se e apagam-se mutuamente. O narrador mostra os caminhos pelos quais suas afinidades e incompatibilidades intelectuais passadas o fizeram percorrer, incorrendo em descobertas, mas também em perdas.

Ao final da narração da aquisição do livro, o narrador faz uma digressão sobre os escritos de Heidegger em que permeia o jogo imagético entre esclarecimento e obscurecimento da consciência na busca de conhecimento. Para

las, livre para usá-las a fim de proferir sobre outros um juízo moral ressentido, ou, ao contrário, para procurar justificá-las - e ser livre também para compreendê-las, para sentir-me chocado com elas, para nesse choque buscar minha libertação, para fazê-las experiências, transformá-las em saber e incluí-las como conteúdo em minha vida futura." In KERTÉSZ, Imre. "O infeliz século xx" in A língua exilada. Trad. Paulo Schiller. São Paulo: Companhia das Letras, 2004, p.31. 
descrever a experiência do personagem-narrador com o pensamento do filósofo, o narrador utiliza expressões como "fascinación", "profusa oscuridad", "fulgurantes descubrimientos", "impresión muy pronto desvanecida, u oscurecida", "opacidad improductiva del movimiento conceptual" (p. 107-108) que oferecem uma imagem de sua linguagem como se suas palavras percorressem ruas e esquinas, caminhos inusitados e labirínticos, sem nunca permitir-nos alcançar uma clareza do conjunto de seus conceitos. Essa face labiríntica da filosofia heideggeriana é criticada pelo narrador mediante a chave da tradução. O narrador indaga-se se uma filosofia que se arroga intraduzível como a de Heidegger pode possuir profundidade e universalidade, ou seja, ter alguma validade.

O próximo fragmento, o quinto, retoma a cena com o tenente, a caminho da casa de campo de Goethe, dando andamento à sua pergunta a respeito da razão do mal-estar do personagem-narrador: “_ ¿Los pájaros?” (p. 109), pergunta o tenente (e traduz o narrador) ao ver a súbita alegria do ex-prisioneiro. O narrador versa sobre a retirada e o retorno dos pássaros ao Ettersberg, que explicam sua emoção: a presença "ruidosa y múltiple" da vida retorna após "años de silencio glacial". Depois de ouvir as explicações, o tenente pergunta-lhe sobre o motivo da fuga dos pássaros e lança a dúvida: “_¿Volverán, ahora? - susurra.” (p. 110) Em seguida, o personagem-narrador retoma na conversa o tema do começo da narrativa sobre Buchenwald. A idéia de iniciá-la por Goethe ou por León Blum para chegar a Goethe surpreende ainda mais o oficial que ignora a relação entre ambos. A narração potencializa a tradução como passagem com duvidosos regressos, relações desconhecidas entre significados e sentidos.

A narrativa ruma ao seu aparente motivo central, a apresentação do personagem Rosenfeld. Mas é importante observar como o verbo "volver" repetese enfeixando uma polissemia que compõe a descrição do personagem:

"Tal vez vaya yo a aprovechar este momento para hablar de Walter Rosenfeld, al que jamás he vuelto a ver, del que jamás he vuelto a tener noticias (...) Volviéndose estadounidense, había elegido la universalidad de la causa demomcrática: la derrota de su país era la condición necesaria para que esa universalidad posible se volviera concreta." ( $p$. 111-112) 
Rosenfeld torna-se norte-americano a fim de restabelecer os princípios universais democráticos. Para tanto, regressa à Alemanha, sua nação de origem, e volta-se contra o nazismo, depois do exílio. O motivo, a origem, a causa também norteiam a apresentação do personagem. A "democracia" consiste na causa da mudança de sua nacionalidade. $O$ encontro do ex-prisioneiro com o personagem deve-se ao compromisso de Rosenfeld com a culpa alemã. Mas o motivo mais decisivo da implicação de Rosenfeld na obra corresponde à trajetória de sua história marcada pela infância, o exílio e o retorno ao país natal. ${ }^{67}$ Não podemos esquecer que, conforme o narrador, seu retorno a Buchenwald, em 1992, consiste no motivo de voltar ao romance, reintroduzindo Rosenfeld no mesmo. A história de vida de Rosenfeld é feita de deslocamentos, transformações e perdas dolorosas. "Judío berlinés" de origem, o exílio nos Estados Unidos e a posterior nacionalização representam a artificialidade e a violência que residem no princípio de identidade nacional fundamentada no nascimento. Na perspectiva do narrador, o retorno de Rosenfeld à Alemanha significa uma atitude ética pela qual ele se responsabiliza pelos crimes de seu país confrontando-o e assumindo uma condição de diferença irredutível, a de ser alemão e judeu. Este percurso de vida do personagem, assim como o de Axel Corti, pode ser comparado à concepção de tradução que permeia a teoria da tradução de Benjamin, ligada à sua filosofia da história. ${ }^{68}$

\footnotetext{
${ }^{67}$ A crítica literária sobre Jorge Semprún costuma mostrar como as experiências pessoais e históricas do escritor transformam-se nos temas de sua obra, gerando ciclos, identificados segundo a experiência predominante no texto, e formas textuais diversas tais como a autobiografia, o romance, o testemunho, as memórias. A crítica, portanto, tende a classificar os temas de sua obra em função das fases de sua vida e a sublinhar uns em detrimento de outros conforme o grau de importância que considere que este assume em uma determinada obra, em um ciclo ou na evolução de sua obra em geral. O exílio, por exemplo, é considerado por Ofélia Ferrán a experiência que explica a relação do autor com o mundo e a literatura. É neste sentido que a autora fala dos tipos de exílios de Jorge Semprún: "Semprún fue, pues, víctima del exílio político después de la guerra civil española, luego víctima de un exílio mucho más radical, al vivir una experiencia como el Holocausto, y, posteriormente, víctima de la incapacidad de diferentes naciones de saber incorporar plenamente a alguien que ha cruzado tantas barreras de tantos tipos en su vida. Son estos diferentes exilios los que se intentan conjurar constantemente en las novelas de Semprún. En ellas, el escritor busca ese único terreno que logra sentir como una patria, el del lenguaje, terreno donde no sólo nos logra comunicar esas experiencias de exilio, sino que lo hace a través de la invención lingüística." In FERRÁN, Ofelia "'El largo viaje' del exilio: Jorge Semprún" in SOLER, Manuel Aznar (ed.) El exilio literario español de 1939. V. 2, Serpa Pinto. 1. Barcelona, Spain: Grup d'Estudis de l'Exili Literari, Departament de Filologia Espanyola, Universitat Autònoma de Barcelona (GEXEL), 1998, p. 109.

${ }^{68}$ Gagnebin nos mostra como no terceiro estágio histórico da tradução, traçado por Goethe, ela se efetua na medida em que renuncia à originalidade da língua nacional de chegada, tornando-se alheia a si mesma, para
} 
Em certo momento da apresentação do personagem, a idéia de causa, origem, ingressa com o significado de intromissão: "Pero, en definitiva, se debe a Heidegger, a la intrusión de Martin Heidegger en nuestra conversación, el que el teniente Rosenfeld me hablara de su infancia berlinesa desde el primer día." ( $p$. 113, o itálico é nosso) Sob a perspectiva do narrador, a intromissão de palavras e nomes possibilita ampliar o conhecimento, a recuperação do passado e a abertura para o novo, fundamental tanto na tradução de textos como na atividade hermenêutica do sujeito em sua relação com a realidade. É "en el transcurso de conversaciones posteriores" que Rosenfeld apresenta-lhe os intelectuais exilados que despertam nele "horizontes desconocidos, curiosidades y apetitos de saber" (p. 114, o itálico é nosso) O personagem-narrador reconhece, entre eles, Broch e Bertolt Brecht cujo poema "Alemanha"69 entrelaça os últimos fragmentos como uma recitação sua e de Rosenfeld e como rememoração do narrador.

Na seqüência, o narrador nos conta quando e onde descobriu a poesia de Brecht. A descoberta enseja o episódio com Julia, em 1943, em Paris, quando se escondiam no seu apartamento do controle da polícia, ao alarme de recolhida. Julia era uma companheira de Resistência, de Viena, que the falou de Brecht e

assim identificar-se com o outro, o original da língua de partida. Gagnebin analisa como a teoria da tradução de Benjamin se sustenta em uma ética da tradução. Segundo a autora, a relação com o outro, o diferente, presente na práxis da tradução requer para Benjamin um afastamento da própria língua e cultura, ou seja, da identidade histórica e cultural do tradutor, a fim de num movimento profundo de perdas e renúncias reencontrar o "eco de uma outra língua, universalmente verdadeira", a original, que se conserva justamente nas e através das transformações sofridas pelas traduções ocorridas no decorrer da história, nas e através das diferentes línguas, portanto. Essa concepção de tradução é a que se presta ao título de nosso capítulo. In GAGNEBIN, Jeanne-Marie. "Origem, Original, Tradução" in História e narração em Walter Benjamin. $2^{\mathrm{a}}$ edição, São Paulo: Perspectiva, 1999.

${ }^{69}$ Os dois versos do poema que o narrador transcreve ou em alemão ou no caso em espanhol são o primeiro e o último versos:

\section{Alemanha}

Ó Alemanha, pálida mãe!

Como apareces manchada

Entre as nações.

Entre os imundos

Te destacas.

Ó Alemanha, pálida mãe!

Como te trataram teus filhos

Que assim apareces entre os povos

Um escárnio e um pavor!

In BRECHT, Bertolt. Poemas 1913-1956. Trad.: Paulo Cesar Souza. 4a edição, São Paulo: Brasiliense, 1990, p. 124-125. 
que compartilhava com ele a paixão pela literatura. Ao amanhecer, quando saía do apartamento, Julia pediu-lhe: “ $N$ No mueras!” O personagem-narrador riu, pois se sentia invulnerável. O breve episódio incide no sentido de descobrir ${ }^{70}$, além da passagem de um idioma a outro nas recitações dos personagens.

No sétimo fragmento, o personagem-narrador e Rosenfeld recitam Brecht, sentados na grama à beira do rio $\mathrm{Ilm}$, diante da casa de Goethe, enquanto esperam que alguém abra a porta. A casa está trancada e nenhum funcionário aparece para recebê-los. O personagem-narrador conta ao tenente o episódio de Julia, quando conheceu Brecht.

Nos dois últimos fragmentos, a narração finaliza a ação da visita à casa de campo de Goethe. A entrada na casa só se realiza após um enfrentamento do tenente com o funcionário que a guardava. O guia é descrito como um guardião zeloso que protege a casa do escritor alemão como se fosse um templo sagrado da cultura germânica, lugar que "intrusos" procuram profanar com sua presença indigna. O velho guia, inconformado com a indiferença de Rosenfeld para com suas reclamações às suas costas, começa a contar-lhes, elevando o tom da voz, a última visita de Hitler. Rosenfeld, farto, tranca-o no armário, isolando a "mirada cargada de odio" e a "voz llena de odio y desesperada" do velho guardião nazista. O trecho representa como a ideologia nazista, ainda muito presente neste momento na Alemanha, exclui as regras de hospitalidade para com o estrangeiro, o outro, encarado como um intruso incômodo, tornando-o invisível e, por conseguinte, indiferente. A história da visita ao seio da cultura germânica revela 0 outro significado contraditório da palavra hospitalidade: hostilidade. A narrativa problematiza e contextualiza, deste modo, a relação entre indiferença e conhecimento, visibilidade e destruição, isolamento e intromissão.

A recorrência da rememoração do poema de Brecht articula-se com os processos históricos sofridos como perdas inexoráveis. O personagem-narrador sente os dois anos transcorridos entre a descoberta de Brecht com Julia e esse momento de recitação como uma eternidade. A certeza incongruente de ter

\footnotetext{
${ }^{70}$ Segundo Gagnebin, descobrir corresponde para Benjamin a um dos modos de apresentação do originário, junto com o reconhecimento. In GAGNEBIN, Jeanne-Marie. Op. cit., p. 15.
} 
atravessado a morte o faz duvidar da possibilidade de regresso a si e ao mundo: “¿Volvería a mí, algún día?” (p. 121) A incerteza de ter voltado dessa "viagem” é revelada a ele justamente quando o tenente o chama para voltar ao campo: "_Es hora de volver - me dice el teniente Rosenfeld" (p. 121) Ato seguido, o personagem-narrador contempla o sol de abril, a casa de campo de Goethe, ouve o "susurro profuso de los pájaros" e conclui: "la vida reiniciada, en suma". No entanto, a alegria sentida por ele em "volver" (posto no texto entre aspas: "estoy contento de 'volver', como acaba de decir Rosenfeld"), junto aos companheiros que "regresan de una larga ausencia mortal", reafirma o caráter duvidoso do regresso à vida "normal".

O sentido de voltar à vida em liberdade fora do campo de concentração é invertido literal e figuradamente. O primeiro passeio fora do campo, um regresso à vida natural e civilizada representadas pelos pássaros e pela casa de Goethe, provoca-lhe desde o início uma alegria perturbadora. O sentimento familiar de regresso à casa ocorre de fato quando o sentido de voltar ao mundo é invertido, quando ele retorna a Buchenwald. O capítulo representa como a experiência do campo de concentração inverteu o sentido do lar, do interior, do mundo familiar e cômodo: o homem que se viu excluído do mundo, que o percebeu em sua invisibilidade imponderável, sente-se o estranho ao retornar a ele, pois este mundo deixou de ser sua casa e, inversamente, o lugar de exclusão passou a ser seu lar. O retorno ao mundo da liberdade, naquele momento, corresponde a um duplo fracasso: ou a porta do mundo está fechada e o guardião da chave não se encontra ou sua entrada é hostilizada pelo guardião como se ele fosse um intruso. A libertação dos prisioneiros dos campos de concentração não acarretava a transformação do mundo que os havia recluído e transformado.

O processo de tradução simboliza essa passagem transformadora, essa viagem iniciática sem volta pelo campo de concentração. As perdas que o exprisioneiro sofre na sua internação em Buchenwald se expressam no sentido que escapa e se perde do tenente Rosenfeld ao emitir a palavra "volver". Um sentido, no entanto, acrescentado pelo receptor, portanto intruso. $O$ capítulo sugere que a passagem pelo universo concentracionário implica, como na tradução de um texto, 
uma transformação ontológica do ser-texto que redunda em perdas e em intromissões de velhos e novos sentidos que não são redutíveis aos estritos significados e precisas referências das palavras da língua e do lugar de partida. A tradução conforme é concebida pelo narrador significa uma viagem sem retorno à origem sob pena de reencontrar outro mundo, outro texto, alheio a si mesmo, sem possibilidades de reconhecimento do original, da identidade primeira. Daí a tradução poder ser entendida como uma metáfora desse processo de autoestranhamento que a experiência do campo impôs ao sobrevivente. Mas, sobretudo, a ação do capítulo diz respeito à inversão do ponto de partida, à inversão da língua de origem que definiria a identidade do indivíduo-texto. Não é mais o mundo em que nasceu o deportado o seu lugar de origem e isso pôde ser reconhecido, com um verdadeiro efeito de anagnoris, ao chegar a ele e percebê-lo como um texto traduzido em uma língua estranha, como um mundo hostil refletido em outra língua, no qual "volver" possui agora um sentido contrário, significa que este mundo ao qual deveria retornar como seu não é mais o ponto de partida e sim o de passagem, ao passo que Buchenwald se tornou sua origem e não mais o "local de passagem".

O sentido do riso do personagem-narrador diante do pedido de Julia, "iNo mueras!", dista e difere, sem possibilidade de coincidir, do sentido de seu outro riso em face do retorno dos pássaros ou ainda do sorriso que reconhece a eternidade transcorrida entre os dois risos. A mesma palavra "risa" designa contextos e identidades tão diversos a ponto de não haver equivalência de significado. Palavras opostas como "risa" e "espanto", presentes no poema de Brecht, referem-se, ao contrário, a uma mesma circunstância: o riso de espanto ou o espanto do riso em face do horror cometido pelo Estado alemão. A palavra "volver" implica a afirmação do ato a que se refere e, em outro sentido, a negação da vida. A narrativa constrói um jogo de palavras e contextos cujos limites e condições a que a linguagem está submetida em seu processo semântico demonstram a insuficiência dos signos para traduzir a realidade do universo concentracionário. O sentido da catástrofe da Shoah traduz-se, neste texto, no sentido que sobra, que não é captado pelo interlocutor Rosenfeld ou por nós 
leitores, integralmente, ao se emitir e traduzir a palavra "volver". Assim, a catástrofe do campo é objetivada neste capítulo através de uma situação narrativa cuja ação representa a impossibilidade de que ela seja traduzida integralmente.

Embora a identificação entre o tenente Rosenfeld e o personagem-narrador tenha propiciado um diálogo que contempla todas as formas discursivas apresentadas neste estudo, a incompletude de sentido no ato comunicativo e tradutório da palavra "volver" aparece como metáfora da ausência de liberdade de narrar, descrever, expressar e refletir sobre o Mal radical do campo de concentração.

À primeira vista, podemos imaginar que a apresentação, a caracterização e a construção do personagem Rosenfeld funcionariam como princípio organizador do capítulo. Rosenfeld é compreendido como aquele que vai e volta, como aquele que após o exílio retorna ao berço de sua cultura, a Alemanha, em busca de recuperar a própria identidade pautada em valores universais. A narrativa problematiza o sobrevivente como aquele que vai, mas para o qual não há volta, pois ele sofre uma transformação com a catástrofe, de certa maneira tornando-se prisioneiro dela. Assim, o elemento estrutural espacial entra em tensão com o das personagens, pois, se a construção de Rosenfeld baseia-se no seu itinerário de vida, o trajeto do sobrevivente manifesta-se indescritível, intraduzível e aporético, ou seja, prenhe de uma impossibilidade objetivada em sua forma.

\subsection{A transposição do Mal: a variação do jazz sob a solidão da neve}

O princípio organizador do quinto capítulo, "La trompeta de Louis Armstrong", é a música, mais especificamente o jazz. O sentido do capítulo reside na busca de adequação do sobrevivente à nova vida e na busca de transposição de sua experiência do campo ao mundo exterior. O jazz se lhe apresenta como um meio para a realização dessa adequação e transposição. A estrutura do capítulo, contudo, representa como não há possibilidade de adequação do sobrevivente e transposição completa da experiência do campo ao mundo de fora 
através da transposição incompleta do texto à matriz do jazz. Os episódios centrais do capítulo são a festa em Eisenach e a partida de um comboio de sobreviventes a Paris. Num hotel de Eisenach, durante uma noite de festa, no final de abril de 1945, os prisioneiros de guerra e os deportados da região, enquanto aguardam os próximos trâmites de sua repatriação, divertem-se ao som do jazz de Armstrong, embriagando-se, conversando e dançando com as voluntárias de uma Missão do exército francês. Ao final da festa, pela manhã, o personagem-narrador é chamado pelos companheiros para integrar um grupo que parte num comboio a Paris. Enquanto esperam a partida do caminhão, os sobreviventes conversam a respeito de "como" contar o que viveram em Buchenwald.

A ação representada refere-se à dialética entre poder e não poder testemunhar como forma de realização da liberdade que o regresso à vida pressupõe. Por um lado, a festa dos sobreviventes em processo de repatriação em Eisenach promove o diálogo com pessoas de fora que demonstram uma indisposição e incapacidade para ouvir e compreender a experiência atroz do campo de concentração. Por outro lado, a conversa com os companheiros da viagem a Paris problematiza o testemunho, partindo do pressuposto de que jamais haverá uma compreensão completa da "verdade" da experiência. O testemunho dessa experiência aparece aqui condicionado à concepção e à capacidade artística do sobrevivente de representá-lo para que possa realizar-se como experiência comunicável, mas também dependente da atitude e da reação do mundo exterior como receptor. As palavras "regresso" e "repatriação" sofrem uma relativização que se enraíza no modo como o mundo recebe os sobreviventes dos campos de concentração. A nova ordem política mundial não possibilita, por exemplo, a repatriação dos ex-presos políticos espanhóis. O desinteresse do mundo por todo o horror cometido e sofrido significa uma forma de reprodução, de continuação daquele pesadelo para os sobreviventes. ${ }^{71} \mathrm{~A}$ polissemia será desenvolvida ao longo do capítulo com situações e expressões que exprimem a

\footnotetext{
${ }^{71}$ Isto é traduzido por Primo Levi em É isto um homem? quando seu narrador conta o pesadelo, recorrente entre os prisioneiros, de voltar a casa, começar a contar o que viveu e ser abandonado pelos seus que lhe voltam as costas. In LEVI, Primo. "As nossas noites" in É isto um homem? Trad. Luigi Del Re. Rio de Janeiro: Rocco, 1988, p. 60.
} 
idéia de apoderar-se de algo, ter as faculdades de outro, substituí-lo, multiplicando o sentido da dificuldade de transposição e superação da experiência.

Assim, o estranhamento com os de fora do campo, sempre relativo e contraditório, assim como a identificação com os de dentro, tampouco plena senão conflituosa, reproduzem a síntese dialética do movimento final desta primeira parte do romance. A introdução e o final do capítulo deixam patente esta lógica: a felicidade inicial do personagem-narrador ligada ao som do jazz de Armstrong termina na infelicidade da sensação de não ter voltado à vida, associada à lembrança da neve do campo de Buchenwald. Não só felicidade e infelicidade se antagonizam e se identificam, mas também som e imagem, audição e visão, jazz e neve. A voz solitária do sax de Armstrong, improvisada a cada percurso desta espiral vertiginosa, contrapõe-se e contraditoriamente é análoga à imagem solitária desta lembrança repetitiva, eterna, da neve. Outros termos dialéticos entrelaçam-se nesta composição, tais como conhecimento (da alma) e ignorância (do corpo), prazer e sofrimento, pergunta e resposta, lucidez e idiotice, ver e nãover, crível e incrível, imaginável e inimaginável, transmissível e intransmissível, etc. O capítulo num todo sintetiza o passado recente da libertação e antecipa a evolução da história. A aparência de circularidade, derivada da repetição das imagens obsessivas e da sensação de ruína definitiva do sobrevivente, está implicada na profunda transformação sofrida no campo que a requer como móvel necessário de uma nova transformação, a de superar de imediato essa ruína para poder elaborar a experiência da sobrevivência. Neste sentido, o capítulo representa a relação modificada de estranhamento e de identificação com os de fora do campo de concentração: a dificuldade de ver e de ouvir a experiência daqueles que não a viveram reapresenta-se expandida e aprofundada na própria dificuldade de superá-la e transpô-la daquele que a viveu, o sobrevivente.

Em "La trompeta de Louis Armstrong", o discurso narrativo prevalece de modo evidente sobre os demais. Os tempos pretéritos da narrativa despontam e com eles tomamos certa distância da matéria. O discurso lírico submete-se às situações de conquista ou de encantamento do personagem-narrador com as mulheres, distante de sua recorrente função reflexiva e libertadora. A descrição 
pincela principalmente a indisposição e incapacidade de diálogo do ouvinte, registradas em seus olhares, sua cegueira, vozes e tipos de silêncio. A digressão dilui-se na destreza de contar explicando do narrador. Cabe sublinhar que os diálogos da festa em Eisenach não desenvolvem a reflexão, a narração nem a descrição; ao passo que no diálogo com os companheiros do comboio a Paris, a reflexão é a forma discursiva mais desenvolvida em detrimento das demais. A narrativa patenteia assim o prescindível da narração e da descrição entre os companheiros, enquanto que a reflexão e a evocação lírica desempenham um papel importante na elaboração de sua experiência e na sua sobrevivência. A predominância do discurso da narração deve-se à transposição da matriz do jazz ao fio narrativo do capítulo, através do motivo do som inebriante do trompete de Louis Armstrong com suas sinuosidades.

Assim, na primeira cena do capítulo, o personagem-narrador, dançando com Martine D., uma missionária francesa de guerra, reconhece a canção de Armstrong que os embala: "On the sunny side of the street": iqué felicidad!" ( $p$. 122)

A frase musical que abre o primeiro fragmento e a exclamação do personagem-narrador anunciam o conflito que ele carrega neste momento: a volta do desejo e dos prazeres da vida em contradição com os sofrimentos gravados na memória, suscetíveis a atualizarem-se por qualquer descuido da vontade ou qualquer associação involuntária de pensamento. A narrativa problematiza a luta entre a vida e a morte, transformada depois da experiência traumática de Buchenwald, através de outra relação, tradicional na filosofia moderna, aquela entre a liberdade e a necessidade. O narrador destaca seu estado de embriaguez, o encantamento produzido pela música de Armstrong, o desejo sexual crescente enquanto dançava com Martine $D$. e a atração que seu olhar exercia sobre a jovem. Um olhar que a perturba por expressar "sorpresa", "curiosidad", "naturalidad" e "franqueza" e que sem artifícios, com "la voz de cobre de Louis Armstrong", "abría avenidas de deseo infinito", fazia-a estremecer

"como si tuviera de repente un deseo pánico del insólito pasado de donde yo procedía, del desierto que a mi pesar se anunciaba en mis ojos. 
O pavor e o horror que seu olhar antes causava, agora, quinze dias depois da libertação transforma-se com as mulheres em "deseo pánico". A alusão a Pã deus grego, metade homem, metade bode, que assustava os homens e os animais com o som de sua flauta - simboliza o poder mítico atribuído à música proveniente do instrumento de sopro, fálico inclusive, manejado por Armstrong.

O narrador compara implicitamente o poder perverso, enganador "de aquella mirada" sobre as mulheres com o sentido da palavra regresso - "curiosa palabra, hipócrita, equívoca cuando menos" (p. 123) - e diz ter usado este poder eficaz sem escrúpulos. $O$ jogo de sedução entre o personagem-narrador e as mulheres é comparado com uma caçada: seu olhar faz as vezes de uma armadilha para agarrar "la alondra" ludibriada que acredita "contemplar su propia imagen embellecida por el interés del otro." (p. 124). O olhar que espelhava o horror no primeiro capítulo, agora menos próximo ao horror, ao invés de afastar o outro, atrai-o, permitindo que o personagem-narrador tenha acesso aos prazeres sexuais: "ya no era descifrable a primera vista, como lo había sido para los tres oficiales con uniforme británico, quince días antes." (p. 123) Mas a perspicácia desse olhar é questionada pelo narrador que se pergunta como sua agudeza e poder de penetração puderam atuar se "no había nada que ver, nada que adivinar (...) tan sólo la superfície sin azogue de un pasado abominable". ${ }^{72} \mathrm{~A}$ impossibilidade de ver retorna sob a forma de uma força de atração incompreensível, narcisista, utilizada como recurso de satisfação do desejo e de sobrevivência, cujo horror, porém, continua agindo de forma nefasta sobre o sobrevivente ao reavivar em sua memória as dores da deportação: "la muerte que quería olvidar."

O silêncio dessa fase instala-se como um silêncio de sobrevivente: "No con un silencio afectado, ni culpable, ni temeroso tampoco (...) Un silencio rumoroso

\footnotetext{
${ }^{72} \mathrm{O}$ sentido de transformação dialética, apesar da dispersão e da repetição dos temas deste romance, pode ser observado não só na sua estrutura, mas também no trabalho da linguagem. A expressão "la persistencia eficaz de aquella mirada", situada no primeiro parágrafo do segundo fragmento, condensa-se de certo modo em "procedimiento perspicaz", encontrada no terceiro parágrafo da página seguinte. Perspicaz reúne "persistencia” e "eficaz” através de uma operação sintética.
} 
de apetito de vivir" (p. 123). Mas sua mudez sobre Buchenwald em função do velho desejo de sobreviver é sobrepujada pela voz do olhar: "Pero, al parecer, no conseguía hacer que callara mi mirada" (p. 124). Por um lado, a algazarra da vida deslumbra o personagem-narrador, ofusca sua vista emudecendo-o; por outro, o olhar expressa o que o silêncio omite.

A narrativa envereda nas vivências passadas do corpo do sobrevivente, problematizando a dialética entre prazer e dor sob o signo da liberdade e da necessidade, para sondar o Mal em Buchenwald. Dançando com Martine D. ao som de Armstrong, o narrador enfoca o assombro que lhe causa a rápida recuperação do princípio de prazer em seu corpo. O desejo nele cresce, impõe-se e ocupa o lugar de uma ausência, a de um "cuerpo enflaquecido, algo fantasmal", que volta a possuir um poder curativo sobre a alma: "Era un bálsamo para el alma esta alegría carnal. Mi cuerpo me llenaba de asombro, tengo que reconocerlo." ( $p$. 125).

O narrador discorre sobre sua relação com seu corpo antes, durante e depois de Buchenwald. Nesta digressão, o campo aparece como experiência que transformara a consciência que tinha de seu corpo. Três fases dialéticas distinguem-se nesta transformação: a impetuosa juventude, a experiência da tortura e da internação em Buchenwald e a atual recuperação das forças físicas e do desejo. Na primeira, corpo e consciência (desejo e vontade) formavam um todo inseparável como se não houvesse relação. A máquina corpo obedecia aos comandos de sua senhora consciência, graças à ignorância da existência de um pelo outro, o que manifestava a falsa unidade entre ambos. A narrativa expõe a hybris juvenil, a ignorância inocente e presunçosa dos tempos de juventude em que a unidade entre corpo e consciência se apresentava como uma falsa relação de autonomia.

A consciência do personagem-narrador das necessidades e da liberdade de seu corpo ocorre através da "agonía del dolor" da tortura. Capturado e torturado pela Gestapo, ele conhece a independência do corpo em face da vontade consciente mediante a negação de seu ser moral: "Mi cuerpo se afirmaba a través de una insurrección visceral que pretendía negarme en tanto que ser moral." ( $p$. 
126) A tortura é tratada pelo narrador sob a forma de uma luta interna de sua vontade consciente contra as exigências das dores físicas infligidas pelos torturadores da Gestapo. Em seu discurso, seu corpo figura como um mediador insubmisso, infiel e indigno entre a vontade do algoz e a vontade da vítima, que se alienara da última e se aliara à primeira. A caracterização moral do corpo físico converge com o sentido dialético plasmado na narrativa. Para que ocorresse a vitória do seu corpo moral sobre seu corpo físico, o narrador afirma que fora preciso ceder à sublevação do último, permitir que ele se separasse de si e se unisse ao aliado, abandoná-lo à dor e à humilhação. A maneira de dominá-lo, portanto, consistia na descoberta e aquiescência de sua verdadeira autonomia com relação ao seu ser moral. Na medida em que se afastava de seu corpo físico, a vítima torturada sentia-se acercar-se a si mesma.

Em Buchenwald, a experiência do corpo é a da carência, do esgotamento das forças, da obsessão da fome e falta de sono. Vivências que coincidiam com a consciência do antagonismo entre corpo físico e vontade moral. Mais uma vez vencer as exigências do corpo implicava desprezá-lo, tratá-lo com dureza. Do ponto de vista do narrador, a liberdade da vontade realiza-se mediante a compreensão, o domínio e a superação das necessidades do corpo. Sob a perspectiva deste sobrevivente testemunha escritor, o homem eleva-se em sua humanidade moral quando suporta o rebaixamento de sua humanidade instintiva.

O presente fictício da "trompeta de Armstrong" concerne à fase da reabilitação das forças vitais de seu corpo. O narrador descreve um corpo que ao reapropriar-se de suas forças, ao elevar-se em sua natureza instintiva, amoral, possui ao mesmo tempo vontade e majestade, tem o poder de esquecer o que a consciência mesmo desejando tem dificuldade em negar. Nesta fase, é a vitalidade instintiva que se eleva e supera a precariedade do espírito.

No desenvolvimento da cena da festa, surge um oficial francês, presença "inoportuna" que substitui o personagem-narrador na conquista de Martine D.: “¡Buenas noches, amigo! - ha dicho el oficial cogiendo a Martine del brazo y atrayéndola hacia sí. Tenía cara de dueño." (p. 133) O presente verbal adapta-se à ausência de distanciamento crítico do mundo. A idéia de ocupar, substituir, 
assume o sentido de apoderar-se, tomar posse. A ação da força física revoga a da força de atração. O soldado francês é descrito como "un individuo alto y fornido" cuja presença corpulenta limita a liberdade do personagem-narrador e de Martine. O oficial, observando a aparência do sobrevivente, pergunta-lhe se vinha do campo e comenta de modo fático: “¿_Qué, ha sido duro, eh?” O personagemnarrador responde ironicamente que tinha sido umas férias num balneário. $O$ oficial francês, por sua vez, encolhe de ombros e vai embora, levando Martine D.. O diálogo curto entre o personagem-narrador e o oficial enfatiza a imbecilidade do último, farto em força física e parco em conhecimento. A narrativa não retrata uma ignorância inocente, mas sim aquela resultante daquilo que se deveria ou poderia saber, ligada à liberdade e à necessidade do indivíduo e que, contraditoriamente, tem o poder de obstruí-las no outro ao restringir o diálogo. A infelicidade sentida pelo personagem-narrador após o desinteresse do soldado francês por sua experiência é narrada por um discurso que interroga a razão da própria frustração do sobrevivente. O narrador pergunta-se se sua infelicidade se deveu ao despeito de ter perdido Martine D. ou porque estava embriagado. Tais especulações 0 levam a questionar o alcance da pergunta do oficial:

\footnotetext{
"Hay que decir que se trataba de una pregunta imbécil. Absurda en su forma, por lo menos. '¿Qué, ha sido duro, eh?' era una pregunta que no desembocaba en nada, que incluso cerraba cualquier espacio posible de cuestionamiento, a través de una respuesta inevitable, afirmativa, pero que no llevaba a nada. Sí, había sido duro: ¿y qué?" (p. 135)
}

O diálogo que possibilitaria uma reflexão sobre o universo do campo é concebido pelo narrador em sua modalidade de pergunta e resposta abertas que supõem o questionamento. Ao mesmo tempo, as "preguntas mal planteadas" que o narrador afirma ter recebido "cada vez que había tenido alguna relación con gente de fuera" poderiam ser resultado de não conhecer as respostas adequadas: "Pero para plantear las preguntas adecuadas tal vez hiciera falta conocer ya las respuestas." (p. 135) Ou seja, se por um lado o diálogo supõe perguntas abertas, que possam ao menos fazer uma ponte com a realidade que se quer conhecer, por outro lado, a realização desta ponte supõe um conhecimento prévio desta 
realidade. Em outras palavras, a ignorância contraditoriamente requer e rejeita o conhecimento.

Após esse desfecho da cena com Martine, o narrador evoca o episódio da visita das garotas da Mission France a Buchenwald em que havia visto por primeira vez Martine D.. A personagem Martine parece cumprir a função associativa dessa evocação, quando de fato o episódio oferece a "devida" resposta ao tipo de ignorância presente na pergunta "indevida" formulada pelo oficial francês do fragmento anterior. As missionárias surgem "inoportunamente" para visitar o campo no mesmo dia em que o personagem-narrador entrega os livros a Anton. A descrição de seu comportamento e da expectativa que as trazia ali é irônica: "risas: menuda pajarera (...) Querían visitar el campo, les habían dicho que era apasionante. Me rogaron que las acompañara." (p. 135-136) O exprisioneiro nota a presença de Martine. O flerte entre ambos, contudo, é cortado pelo comentário de outra garota, sentido pelo sobrevivente como uma brutal estupidez: “_ ¡Pero si no parece estar nada mal! (...) _ ¿Y eso, es la cocina?” ( $p$. 136)

Entre a exclamação e a frase interrogativa, interpõe-se uma descrição das coisas do campo de Buchenwald moldada pelo ponto de vista superficial da garota. Segundo o narrador, a pergunta destinava-se à identificação da chaminé do crematório. A disposição e o modelo das frases são similares aos do breve diálogo com o oficial francês corpulento, com a inversão de que naquele o comentário segue à pergunta: "_ ¿Vienes del campo? _ Ya lo ve (...) _ ¿Qué, ha sido duro, eh? _ ¡Qué va - respondí, _ este campo era un balneario!" (p. 134) A vestimenta do personagem-narrador observada pelo oficial francês equivale aos edifícios do campo observados pela garota da Mission France. O termo "balneário" é reposto, em certo sentido, pela idéia de "visita turística" das garotas a Buchenwald.

O narrador descreve os sentimentos que o invadiram naquele momento ao ouvir a pergunta da missionária. Segundo ele, teve o desejo de estar morto para não ouvir tamanha insensatez, para não sentir uma irritação e uma infelicidade tão próximas das sentidas por ocasião do comentário do oficial francês. Tal desejo 
desembocava na auto-aversão por estar vivo e ser capaz de ouvi-la. O fato de o mundo exterior aceitar aquele horror como algo familiar e atraente faz com que o sobrevivente sinta repulsa a si como se fosse uma resposta substitutiva à falta de aversão do outro pelo horror do campo.

O personagem-narrador responde à estreiteza de visão da missionária com o ato lacônico de fazê-las ver. Mostra-Ihes o edifício do crematório, tomado por elas como cozinha. Mostra-lhes o porão onde ficavam os instrumentos de tortura e os fornos. Leva-as ao pátio onde se amontoavam os cadáveres. O narrador insiste no uso do verbo "enseñar", que ambiguamente em espanhol significa ensinar e mostrar: "¿Enseñar? Tal vez la única posibilidad de hacer comprender fuera, efectivamente, hacer ver." (p. 137) O sobrevivente enquanto thes mostra as instalações do crematório, apenas vai nomeando o que indica. O silêncio das missionárias vai se tornando, às suas costas, cada vez mais pesado. Sem a explanação verbal, o fazer ver responde à incapacidade de diálogo do interlocutor, condição de sua visão obtusa. Nesta situação, o silêncio do mundo exterior está intimamente ligado à sua recusa a ver, barreira que impede o sobrevivente de transpor a condição de estranho no retorno à sociedade. Diante desta barreira, ele mostra, indica e nomeia o visto. $\mathrm{O}$ ato de fazer ver do personagem-narrador configura um realismo seco, uma relação enxuta dos objetos apontados, um recuo diante da narração e da descrição detalhada ou emotiva dos acontecimentos e das práticas a que serviam tais objetos. ${ }^{73}$

Diante do amontoado de cadáveres de mais de três metros de altura, o silêncio do personagem-narrador é total. Nenhuma palavra ocupa o lugar da imaginação das observadoras. A proposição do "fazer ver" deste episódio não implica substituir o que não deve ser explicado naquela situação. Ao contrário, o que não é dito faz ver mais longe do que a vista alcança. Fazer ver aqui significa silenciar sobre o visto, cobri-lo com um manto de silêncio, ampliando-o. A situação nos sugere que a palavra deve recuar diante da (e)vidência do horror para que o

\footnotetext{
${ }^{73}$ O realismo do testemunho literário de Semprún difere do realismo do século XIX. Ao invés da descrição objetiva, distanciada, pormenorizada do narrador onisciente do realismo decimonônico, temos um realismo nominativo, rico em substantivação, aparentemente objetivo, mas profundamente indignado e colado à situação.
} 
conhecimento, operação para o narrador imaginativa, sobrepuje os limites dos sentidos e da ignorância. O que não é visto, mas imaginado a partir do visto, fala no lugar do que não é dito. Essa é a resposta à situação anterior.

Mas a ausência de diálogo como resposta à ausência de visão conforma a situação daquele momento em que o mundo ainda podia ver de perto os vestígios do horror dos campos, mesmo ignorando-os ou não desejando conhecê-los. Para a testemunha, calar a respeito quando não se pode ver não faz imaginar, mas sim expõe ao fracasso qualquer perspectiva imaginativa de conhecer o não visto in Ioco. Na perspectiva desta testemunha, a distância temporal referente ao horror do campo de concentração cria um vazio de memória, um risco de esquecimento, que só pode ser preenchido com a mediação da rememoração reflexiva e crítica. A elaboração lingüística da memória da experiência é necessária na medida em que a imediatez das imagens reais não é mais possível ou que outras imagens atuais as sucedem e as imitam em atrocidades semelhantes. ${ }^{74}$

\footnotetext{
${ }^{74}$ A propósito do sexagésimo aniversário da libertação de Buchenwald, em 2005, em Weimar, Jorge Semprún pronuncia um discurso cuja lucidez incide como um golpe irônico na mistificação da noção de "testemunha integral" enquanto testemunha ideal e impugnação da "verdade" relatada e representada pelas testemunhas parciais e reais. Semprún começa o seu discurso lembrando à platéia que esta seria a última comemoração assistida pelos sobreviventes: "Dentro de diez años, em 2015 (...), ya no quedaremos testigos de la experiencia de los Lager nazis. Ya no habrá memoria directa, testimonial memoria vital: se habrá terminado la vivencia (Erlebnis) de aquella muerte. Ya nadie podrá decir: "Sí, así fue, yo estuve...". Ya nadie podrá poner al pie de alguna imagen de la memoria lo que Goya puso al pie de uno de los grabados de Los Desastres de la Guerra: "Yo lo vi...". Ya nadie tendrá en su memoria sensitiva, impregnándola, acaso soliviantándola, el olor de los hornos crematorios, que es, sin duda, lo más específico, lo más singular del recuerdo del Exterminio." E a certa altura acrescenta: "Dentro de diez anõs, (...) al haberse agotado nuestra memoria de supervivientes, porque ya no habrá supervivientes, para que la transmisión de aquella experiencia sea posible, más allá del necesario pero insuficiente trabajo de historiadores y sociólogos, sólo quedarán novelistas. Sólo los escritores, si se deciden libremente a apropiarse de aquella memoria, a imaginar lo inimaginable, a hacer literariamente verosímil la increíble verdad histórica, sólo los escritores podrán resucitar la memoria viva y vital, la vivencia de los que habremos muerto. Lo cual, por otra parte, no tiene por qué sorprendernos ni inquietarnos: siempre ha sido así, siempre será así. Siempre desaparecen los testigos, la literatura testimonial. La única duda, la única pregunta para la cual todavía no tenemos respuesta es ésta: ¿habrá literatura del Exterminio, más allá de la obra testimonial, memorial?" Em seguida, Semprún comenta que "la memoria judía de los campos va a ser la más duradera, [pues] ha habido niños judíos deportados, por millares o decenas de millares, (...), en cambio, no ha habido niños de la resistencia deportados." - o que, para o sobrevivente, significa que "una gran responsabilidad recae sobre la memoria judía (...) Porque será depositaria de alguna manera de todas las experiencias del Exterminio: de la experiencia judía (...) la de los gitanos exterminados como los judíos, por ser como eran; la de los adversarios políticos del hitlerismo. Alemanes comunistas, socialdemócratas y cristianos, en primer lugar; la de los resistentes de todas las guerrillas antifascistas de Europa." Ao final, Semprún reconhece "la singularidad terrorífica del genocidio del pueblo judío, en el marco da la política genérica del nazismo contra todas las oposiciones y todas las resistencias" e procura incluir nesta luta contra os totalitarismos em Europa "la experiencia del gulag. Esperemos que junto a los libros de Primo Levi, Imre Kértesz o David Rousset, hayamos colocado los Relatos de Kolyma de Varlam Chalamov. Ello querrá decir no sólo que habremos dejado de ser hemipléjicos, sino también que Rusia habrá avanzado decisivamente en el
} 
Em frente ao amontoado de cadáveres, diante de um vazio intransponível dentro do qual se situavam os "muertos horribles y fraternales", o personagemnarrador imagina o que lhes faria falta e o que não lhes fazia falta naquele momento para restituir-Ihes a dignidade perdida. Trata-se de um olhar solidário à condição indigna da morte de seus companheiros. A morte ainda presente entre os doentes do Campinho, os cadáveres dos companheiros amontoados no pátio interior, o ritmo alegre destoante do gopak russo ao longe e ao redor deste oco de horror o personagem-narrador, atrás do qual se situam os olhares curiosos das mulheres da Mission France. É nesse cenário que a missão do sobrevivente é revelada a ele: preso neste anel de horror, o sobrevivente, futura testemunha, sente-se portador de uma "verdade" credenciada pela vivência compartilhada da morte do companheiro que habita o vazio central do anel. É na percepção da contradição entre seu olhar puro e fraterno e o olhar curioso e estrangeiro do mundo exterior, que reside para esta testemunha a sustentação de uma "verdade" transmissível. É por refletir no olhar e dar eco a este vazio de palavras do centro do anel que a figura deste sobrevivente se outorga o papel de testemunha credenciada a falar do que "apenas se nomeia". A imagem da "ruidosa pajarera" à qual sobrevêm o silêncio e a partida das figuras femininas da Mission France remete-nos de modo contraditório e irônico àquela do silêncio e da fuga dos pássaros. Para o personagem-narrador, os mortos, naquele momento de indigna exposição, não precisavam ser explicados de maneira alguma, mas seria necessário ter vivido a sua morte e ter sobrevivido, ou ter "ressuscitado" a ela para saber do que não necessitavam. Esse é um conhecimento negativo, interior ao anel e não acessível inteiramente ao mundo. Um conhecimento que se projeta no olhar puro e fraternal que pousa sobre o vazio horrivel dos companheiros mortos, ao qual temos acesso na representação do narrador apenas pela explicação do indescritível e não pela descrição do inexplicável.

Ao amanhecer, no fim da festa, Yves Darriet, companheiro de Buchenwald que inscreve o personagem-narrador nos comboios da missão de repatriação a

camino de la democratización". In SEMPRÚN, Jorge. "Sesenta aniversario de la liberación" in Pensar en Europa. Barcelona: Tusquets, 2006, p. 319-322. 
Paris, espera sua chegada, recebida como "oportuna". Os companheiros discutiam sobre como transmitir a experiência do campo. O modo de narrar a conversa informa-nos sobre as possibilidades de transmissão dessa experiência tanto quanto seu conteúdo. As diversas opiniões e concepções de testemunho abordadas na conversação subordinam-se à forma como se recorta e ilumina a voz dessa testemunha intelectual para construir sua concepção de testemunho literário que estrutura o romance.

A conversação entre os ex-internos é registrada em estilo direto, comentada pelo narrador que assume a perspectiva do personagem-narrador em situação. $O$ estilo direto combina-se e contrapõe-se ao indireto que encaixa apresentações e histórias ou ainda penetra na própria fala dos interlocutores. Variadas formas de mediações vão adensando o tema no decorrer da conversa. A chegada "oportuna" do personagem-narrador à reunião, por exemplo, contrapõe-se à chegada "inoportuna" das missionárias francesas do fragmento anterior. A explicação que Yves dá para a chegada "oportuna" aparece em estilo indireto: "Estábamos preguntándonos como habrá que contarlo para que se nos comprenda" (p. 139) -. A pergunta indireta de Yves opõe-se diretamente às perguntas inadequadas do oficial francês e da garota da Mission France: "Asiento con la cabeza, es una buena pregunta: una de las buenas preguntas" (p. 140) O narrador nos adverte da impossibilidade de transcrever corretamente a conversação. Não se trata de mostrar de maneira objetiva e transparente as respostas dadas à pergunta problema. A conversação contempla um movimento espiralado no qual o problema inicial de como contar para ser compreendido ganha complexidade através da contraposição das falas que oferecem, por sua vez, uma imagem de ascensão da confusão à clareza e outra oposta da efusão de vozes ao silêncio ensimesmado de cada sobrevivente. O modo de representar a conversação coloca a voz do personagem-narrador em primeiro plano, iluminando-a como aquela que ora se eleva da confusão ora a suscita, respondendo às perguntas e comentários indignados dos interlocutores. Somente a voz do professor da Universidade de Estrasburgo, que dá volume ao argumento do personagem-narrador sobre o modo adequado de contar, atinge uma ressonância parecida. Mesmo assim, a narrativa 
encaixa na fala do professor o episódio da palestra sobre Rimbaud dada pelo personagem-narrador numa sessão de entretenimento dos prisioneiros organizada pelo aparelho clandestino de Buchenwald, o que recoloca este interlocutor no papel de ouvinte. São as palavras do personagem-narrador que finalizam a conversação com a alusão a Dostoievski, o mestre não só da "exploración del alma humana", mas também da polifonia desejada por este narrador.

$\mathrm{Na}$ ordem do discurso, a conversa apresenta primeiramente o problema de como contar para ser compreendido, segundo Yves. Um interlocutor contrapõe a tal problema o de ter vontade de ouvir para compreender: “¿Estarán dispuestos a escuchar nuestras historias, incluso si las contamos bien?" (p. 140) Outro interlocutor apresenta uma nova oposição que retoma o problema de como contar ao negar a ressalva de "contar bem" e afirmar a necessidade de um realismo puro, sem artifício, que relate as coisas como elas são: "iHay que decir las cosas como son, sin artificios!" (p. 140) A esta nova oposição o personagem-narrador repõe, através de um jogo de palavras que sintetiza o que foi afirmado e negado, opinando que contar bem significa: "de manera que se sea escuchado. No lo conseguiremos sin algo de artificio. ¡El artificio suficiente para que se vuelva arte!" (p. 140) Logo após a confusão gerada, o personagem-narrador discorre sobre "as coisas como elas são" do campo de concentração, sobre a natureza inverossímil e inimaginável da "verdade" que poderá ser contada, dependendo da vontade e do poder de contá-la da testemunha. Outro interlocutor ironiza a formulação do problema feita pelo personagem-narrador, reafirmando a situação do ouvinte que mesmo disposto tenha dificuldade em acreditar e do sobrevivente que não pode ou não quer contá-la: "Tan poco creíble que yo mismo voy a dejar de creerlo jtan pronto como pueda!" (p. 140) Em seguida, a fala do personagem-narrador procura concluir seu raciocínio apresentando a necessidade da imaginação artística, da elaboração da realidade para transformar o inimaginável em verossímil, o irreal em real. A lógica e o jogo de palavras contidos em sua formulação são notoriamente influenciados pelo pensamento dialético: “¿Cómo contar una historia poco creíble, como suscitar la imaginación de lo inimaginable si no es elaborando, trabajando la realidad, poniéndola en perspectiva? ¡Pues con un poco de artificio!” (p. 141) 
Trata-se de uma acepção dialética da tensão no testemunho entre necessidade e liberdade, entre realidade e ficção: necessidade de ser fiel à realidade vivida e, portanto, escassa liberdade de invenção em termos de conteúdo que, por sua vez, se mostra inverossímil. Na perspectiva do narrador, a necessidade estética está implicada na resistência da matéria a ela, no seu caráter inverossímil. A necessidade de aproximar-se da matéria literariamente, de elaborá-la segundo as leis de uma "verdade" alheia a ela, surge devido ao distanciamento que a literatura tem da realidade. É justamente do estreitamento da liberdade de lidar com a matéria, com os fatos reais, que deriva a necessidade de retirá-los de sua obscuridade, de seu fechamento à imaginação e à compreensão. Em outras palavras, a ficção e a criação estéticas enquanto reino da liberdade fazem-se necessárias para representar o Holocausto porque esta realidade mostra-se avessa à liberdade da imaginação e da consciência enquanto reino da necessidade. Para o narrador, é na relação contraditória do homem com o real, movida pela carência e pelos limites paradoxais, mas também condicionada pela necessidade de liberdade e de atribuir sentido ao real, que se dão a criação estética e o testemunho literário.

O problema ganha uma nova dimensão com a intervenção do professor de Estrasburgo, cuja capacidade de "formular con tanta claridad los problemas" sossega os interlocutores. O novo problema é apresentado também por meio de uma pergunta aberta: "de qué tipo de comprensión se trata?" (p. 141) A "verdade" do testemunho subdivide-se então em duas "verdades" que não se anulam, mas se contradizem. Uma diz respeito ao conhecimento objetivo produzido pelas diversas áreas científicas, apoiado em documentos, testemunhos, em métodos analíticos objetivos que buscam fazer-nos ver a realidade tal como ela é de maneira a dar conta o máximo possivel do todo: "Todo se dirá, constará en ellas...Todo será verdad... salvo que faltará la verdad esencial, aquella que jamás ninguna reconstrucción histórica podrá alcanzar, por perfecta y omnisciente que sea..." (p. 141) . Outra, inalcançável em sua totalidade e em sua essência, corresponde à vivência que não pode ser transmitida senão através da elaboração da mesma, senão mediante sua transformação em experiência: “_El otro tipo de 
comprensión, la verdad esencial de la experiencia, no es transmisible... O mejor dicho, sólo lo es mediante la escritura literaria..." (p. 141) A fala do professor possui muitas reticências referentes à ausência da qual ele trata, a de se atingir o âmago do horror, a essência da realidade. Yves, que havia começado a conversa, interpela a exposição do profesor como um bom aluno, de modo didático: "_Si he entendido bien - dice Yves -, jamás lo sabrán ¡los que no lo hayan vivido!" (p. 143) Segundo a exposição que o narrador faz da conversação, aquele que não viveu a catástrofe pode aproximar-se da compreensão da sua "verdad esencial", nos termos do professor, apenas por um meio lingüístico que leve em conta a impossibilidade de ver:

“_Jamás realmente... Quedan los libros. Las novelas, preferentemente. Los relatos literarios, al menos los que superen el mero testimonio, que permitan imaginar, aunque no hagan ver...Tal vez haya una literatura de los campos... Y digo bien: una literatura, no sólo reportajes..." (p. 143144)

As últimas palavras são do personagem-narrador:

“_ Tal vez. Pero el envite no estribará en la descripción del horror. No sólo en eso, ni siquiera principalmente. El envite será la exploración del alma humana en el horror del Mal... ¡Necesitaríamos un Dostoievski!” ( $p$. 144)

Tais palavras "sumen a los supervivientes, que no saben aún a qué han sobrevivido, en un abismo de reflexión.” (p. 144) Essa notação do narrador carrega uma dupla ambigüidade. Os companheiros deportados não sabem exatamente a que tipo de experiência sobreviveram e para quê sobreviveram. Além disso, "la exploración del alma humana en el horror del Mal..." leva-os a um "abismo de reflexión", ou seja, a uma interiorização nos próprios pensamentos e lembranças, que os deprime. Mas a imagem do "abismo de reflexión" também nos faz imaginar uma queda por um abismo cujas paredes são espelhos, cujo movimento descensional é acompanhado pela impossibilidade de ver outra coisa senão a si próprio caindo e vendo-se cair. Esse ensimesmamento inescrutável conforma a solidão e o silêncio do sobrevivente depois da experiência em Buchenwald captados pelo narrador no desenvolvimento da matéria. 
O episódio termina com a mudança de estado de espírito causada pelo som do trompete que "de pronto rompe a sonar". No fundo da sala, há um grupo de negros americanos do Exército Patton das forças aliadas. O personagem-narrador reconhece a frase inicial da canção de Armstrong tocada pelo grupo. Duas imagens significativas descrevem essa mudança súbita de ânimo: a "blancura de los manteles" e o "cristal de las garrafas vacías" que "reflejan la luz vacilante del sol naciente" (p. 144) e o reconhecimento da frase inicial do Big Buttler and Egg Man de Armstrong. A primeira imagem remete ao reflexo da luz do sol em ascensão ao qual se liga o jazz improvisado, "los soles" (ambiguamente em espanhol o plural de sol e solo musical) do grupo de negros. Os dois sóis, o imagético e o sonoro, suscitam no personagem-narrador a alegria necessária para tornar sua sobrevivência suportável. A música do jazz sobrepõe-se à angústia insuportável com a alegria solitária, reflexiva, ascensional.

Na seqüência, a narrativa encaixa uma história que, segundo o narrador, corresponde a uma lembrança do personagem-narrador, naquela manhã de abril de 1945 em Eisenach, ao ouvir os soldados norte-americanos tocarem um tema de Big Buttler and Egg Man de Armstrong. O mesmo tema musical, dois anos antes, tocava em uma festa de uma amiga que servira de refúgio a Koba, um amigo judeu da $\mathrm{MOI}$, grupo de choque da Resistência francesa ao qual o personagem-narrador pertenceu. Podemos apontar outra lógica, no entanto, que explica a evocação do narrador e a fragmentação desta narrativa. A história narrada exemplifica e traça um paralelo com a noção de como o tratamento literário do real pode ocupar o lugar do mero testemunho. ${ }^{75}$

\footnotetext{
${ }^{75}$ Antoni Munné defende a interpretação de que "en Semprún el hecho testimonial va siempre unido al hecho literario y no puede separarse de este último". Para o autor, o problema da arquitetura do texto narrativo criado por Semprún transcende o conteúdo do relato. Segundo Munné, o acúmulo de vivências que o escritor tem das catástrofes históricas de nosso século $\mathrm{xx}$ - a guerra civil espanhola, a segunda guerra mundial, a resistência ao fascismo e nazismo, a deportação a Buchenwald, a militância clandestina no PCE durante a ditadura franquista - permite-lhe fazer do trabalho sobre a memória relatos que tomam várias direções, mas que sempre estão às voltas com a forma de resgatar esse passado a partir da reflexão sobre o presente. Conforme a visão deste crítico, é desta maneira que vida real e ficção entrelaçam-se na obra de Semprún. In MUNNÉ, Antoni. "La memoria y la experiencia" in Quimera: Revista de Literatura, n. 14, Diciembre 1981, p. 76 .
} 
A idéia de lugar inventado ocupado oportunamente norteia o sentido da história de Koba. A festa na casa de uma amiga estudante de medicina serve de ocasião e lugar para esconder Koba, após uma ação de guerrilha em que seu amigo assassinaria um inimigo alemão influente. O lugar é arranjado pelo personagem-narrador, na ocasião Gérard, que lhe oferece o apartamento da festa cuja particularidade de ter duplo acesso adapta-se aos planos de Koba. Durante a festa, Koba conta ao personagem-narrador a operação. Ao entrar no quarto para matar o nazista, Koba depara-se com a presença "inoportuna" de uma prostituta junto ao nazista. Surpreso e contrariado, Koba mata também a mulher. $O$ personagem-narrador e seu amigo trocam entre si suas histórias de "mortes necessárias", a da mulher que acompanhava o nazista alemão e a do jovem soldado alemão que cantava "La paloma" e a de Alain, o agente inimigo infiltrado na rede Jean-Marie Action. Os três personagens mortos figuram nas histórias de Koba e do personagem-narrador como diferentes inimigos que se deparam, no momento e no lugar (in)devidos, com sua "morte necessária". Esses inimigos expressam nos seus olhares a condição do estranhamento, o pânico ou o assombro de terem sido atraídos ou caído acidentalmente nas malhas da morte. Suas presenças molestas exercem uma obsessão incômoda sobre seus narradores assassinos, ocupando um lugar estranho, repudiável, em suas memórias.

O narrador alude à invenção de um espaço de escrita literária cuja finalidade é abrigar outros desaparecidos incômodos de sua vida. Koba, "personagem inventado" na festa da amiga Hyacinthe, é substituído por Hans Freiberg, personagem judeu inventado pelo narrador escritor no lugar de Julien Bon, seu "amigo borgoñón" que se suicida ao cair em uma emboscada, a fim de ocupar "en (sus) novelas el lugar que Koba y otros amigos judíos han ocupado en (su) vida." (p. 150) A dialética entre ficção e realidade neste capítulo molda-se de acordo com seu leitmotiv, o da transposição enquanto operação substitutiva e dialética entre dimensões diferentes. Um jogo de substituições e sobreposições entre personagens reais e literários representa a concepção deste narrador, em 
que vida e obra, história e literatura, interpenetram-se através de um movimento dialético e dialógico.

No último fragmento, dois episódios entrelaçam-se e encaixam-se finalizando o capítulo e representando a aporia do regresso à vida como fusão do mundo concentracionário e do mundo exterior com a catástrofe: o da "borrasca de nieve" que cai sobre as bandeiras do desfile do $1^{\circ}$ de maio em Paris e o do testemunho oral em casa de Pierre-Aimé Touchard. A relação entre os dois episódios é antagônica. A tônica de cobrir, ocupar o lugar de, assume um sentido oposto em cada episódio quanto à possibilidade de regressar à liberdade da vida e testemunhar a "experiência da morte".

O fragmento começa narrando a antevéspera do $1^{\circ}$ de maio, o dia em que o personagem-narrador chegou a Paris. Nesta noite, passada em casa de PierreAimé Touchard, o sobrevivente fala longamente sobre sua experiência no campo. Mas a imagem que inicia o fragmento refere-se ao episódio do $1^{\circ}$ de maio. $A$ primeira frase do fragmento repete o modelo sintático descritivo que inicia os capítulos desta primeira parte do romance: "Una borrasca de nieve, de golpe, sobre las banderas del $1^{\circ}$ de mayo." (p. 150). Ao contrário da frase musical de Armstrong - On the sunny side of the street -, não é o sol que está sobre o personagem-narrador, mas sim a neve que de repente o cobre e cobre sua visão do presente com a lembrança do passado recente de Buchenwald. Neste episódio, a imagem da neve, lembrança obsessiva do narrador, assume um valor metonímico e metafórico e converte-se em imagem psicológica do personagemnarrador. Enquanto lembrança involuntária do personagem-narrador, a imagem atua como força inconsciente capaz de influenciar e transformar sua trajetória.

Em casa de Pierre-Aimé Touchard, Pat, o sobrevivente fala, a primeira e última vez em dezesseis anos, detalhada e longamente sobre Buchenwald. O estímulo advém do silêncio "amistoso, abierto", de seu amigo, valorizado positivamente pelo narrador em oposição às perguntas superficiais e evasivas do outro tipo de interlocutor descrito. Mas o fato de o personagem-narrador começar a falar da experiência em Buchenwald deve-se antes à reação de Jeanine, 
namorada de Yann Dessau, companheiro de Buchenwald que não havia ainda retornado.

Ao entrar na casa de seu padrasto e ver o personagem-narrador, Jeanine primeiro fica petrificada

"como si hubiera visto un aparecido, pondría en una novela de quiosco de estación ferroviaria. Pero es que realmente era un aparecido lo que estaba viendo. $Y$ es que la vida, a menudo, es como una novela de quiosco de estación." (p. 152)

A ironia do narrador insiste na função inapropriada da palavra sobrevivente cujo significado equívoco para a sua condição leva-o a substituí-la por "aparecido". Em seguida, a jovem começa a "llorar silenciosamente, con las manos cruzadas ocultando su rostro". Neste gesto, a dor de ver o não visto é expressa pelo silêncio que encobre o pranto e pelas mãos que ocultam as lágrimas. O Mal do campo aparece sob a forma da ausência do namorado, evidenciada pelo reaparecimento do personagem-narrador. O Mal do campo é representado duplamente em forma de ocultamento.

As razões que o narrador dá de seu primeiro testemunho oral são reunidas num discurso dubitativo:

"Entonces, (...) empecé a hablar. Quizá porque nadie me pedía nada, porque nadie me hacía preguntas, porque nadie me exigía cuentas. Quizá porque Yann Dessau no regresaría y había que hablar en su nombre, en nombre de su silencio, de todos los silencios: miles de gritos ahogados. Quizá porque los aparecidos tienen que hablar en el lugar de los desaparecidos, a veces, los salvados en el lugar de los hundidos." ( $p$. 154)

É clara a alusão à expressão de Primo Levi, título de seu livro Os afogados e os sobreviventes. A citação atende a uma interpretação da obra e do ato de testemunhar de Primo Levi pela qual o narrador reforça sua posição como testemunha e escritor da Shoah junto à corrente que afirma a possibilidade e, mais que isso, a necessidade da representação estética deste evento histórico. Mas na maneira como o narrador inclui essa alusão, a concepção de testemunho liga-se à situação narrativa enquanto fator psicológico que move os atos de fala do personagem-narrador constitutivos das ações deste enredo. 
A testemunha fala a partir de um lugar incômodo, inapropriado, pois sentese no lugar do namorado de Jeanine. Fala "hasta el alba", até ficar sem voz, até atingir o espaço do silêncio por esgotamento da voz. E fala não só em nome de Yann, mas "en su silencio", para devolver-Ihe a palavra extinta. A imagem expressa a palavra da testemunha sobreposta ao silêncio dos naufragados até revestir, em forma de silêncio, a voz não ouvida dos mortos.

Mas o que autoriza ao sobrevivente testemunhar no lugar da "testemunha integral" está representado pelo primeiro episódio. Após sair atormentado da casa de Claude-Edmonde Magny, em meio à manifestação do $1^{\circ}$ de maio em Paris de 1945, cai a neve quando um grupo de deportados chega à avenida desfilando com seus uniformes listrados. Junto ao "rumor de los cantos antiguos" e das "banderas rojas", o personagem-narrador verifica que "había vuelto", "estaba vivo". Mas "una tristeza" que oprimia seu coração, "un malestar sordo y punzante", distinto do sentimento de culpa de ter sobrevivido, abate-se sobre seu espírito sem poder ser compreendido por ele. Somente após a queda da "borrasca de nieve" sobre as bandeiras, ele identifica a causa de sua inoportuna angústia:

"El mundo se borró a mi alrededor en una especie de vértigo. Las casas, la multitud, París, la primavera, las banderas, los cantos, las consignas coreadas: todo se borró. Comprendí de dónde provenía la tristeza que me afligía, a pesar de la impresión engañosa de estar ahí, vivo, en la Place de la Nation, aquel 1 de mayo. Y es que precisamente no estaba del todo seguro de estar ahí, de haber vuelto realmente." (p. 156)

A tormenta de neve, caída sobre a manifestação dos trabalhadores e sobre a comitiva dos deportados que desfilavam, arrasta-o sob uma sensação de queda vertiginosa à recordação da neve no Ettersberg. A lembrança da neve no Ettersberg sobrepõe-se à visão da neve nas bandeiras do desfile e cobre suas certezas de ter sobrevivido ao mesmo tempo em que esclarece a origem de sua angústia. É por conhecer intimamente o ato de a morte passada "ocupar" o lugar da vida presente, apagá-lo, que esta testemunha sente-se autorizada a falar no lugar do desaparecido, daquele que foi apagado do presente da enunciação. Mas neste momento de sua história, a neve que cobre sua felicidade impede-o de 
superar sua vivência e de transpô-la ao mundo sob a forma de experiência elaborada literariamente.

\section{Antítese: a camuflagem como aporia do regresso da vida}

Vista em seu conjunto, a segunda parte do romance está em uma relação dialética com a primeira. As conseqüências negativas do universo concentracionário sobre o sobrevivente radicalizam-se engendrando sua negação através da sua camuflagem no mundo exterior. O personagem-narrador nega sua identidade de sobrevivente do Holocausto escondendo-a e assim camuflando-se sob a aparência de uma outra identidade em que a primeira se ausenta. $\mathrm{O}$ "fantasma" que surge do campo oculta sua história de ter atravessado a morte, silenciando-a para si e para o mundo ao qual pretende pertencer como vivo. A camuflagem do personagem-narrador sob a tentativa de esquecer sua história em Buchenwald representa a impossibilidade de luto, de elaborar a morte vivenciada.

A narrativa avança pouco no tempo da história. No sexto capítulo, "El poder de escribir", o personagem-narrador, de volta a Paris, no verão de 1945, ao passar a noite com sua amante Odile, tem um pesadelo com Buchenwald e acorda sobressaltado, com o coração acelerado, angustiado. Volta ao bar onde tocavam jazz, esperando amanhecer para bater à porta de Claude-Edmonde Magny. A amiga recebe-o, serve-lhe café e lê para ele uma carta, dirigida a ele em função das paródias de Mallarmé que ele escrevera antes da reclusão em Buchenwald. $O$ diálogo com a amiga, entrecortado com a leitura da carta, revela o esgotamento do sobrevivente, à beira do suicídio, e sua incapacidade de falar a respeito da experiência no campo de concentração. A carta exprime a necessidade de elaboração da experiência no processo de escrita literária.

No capítulo "El paraguas de Bakunin", três meses depois, o personagemnarrador está em Ascona, retirado em casa da família a fim de escrever o 
testemunho literário sobre Buchenwald. Numa viagem de renovação de visto, ele conhece Lorène com quem estabelece um relacionamento amoroso no qual dissimula sua identidade de sobrevivente do Holocausto. Sem sabê-lo, Lorène ajuda-o a encontrar uma maneira de tentar esquecer o passado do campo e dar uma trégua ao tormento traumático da experiência. Quando Lorène mostra-Ihe o guarda-chuva de Bakunin, esquecido em casa de sua família, ele tem uma idéia reveladora sobre como poder esquecer Buchenwald. Ao final, ele volta a Paris e abandona seu projeto de testemunho literário.

A segunda parte de La escritura o la vida problematiza a memória de Buchenwald sob a dialética entre lembrar e esquecer. A proposição alternativa de lembrar ou esquecer, escrever ou silenciar, viver ou morrer, não faz jus ao sentido dialético negativo da questão, que passa ao largo da crítica da obra de Jorge Semprún. A respeito deste dilema, Harald Weinrich, por exemplo, afirma que

"Pelo seu conteúdo o título do livro poderia ser: 'lembrar ou esquecer',
pois meio século depois Jorge Semprún teve de escolher entre deixar por
escrito suas torturantes memórias e um esquecimento libertador, que lhe
possibilitaria continuar vivendo sem problemas (choisir entre l'ecriture et
la vie)." ${ }^{76}$

Mas se o cerne da aporia do testemunho de Semprún neste romance corresponde ao dilema de lembrar ou esquecer sua experiência em Buchenwald, esse dilema aporético não ocorre à maneira de uma escolha que envolva um "esquecimento libertador", possibilidade da continuidade de uma vida "sem problemas". O personagem-narrador, nos primeiros meses após sua libertação de Buchenwald, não tem a liberdade que a palavra choisir implica, pois não apresenta condições psicológicas para lidar com as lembranças de Buchenwald através da escrita. O sobrevivente mostra-se dilacerado entre lembrar e esquecer. Ele não opta por esquecer para viver sem problemas. Ao contrário, ele precisa rechaçar as lembranças, empenhar-se na empresa impossível que é esquecer a experiência em Buchenwald, para manter-se com vida, ainda que com uma vida mutilada. Segundo o narrador, o eu autêntico do personagem-narrador é aquele originário

\footnotetext{
${ }^{76}$ WEINRICH, Harald. "Lutar com o esquecimento (Primo Levi, Jorge Semprún)", Lete-Arte e crítica do esquecimento. Trad. Lya Luft. Rio de Janeiro: Civilização Brasileira, 2001, p. 264.
} 
da experiência do Holocausto e desejado enquanto escritor. Este eu é reprimido e negado nesse esforço de recalque das lembranças e da atividade da escrita literária testemunhal.

Do ponto de vista de seu movimento interno, os capítulos que formam a segunda parte do romance encontram-se em uma relação antitética. $O$ sexto capítulo privilegiará a negatividade das lembranças de Buchenwald, a impossibilidade do luto, ao passo que "El paraguas de Bakunin" narra como o sobrevivente estabelece o silêncio, o esquecimento e a renúncia à escrita como modo de negar o rememorar e, portanto, afirmar-se mediante a negação de si mesmo. Se no sexto capítulo acompanhamos como essas lembranças roubavam a tranqüilidade, o sono, as forças de viver do personagem-narrador, no sétimo capítulo, seguiremos o curso de acontecimentos que podem oferecer-lhe esta trégua por meio de furtos e embustes compensatórios da memória. Assim, o esquecimento também será enfocado à luz da negatividade. O esquecimento aparece como um ladrão de tesouros da memória, uma ars oblivionis que apazigua o espírito às custas de solapá-lo. Os episódios do sexto capítulo ligamse ao tormento de lembrar e à impossibilidade de esquecer; os do sétimo referemse a maneiras enganosas de esquecer. As metáforas do lembrar, a freqüência de expressões como "me acuerdo" e "recuerdo" recheiam "El poder de escribir"; enquanto a metáfora de roubar, de obsequiar lembranças e atenção e a expressão "he olvidado" e similares estão presentes na história do "paraguas de Bakunin". Da mesma maneira, Claude e Lorène representam respectivamente funções da dialética entre lembrar e esquecer. Por meio dos diálogos e das ações que se desenvolvem com estas personagens, o romance representa a necessidade de um auto-estranhamento do personagem-narrador, de desconhecer a identidade originária do campo, para identificar-se com o mundo.

Da problematização dialética do lembrar e do esquecer que se interpenetram na memória do sobrevivente decorrem outros pares dialéticos como perder e ganhar, apagar e inscrever, claro e escuro, superficial e profundo, felicidade e angústia, sonho e realidade, ser e nada, o mesmo e o outro, inocência/ignorância e conhecimento/responsabilidade, tranqüilidade e 
desassossego, real e fictício, concreto e abstrato, espiritual e carnal, poder e nãopoder lembrar/escrever/viver, absurdo e sensatez, violência e ternura, opacidade e transparência, enterrar e desenterrar, emergir e submergir, suportar e sucumbir.

\subsection{A lembrança que sepulta}

No capítulo "El poder de escribir", a cena central da carta de ClaudeEdmonde Magny constitui o núcleo da ação que representa a impossibilidade de o sobrevivente falar, escrever e elaborar sua experiência do Holocausto e ao mesmo tempo a impossibilidade de esquecê-la. A narrativa delineia um movimento dialético que parte da lembrança involuntária da morte inesgotável que o leva ao esgotamento da vontade de viver e deste ao esquecimento voluntário da "vivência da morte". A representação da associação livre da memória é um recurso aparente que oculta a lógica dialética que organiza os fragmentos. $O$ vai e vem fragmentário da narrativa representa o retorno intermitente do campo em forma de lembranças, que nega um retorno definitivo do sobrevivente ao mundo. As lembranças involuntárias e inconscientes do campo vão intensificando-se até atingir um paroxismo que engendra o contrário, sua diminuição progressiva em função do aumento da vontade consciente de esquecê-las. A narrativa apresenta uma ambivalência semântica de imagens do branco que perfila o sentido dialético da ação. $O$ branco da neve desprende a ambigüidade da presença emblemática da morte do campo, mas também de apagar a memória da morte com a página em branco do esquecimento, com a negação da escrita. Embora ainda muito colado à perspectiva do jovem Semprún de 1945, o ponto de vista do narrador fazse mais presente. O emprego do presente verbal para narrar o passado de 1945 escasseia-se, enquanto as digressões tomam mais espaço na narrativa.

O quadro do primeiro fragmento anuncia o sentido da ação representada no capítulo. Por um lado, Claude-Edmonde Magny lê uma carta que escrevera há dois anos ao personagem-narrador, cujo título Lettre sur le pouvoir d'ecrire prenuncia, por oposição, a perda do poder de escrever de seu interlocutor. $O$ personagem-narrador desdobra-se em um duplo interlocutor, o da carta e o de sua 
leitura. Por outro lado, ele olha o céu azul que cobre o cemitério de Montparnasse onde jaz em seu túmulo o poeta César Vallejo. Enquanto ouve a leitura da carta e olha o céu sobre o túmulo do poeta, ele evoca em silêncio um verso do poeta que responde ambiguamente à carta de Claude e ao diálogo que se desenrola a partir da mesma: "En suma, no poseo para expresar mi vida, sino mi muerte..." (p. 160) 77

As omissões contraditórias adensam-se nesta cena. Na carta de dois anos atrás, Claude apontava que nas paródias que o personagem-narrador fazia de Mallarmé havia a ausência de si: "Se preguntaba usted qué les faltaba a esas extraordinarias parodias de Mallarmé (...) haber sido escritas por usted mismo..." (p. 159) A carta de Claude recupera uma identidade passada do personagemnarrador ligada à escrita em que, contudo, sua identidade está ausente. A carta é

77 En suma, no poseo para expresar mi vida...

En suma, no poseo para expresar mi vida, sino mi muerte.

$\mathrm{Y}$, después de todo, al cabo de la escalonada naturaleza y del gorrión en bloque, me duermo, mano a mano con mi sombra.

Y al descender del acto venerable y del otro gemido, me reposo pensando en la marcha impertérrita del tiempo.

¿Por qué la cuerda, entonces, si el aire es tan sencillo? ¿Para qué la cadena, si existe el hierro por sí solo?

César Vallejo, el acento con que amas, el verbo con que escribes, el vientecillo con que oyes, sólo saben de ti por tu garganta.

César Vallejo, póstrate, por eso, con indistinto orgullo, con tálamo de ornamentales áspides y exagonales ecos.

Restitúyete el corpóreo panal, a la beldad; aroma los florecidos corchos, cierra ambas grutas al sañudo antropoide, repara, en fin, tu antipático venado; tente pena.

¡Que no hay cosa más densa que el odio en voz pasiva, ni más mísera ubre que el amor!

¡Que ya no puedo andar, sino en dos harpas!

¡Que ya no me conoces, sino porque te sigo instrumental, prolijamente!

¿Que ya no doy gusanos, sino breves!

¿Que ya te implico tanto, que medio que te afilas!

¿Que ya llevo unas tímidas legumbres y otras bravas!

Pues el efecto que quiébrase de noche en mis bronquios, lo trajeron de día ocultos deanes y, si amanezco pálido, es por mi obra; y, si anochezco rojo, por mi obrero. Ello explica, igualmente, estos cansancios míos y estos despojos, mis famosos tíos. Ello explica, en fin, esta lágrima que brindo por la dicha de los hombres.

¡César Vallejo, parece

mentira que así tarden tus parientes,

sabiendo que ando cautivo,

sabiendo que yaces libre!

¡Vistosa y perra suerte!

¡César Vallejo, te odio con ternura!

César Vallejo

VALleJO, César. Obra Poética Completa. AGUIRRE, Enrique Ballón. (editor, prólogo y cronología) Obra Poética Completa - César Vallejo (1892-1938). Caracas, Venezuela: Biblioteca Ayacucho, 1985, p. 168-169. 
um registro que rememora uma escrita em que o sujeito da escrita não consegue registrar suas memórias. O ato de leitura epistolar de Claude desdobra-se na memória da escrita e na escrita da memória, na ausência da identidade em forma de vida e na presença da identidade em forma de morte, na ausência do eu na escrita e na ausência da escrita no eu. Antes da experiência da morte em Buchenwald, na escrita do personagem-narrador não se inscreve sua identidade porque Ihe falta experiência de vida. As paródias de Mallarmé são também paródias do eu como um falso texto que frauda a presença da identidade do sujeito da escrita. As paródias de Mallarmé tornavam os escritos de Mallarmé presentes porque o sujeito das paródias estava ausente. Agora, o sobrevivente encontra-se também ausente como interlocutor desta mensagem de ausência.

A contemplação do céu azul que encobre o túmulo de César Vallejo e a simultânea recordação de seus versos desvelam a necessidade de o sobrevivente enterrar o doloroso passado de Buchenwald como lembranças mortas no túmulo do esquecimento e ao mesmo tempo a impossibilidade de tomá-las como mortas para o presente de sua vida. ${ }^{78}$ A recordação dos versos de Vallejo substitui, de certa maneira, a incapacidade de o sobrevivente naquele momento expressar-se sobre sua "experiência da morte". Como no terceiro capítulo do romance, a recitação lírica nesta situação representa um esforço de compensar a impossibilidade de o sobrevivente elaborar o recente passado traumático. $O$ personagem-narrador vai dar à casa de Claude num estado de letargia e ausência expresso por seu silêncio pesado diante da amiga: "El cansancio de vivir pesaba aquella mañana. La angustia del despertar en plena noche, de la huida insensata subsiguiente, todavía oprimía el corazón." (p. 163)

Desde o terceiro até o sexto fragmento, a narrativa contextualiza a cena da carta reconstituindo o encontro anterior do personagem-narrador com Odile. O fluxo narrativo é análogo à descrição do fluxo sangüíneo do personagem-narrador, que vai oprimindo seu coração até fazê-lo despertar no meio da noite. Alguns

\footnotetext{
${ }^{78}$ Jean-Marie Gagnebin observa que a etimologia da palavra sema possui dois significados: túmulo e signo, o que para a autora evidencia que "todo o trabalho de pesquisa simbólica e de criação de significação é também um trabalho de luto". Segundo a autora, as inscrições funerárias como primeiros rastros de signos confirmam a relação inseparável entre memória, escrita e morte. In GAGNEBIN, Jean-Marie. "Verdade e memória do passado" in Lembrar, escrever, esquecer. São Paulo: Editora 34, 2006, p. 45.
} 
eventos vão adensando uma rede de significações cujo clímax é atingido no quinto fragmento que desemboca no seu despertar angustioso. A série de imagens ambíguas do branco indicia o desassossego progressivo do personagem-narrador que culmina no seu pesadelo sobre o campo e subseqüente despertar.

Desde seu regresso a Paris, ele vê com freqüência Odile. Sem residência fixa, os encontros ocorrem em lugares variados e improvisados. No contexto de pós-guerra, o sobrevivente vive o cotidiano. No começo de agosto, eles encontram-se num amplo apartamento vazio cujos móveis estão cobertos por capas brancas. A visão dos móveis cobertos de branco causa-lhe "un confuso desasosiego", "un malestar fugitivo, tibio, algo pegajoso, que (le) rozaba el alma", "un malestar callado". Mas não se trata ainda de um "vuelco del corazón, ningún latido repentino de la sangre" (p. 165), embora esta suave angústia já denuncie sua fragilidade e vulnerabilidade em face da "felicidad de vivir". Tal inquietação é provocada pela lembrança da infância que irrompe com a visão dos móveis cobertos de branco. Ele se recorda das capas brancas que cobriam os móveis de sua casa de infância em Madri quando retornava com sua família das viagens de verão às praias do mar Cantábrico. Lembra-se principalmente do último veraneio que terminou com o exílio da família em função da Guerra Civil Espanhola. O desassossego sentido pela criança que experimentou a violenta instabilidade política em Madri é coberto pela sensação de incerteza de voltar à casa do exprisioneiro. A deportação a Buchenwald é assimilada em termos de matriz mnemônica para a qual outras formas de desenraizamento do personagemnarrador concorrem. ${ }^{79} \mathrm{O}$ branco fantasmagórico da morte em Buchenwald envolve

\footnotetext{
${ }^{79}$ Ofelia Ferrán explora a influência do exílio na vida e na obra deste escritor madrileno. A autora observa que o primeiro exílio de Semprún dá-se com o desastre da Guerra Civil Espanhola para os republicanos, mas que a experiência mais radical de exílio por ele experienciada corresponde à deportação a Buchenwald: "exílio hasta el borde de la muerte, es la que le vuelve a acechar repetidamente en el recuerdo". Os três tipos de exílio identificados por Ferrán na vida de Semprún - o político, o do Holocausto e o literário com o bilingüismo são abordados neste capítulo do romance, sofrendo interpenetrações e sobreposições. Segundo Ferrán, Semprún faz da linguagem sua única pátria, o que implica por princípio uma instabilidade permanente, já que a linguagem e a escritura exigem um constante processo de (re)criação. Quando Semprún explica que escrever em francês é fazer do exílio uma pátria, ele quer dizer também que a invenção lingüística assemelhase ao exílio na medida em que seu solo está em permanente reelaboração, permanente ressignificação. Essa, sem dúvida, é uma positividade fundamentada na negatividade da instabilidade. Ferrán afirma que o exílio do sobrevivente prossegue quando liberto: "Estos supervivientes pasan de un exilio terrible sufrido con su encarcelamiento a un exilio que continuarán sufriendo mientras su recuerdo les siga 'deportando' al universo
} 
como capas de neve tanto os móveis do apartamento quanto os da casa de infância e as mortalhas dos corpos mortos de Buchenwald: "No había vuelto a ver, nunca volvería a ver las amplias estancias de muebles fantasmagóricos, cubiertos con fundas blancas como mortajas." (p. 166)

Por antagonismo, o branco também evoca imprecisa e intermitentemente as imagens de leveza e de felicidade da infância, que pouco a pouco vão se definindo na memória do personagem-narrador: "¿Alas de gaviotas, al alba, tras los ventanales de una habitación de hotel en Bretaña?" precisam-se em "las gaviotas de Bretaña"; ¿Foques de veleros bajo la luz de estaño de la bahía de Formentor? definem-se em "las velas de Formentor"; ¿Nieblas lechosas, deshilachadas por los vientos arremolinados en el estrecho de Eggemogging?” são identificadas com “ las nieblas de Little Deer Isle." (p. 168-169)

A presença de Odile situa-se ao lado dessas lembranças felizes de infância. Sua leveza e alegria devolvem o prazer à vida do sobrevivente que, não obstante, pode ser ameaçado pela "memoria de la muerte, su sombra traicionera, (que le) daba alcance a ratos. En medio de la noche, preferentemente." (p. 169) As expressões "pese a", "a pesar de" começam a aparecer com maior freqüência no capítulo e conjugam o sentido concessivo de as lembranças de Buchenwald subtraírem-lhe a vontade de viver com o sentido de pesar, de dor, que se associa ao peso insuportável desta memória. Se a leveza do branco antagoniza com a presença sombria da morte, também a evoca mediante imagens de exílio e desassossegos.

O quinto fragmento trata do despertar sobressaltado do personagemnarrador que resulta em sua visita a Claude. Ele tem um sonho recorrente referente a um acontecimento repetitivo nos últimos meses antes da retirada dos nazistas de Buchenwald. Em meio a uma noite de ataque aéreo das forças aliadas, enquanto dormia com os companheiros moribundos no barracão, a ordem de apagar os crematórios, emitida pelo megafone do campo, invadia seu sonho,

concentracionario que no logran, fácilmente, dejar atrás.” In FERRÁN, Ofelia. “El largo viaje’ del exilio: Jorge Semprún” in SOLER, Manuel Aznar (ed.) El exilio literario español de 1939. V. 2, Serpa Pinto. 1. Barcelona, Spain: Grup d'Estudis de l'Exili Literari, Departament de Filologia Espanyola, Universitat Autònoma de Barcelona (GEXEL), 1998, p. 107. 
despertando-o. O episódio do despertar integra a dialética entre o sonho e a realidade, a pátria e o exílio, a morte e a vida, acrescentando mais ambigüidade às imagens mnemônicas do branco. O despertar é fruto da contradição de estar adormecido para a vida fora do campo ao não poder adormecer nela seu passado em Buchenwald e de ter sempre acordado Buchenwald no consciente ao sonhar com ele enquanto dorme. Nesta situação, o despertar mostra como a experiência do campo modificara suas lembranças da infância e sua percepção do presente, invertendo o sentido do real e do fantasioso, causando dano ao princípio de discernimento do prazer e da dor:

"Me desperté sobresaltado a las dos de la madrugada. <Desperté> tampoco es el término más adecuado, aunque sea exacto. Pues efectivamente salí, de un sobresalto, de la realidad del sueño, pero tan sólo para sumirme en el sueño de la realidad: la pesadilla, mejor dicho." (p. 169)

O sonho de Buchenwald equivale à realidade (do sonho da vida), enquanto a vida é igual ao sonho (da realidade de Buchenwald). $\mathrm{Na}$ interpretação do narrador, seu despertar atende a um chamado da consciência, adormecida no sono, que parte do inconsciente - "Krematorium, ausmachen!" - o qual a adverte de que ela em vigília continua "apagada", uma vez que se ilude com as "apariencias", os "simulacros y melindres de la existencia", procurando esquecer sua história de sobrevivente de Buchenwald. ${ }^{80}$ Trata-se de uma memória latente que se rebela contra a consciência que tenta bani-la do cotidiano, o que faz com que ela invada essa consciência durante o sono quando se afrouxa. Essa memória intrusa, profunda, insubmissa do inconsciente provoca-lhe uma sensação de serenidade e de paz comparada pelo narrador àquela que se sentiria por pertencer a "una especie de patria, el lugar designado de una plenitud, de una coherencia vital, pese a la voz autoritaria (...) Krematorium, ausmachen!" (p. 170)

\footnotetext{
${ }^{80} \mathrm{O}$ texto de Cathy Caruth analisa as formas simbólicas e ao mesmo tempo factuais que o sonho de um trauma assume. Aquele que possui o trauma ao sonhar com ele desperta para a responsabilidade ética com relação ao real. O estudo baseado em Freud e Lacan coincide com o sentido que o despertar do romance toma nessa situação narrativa. Para a autora, o acordar que o sonho do trauma suscita reencena uma resposta atrasada, uma omissão traumática que envolve um despertar da consciência como tomada de responsabilidade com relação à natureza da sobrevivência. Segundo Caruth, o sonho que desperta ou o despertar dentro do sonho traumático do sobrevivente concerne a um imperativo ético próprio do sobrevivente. In CARUTH, Cathy. "Modalidades do despertar traumático (Freud, Lacan e ética da memória)" in NESTROVSKI, Arthur e SELIGMANN-SILVA, Marcio (orgs.). Catástrofe e representação. São Paulo: Escuta, 2000, p. 111-136.
} 
De maneira ambivalente, a memória traumática de Buchenwald também é a memória da pátria possível, o que para aquele que se considera um apátrida e eterno exilado significa a inversão de a dor e o trauma se transformarem no solo familiar e seguro do mundo. ${ }^{81}$

O motivo auditivo da voz de ordem de Buchenwald no pesadelo do personagem-narrador também encontra indícios nas circunstâncias desta noite. Horas antes, no Petit Schubert, ele reconhece a música Stardust, de Armstrong, também tocada pela orquestra de jazz de Jiri Zak em Buchenwald, o que o faz perder o equilíbrio. A sensação de desamparado físico é entendida pelo narrador como "una señal". As lembranças da neve e da fumaça cinza do crematório de Buchenwald integram a série de imagens brancas evanescentes: "Pero había copos de nieve flotando en mi memoria. O tal vez fueran pavesas de humo gris." (p. 171) A assimilação das memórias da infância pelas de Buchenwald tem o retorno à casa da infância como o primeiro despertar para a perda do lar, o primeiro fato que the dá uma consciência de desamparo contraditoriamente através do regresso à intimidade da casa. Buchenwald significa para esta testemunha a mais radical experiência de perda do lar e isso se expressa na sua transformação no único lar possível. As memórias de Buchenwald tornam-se uma nova infância temida e recusada pelo personagem-narrador para libertar-se da dissolução do eu à qual a infância-Buchenwald arrastava-o.

A partir do sexto fragmento, o capítulo apresenta as manifestações da memória de Buchenwald sob a dialética da doença e da cura, da ausência e da presença, da inocência e da culpa, da perda e da salvação, sublinhando seu aspecto negativo. Acordado ao lado de Odile, o personagem-narrador a observa adormecida. A memória do desastre aliada à sombra, à escuridão, ao peso e ao silêncio opõe-se à presença de Odile associada à leveza, à claridade, ao frescor e ao canto. A imagem da personagem nos sugere a de uma borboleta: "revoloteando" pelo salão, lançando as capas brancas que a envolvem como

\footnotetext{
${ }^{81} \mathrm{O}$ campo de concentração como pátria comporta uma ironia perversa nesse capítulo, pois o sobrevivente, como observa Valeria De Marco, é aquele que vive na condição permanente de desabrigado, já que perdeu a confiança no mundo. Se esse sobrevivente toma o campo de concentração como o lugar familiar, a pátria, conhecendo sua hostilidade, é porque ele se tornou um eterno estrangeiro e o mundo um pesadelo.
} 
aureola. Odile encarnava a inocência para o ex-prisioneiro. ${ }^{82} \mathrm{O}$ sono de Odile é caracterizado por "la lánguida plenitud del reposo" e sua beleza transmite ao personagem-narrador uma "certidumbre sosegante". Os adjetivos que qualificavam o estado do personagem-narrador ao sonhar com Buchenwald, acordado passam a caracterizar o sono de Odile. Com o sobrevivente fica uma dor sem distração, intransferível, da qual somente o suicídio seria capaz de livrá-lo. A memória de Buchenwald apresenta-se neste momento como uma dor incontornável cuja morte como solução postula o problema da dialética entre a memória e a morte. Para o personagem-narrador, a memória da morte levava à morte da memória, irrevogavelmente, pois se daria ou em forma de óbito pessoal ou de esquecimento, uma outra forma de morte.

Esta memória é descrita como um animal traiçoeiro, uma tormenta inesperada, que o atingia "abocando(lo) a un silencio agarrotado", momentos esses em que Odile desequilibrava-se e "perdía pie". A imagem sugere a situação de um predador agarrando sua presa. A camuflagem esboça-se como saída para escapar da morte. A narrativa ressalta a inaptidão da amante para agüentar 0 peso do desastre, para "escuchar las voces de la muerte", habilidade pouco disponível naquele contexto de pós-guerra: “¿Pero estuvo alguien disponible, en nuestro entorno, en aquellos momentos del regreso, para prestar un oído incansable y mortal a las voces de la muerte?" (p. 173) A dificuldade em comunicar o peso desta dor tornava-a insuportável à testemunha.

O personagem-narrador volta insone ao Petit Schubert. O conjunto de jazz continua tocando Armstrong. Ao amanhecer, a sala fecha-se, ele sai, deita-se num banco de um parque. O narrador explica-nos como a música do jazz foi sendo gerida em sua mente desde a festa em Eisenhach como matriz de sua narrativa sobre Buchenwald. Primeiramente, ele fala de "una intuición" que o "había ido invadiendo". A imagem recupera o fluxo que aumenta progressivamente em

\footnotetext{
${ }^{82}$ Podemos notar na obra de Semprún a recorrência de algumas figuras que fazem parte de sua poética. A leveza da vida é com freqüência representada pela metáfora da borboleta e comparada ao sorriso feminino. Em Viviré con su nombre, morirá con el mío, temos esta passagem ilustrativa: "Me dan ganas de llorar de alegría: es muy ligera, una pluma, una mariposa, una sonrisa de mujer, una nube algodonosa en el cielo azul." In SEMPRÚN, Jorge. Viviré con su nombre, morirá con el mío. Trad. Carlos Pujol. Barcelona: Tusquets, 2002, p. 76.
} 
intensidade. Depois realça qualidades antagônicas deste gênero musical - "solos desolados o irisados", "baterías apagadas o tónicas" -, comparando-as com "los latidos de una sangre vivaz" que "se situaban paradójicamente en el centro del universo que quería describir". A imagem de um coração pulsante, cujos movimentos alternados de contração (pausa e silêncio) e de dilatação (batimento e voz solitária) dão vida ao organismo, representa o que ele chama de paradoxo central do universo concentracionário. De intuição, o jazz passa a ser objeto de reflexão do jovem intelectual que já havia ensaiado antes da deportação a Buchenwald alguns escritos literários e demonstrava não ser um leitor leigo:

"La música constituiría su materia nutricia: su matriz, su estructura formal imaginaria. (...) La música, las diferentes músicas, acompasarían el desarrollo del relato. Un domingo, ¿por qué no? El relato de una jornada de domingo, hora por hora." (p. 174-175)

O substrato temporal mínimo de um dia expandido a partir de flashbacks e prolepses formaria a concepção de sua narrativa. Mas a matriz imaginária formal que deveria estruturar a matéria supunha um grau de abstração, um distanciamento racional e um equilíbrio emocional dos quais o personagemnarrador estava longe. $\mathrm{O}$ descompasso de seu batimento cardíaco opunha-se ao ritmo acompassado da música:

"Cuando me despertaba a las dos de la madrugada con la voz del oficial S.S. en el oído, con la llama anaranjada del crematorio cegándome los ojos, la armonía sutil y sofisticada de mi proyecto se hacía añicos entre brutales disonancias. Sólo un grito que proviniera del fondo de las entrañas, sólo un silencio de muerte habría podido expresar el sufrimiento." (p. 175)

A imagem do sofrimento visceral contrapõe-se e ultrapassa a capacidade de estetização, a liberdade da imaginação abstrata da forma artística. A memória assume a imagem metonímica e metafórica de uma palpitação acelerada, irregular, de uma dor que se irradia das regiões cavernosas das entranhas. No entanto, essas figuras antes se subordinam à referência factual: o sobrevivente é despertado pela intensificação do seu batimento cardíaco durante um pesadelo com Buchenwald. O grito (dilatação) e o silêncio de morte (contração) advindos das entranhas correspondiam a uma dilatação excessiva, informe, e a uma 
contração total, aniquiladora. Esse silêncio e esse grito eram a própria dor do silêncio e do grito como pulsões quase terminais de seu corpo. ${ }^{83}$

Do oitavo ao décimo fragmento, a narrativa retoma a conversa com Claude e o "olvido" vai ganhando espaço como conseqüência dos fatos relatados. Os verbos "guardar(me)", "conservar", "desaparecer", "borrrar" aparecem com maior freqüência, indicando que o esquecimento vai revestindo as lembranças.

O personagem-narrador conta a Claude seu "despertar en plena noche: sus razones, su sinrazón". Depois de ouvi-lo, ela recomeça a leitura da carta:

“... les faltaba sencillamente haber sido escritas por usted. Que estuviera relacionado en cierto modo con lo que hay de esencial en usted, con esa cosa que usted quiere por encima de todo..." (p. 176)

Então ela pára e pergunta-lhe se ele já sabe o que "quiere por encima de todo" (grifo nosso), se ele conhece agora aquela parte essencial ausente em suas paródias de Mallarmé. Sua resposta é incompleta e reticente: “_Creo saber..." (p. 176) O que é silenciado para sua interlocutora é o próprio desejo de silenciar sua parte essencial: "Lo que quisiera por encima de todo es el reposo (...) el reposo espiritual. El olvido, dicho de otro modo" ( p. 176, itálico nosso), pensa em silêncio.

O esquecimento corresponde a uma transformação da lembrança no movimento desta parte da narrativa. Os estados psicológicos do personagemnarrador radicalizam-se, gerando a conversão das lembranças em esquecimento. Segundo o narrador, seu desassossego alimentava-se tanto das alegrias da vida quanto das lembranças da morte no campo. Era na relação "presente" do personagem-narrador com aquelas lembranças que a angústia se instalava. Tratava-se de uma inaptidão a viver o presente em função de um aprisionamento ao passado como uma realidade cristalizada que comandava seu estar no mundo.

\footnotetext{
${ }^{83} \mathrm{Na}$ obra de Semprún, a dificuldade de representar a memória da dor ocorre porque a dor da memória não o permite. As limitações da representação da catástrofe em Semprún residem em sua negatividade essencial: a materialidade da dor é que proíbe sua figuração abstrata e não o contrário. Ou seja, a proibição da figuração da dor não se torna um preceito estético para a averiguação da verdade dessa dor, sob pena de a exigência de Adorno ser levada à condição de interdição conceitual da expressão possível da dor concreta. Sobre o direito do sobrevivente expressar a dor, Adorno afirma: "El sufrimiento perenne tiene tanto derecho a la expresión como el martirizado a aullar; por eso quizá haya sido falso que después de Auschwitz ya no se podía escribir ningún poema." In ADORNO, Theodor W.. $\quad$ Dialéctica Negativa - La jerga de la autenticidad. Trad. Alfredo Brotons Muñoz. Madrid: Ediciones Akal, 2005, p. 332.
} 
O fato de que estivesse vivo resultava absurdo para aquele que percebia a vida dentro da perspectiva da morte passada. Para o sobrevivente, preso no círculo vicioso das lembranças compulsivas, o esquecimento se the apresentava como uma salvação. Aqui a memória-salvação manifesta-se em seu aspecto de ausência negativa: o esquecimento. O "pesar de la memoria" significa uma memória que pesa de maneira insuportável pela dor que carrega. A memória é um casulo para o sobrevivente. O desejo e a felicidade da escrita, de inscrever um peso sobre a ausência com a presença do signo pressupunha agüentar o peso dessa marca cunhada na alma. Neste momento, a escrita equivale à morte.

Claude fala ao personagem-narrador dessa gravidade da experiência, imprescindível no fazer literário, ausente nele antes de Buchenwald e excessiva agora. A certa altura da leitura intercalada ao diálogo, ela relaciona a escrita literária à ascese pela qual o passado doloroso é assimilado e transformado pelo escritor. Em seguida, Claude chama sua atenção para o fato de ele não ter falado sobre Buchenwald desde que voltara. Claude toca na incapacidade de o personagem-narrador elaborar seu recente passado. Elaboração esta que constitui a necessidade e a liberdade do fazer literário. Entre pausas, o personagem-narrador contempla o céu azul sobre a sepultura de César Vallejo e discorre sobre os domingos no campo de concentração, sobre a relação da radikal Bose de Kant com a liberdade humana de Schelling e suas pretensões literárias com o testemunho que escreveria. Então fala a ela de sua vontade de estruturar seu testemunho em uma forma romanesca que supere o mero testemunho e sua vivência; mostra sua concepção dialética da relação entre ficção e verdade, na qual a mentira fictícia é capaz de extrair a "verdade" da realidade irreal da Shoah através do efeito de verossimilhança; revela a apreciação do estilo de Faulkner, no qual a memória organiza a narrativa; e apresenta as dificuldades para efetivar essa vontade:

"Mi problema, que no es técnico sino moral, es que no consigo, por medio de la escritura, penetrar en el presente del campo, narrarlo en presente...Como si existiera una prohibición de la figuración en presente... De este modo, en todos mis borradores la cosa empieza antes, o después, o alrededor, pero nunca empieza dentro del campo. Y cuando por fin he conseguido llegar al interior, cuando estoy dentro, la 
escritura se bloquea... Me alcanza la angustia, vuelvo a sumirme en el vacío, abandono... Para volver a empezar de otro modo, en otro lugar, de forma distinta... Y el mismo proceso vuelve a repetirse..." (p. 182)

Por um lado, a recorrência neste romance do presente verbal para narrar o passado é consoante à atualização constante deste passado e decorre de sua dramaticidade na vida do personagem-narrador. O encurtamento da distância estética é-lhe favorável. ${ }^{84}$ Por outro lado, a dificuldade de narrar o campo em presente, enunciada pelo personagem-narrador em situação narrativa, remete ao bloqueio traumático de reviver os acontecimentos de Buchenwald em uma atitude de envolvimento emocional que o presente invoca. Nesse sentido, o fato de o tempo ficcional desse romance não englobar o tempo da rotina do campo propriamente dita, senão através de incursões fragmentadas, parece adequar-se a esse impedimento psicológico. Se a forma espiralada do romance e seu perspectivismo são explicados pelo narrador como uma intenção estética - a inspiração do jazz e da escrita de Faulkner -, ela também representa de maneira adequada a presença de um embaraço involuntário da testemunha. ${ }^{85}$

\footnotetext{
${ }^{84}$ A respeito do procedimento do encurtamento da distância estética em Kafka, Adorno afirma que "Por meio de choques ele destrói no leitor a tranqüilidade contemplativa diante da coisa lida. Seus romances, se é que de fato eles ainda cabem nesse conceito, são a resposta antecipada a uma constituição do mundo na qual a atitude contemplativa tornou-se um sarcasmo sangrento, porque a permanente ameaça da catástrofe não permite mais a observação imparcial, e nem mesmo a imitação estética dessa situação." Mais adiante, o autor explica que "na produção mais avançada, que não permanece estranha a essa fraqueza, [a de um estado de consciência que não tem fôlego suficiente para tolerar sua própria representação estética] a abolição da distância é um mandamento da própria forma, um dos meios mais eficazes para atravessar o contexto do primeiro plano e expressar o que lhe é subjacente, a negatividade do positivo." IN ADORNO, Theodor W.. "Posição do narrador no romance contemporâneo" in Notas de literatura I. SP: Editora 34, 2003, p. 61-62.

${ }^{85}$ Karsten Garscha faz notar que, ao contrário de outras obras anteriores baseadas na experiência de Buchenwald como El largo viaje, El desvanecimiento, Aquel domingo e La escritura o la vida, Semprún consegue alcançar em Viviré con su nombre, morirá con el mío a liberdade de "recordar los terribles acontecimientos y vivencias en el campo mismo, recordar la experiencia no sólo de la muerte de innumerables compañeros de cautiverio, sino también la macabra experiencia de la propia muerte." De acordo com a autora, o maior distanciamento temporal e psicológico com relação ao acontecimento possibilitou ao escritor testemunha a superação e o apaziguamento desse passado terrível em sua consciência e memória. Discordamos de seu exame sobre a evolução de tais textos, pois nos parece que também este último romance assemelha-se aos demais no que concerne aos rodeios para tratar do cotidiano atroz de Buchenwald. A fragmentação como modo "indireto" de representação, técnica que dispersa a narração e descrição da situação extrema do campo, faz-se presente em todas as obras do ciclo de Buchenwald como uma marca da escritura testemunhal deste autor. In GARSCHA, Karsten. "Del cambio de nombre y de muerte: Sobre Le mort qu'il faut de Jorge Semprún" in PAATZ, Annette (ed. and preface) POHL, Burkhard (ed. and preface) BERGENTHAL, Kathrin (epilogue) Texto social: Estudios pragmáticos sobre literatura y cine: Homenaje a Manfred Engelbert. Berlin, Germany: Tranvía--Frey, 2003, p. 280.
} 
O diálogo com Claude problematiza como os procedimentos literários requerem uma atitude psicológica do escritor para lidar com a memória que implica, no caso da literatura de testemunho, esbarrar no terreno do trauma e da cripta em que este se aloja. La escritura o la vida representa a interferência do trauma na forma de representar o horror ao objetivá-lo enquanto alternância de planos temporais e fragmentação narrativa. O tempo do campo de concentração, apesar de ser sentido como um passado que não passa, não se torna passível, contudo, de ser tratado em presente continuamente. O presente verbal e o jogo entre o tempo do mundo narrado e o do comentário do mundo problematizam a tensão entre o domínio do narrador testemunha sobre sua narrativa e as barreiras psicológicas enfrentadas por ele.

O final do fragmento coloca a dialética da escrita e da vida/morte:

"_Ese es sin duda su camino de escritor - susurra -. Su ascesis: escribir hasta acabar con toda esta muerte... (...) ¡ iA menos que sea ella la que acabe conmigo! No es sólo una frase, lo ha comprendido." (p. 183)

Claude pensa que o eu da escrita transforma o passado traumático em uma experiência a seu favor. O personagem-narrador alerta que nesse processo de elaboração e de ascese o eu corre o perigo de sucumbir à força destruidora do conflito traumático. Trata-se de uma fase em que seu eu não tinha forças para transformar a vivência em experiência. Trata-se de uma escrita vital e mortífera em cuja fronteira tênue os pólos opostos dilaceram o eu do sobrevivente.

O nono e o décimo fragmentos trazem a questão de Wittgenstein como contraponto filosófico para pensar o Holocausto. Claude pergunta-lhe se ele se lembra de Wittgenstein, filósofo sobre o qual conversavam antes de Buchenwald. Mas o personagem-narrador, esgotado, "pensaba en César Vallejo". A evocação em silêncio da poesia de César Vallejo durante o diálogo e as digressões do narrador sobre o papel da poesia em sua vida interpõem-se à pergunta de Claude. O narrador envereda por Heidegger, Levinas, Santo Agostinho, Paul-Louis Landsberg e sua esposa. O circuito de sua memória reconstitui o ambiente cultural e intelectual em que foi educado e os temores do grupo da revista Esprit, ligado ao seu pai, quanto ao avanço das políticas autoritárias e totalitárias na década de 
1930 na Europa. Expressões como "ya no recuerdo bien", "sólo me acuerdo", "conservo el recuerdo", "una imagen inolvidable" revelam a relação dessas políticas violentas de Estado com o esquecimento. A narrativa representa como a memória coletiva determina a dinâmica seletiva da memória individual que atende à economia do desejo e da necessidade de sobrevivência. É nesse sentido que a lembrança da esposa de Landsberg é retida pelo personagem-narrador como uma "imagen inolvidable" de sua adolescência.

A lembrança de Wittgenstein remonta à história da perda do caderno de anotações do personagem-narrador. Antes de Buchenwald, ele ensaiava reflexões sobre suas leituras filosóficas e literárias. Os comentários sobre o Tractatus de Wittgenstein constavam desse diário que se perdera com um de seus colegas, Jean Gosset ou Jean Cavaillès, graças ao empréstimo que Claude fizera do caderno a um deles. Segundo o narrador, podia ser um ou outro, pois, além de ambos terem pertencido ao círculo de Claude, o primeiro morrera em um campo de concentração nazista e o segundo havia sido fuzilado. As críticas à sentença de Wittgenstein sobre a experiência da morte são intercaladas à narração do desaparecimento do diário. As histórias intercaladas revelam como o desaparecimento de vítimas dos Estados europeus em nossa época torna insignificante o desaparecimento de seus registros filosóficos. A narrativa joga uma sombra a Wittgenstein, sobrepondo-lhe as histórias de desaparecimentos. É como se o filósofo desaparecesse sob os desaparecimentos, como se ele devesse ser esquecido por perdas que devessem ser lembradas em seu lugar. As histórias assim corroboram a crítica à sentença de Wittgenstein que para o narrador representava "una evidencia de una pobreza espiritual extrema." (p. 188) A fórmula de Wittgeinstein "No se puede vivir la muerte" opõe-se à de "a vivência da morte como essência da experiência". O modo de narrar contesta a sentença lógico-formal do filósofo alemão ao apresentar as histórias desses genocídios como perdas humanas que a perda da escrita (do caderno) registra. Vivenciar a 
morte do outro é nesse caso perder algo "com a perda do outro". A conservação da memória na escrita submete-se à conservação da vida humana. ${ }^{86}$

Toda a querela filosófica que o narrador trava com Wittgenstein refere-se à sua sentença lógica formal pela qual a morte contradiz de modo inconciliável aquilo que pode ser vivido. Para esta testemunha, a vida não é a única forma de existência e o Lager mostra que pode haver outra forma diferente daquela que o senso comum e a lógica formal concebem, uma forma de existência que nega a vida através da inclusão dominante da morte nela. ${ }^{87} \mathrm{Em}$ La escritura o la vida, a relação dialética negativa entre vida e morte fundamenta a experiência do campo de concentração: a aniquilação da vida transforma-se no campo na vivência da morte. ${ }^{88}$

Com o mote de responder à pergunta de Claude, o narrador remonta ao último dia em Buchenwald quando se lembrou do filósofo. A narração do último dia no campo estende-se do décimo primeiro ao décimo sexto fragmento, com alguns desvios episódicos associados aparentemente às lembranças desse dia. $\mathrm{O}$ último

\footnotetext{
${ }^{86}$ Sabemos da intenção dos nazistas de eliminar qualquer vestígio que pudesse dar provas do crime bárbaro cometido nos campos de concentração. Julio Cortázar escreve um pequeno texto, em 1981, cujo tema principal é a barbárie da ditadura argentina. Em ato de denúncia, esse texto, ironicamente, cria uma analogia entre os crimes por tortura, os desaparecimentos e o terror perpetrados nos anos de ditadura na América Latina, particularmente na Argentina, e a presença diabólica de "um elemento infra-humano, de uma força que parece vir das profundidades, dos abismos em que a imaginação inevitavelmente acaba situando todos aqueles que desapareceram." Em dado momento, Cortázar chega a afirmar que essa forma de desaparecimento que suspende a certeza da volta do desaparecido para os que o esperam, em que a "ausência continua existindo como presença abstrata, como a obstinada negação da ausência final", corresponde a um "círculo [que] estava faltando no inferno dantesco". O desaparecimento massivo e silencioso é um importante ponto de intersecção entre a Shoah e a violência institucional organizada no terceiro mundo e representada na literatura de testemunho. Esta forma de crime de Estado não se presta a reclamações legais e institucionais porque oferece um paradoxo incontornável, o de ter que apelar ao próprio criminoso, o Estado moderno, o crime por ele cometido. In CORTÁZAR, Julio. "Negação do esquecimento" in SAÚL, Sosnowski (org.). Obra crítica 3. Trad. Paulina Wacht e Ari Roitman. Rio de Janeiro: Civilização Brasileira, 2001, p. 291-294. ${ }^{87}$ Adorno reflete da seguinte maneira sobre a morte nos campos de concentração nazistas: "Auschwitz confirma el filosofema de la identidad pura como la muerte. El dictum más audaz de Final de partida de Beckett, el de que ya no quedaría mucho que temer, es la reacción a una praxis que en los campos dio su primera prueba y en cuyo concepto, otrora honorable, ya acecha teleológicamente la aniquilación de lo noidéntico. La negatividad absoluta es previsible, ya no sorprende a nadie." Podemos notar como a dialética do idêntico e do não-idêntico, que conduz a reflexão de Adorno, assemelha-se à visão de Semprún. In ADORNO, Th. W.. Dialéctica Negativa- La jerga de la autenticidad. Trad. Alfredo Brotons Muñoz. Madrid: Ediciones Akal, 2005, p. 332.

88 Essa idéia não dista muito da "vida nua" de Agamben, a vida não qualificável politicamente, essencialmente biológica que se submete à manipulação política e ao desideratum do Estado de exceção que a inclui na forma de exclusão.
} 
dia está marcado pela morte de Morales. A história da morte desse companheiro funciona como contraponto exemplar à sentença de Wittgenstein.

Com o pretexto de recuperar a data do último dia em Buchenwald, o narrador relembra a situação de espera dos ex-prisioneiros espanhóis após a libertação do campo para repatriarem-se e questiona sua condição de repatriado. A narração episódica, contudo, expressa o sentido da perda, do esquecimento. Após a libertação, a sensação dos ex-prisioneiros políticos espanhóis em Buchenwald era de incerteza. Com o ditador Franco no poder, estes combatentes antifascistas não poderiam ser repatriados à Espanha. Sua participação na Resistência francesa concedia-Ihes o direito de permanecer na França. A data do translado ao lugar onde tramitariam os papéis assinala um período descrito como confuso, o que explica sua dificuldade para precisar o último dia em Buchenwald. O mundo de pós-guerra estendia o período de extrema insegurança em Buchenwald. Os governos ditatoriais representavam uma ameaça permanente aos ex-prisioneiros.

Percorrendo os meandros nebulosos da memória, o narrador procura ordenar as lembranças numa cronologia de acordo com as confluências entre referências pessoais e sócio-históricas. Nesse esforço, ele alude à metáfora platônica da tabula rasa cujas marcas impressas não estariam totalmente apagadas e, portanto, poderiam ser rastreadas. Para recuperar as lembranças, ele diz ser necessário abstrair-se voluntariamente do presente, como se o esquecimento representasse um fundo opaco sob o qual se conservam as recordações. Trata-se do cone invertido bergsoniano. A imagem do filme gravado em câmera lenta que precisa ser revelado também é empregada. Por fim, a imagem de "un tesoro de recuerdos inéditos" disponível quando necessário fecha a gama de metáforas da memória aludidas pelo narrador. Mas é o $1^{\circ}$ de maio que desempenha a função de ponto de partida para a reconstituição cronológica de seu último dia em Buchenwald: o 26 de abril de 1945. Embora seja uma data comemorativa institucional, ela se vincula à lembrança pessoal da "nevasca de Buchenwald". 
A caminho da França, o personagem-narrador passa por Longuyon, campo de repatriação dos espanhóis de Buchenwald, lugar onde o narrador diz ter recuperado sua "identidad de apátrida, a la que jamás (há) renunciado desde entonces, a pesar de las apariencias administrativas y los cargos oficiales". ${ }^{89} \mathrm{O}$ apátrida é em certa medida aquele que esquece a sua pátria ou é esquecido por ela. A perda da pátria pelo refugiado une-se à perda progressiva das lembranças de sua origem e à perda da contribuição da memória individual para a memória coletiva. ${ }^{90}$

Neste movimento narrativo pautado na dialética entre perda e ganho, esquecimento e lembrança, vida e morte, o episódio com o poeta Louis Aragon é central para compreender a passagem para o esquecimento, o abandono do projeto de escrever mediante a camuflagem. O contato com Louis Aragon acontece durante as visitas do personagem-narrador a Boris Taslitzky, um dos poucos amigos do campo com o qual ainda mantinha contato graças à visão comum que tinham da experiência. Boris é pintor e Aragon pertence ao seu círculo de amizade. Em seu atelier, enquanto Boris retrata sua experiência em Buchenwald, Aragon faz perguntas ao personagem-narrador que fica calado. Diante do seu silêncio, o poeta faz provocações e pergunta-lhe a razão de seu silêncio.

Com Boris e outros companheiros do campo, o personagem-narrador costumava "recitar los poemas de memoria" e compará-los. Na manhã do último

\footnotetext{
${ }^{89}$ O narrador de Semprún refere-se ao cargo ocupado pelo escritor de ministro da cultura do governo de Felipe González, na Espanha, durante os anos de 1981 a 1983.

${ }^{90}$ Ao analisar a tensão entre a memória individual e a coletiva nos escritos de autores exilados e refugiados nos contextos das ditaduras no século XX, Enric Bou aponta que a memória dos exilados costuma apresentar uma fratura problemática. Segundo Bou, a conexão entre a memória coletiva e a individual, condição necessária para que a memória individual encontre um alicerce para manifestar-se, encontra-se rompida na condição de exílio. O autor afirma que os escritores exilados, dentro ou fora de seu país (no caso de Semprún, ele se torna exilado dentro de seu país quando atua clandestinamente contra o regime franquista), encontram dificuldades para validar sua história frente a versão oficial dos fatos. Toda a tentativa destas narrativas é a de mostrar que a memória pessoal dos fatos e sua representação deveriam possuir legitimamente um espaço de ressonância na fabricação da memória coletiva. Conforme Bou, o sentimento de exclusão e a falta de informações e de contato com sua cultura prejudicam a elaboração memorialística desses escritores, refletindo em sua representação um processo memorialista frustrado e uma tensão entre história externa e interna. Enric Bou analisa Autobiografia de Federico Sánchez de Jorge Semprún sob tal perspectiva, considerando-a umas memórias romanescas que apresentam "memorias dobles", ou seja, o desdobramento de Jorge Semprún em escritor e intelectual e em militante do PCE, como procedimento que visa a solucionar esta contradição da obra. In BOU, Enric. "Construcción autobiográfica y exilio: Entre la memoria individual y la colectiva" in Revista Canadiense de Estudios Hispánicos, n. 30, v. 1, Fall 2005, p. 17-32.
} 
dia no campo surge uma disputa lúdica entre Boris e ele pela qual o primeiro defendia a superioridade da poesia de Aragon frente a Char, objeto de fruição recente do personagem-narrador. No verão de regresso, os encontros com Boris Tastitzky já anunciam um período em que a felicidade de recitar poemas vai perdendo lugar no espírito do personagem-narrador, que "ya había iniciado la cura de silencio y de amnesia concertada que se volvería radical unos meses más tarde en Ascona, en el Tesino, el día que (abandono) el libro que estaba intentando escribir." (p. 197) O esquecimento de Buchenwald é plasmado como tratamento de cura e o abandono do projeto de escrita como remédio para o tratamento. O papel em branco necessário para a escrita das memórias de Buchenwald transforma-se na vendagem que cobre a memória-ferida. $\mathrm{O}$ branco pode representar a não-escrita, o silêncio e o esquecimento que opõem-se de modo contraditório à escrita, ao discurso e à memória na representação do horror. A epígrafe de Maurice Blanchot no romance corrobora nossa interpretação. ${ }^{91}$

Antes de tratar das conversas com Aragon no atelier de Boris, o narrador interpõe uma crítica ao estilo realista pictórico de Boris para representar o campo de concentração. A crítica é mais significativa se cotejada com a justificativa que o personagem-narrador dá a Aragon por estar silencioso e com o poema que o poeta escreve baseado nas conversas com Taslitzky e com ele no atelier. $O$ narrador designa o realismo de Taslitzky "atroz" e pensa que sua finalidade era a "de exorcizar las imágenes que le obsesionaban." (p. 198) A representação de Taslitzky é entendida pelo narrador como um modo de esquecimento, de expurgar a memória-demônio, as imagens obsessivas. Segundo o narrador, a tela produzia um efeito contrário de descrédito e inverossimilhança, ou seja, um distanciamento inadequado do receptor justamente pela proximidade mimética entre realidade do campo e representação. Para o narrador, às telas de Boris "carecía brutalmente una tradición referencial de mitos o de alegorías históricas que habrían facilitado su representación" (p. 198) e seu tratamento realista "traiciona esta realidad, ésta le resulta esencialmente reacia." (p. 198) O narrador pensa que o excesso de

\footnotetext{
91 "Quien pretenda recordar ha de entregarse al olvido, a ese peligro que es el olvido absoluto y a ese hermoso azar en el que se transforma entonces el recuerdo." Maurice Blanchot.
} 
realismo do Lager não é comunicado fielmente por um modo realista de representação. Segundo ele, o tratamento realista dado ao ultra-realismo do Lager transmitiria sua aparente verdade, sua falsidade e, ao contrário, a ficção, as mentiras aparentes criadas pela imaginação artística se aproximariam da comunicação de sua "verdadeira" essência.

A justificativa que o personagem-narrador dá de seu silêncio a Aragon incide nessa concepção ligando-a à questão da memória: "Le dije que intentaba escribir, que prefería no hablar demasiado, para conservar el frescor de la escritura, evitando las rutinas y las trampas de los relatos que se han repetido demasiadas veces." (p. 199) O personagem-narrador fala aqui da memória trivial que reproduz as impressões superficiais do cotidiano. A repetição, nesse caso, é desvalorizada por assemelhar-se à memória-papagaio de Valèry. ${ }^{92} \mathrm{O}$ mero testemunho é denegado pelo personagem-narrador por decorrer de uma memória que se atém aos feitos reais, porém aparentes, da rotina repetitiva concentracionária. Nesta perspectiva, tal tipo de memória, repetitiva, obsessiva, não é capaz de "repetir" em outro plano a essência da experiência. O silêncio alegado pelo personagem-narrador, nesse caso, alia-se a uma poética do esquecimento como método de interiorização do próprio e singular. Desse tipo de esquecimento extrai-se o aspecto poético ou a verdade oculta das coisas presentes no indivíduo que as experimentou.

Mas segundo o narrador não é esse tipo de esquecimento favorável à representação do campo que o faz emudecer diante de Aragon. A impossibilidade de dedicar-se a um exercício poético do esquecimento é evidenciada no poema de Aragon que a pressente nas desculpas do personagem-narrador. ${ }^{93} \mathrm{O}$ ato poético

\footnotetext{
${ }^{92}$ O termo memória papagaio é tomado de empréstimo da análise que Harald Weinrich faz da crítica embutida na prática poética proposta por Valèry no tocante à dimensão da memória. In WEINRICH, Harald. "Lembrança sombria e esquecimento abissal, com um aviso contra papagaios (Mallarmé, Valéry)" in Lete Arte e crítica do esquecimento. Trad.: Lya Luft. Rio de Janeiro: Civilização Brasileira, 2001, p. 195-207.

${ }^{93}$ Chanson pour oublier Dachau

Nul ne réveillera cette nuit les dormeurs

Il n'y aura pas à courir les pieds nus dans la neige

Il ne faudra pas se tenir les poings sur les hanches jusqu'au matin

Ni marquer le pas le genou plié devant un gymnasiarque dément

Les femmes de quatre-vingt-trois ans les cardiaques ceux qui justement
} 
de Aragon evidencia o caráter do rastro camuflado. Ele recolhe do silêncio do sobrevivente do universo concentracionário, como de restos, os motivos dessa forma de esquecimento. Ele fabrica seu poema com a seguinte matéria: a necessidade de esquecer disfarçada de necessidade de ocultar para lembrar. A mentira do sobrevivente a Aragon representa sua tentativa de camuflar-se sob esse falso esquecimento que precisa tornar-se verdadeiro para salvá-lo; representa o esquecimento como dupla fraude: ele finge que esquece para assumir a lembrança do campo ao mundo, quando na verdade se escamoteia nesse fingimento para negá-la a si como meio de integrar-se no mundo e seguir vivendo. Ou seja, se o esquecimento é um modo de fingir o que não é, um não

Ont la fièvre ou des douleurs articulaires ou

Je ne sais pas moi les tuberculeux

N'écouteront pas les pas dans l'ombre qui s'approchent

Regardant leurs doigts déjà qui s'en vont em fumée

Nul ne réveillera cette nuit les dormeurs

Ton corps n'est plus le chien qui rôde et qui ramasse Dans l'ordure ce qui peut lui faire un repas

Ton corps n'est plus le chien qui saute sous le fouet

Ton corps n'est plus cette dérive aux eaux d'Europe Ton corps n'est plus cette stagnation cette rancoeur Ton corps n'est plus la promiscuité des autres

N'est plus as propre puanteur

Homme ou femme tu dors dans des linges lavés

Ton corps

Quand tes yeux sont fermés quelles sont les images

Qui repassent au fond de leur obscur écrin

Quelle chasse est ouverte et quel monstre marin

Fuit devant les harpons d'un souvenir sauvage

Quand tes yeux sont fermés revois-tu revoit-on

Mourir aurait été si doux à l'instant même

Dans l'épouvante où l'équilibre est stratagème

Le cadavre debout dans l'ombre du wagon

Quand tes yeux sont fermés quel charançon les ronge

Quand tes yeux sont fermés les loups font-ils le beau

Quand tes yeux sont fermés ainsi que des tombeaux

Sur des morts sans suaire en l'absence des songes

Louis de Aragon

Os versos em itálico nossos correspondem aos evocados pelo narrador na obra. Não transcrevemos todo o poema de Aragon. In ARAGON, Louis. Nouveau Crève-Coeur. 23ª édition, Paris: Gallimard, 1949, p.8284. 
sobrevivente, ele finge que não finge. O esquecimento torna-se o fingidor do fingimento, a negação da negação.

O narrador afirma que esse poema de Aragon ecoou em sua memória em momentos significativos de sua vida dos quais destaca uma noite, numa sala de festas, em Paris, à mesa, diante de uma jovem alemã que lhe deixa a forte impressão de suavidade e inocência. Em contraste com essa suave jovem inocência, a lembrança do poema lhe trazia a velha impressão traumática de a vida presente parecer um sonho em face da realidade passada de Buchenwald. A contradição nessa evocação reside no fato de a suave inocência da jovem alemã manifestar a pesada culpa de viver ignorando Buchenwald com uma falsa inocência. A aparência de que a vida era um suave sonho resulta aqui da perda de qualquer possibilidade de inocência para o personagem-narrador, decorre da pesada memória de Buchenwald. O esquecimento assume o caráter de falsa inocência. A suave inocência da jovem torna-se insustentável para ele por ausentar-se num sonho de esquecimento. Neste período, a memória-dever convoca-o a lembrar, a testemunhar e a fazer lembrar para que Auschwitz não se repita. O imperativo categórico de Kant, transformado na concepção de Adorno ${ }^{94}$, apresenta-se nessa fase como uma dor de consciência que atormenta o sobrevivente:

\begin{abstract}
"Despertando de este sueño que era la vida, por una vez me sentía culpable de haber deliberadamente olvidado la muerte. De haber querido olvidarla, de haberlo conseguido. ¿Tenía yo derecho a vivir en el olvido? ¿A vivir gracias a este olvido, a expensas suyas? Los ojos azules, la mirada inocente de la joven alemana hacían que este olvido me resultara insoportable. No sólo el mío: el olvido general, masivo, histórico, de toda esta muerte antigua." (p. 201)
\end{abstract}

\footnotetext{
${ }^{94}$ Adorno refere-se ao imperativo de Kant para sublinhar sua invalidez a respeito da nova ordem que Auschwitz impõe ao indivíduo na sua relação ética com o social, que vai além do ético e do social: "Hitler ha impuesto a los hombres en estado de no-libertad un nuevo imperativo categórico: orientar su pensamiento y su acción de tal modo que Auschwitz no se repita, que no ocurra nada parecido. Este imperativo es tan reacio a su fundamentación como otrora el dato kantiano. Tratarlo discursivamente sería un crimen: en él puede sentirse corporalmente el momento de lo adicional en lo ético. Corporalmente porque es el aborrecimiento, hecho práctico, del inaguantable dolor físico a lo que están expuestos los individuos incluso después de que la individualidad, en cuanto forma espiritual de la reflexión, está a punto de desaparecer." É necessário ater-se à negatividade deste novo imperativo ético sobreposto, ironicamente, à positividade do kantiano que ergue ao universal a capacidade reflexiva da razão humana. Neste irônico imperativo ético, o que se impõe enquanto negação da elevação do espiritual é o físico sob a face da dor e da desintegração do individual. In ADORNO, Theodor W.. $\quad$ Dialéctica Negativa - La jerga de la autenticidad. Trad. Alfredo Brotons Muñoz. Madrid: Ediciones Akal, 2005, p. 334-335.
} 
A memória-dever opõe-se nesta fase da espiral ao esquecimento-culpa e à vida-sonho. ${ }^{95}$

Embora a poesia de Aragon sofra considerações negativas do narrador e a ressalva de que "la expreriencia de la deportación (es) inasible no obstante desde fuera", ele observa os acertos de sua representação poética. O narrador rememora as vezes que recitou o poema e se serviu de sua memorização para tentar rever aqueles anos "de morte" e expressar sua simultânea impossibilidade de revisão definitiva. A visita a Buchenwald em 1992 é mencionada como uma dessas ocasiões que revelaram a necessidade de reescrita permanente da experiência, seu trabalho interminável de luto. A rememoração e a reescrita permanente supõem a própria impossibilidade de cicatrizar a ferida definitivamente, não obstante a reelaboração do passado através da escrita transformar a relação do sobrevivente com seu passado e com o mundo presente.

Os fragmentos quinze e dezesseis narram a morte de Morales. O episódio começa com a frase dita por Morales no leito da enfermaria de Buchenwald: "_ No hay derecho... - susurra Morales, vuelto hacia mí. La sábana blanca cubre su cuerpo como un sudario en el camastro del Revier sobre el que yace." (p. 203204) A indignação de Morales em face de sua morte indigna, após uma história de luta e resistência na Guerra Civil Espanhola e na França, reverbera o questionamento do personagem-narrador quanto à dignidade de seu esquecimento, representada no fragmento anterior. A imagem dos lençóis brancos que cobrem o corpo de Morales soma-se à série de imagens do branco que neste capítulo do romance compõe a dialética entre lembrança e esquecimento da morte em Buchenwald. O branco do lençol de Morales alinha-se à imagem da neve sobre o Ettersberg. Wittgenstein entra no fragmento como não-lembrança. $O$ narrador remonta a momentos antes de ser chamado para junto de Morales, a pedido do amigo, e comenta que "Todavía no (se) había acordado de Wittgenstein." (p. 204) A não-lembrança do filósofo é um esquecimento que não

\footnotetext{
${ }^{95}$ Nessa fase da vida do personagem-narrador, a proibição de consolo e a proibição de esquecimento de Adorno com relação à catástrofe de Auschwitz tornam-se para ele o esquecimento inconsolável.
} 
decorre da tentativa de lembrar, não corresponde à perda de algo que se buscava. Ao contrário, Morales significa uma perda inesquecível ao sobrevivente.

A narrativa nos oferece um sumário da vida de Morales em que destacamos a ação heróica do companheiro, tanto em Buchenwald quanto nas batalhas de que participou, associada a dois aspectos: a influência da leitura de o Manifesto comunista de Karl Marx e $O$ vermelho e o negro de Stendhal nos rumos de sua vida e o seu talento de narrador do qual o personagem-narrador costumava desfrutar. Em memória de Morales, o narrador descreve a memória de leitor e narrador de Morales. O companheiro falava, com "una emoción existencial", da transformação que as leituras tinham acarretado em sua visão de mundo e em seu agir nele. A relação de Morales com a leitura está marcada por processos de despertar de consciência, identificação e iniciação. Leitura e vida imbricam-se na narração da história de Morales de modo que a memória de suas ações não pode prescindir da memória de suas leituras, sob pena de se tornarem ações ocas, sem sentido. O narrador enxerga na vida de Morales uma história "de lo más novelesco" e em Morales, um narrador às antigas, que tinha a velha aura da narrativa tradicional. Conforme nosso narrador, essa dupla sobrevivência de Morales, enquanto herói e narrador de suas proezas, não faz jus à sua morte estúpida e ignominiosa no campo. Morales morre de disenteria após ter escapado de uma série de provas e perigos.

O personagem-narrador tentara acompanhar a morte do companheiro com um poema de César Vallejo sobre a Guerra Civil Espanhola, mas, à diferença de M. Halbwachs que ao ouvir os versos de Baudelaire recuperara em seu olhar "un orgullo terrible", Morales não teve tempo de ouvir a recitação:

\footnotetext{
"Su mirada expresa el desamparo más abominable. Unas lágrimas fluyen por su máscara de guerrero.

_Qué vergüenza - dice con el último aliento.

¿Oigo acaso ese susurro? ¿Acaso adivino sobre sus labios las palabras que expresan su vergüenza?

Se le ponen los ojos en blanco: ha muerto." (p. 209)
}

A recitação do poema épico "España, aparte de mí este cáliz" a Morales consiste num gesto fraterno para restituir a dignidade à sua morte vergonhosa. $\mathrm{A}$ memória lírica restauraria a perda da dignidade da vida no momento da morte. 
Enfim, trata-se de um discurso fraterno contra o Mal do campo, que outras formas discursivas não contemplam. ${ }^{96} \mathrm{~A}$ narração da impossibilidade do último gesto discursivo de fraternidade na "vivência da morte" de Morales ganha mais força ao expressar a indignação contra o pensamento lógico formal de Wittgenstein:

"La muerte no es un acontecimiento de la vida. La muerte no puede ser vivida', había escrito ese cabronazo de Wittgenstein. Yo había vivido la muerte de Morales, no obstante, la estaba viviendo. Como, un año antes, había vivido la muerte de Halbwachs. (...)" (p. 209)

Num último gesto fraterno, o personagem-narrador fecha os olhos do amigo. Esse gesto é descrito como natural e proveniente do "fondo de la más antigua sabiduría. Del más remoto conocimiento." (p. 209) A memória-sabedoria, coletiva e social, acompanha o gesto fraterno pessoal e sócio-cultural do personagem-narrador. ${ }^{97} \mathrm{O}$ último gesto do episódio incide no respeito à ausência do morto: ao fechar seus olhos, a morte faz-se presente pela ausência do olhar. Aqui, a recorrente imagem dos olhos abertos para a morte como indício do Mal radical significa uma ausência presente e não uma presença ausente. Com os olhos abertos, o horror da ausência do vivo faz-se mais presente por faltarem cerimônias sócio-culturais em sua memória. A morte ultrajante no campo não pode ser enlutada porque não se transformou em memória cultural. Ao contrário, continua obcecando os vivos com uma estranha e inquietante presença. Essa é uma faceta do Mal dos campos ligada à dialética da falta e da presença, do

\footnotetext{
${ }^{96}$ No prólogo de Semprún ao livro Seguir viviendo, de Ruth Klüger, um testemunho literário da comunidade judia de Viena durante o nazismo, o escritor espanhol repisa a importância do papel da poesia na sobrevivência aos campos de concentração. Este não é um momento textual isolado. Karsten Garscha, entre outros críticos de sua obra, afirma a divergência entre Semprún e Adorno quanto à negatividade da poesia e da cultura para lutar contra a barbárie na modernidade, antes, durante ou depois de Auschwitz. Neste prólogo, Semprún menciona a passagem de Si esto es un hombre, de Primo Levi, na qual as estrofes de La divina comedia, de Dante, recitadas de memória por Levi a um companheiro de campo numa manhã fria em Auchwitz, ajudam-no a superar o cansaço e o fazem resgatar um sentimento de pertença à humanidade. Semprún ainda afirma neste prólogo que não importava o conteúdo da poesia, mas sim a forma, pois a mera forma poética, com seus ritmos e métrica, colaborava para a sua memorização, para recuperar o tempo da vida subtraído pela rotina mortífera do campo. In SEMPRÚN, Jorge. (prólogo) in KLÜGER, Ruth. Seguir Viviendo. Barcelona: Círculo de Lectores, Galaxia Gutenberg, 1997, p. 5-8.

${ }^{97}$ Em certa medida, a concepção de memória teorizada por seu professor Maurice Halbwachs permeia a narração do episódio sobre Morales. Baseamo-nos no estudo de Ecléa Bosi. In BOSI, Ecléa. "MemóriaSonho e Memória-Trabalho", "Halbwachs, ou a reconstrução do passado" in Memória e Sociedade: lembranças de velhos. São Paulo: T. A. Queiroz, Biblioteca de Letras e Ciências Humanas, v. 1, 1979, p. 1522.
} 
silêncio e da diç̧ão, da lembrança e do esquecimento, representada por Semprún.

A cena da leitura da carta de Claude encerra o capítulo. Claude lê uma citação de Keats analisada na carta. Os versos de Keats reportam à calamidade presente no olhar como uma lembrança apavorante: "There was a listening fear in her regard. As if calamity had but begun." (p. 210) O comentário de Claude insiste na capacidade de a escrita do poeta fazer uma "transposición serena de una experiencia que fue atroz, sin duda, pero que está ahora superada..." (p. 210) As palavras de Claude analisam a transformação da falta em presença através da elaboração escrita. De acordo com seu discurso, a elaboração do passado leva à superação da experiência e constitui uma etapa necessária da atividade estética. Assim, Claude vincula o autoconhecimento à consciência estética e à consciência crítica e ideológica do escritor no mundo. A essa convocação de Claude, o personagem-narrador responde com o silêncio, com a falta de palavras contendo a falta de energia de vida: "Pero no tengo ganas de hablar. Estoy agotado, vaciado de toda palabra posible." (p. 210)

O personagem-narrador não volta a ver Claude após esse dia em função do esquecimento de Buchenwald e do abandono da escrita. As ausências somam-se e interpenetram-se: a ausência das lembranças de Buchenwald, a de Claude e a das inscrições na folha em branco. O produto final destas ausências é a ausência de si no eu, a transformação da identidade: "Me había convertido en otro, para seguir con vida." (p. 211) O poder da vida para ele neste momento implica a perda do poder da escrita, sendo a escrita uma outra forma de vida.

As lembranças de Buchenwald reaparecem no final do capítulo como uma memória-câncer cuja cura exigia o esquecimento ${ }^{98}$ : "Cual cáncer luminoso, el relato que me arrancaba de la memoria, trozo a trozo, frase a frase, me devoraba

\footnotetext{
${ }^{98}$ Shoshana Felman relaciona a situação extrema do testemunho à doença, à cura ou à ausência de cura. Para a autora, o testemunho aproxima-se mais de uma prática discursiva que enfatiza o processo clínico de cura dos traumas de dimensão histórica na era contemporânea do que de uma teoria objetiva e conceitualizante capaz de extrair da experiência traumática conhecimentos positivos para a ação humana. Segundo Felman, como forma de mediatizar a ação histórica e o impacto do acontecimento, o testemunho exprime o escândalo de uma doença incurável cujo processo de cura, no entanto, impõe-se como necessidade premente. In FELMAN, Shoshana. "Educação e crise, ou as vicissitudes do ensino" in Pulsional. Revista de Psicanálise. Ano XI e XII, n. 116-117, dezembro 1998/janeiro 1999, p. 9-48.
} 
la vida." (p. 211) A tessitura da escrita é imaginada como um tecido do corpo. Letras são células desse tecido que forma a memória. Sob um estado de melancolia, cuja "tarea de luto (era) inacabada: interminable" (p. 211), a cura e o retorno à vida vêm em forma de esquecimento, do não-idêntico ao eu. A nova sobrevivência implica um outro modo de aniquilação, o apagamento de sua identidade de sobrevivente testemunha escritor. Por outro lado, a amnésia deliberada compreendia uma empresa de antemão fracassada. A perda voluntária das lembranças do campo às vezes não só era traída pelo inconsciente como significava uma traição à memória dos companheiros, à fraternidade que os unia, à consciência de um dever ético. O eu que se traía, traía o outro-universo concentracionário dentro de si. Essa nova identidade vivia à custa de uma camuflagem que oprimia e não permitia a integração da sombra, da morte na vida.

Ao final, o texto insinua essa morte de parte do eu:

“_ ¿Qué poetas leíamos juntos? - preguntó Claude-Edmonde MagnyKeats, por supuesto... Y Coleridge, Rainer Maria Rilke, me acuerdo... (...) _ César Vallejo - le digo -. Le traduje algunos poemas...

_ ¡Vallejo, claro! - dice con voz apagada -. ¡He llevado flores a su tumba regularmente mientras usted ha estado fuera!

¿He regresado realmente?" (p. 212-213)

Para o narrador, viver sob a égide do esquecimento de Buchenwald é estar ainda fora da vida, posto que exige dele a exclusão de sua experiência vital, a da morte. O sepultamento da experiência da morte neste momento comporta uma experiência que sepulta as lembranças da experiência da morte. A metáfora dos versos de César Vallejo, "En suma, no poseo para expresar mi vida, sino mi muerte...", é uma resposta irônica à sentença de Wittgenstein. O nonsense destas palavras, propriedade lingüística do gênero lírico, exprime a irracionalidade da experiência do Mal do campo. Os versos assinalam que, após Buchenwald, a "vivência da morte" transforma-se na experiência da morte enquanto dificuldade de exprimir tal experiência. Esse sentido ambivalente do verso de Vallejo representa a concepção dialética do narrador sobre a experiência. ${ }^{99} \mathrm{O}$

\footnotetext{
${ }^{99}$ Há uma passagem em Aquel domingo, em que o personagem-narrador, Gérard, em um diálogo com o personagem Barizon, companheiro de Buchenwald, expressa essa concepção dialética da realidade do campo: “_ ¿El crematorio también es dialéctico? - dice con tono de guasa (Barizon).

Pero no es una pregunta que desconcierte a Gérard.
} 
sobrevivente só possui a própria morte para expressar sua vida não só porque sua vida é a expressão da morte que ele vivenciou, mas também porque não poder expressar essa morte é como estar morto; significa a transformação dialética do Mal do campo.

A cena da carta de Claude-Edmonde Magny constitui o núcleo do capítulo cujo sentido refere-se à dificuldade de falar por esgotamento. No diálogo entre ambos, o silêncio do personagem-narrador somente é quebrado por uma reflexão intermediada por leituras em comum de filósofos e escritores e por um sumário dos fatos de Buchenwald que poderiam ser descritos e narrados. A poesia de César Vallejo, recordada mas silenciada durante toda a conversa pelo personagem-narrador, cumpre a função de túmulo para sepultar as insuportáveis lembranças de Buchenwald. A escassez das formas discursivas da narração, da reflexão, da digressão, da descrição e da evocação lírica na elocução do personagem-narrador no diálogo representa a dificuldade de rememorar a catástrofe nesse momento. A incerteza de ter regressado, o sentimento de eterno exílio, a convicção de não possuir uma pátria, de não estar em nenhuma parte, acentuam o desamparo, a impossibilidade de luto, de não conseguir despertar para a realidade de fora do campo, que se Ihe apresenta por antinomia como um sonho.

\subsection{O túmulo esquecido}

A ação principal do capítulo "El paraguas de Bakunin" representa a estratégia de camuflagem encontrada pelo personagem-narrador para esquecer as lembranças de Buchenwald. Três meses depois da libertação do campo, o personagem-narrador, instalado em Ascona, na Suíça de língua italiana, junto à

\footnotetext{
Por supuesto - contesta.

A ver, explícamelo - dice Barizon frunciendo el ceño.

- El crematório es la muerte, ¿no? El máximo signo de la muerte. Ahora bien, la muerte no está más allá de la vida, fuera de la vida, después de la vida. La muerte está en la vida, es la vida. Del mismo modo, el crematorio está en el campo. Es mucho más que un símbolo, es la muerte que está en medio de nuestra vida, que es nuestra vida. El crematorio es el signo de la muerte, pero es asimismo el signo de la vida que nos resta por vivir, nuestro probable futuro.” In SEMPRÚN, Jorge. Aquel domingo. Barcelona: Tusquets, 2004, p. 260.
} 
sua família, procura escrever. Numa viagem de trem a Berna, cidade para onde todo mês se deslocava a fim de atualizar seu visto de permanência na Suíça, ele conhece Lorène. $\mathrm{O}$ desconhecimento de Lorène sobre seu passado colabora para que tenham um curto romance. Em sua casa, Lorène guarda o guarda-chuva de Bakunin como um troféu da família aristocrática. Depois de sucessivos convites de Lorène ao personagem-narrador para vê-lo, ele um dia aceita. A história do guarda-chuva sugere-lhe o artifício empregado para pôr em prática sua nova estratégia de sobrevivência.

A personagem Lorène, anunciada no último fragmento do capítulo anterior como aquela que "(lo) salvó - o (lo) perdió”, é construída como uma deusa cujos poderes sobrenaturais consistem no conhecimento da arte de esquecer. ${ }^{100}$ Como Lete ou como Circe, é através do feitiço do amor e do desconhecimento da história do personagem-narrador que Lorène atua como a mestra do esquecimento.

A tensão entre o referencial e o figurado chega a seu paroxismo neste capítulo, pois a história contida no episódio do guarda-chuva de Bakunin possui uma ambigüidade e um caráter simbólico contundentes. A elipse torna-se o recurso de linguagem privilegiado na ação narrativa.

O capítulo inicia com as circunstâncias que antecedem a cena da visita do personagem-narrador à casa de Lorène. À saída do cinema, ela aparece de surpresa para encontrar-se com ele. Dois atos de memória roubada sucedem-se neste primeiro fragmento. O personagem-narrador vai ao cinema para assistir a uma adaptação de uma obra de Eugene O’Neil e encontra um reflexo inesperado. Antes da projeção do filme, o diário local projeta imagens fragmentadas de vários campos de concentração, durante a ocupação dos exércitos aliados. Ele fica atordoado e não consegue mais prestar atenção ao filme. Mas antes de narrar a

\footnotetext{
${ }^{100}$ Ao tratar da origem mítica de Lete, Weinrich afirma que entre os gregos "Letes é uma divindade feminina que forma um par contrastante com Mnemosyne, deusa da memória e mãe das musas. Segundo a genealogia e a teogonia, Lete vem da linhagem da Noite (em grego Nyx, Nox em latim)". Quanto a Lete, Weinrich observa que não pode "deixar de mencionar o nome de sua mãe. É a Discórdia (em grego, Eris, em latim, Discórdia) o ponto escuro nesse parentesco." Para o estudioso, porém, a genealogia não corresponde ao fundamental desse mito, "pois 'Lete' (ele ou ela) é sobretudo nome de um rio do submundo, que confere esquecimento às almas dos mortos. Nesse campo de imagens o esquecimento está inteiramente mergulhado no elemento líquido das águas. Há um profundo sentido no simbolismo dessas águas mágicas. Em seu macio fluir desfazem-se os contornos duros da lembrança da realidade, e assim são liquidados." In WEINRICH, Harald. Lete - Arte e crítica do esquecimento. Trad.: Lya Luft. Rio de Janeiro: Civilização Brasileira, 2001, p. 25.
} 
reação do personagem-narrador ante a visão destas imagens, o narrador colocanos à saída do cinema, no momento em que se depara com Lorène esperando-o para convidá-lo para ser espectador de seu tesouro, o guarda-chuva de Bakunin.

A presença de Lorène provoca-lhe uma turbação do coração. Ele nota como o olhar da amante brilha "con una luz alegre y dorada". A mudança de estado de espírito do personagem-narrador ao vê-la soma-se à seqüência de memória roubada representada no capítulo. Ele imediatamente aceita o convite. $O$ narrador considera a aceitação do convite um pretexto qualquer para que estivesse ao lado da amante. De modo que a presença e o convite de Lorène propiciam a interrupção do estado de espírito do personagem-narrador e constituem modos de desviar sua memória e atenção.

$O$ estado em que o personagem-narrador assiste ao filme sobre a obra de O'Neil é descrito nos seguintes termos: "un estado de embotamiento", "aquejado de estupor, traspuesto. Pero carente de inquietud, sin embargo: sumido en la serenidad de la desesperación más suave y algodonosa." (p. 215) A turbação em que o deixa Lorène é de índole diferente, é de uma inquietação alegre.

$\mathrm{Na}$ descrição das imagens transmitidas pelo documentário, a narrativa enfatiza o ponto de vista que apreende e transforma a realidade em imagens virtuais. As expressões "El ojo de la cámara exploraba", "El ojo de la cámara registraba", "El ojo de la cámara captaba", "El ojo de la cámara seguía" indicam a manipulação da câmera por um ponto de vista humano. A câmera é um objeto cujo olho artificial está a serviço das intenções deste olhar humano que a utiliza como mediação com a realidade. A montagem do documentário a partir de imagens recortadas de vários campos de concentração reforça o processo de seleção e construção pelo qual o documentário é produzido. A diferença entre o visto e o vivido, entre as imagens cinematográficas e as imagens da memória pessoal da testemunha aparece como o grande fator de perturbação do personagem-narrador. No discurso do narrador, a "pretensa" objetividade das imagens cinematográficas contrapunha-se às imagens íntimas do sobrevivente. Para ele, tais imagens cinematográficas sobrepunham-se às imagens de suas lembranças subjetivas, roubando-lhe um bem precioso: 
“(...) estas imágenes de mi intimidad se me volvían ajenas, al objetivarse en la pantalla. Se sustraían así a los procesos de memorización y de censura que me eran personales. Dejaban de ser mi bien y mi tormento: riquezas mortíferas de mi vida. Ya tan sólo eran, o por fin eran, la realidad radical, exteriorizada, del Mal: su reflejo glacial y no obstante ardiente." (p. 216-217)

O narrador menciona o efeito de ultra-realismo, de objetivação objetiva da realidade, que registrava o aspecto radical e exterior do Mal de modo que a aparência não apresentesse a essência na construção da "verdade" do Holocausto. As imagens filmadas alterariam, assim, o sentido subjetivo da dialética entre sonho e realidade. $\mathrm{Na}$ impressão do personagem-narrador, suas incertezas decorrentes da proximidade entre memória e imaginação eram eliminadas frente ao choque de veracidade produzido pelas imagens cinematográficas. Essa inversão é ironizada pelo narrador:

"Como si, paradójicamente a primera vista, la dimensión de irrealidad, el contenido de ficción inherente a toda imagen cinematográfica, incluso la más documental, lastraran con un peso de realidad incontestable mis recuerdos más íntimos." (p. 217)

O narrador identifica nesse processo mediático a contradição entre a memória pública e objetiva e a memória privada e subjetiva. Nessa contradição reside a alienação que ele insinua: a testemunha, enquanto indivíduo e sujeito histórico, sente-se despojada de sua memória particular e excluída da versão oficial da memória coletiva. Trata-se de uma dupla alienação: aquilo que outorga veracidade à sua experiência provém de um processo de elaboração alheio que se the impõe como critério de verdade para autenticá-la: "Por un lado, indudablemente, me veía desposeído de ellos; por el otro, veía confirmada su realidad: no había soñado Buchenwald." (p. 217) ${ }^{101}$

À guisa de digressão, o narrador critica os efeitos da representação do documentário. Sem negar a confirmação da "verdad de la experiencia vivida", o narrador destaca a dificuldade de transmiti-la, torná-la comunicável, clara e precisa. O narrador reclama da ausência de técnicas e recursos cinematográficos,

\footnotetext{
${ }^{101}$ Esse efeito perverso de irrealidade, de espectador, quanto ao vivido pelo sobrevivente é comentado por Adorno: "Hombres de reflexión y artistas han dejado en no pocas ocasiones constancia de una sensación de no estar del todo presentes, de no participar en el juego; como si no fueran en absoluto ellos mismos sino una especie de espectadores.” In ADORNO, Theodor W.. Op. cit., p. 333.
} 
de contextualização histórica, de uma organização que the conferisse senso de continuidade e de uma voz que expressasse os sentimentos e as emoções a partir de um locus de enunciação e de um ponto de vista interior, subjetivo: "En resumen, se tendría que haber tratado la realidad documental como una materia de ficción." (p. 218) Nesta situação narrativa, a dialética entre verdade e fiç̧ão desdobra-se na contraposição entre mostrar e ocultar para representar. A contradição que o narrador problematiza é a de que o que é mostrado como se nada ocultasse do real rouba do real sua "verdade", ao passo que a ficção enquanto ocultação do real permite que a "verdade" que se esconde na aparência do real se ofereça.

O documentário furta do personagem-narrador a atenção ao filme, perturbao de tal modo que ele não consegue acompanhar a seqüência das cenas. Já nesse primeiro fragmento, $\mathrm{o}$ narrador apresenta os elementos que poderiam constituir-se em uma impossível e mítica ars oblivionis. ${ }^{102}$ A interrupção de um estado de espírito, de um fluxo mnemônico, desencadeado por qualquer motivo, consiste em um recurso do qual se pode valer para escapar dos tormentos da memória. As lembranças de Buchenwald são tratadas como um ladrão que the rouba a atenção voltada ao presente. Ora, para livrar-se desse gatuno traiçoeiro, o sobrevivente faz um pacto silencioso com outra espécie de ladrão. Em troca de seus tesouros do passado, o novo ladrão lhe concederia a paz do esquecimento, o estar no presente.

O personagem-narrador conheceu Lorène, num vagão de trem, voltando de Berna a Locarno. Enquanto come obsessivamente, ela se aproxima dele e se senta a seu lado. O episódio apresenta formas de interrupção de atos, pensamentos, lembranças, modos de desviar o foco de atenção sobre algo como indícios do método de esquecer. Se um "olvido sistemático" é impossível, talvez

\footnotetext{
${ }^{102}$ Harald Weinrich descreve que em um jogo de salão para inventar disciplinas científicas não existentes por motivos lógicos e epistemológicos, Umberto Eco imagina a criação de uma arte do esquecimento. Essa brincadeira dá origem a uma conferência dada em um congresso (1966) em que Eco serve-se do método semiótico para provar a impossibilidade de existir uma arte do esquecimento. Seu argumento se apóia no fato de que todos os sinais de presença na arte de lembrar não são ausências, portanto o esquecimento só poderia ser provocado por uma perturbação da memória, uma espécie de válvula de segurança para o transbordamento. Weinrich, contudo, empenha-se em investigar as possíveis formas dessa arte na literatura. In WEINRICH, Harald. Op. cit., p. 34.
} 
seja possível barrar o fluxo obsessivo dos pensamentos e das lembranças de Buchenwald. Essa crença e esse aprendizado vão se desenvolvendo no sobrevivente através do seu relacionamento com Lorène. Assim, os comentários do diálogo do primeiro encontro com Lorène assinalam esse método de esquecimento, além de introduzi-lo no leitmotiv do capítulo, o do "paraguas de Bakunin":

“_ ¡Locarno! - había exclamado yo dos días antes -. ¡Entonces debe de conocer a Bakunin!

Pretendía desconcertarla, por supuesto. Provocar su curiosidad, su atención. Su sorpresa encantada, por último, cuando me hubiera visto luciéndome con desenvuelta y burlona erudición a propósito de Bakunin en Locarno.

Fracasé. Lorène había asentido con la cabeza, imperturbable. _ En efecto - respondió, como si fuera lo más natural -. ¡Hasta tenemos su paraguas en casa!

Me quedé con un palmo de narices." (p. 218-219)

Desconcertar, provocar curiosidade, chamar a atenção, surpreender são atos que têm em comum um desvio de estado e de atitude através de uma interrupção do pensamento. A intenção do personagem-narrador de causar admiração a Lorène através de sua erudição é revertida na sua surpresa desapontada em face da naturalidade da resposta da personagem.

Há uma semelhança entre a situação em que Lorène se aproxima do personagem-narrador no vagão e aquela em que ela o encontra à saída do cinema. Em ambas, o personagem-narrador encontra-se num transe obsessivo que é quebrado pela presença da personagem. No vagão, a velha obsessão da fome de Buchenwald atualizava-se enquanto ele comia e bebia até saciar-se:

"Aquel día, sin embargo, había reaparecido la antigua obsesión. Más moral que física, por cierto. Lo que me roía de repente era la idea del hambre, su recuerdo agotador. En un contexto del todo distinto: sabía que podía saciarla. El hambre volvía a ser algo apetitoso." (p. 219)

O "recuerdo agotador" da fome estabelece um antagonismo com a atual intenção e possibilidade de saciá-la. O narrador define a fome do campo como aquela que nunca findava porque era aquela para a qual a comida sempre acabava. A fome insaciável de Buchenwald que esgotava as forças do ser transforma-se agora numa fome que acaba porque é aquela para a qual a comida 
não se esgota jamais. No entanto, a lembrança da fome de outrora é tão insaciável como a vontade de saciar a fome atual; reaparece esgotando as forças de viver do sobrevivente. Lorène retira-o desse estado.

Ao contrário de Claude, Lorène não se incomoda com o laconismo do personagem-narrador. A princípio ignora seu passado, não podendo, portanto, invocá-lo ao sobrevivente. Depois, finge ignorá-lo. Fala de si, do seu passado. $\mathrm{O}$ narrador reproduz o relato da personagem utilizando palavras que se ajustariam ao seu próprio passado se extraíssemos as palavras "matrimonial" e "conyugal": "Lorène acababa de dejar atrás una experiencia matrimonial desastrosa. Seis meses de pesadilla, según decía. Un divorcio costoso acababa de poner punto final al infierno conyugal." (p. 221, o itálico é nosso) A visão de Lorène sobre seu casamento sugere ao sobrevivente "dejar atrás" sua experiência do desastre.

Também os prazeres dos sentidos participam do novo método de esquecimento. A presença da jovem satisfaz os sentidos do personagem-narrador:

"Yo la escuchaba distraídamente, pero la contemplaba con deleite. Sus
gestos graciosos, su voz armoniosa, su comportamiento en la mesa
perfecto, sin afectación. Una delicia para los ojos mientras me deleitaba
con unos alimentos sutiles o consistentes." (p. 221)

A narrativa repete a pergunta do personagem-narrador sobre Bakunin, apresenta a procedência nobre de Lorène e um resumo da história do guardachuva. A história do guarda-chuva de Bakunin é narrada sob o ponto de vista crítico do sujeito da enunciação, que reelabora a história contada por Lorène. Alguns indícios sobre a função que esta história desempenha no romance são anunciados neste resumo. O narrador nos informa que "Olvidado en el vestíbulo de los antepasados de Lorène, el paraguas conservó su anonimato durante un cierto tiempo. Se trataba de un paraguas perdido, sin más. Allí estaba sin suscitar ningún interés ni discordia." (p. 222, o itálico é nosso) O fato de o guarda-chuva ter sido esquecido e de conservar seu anonimato como algo perdido coincide com o destino desejado pelo sobrevivente para suas lembranças de Buchenwald. Há porém um indício que nos pode escapar: Discordia, segundo Harald Weinrich, é o termo em latim relativo a Eris, a mãe de Lete, divindade feminina do esquecimento. A discórdia, para Weinrich o "ponto escuro" do mito de Letes, 
aparece na história quando Bakunin se interessa em reaver seu guarda-chuva e reclama-o. O embate verbal do bisavô de Lorène com Bakunin é narrado nos termos de uma batalha em que os argumentos do velho nobre - defensor do direito à herança, portanto franco inimigo dos ideais de Bakunin -, levam-no à vitória por sua astúcia e fingimento: "Después salió de la residencia de los bisabuelos de Lorène, abandonando allí su paraguas al enemigo, como un estandarte en el campo de batalla." (p. 223) Se a discórdia gera o esquecimento e tem necessidade dele, a astúcia, os pretextos e as escusas falsas são facetas da discórdia, ligando-se também ao esquecimento. Esses são os recursos que facilitam o desenvolvimento de uma arte do esquecimento na poética do testemunho de Jorge Semprún.

O terceiro fragmento, o miolo do capítulo, representa o momento da virada através de uma espécie de reconhecimento. A visão do guarda-chuva de Bakunin coincide com um novo despertar que se opõe ao despertar do capítulo anterior do romance. O personagem-narrador vislumbra na cena do guarda-chuva uma solução para sua angústia e seu dilema aporético entre lembrar e esquecer. A narração enfatiza a súbita significação que o guarda-chuva ganha para o personagem-narrador ao contemplá-lo. Antes, ele concordara em vê-lo como uma estratégia para fugir do entorpecimento diante do documentário dos campos. No percurso à casa de Lorène, ele descobre um indício intrigante: a amante pareciase com a mulher de Paul-Louis Landsberg, uma lembrança de sua adolescência que figurava enigmática por mostrar-se ao mesmo tempo evidente e indecifrável. Esse processo de lembrar mediante o esclarecimento de um ponto obscuro da memória anuncia por analogia antitética o que ocorrerá com o esquecer. Como no lembrar, a visão do guarda-chuva completa algo no esquecer que, por um lado, parece evidente, por outro, difícil de acertar. O personagem-narrador contempla o guarda-chuva num estado de beatitude. Há uma insinuação de que o esquecimento é fruto de uma revelação que mudaria radicalmente sua vida $e$, irônica e contraditoriamente, como o narrador afirma, sua morte também:

“(...) una ilusión violenta empezaba a despuntar.

La vida todavía era vivible. Bastaba con olvidar, con decidirlo firme, brutalmente. La elección era sencilla: la escritura o la vida. ¿lba a 
tener el valor - la crueldad para conmigo mismo - de pagar este precio?" (p. 226)

Silenciar, esquecer e não escrever pertencem à negação de Buchenwald, como um fingimento ou uma ilusão, um truque, que vai crescendo em sua consciência. A metáfora da luz e da sombra complica-se no texto, pois se o esquecimento é convencionalmente colocado ao lado da sombra e da névoa, aqui ele resplandece como um raio de sol súbito que dá ao sobrevivente a ilusão de poder seguir vivendo, de apaziguar a dor da memória.

No quarto fragmento, o tempo do mundo narrado avança quinze dias e trata da descoberta da "oreja mala" do personagem-narrador por Lorène. Na última vez que visitou Claude, ele cai do vagão do trem, desmaia e corta a orelha direita no trilho. A história da orelha cortada numa queda de um trem possui uma dupla significação. Por um lado, reforça a imagem de memória mutilada, de um eu mutilado. O narrador ironiza o motivo da queda, não deixa claro se ocorreu em função de um ato voluntário de suicídio ou se decorreu de uma fraqueza, uma vertigem, pelo estado febril da insônia. "Cansancio", "febrilidad", "vértigo" e "desvanecimiento" são encadeados como motivos que provocam a queda, o desmaio e o ferimento da orelha. É lícito analisar a orelha mutilada como conseqüência de uma dor espiritual que mutila fisicamente. Mas há outro sentido: o episódio aborda a vontade de mutilar essa memória de um eu dilacerado para que esse eu se sinta, paradoxalmente, inteiro. Assim, o esquecimento deste sobrevivente converge com sua queda de um vagão de trem na medida em que esta significa uma ruptura da vida, um esquecimento do acontecimento que implicou uma ruptura, uma divisão de sua vida em antes e depois. A orelha cortada antecipa a necessidade de cortar da memória as lembranças da dor para que essas não efetuem cortes vitais na integridade física do sobrevivente. A orelha cortada aparece como metonímia e metáfora do Mal do campo que deriva em seu esquecimento, apesar de seu valor referencial.

A descoberta por Lorène da "oreja mala" apresenta novos indícios e uma segunda revelação. Sentados à mesa de um café, Lorène toca-lhe a orelha dolorida. O personagem-narrador pede-lhe cuidado, explicando que essa é sua "oreja mala”. Lorène brinca perguntando-lhe: “ ¿Tienes una oreja mala y otra 
buena?" (p. 226) A imagem assinala um ser cindido em duas partes opostas. Em seguida, Lorène pergunta-lhe como isso sucedera. Ele responde que tinha decidido cortá-la para dá-la de presente a uma mulher, mas que não teve coragem de chegar até o fim. Ora, aqui o texto explicita o ato de presentear, de troca, que representa o modo de esquecer objetivado na cena do guarda-chuva. Além disso, a mentira, a mentira aparente, participa do significado do diálogo. Antes o personagem-narrador havia comentado para a personagem que duvidara de sua resposta: "iEn las cosas pequeñas, yo nunca miento!" (p. 226) O estreitamento de intimidade que Lorène começava a empreender, acariciando o interior de sua orelha machucada como se quisesse adentrar em sua história, afasta-o. O personagem-narrador começa a contemplar a paisagem do "lago Mayor". Refuta o diminutivo "Manu" que Lorène utiliza para tratá-lo. Argumenta secamente que Manuel não é seu nome verdadeiro. Ela the contesta que já sabia, pois fizera algumas pesquisas a respeito. Enfim, as revelações entre ambos parecem começar a pôr fim ao jogo de mentiras que tacitamente haviam aceitado.

O personagem-narrador afasta-se ao contemplar a paisagem e evoca uma imagem que recupera a série de branco polissêmica empregada no texto:

"En la carretera de Brissago, el parabrisas de un coche en movimiento captura un rayo de sol y lo reverbera, cegador. Cierro los ojos: lentejuelas blancas, brillantes, se arremolinan detrás de mis párpados cerrados. Como sucede a menudo, con cualquier motivo." (p. 228)

Evadindo às perguntas de Lorène sobre sua orelha, sua história de vida, e tratando-a com um distanciamento seco, o personagem-narrador observa a beleza da paisagem, absorto, em estado de felicidade e beatitude. A beatitude novamente precede o que ele chama de "señal de despedida". O raio de sol que "reverbera, cegador" remete-nos aos efeitos de eco e de cegueira do Mal do campo representados nos dois primeiros capítulos do romance. As imagens brancas luminosas prenunciam a metonímia do campo, a neve. Ao abrir os olhos, ele sussurra: "La nieve" e ri, adivinhando ser um momento de "iAdiós a las nieves de antaño!" (p. 228) O carro da imagem evocada gira numa curva da estrada de Brissado. Seu estado de beatitude e o ponto de curva ultrapassado pelo carro na 
estrada sinalizam a retirada da memória da morte de Buchenwald e compõem os indícios da virada que sua vida dá naquele momento de revelação.

Durante toda a situação, o personagem-narrador nega-se a explicar a Lorène o motivo da "oreja mala" e quando Ihe escapa "la nieve" sussurrada, insiste no silêncio. A ignorância e a inocência de Lorène associam-se a um modo de salvação. $O$ esquecimento aqui se une à invenção de uma nova identidade e de uma nova vida. O pacto do personagem-narrador com Lorène consistia em que ela não conhecesse seu passado, seu verdadeiro nome, etc. Sua falsa identidade com Lorène transforma-o, por assim dizer, num personagem de ficção. Esquecer o eu que vivenciou Buchenwald significava reinventar-se para si e para o mundo, camuflando-se. É como se a imaginação e invenção de que a literatura está dotada penetrasse em sua vida real em forma de esquecimento do eu, justamente no vazio deixado pela renúncia do projeto de escrever uma ficção com sua experiência real de Buchenwald. A virada de sua história, portanto, supunha que a escrita agisse em sua vida reescrevendo e reinventando sua identidade e, em sentido oposto, a vida invadisse a escrita, obrigando-a ao anonimato do esquecimento, enclausurando-a numa zona morta de quietude e imobilização. Para inscrever-se na vida, o personagem-narrador não pôde escrever na vida. Não só a metáfora da escrita como inscrição e materialização da memória, da lembrança e do esquecimento, permeia o texto, mas também a da escrita como o tecer a vida e desfiar da vida em suas modalidades de vida e morte.

O quinto fragmento narra detalhadamente o episódio da queda do trem, após o qual o capítulo traz a resolução de sua cena central. Após cair e desmaiar ou desmaiar e cair do vagão, o personagem-narrador é levado à farmácia de Gros-Noyer-Saint-Prix, onde acorda e aos poucos recobra a consciência. Seu despertar da consciência dá-se quando se lembra da chegada em trem a Buchenwald. O episódio oferece-nos uma gênese da identidade do sobrevivente a partir do acidente da perda da memória; representa o reconhecimento da identidade através da perda e recuperação da memória de Buchenwald. É a recuperação da memória do campo implicada na perda da memória deste indivíduo que o leva à consciência de um eu. Em outras palavras, sua identidade 
tem como primeira memória, como origem, a experiência de Buchenwald. A perda da memória de Buchenwald significa a perda do eu na medida em que a consciência do seu ser, da existência do eu para o mundo e do mundo para o eu, fundamenta-se na relação permanente e sempre renovada que sua consciência estabelece com a memória pessoal do campo.

Ao acordar do "desvanecimiento", ocorre a perda da consciência do eu, de sua unidade separada do mundo, que é indicada pela presença de um campo de objetos indiferenciados que o personagem-narrador não era capaz de nomear. Assim, a perda da consciência associa-se à perda da linguagem. Esse momento de antes do verbo e do nome representa uma forma de origem: "Eran cosas que estaban allí y así empezó todo" (p. 230). Ele sente sair do nada. A narrativa distingue o despertar inconsciente do nada do despertar inconsciente onírico. Como a memória hábito não foi ativada, a sensação de sair do estado onírico para a vigília não se realiza de fato. $O$ sair do nada é sinalizado novamente pela impossibilidade de o personagem-narrador nomear as coisas, pela ausência de linguagem. O momento do surgir do nada, sem linguagem e sem poder dizer "eu" é identificado com um momento que antecede a existência do eu. O personagemnarrador então começa a reconhecer o sentido das palavras. O momento em que ele capta o sentido das palavras é corresponde a um momento de felicidade e de redescoberta do universo do dizível. Esse instante é comparado a uma luz que invadisse a imersão da consciência na escuridão da noite:

"Durante un segundo había temido que las primeras palabras no hubieran sido, en cierto modo, más que un destello repentino en una noche de silencio. Unas pocas palabras y luego nada más: un oscuro océano de objetos mudos." (p. 231)

A origem, o nascimento do eu, ocorre no ato recíproco de visibilidade entre o mundo e o eu:

\footnotetext{
"Me enderecé sin embargo, dolorosamente. Vi a un hombre vestido con una bata blanca que me observaba atentamente.

En ese preciso instante empecé a existir. Entonces empecé otra vez a saber que mi mirada contemplaba el mundo alrededor: ese minúsculo fragmento de universo donde había objetos de colores y un personaje con una bata blanca. Volví a ser $<y o>$ en ese instante preciso, bajo la mirada atenta de aquel hombre." (p. 232)
} 
O reconhecimento recíproco entre o eu e o mundo é o fato primordial que instaura a existência do eu. ${ }^{103}$ Mas a consciência de existir ainda não correspondia à consciência de ser. Segundo o narrador, a pergunta "quem sou?" ainda não podia ser respondida. Quando o personagem-narrador é informado pelo farmacêutico de que estava ferido, invade-Ihe um mal-estar "como un síntoma de la herida de la cual todavía no sabía nada concreto." (p. 232) Ele pressente que o reconhecimento do eu podia ser anunciado pelo sintoma de um ferimento. Tratase de uma identidade fundamentada na memória-ferimento, no trauma. Em seguida, ele reconhece sons variados, advindos de um entorno que ultrapassava seu campo de visão, o que the possibilita perceber a existência de um mundo mais vasto, mas tão desconhecido, segundo o narrador, como seu eu para si mesmo. Tateando na direção do "¿Quién soy yo?", o personagem-narrador indaga ao farmacêutico sobre quando e onde está. As noções de tempo e espaço erguem-se da memória como referências que sustentam o estar no mundo do indivíduo e sua identidade.

A descoberta do bilingüismo dá seqüência aos microacontecimentos do "desvanecimiento". As palavras vão surgindo em sua mente "en ráfagas dobles iluminadoras". Junto a essa descoberta de um mundo duplamente nomeável, ele sente "la dicha de vivir". O narrador associa sua felicidade de viver neste momento à ausência de memória pessoal. A lembrança das palavras não é acompanhada pela lembrança da sua experiência individual. $O$ desassossego chega quando a palavra "nieve" aparece primeiramente em espanhol para depois se desdobrar em "neige". O narrador a designa "palabra originaria", que contém "su significado más antiguo. El más primitivo, quizás." (p. 235) A experiência que dá origem à sua identidade une-se à sua língua materna. $A$ inquietação e o desassossego têm o poder de "ensombrecer confusamente la claridad irracional de (su) dicha de vivir."

\footnotetext{
${ }^{103}$ Segundo Angel G. Loureiro, a obra de Semprún está marcada por um tema dominante que é o desarraizamento, o estranhamento como atitude de estar no mundo, o sentir-se eterno estrangeiro. Essa identidade perdida, esse eu provisório, fantasmal, em permanente reconstrução, é tomado como uma vantagem e uma virtude tanto pelo escritor quanto por Loureiro, pois dela derivam a responsabilidade e a dívida em relação ao outro. Angel G. Loureiro demonstra como os procedimentos de desdobramento do eu, de imagens especulares de si a partir do outro na escritura autobiográfica de Semprún revelam a alteridade não só como um tema importante, mas também como um elemento construtor da obra. In LOUREIRO, Angel G.. "Semprún: Memorial de ausencias" in Cuadernos Hispanoamericanos, 617, Nov 2001, p. 21-29.
} 
A consciência de existir é expressa pela metáfora da luz. A consciência de ser é composta pela imagem da sombra. O ser do sobrevivente define-se pela passagem pelas trevas de Buchenwald.

Só quando o farmacêutico explica-lhe o acidente sofrido e o ferimento da orelha, ele recupera a memória por completo: "la memoria me volvió de golpe. Supe brutalmente quién era, dónde estaba y por qué." (p. 236) A narração então desliza para a memória da chegada de trem a Buchenwald, com a paisagem noturna, nevada, como imagem primeira. A consciência de uma identidade para o sobrevivente é indissociável da memória da experiência em Buchenwald. Uma experiência primordial que the confere a singularidade identitária, caracterizada pelo trauma e recuperada pela memória do ferimento:

"De este modo, a través del retorno de este recuerdo, de la desdicha de vivir, había sido expulsado de la dicha insensata del olvido. Había pasado de la deliciosa nada a la angustia de la vida." (p. 237)

Se a identidade deste sobrevivente tem como mito de fundação as lembranças do trauma, o esquecimento deste trauma comporta a perda da sua identidade. Para o personagem-narrador, a felicidade do esquecimento só pode ser insensata, ilusória, pois é a angústia da vida ancorada na memória da dor que representa sua realidade. Cair do trem, desmaiar, despertar, chegar a Buchenwald, ser expulso da plenitude insensata do esquecimento são eventos que reencenam o arquétipo da queda e da expulsão do paraíso, a aquisição do conhecimento terrível de distinguir o bem do mal e, portanto, a inevitável responsabilidade ética pelas conseqüências dos atos humanos. Para esta testemunha, a memória da queda, do sofrimento, tem um valor ético inaugural relativo à história pessoal, histórica e social do homem. No plano pessoal, a experiência em um campo de concentração de um deportado é reconhecida pelo narrador como um novo nascimento, uma origem, a memória-pátria e também uma espécie de eterno retorno mnemônico:

"Lo esencial era que había saltado en un estrépito de perros y de aullidos de los S.S. al andén de la estación de Buchenwald.

Ahí es donde había empezado todo. Donde todo siempre empezaba de nuevo." (p. 237) 
É importante notar que a noção de eternidade é mobilizada pelo narrador como um recurso literário que se liga à sua percepção subjetiva do período relativo a Buchenwald, ao valor de infinitude da matéria desta experiência e à maneira como se dá o processo de criação que a toma como objeto. $O$ eterno questiona e relativiza o regresso do personagem-narrador "à vida" na medida em que ele não chega a efetivar-se integralmente nunca, já que o que ocorre é um retorno provisório que se contrapõe e depende do eterno retorno ao campo. 0 eterno retorno (mítico) das lembranças de Buchenwald constitui um recurso simbólico que se apropria do eterno retorno (empírico) das lembranças, do caráter repetitivo e obsessivo das mesmas. Contudo, o eterno retorno de Buchenwald enquanto memória primordial não significa que a repetição das lembranças não inclua sua variação. O capítulo assim como a estrutura do romance baseia-se na forma espiralada cuja imagem serve de empréstimo à lógica dialética como ilustração de seu princípio de movimento e processo.

O desfecho do capítulo é bastante significativo quanto à dialética do idêntico e do não-idêntico no romance ligado ao episódio da negação da memória de Buchenwald. No último encontro do personagem-narrador com Lorène, antes de partir da Suíça, ele Ihe dá de presente a história da batalha de Gliéres de Morales, em que o companheiro foge pela neve profunda. Uma neve que não é igual àquela sussurrada pelo personagem-narrador junto a Lorène, nem mesmo a mesma de Morales, já que ele é quem ocupa o papel de Morales na história transformada ao narrá-la à amante. Poderíamos pensar que ele se apropria da experiência do companheiro morto para transmitir a Lorène a própria experiência da morte. A sua neve de Buchenwald, lembrança pessoal e coletiva ao mesmo tempo, é doada a Lorène disfarçada da neve do outro-universo concentracionário. Ele esconde e esquece a sua neve camuflando-a sob a neve do companheiro; ele esquece a si mesmo e Buchenwald lembrando as histórias de Morales como se fossem suas. Ou seja, a estratégia de esquecer implica lembrar-se como outro, camuflar-se sob um outro que não sobreviveu nem pode dar testemunho (não pode lembrar, falar, escrever, nem esquecer), mas que "vivenciou a morte" com(o) ele. Esse disfarce no texto representa uma ficção verdadeira, já que o 
sobrevivente tampouco pode lembrar, falar, escrever, sem morrer e, ao deixar de fazê-lo, sente-se morto como o outro.

A relação entre a história de Bakunin e o estratagema encontrado para esquecer não é explicitada pelo narrador que recorre a um paralelo ambíguo, eivado de usos imprecisos das palavras, elíptico. Assim como Bakunin deixa com a família de Lorène seu guarda-chuva, o personagem-narrador deixa com Lorène a neve, a memória de Buchenwald, em uma cripta-vitrine que corresponde ao lugar do esquecimento em sua mente. Tal obséquio, triunfo de seu fracasso, é oferecido através de uma narração mediatizada na qual a neve de Buchenwald é trocada pela neve das histórias de Morales, companheiro de campo ignorado pela personagem. Lorène propõe-lhe "enseñar" o guarda-chuva de Bakunin e, ao final, é qualificada como a "maestra" do esquecimento. A neve pela qual Morales fugia oculta e revela, ao mesmo tempo; camufla a neve metonímica e metafórica de Buchenwald, símbolo da escura eternidade glacial da morte radiante do campo.

Somente a narração está incluída no diálogo com Lorène através da história da batalha de Gliêres de Morales. A impossibilidade de rememorar a experiência do campo reflete-se na ausência das formas discursivas no diálogo entre ambos.

A aporia do regresso de Buchenwald ao mundo exterior prossegue com um sentido dialético e paradoxal. Regressar à vida fora do campo equivale a ingressar as lembranças da morte na região morta da memória, no esquecimento, mediante a criação de um espaço discursivo para colocar o que está sepultado, a história de Morales. Só assim, colocando a vida na morte e a morte na vida, sepultando as próprias lembranças e recriando as lembranças mortas alheias, o sobrevivente consegue camuflar-se para adequar-se ao mundo.

A segunda parte do romance corrobora o sentido dialético da história narrada, pois representa um movimento de negação do que se vinha radicalizando na vida deste sobrevivente. Ele não pode esquecer e calar sem perder a própria identidade, portanto o que ele realiza também é uma forma de morte. ${ }^{104} \mathrm{~A}$

\footnotetext{
104 Semprún cita as palavras de Elie Wiesel para corroborar sua posição acerca da necessidade e da responsabilidade de falar apesar da impossibilidade: “'No se puede contar; pero no se debe silenciar', ha dicho Elie Wiesel, superviviente de Auschwitz y del pequeño campo de concentración de Buchenwald. Yo también voy a hablar. Asumo por tanto la responsabilidad de hablar en nombre de tanto silencio acumulado,
} 
narrativa questiona a liberdade e o poder de esquecer mediante o esquecimento como camuflagem da identidade de sobrevivente testemunha escritor. Esta estratégia de sobrevivência conflui com o caminho da morte não idêntica àquela vivenciada em Buchenwald, mas indissociável da mesma. Trata-se de uma outra forma de morte e de sobrevivência derivadas da primeira. Estamos no momento da primeira virada da curva da espiral: o lembrar transforma-se em esquecer. Porém essa transformação não pode ser tomada sob a ótica da lógica formal pela qual esquecer exclui lembrar sem possibilidade de relação mútua. $\mathrm{Na}$ fase do esquecimento, as lembranças de Buchenwald e a escrita estão presentes de maneira negativa, em forma de ausência; são recalcadas e relegadas ao inconsciente. A forma espiralada e fragmentária do romance representa nesta fase da narrativa um modo de reportar-se à repetição da lembrança da morte do campo na vida de fora e depois do campo, que resulta em um tormento dilacerante para o sobrevivente que o leva, em dado momento, a silenciar esta morte, através do esquecimento e da renúncia à escrita, para que a morte não silencie sua vida.

\section{Síntese: a diferenciação como aporia do regresso da morte e à morte}

A terceira parte do romance, a síntese, tem como sentido dialético organizador a diferenciação. $O$ eu recalcado ressurge do esquecimento silencioso como um monstro dotado de anomalias que, porém, são assumidas pelo sobrevivente enquanto objeto de orgulho, como singularidade de sua identidade proveniente da catástrofe. Do ponto de vista do movimento dialético do texto, a aporia do regresso à vida radicaliza-se em sua negação: o que ocorre é um regresso da morte e à morte, a partir do qual esse regresso impossível à vida

\footnotetext{
de tantas muertes silenciosas y anónimas." Mas o ato de falar para Semprún sempre está vinculado a um "como" falar. Ele repudia a fala autocomplacente da vítima e defende um rememorar crítico: "Por un lado debemos hacer una reflexión crítica del pasado. No podemos ni debemos darnos por contentos representando el papel de víctima o de héroe. (...) Ya sabemos que ambas cosas evitan la mirada crítica, rechazan el examen de conciencia autocrítico. Los héroes y las víctimas son personajes de una sola pieza, inflexibles, monolíticos, carentes de contradicciones." In SEMPRÚN, Jorge. "Weimar, Buchenwald (1995)" in Pensar en Europa. Barcelona: Tusquets, 2006, p. 158-159.
} 
realiza-se em sua negatividade, produzindo o processo de diferenciação do personagem-narrador. Nesta parte do romance, o personagem-narrador contrapõe-se ao esquecimento de Buchenwald, assumindo a fase negada e seu passado, o que engendra sua transformação em um sobrevivente testemunha escritor. Porém, essa identidade implica uma estabilidade provisória, uma constante superação, uma vez que, como ele rememora seu passado através da escrita, sempre tem de enfrentar a morte.

Do ponto de vista interno, os capítulos seguem um movimento dialético entre si. O oitavo capítulo representa a invasão do eu testemunha, que saiu de Buchenwald e abandonou o projeto de escrita, na vida do personagem-narrador através da escrita quando Primo Levi deixa a vida e sua atividade de testemunhar. O nono capítulo representa as condições que possibilitaram essa invasão, ou seja, sua transformação anterior em escritor: a expulsão do personagem-narrador do Partido Comunista Espanhol e seu contato com as leituras de Kafka. O décimo capítulo representa o encontro com o eu passado ao retornar a Buchenwald e a revelação de que a história de sua origem, de sua identidade de sobrevivente, é diferente da história que ele conhecia, o que o faz reconhecer-se como outro para si mesmo. Invasão, expulsão e encontro formam a tese, a antítese e a síntese deste processo.

\subsection{A invasão do Mal do campo na escrita}

O oitavo capítulo do romance, "El día de la muerte de Primo Levi" narra o reaparecimento do eu testemunha reprimido como um diálogo impositivo deste fantasma com a escrita. A ação principal do capítulo desenvolve-se em torno da aparição da testemunha oriunda de Buchenwald, de sua voz e memória, na escrita literária do personagem-narrador em coincidência com a morte de Primo Levi e com o aniversário da libertação de Buchenwald. No dia 11 de abril de 1987, enquanto ele escreve seu romance Netchaiev ha vuelto, as lembranças de Buchenwald aparecem em seu rascunho sob a voz de um outro narrador, diferente daquele que enunciava no romance. Aqui, o personagem-narrador é transformado 
em personagem-autor de Netchaiev ha vuelto. De modo que o narrador de La escritura o la vida transforma-se, por sua vez, em personagem de outro romance. Esta é uma de suas origens. O personagem-narrador identifica esse episódio com o retorno do eu testemunha, abandonado em 1945, logo após a libertação do campo, e com o começo de um novo romance testemunhal, "La escritura o la muerte". Ao dia seguinte, ele ouve na rádio a notícia de que Primo Levi se matara na noite anterior, jogando-se do alto da escadaria de seu prédio.

Assim, imediatamente, o capítulo estabelece uma relação dialética com o anterior. Trata-se não somente do retorno das lembranças de Buchenwald, mas da identidade que buscou testemunhá-las, naquele momento após a libertação, através de um projeto de escrita e de um eu narrador que tiveram de ser abandonados. A volta das lembranças daquela identidade negada é a negação de seu esquecimento, mas também acarreta uma negação da vida do personagemnarrador com o perigo da rememoração da experiência da morte. O suicídio de Primo Levi no mesmo dia em que sua identidade de testemunha ressurge aponta para esse sentido de risco de morte. $O$ eu testemunha esquecido invade a narrativa e estabelece um diálogo com o eu do personagem-narrador, contrapondo-se e diferenciando-se de outras vozes que o acompanham neste ressurgimento. A morte volta impondo-se na instância dialógica da escrita literária e através desta imposição reconstituindo o eu testemunha perdido.

Do ponto de vista do narrador, a coincidência da morte de Primo Levi com a aparição do fantasma de Buchenwald é pouco casual, o que the confere na estrutura do enredo o estatuto de motivo pelo qual o narrador dialoga com a escrita testemunhal de Primo Levi. Um diálogo cuja lógica interna é dialética. $\mathrm{O}$ eu esquecido, relegado aos subterrâneos da memória, invade a escrita como se tivesse retomando seu lugar. A morte de Primo Levi, que coincide com o assalto da memória do campo de concentração ao personagem-narrador, contrapõe-se ao ressurgimento do narrador testemunha, o "ressuscitado". O paralelo antitético sugere que a morte alcança Primo Levi assim como alcança a escrita do personagem-narrador. Primo Levi inscreve-se no branco do vazio, atirando-se no oco da escadaria, assim como o branco do vazio da morte inscreve-se na página 
em branco do personagem-narrador, no seu oco. Essas invasões dicotômicas permitem um diálogo entre a escrita do personagem-narrador e a de Primo Levi. É como se a morte da escrita de Primo Levi proporcionasse vida à escrita da morte do personagem-narrador, engendrando $o$ processo de transformação e diferenciação de sua identidade. A tensão entre a perspectiva do personagemnarrador e a do narrador delineia a profusão deste diálogo. $O$ eu que invade sua escrita neste momento impõe-se em sua singularidade irrevogável: a primeira pessoa não permite assumir a perspectiva de um outro, sobre a qual este eu se projetaria para enxergar-se. O eu testemunha não cede lugar a uma terceira pessoa para ganhar vida, pois sua vida não pode ser compartilhada ou compreendida por outro qualquer. A singularidade da experiência, fundamentada na própria impotência de suportá-la, exige a singularidade da primeira pessoa, um foco irredutível.

A narração entra em tensão dialógica e dialética com o intertexto intruso. $O$ narrador dialoga contrapondo-se à voz do fantasma sobrevivente oriundo de Buchenwald e à voz do narrador testemunha de Primo Levi. A narrativa representa assim a invasão da voz da testemunha como um impulso que domina a enunciação e a vida do sobrevivente da catástrofe e representa a perda da voz da testemunha como uma submissão à sua força destrutiva que a expulsa da vida e da escrita. A narração, a descrição, a reflexão e a poesia figuram neste monólogo dialogizado e neste diálogo entre escritas de testemunhas do Holocausto, que morrem para a vida da escrita e ressurgem para a escrita da morte.

O intertexto consiste no princípio organizador do capítulo. Em cada um de seus fragmentos aparece um trecho de um testemunho literário do personagemautor ou de outra testemunha que dialoga e entra em antagonismo com a voz da testemunha de Buchenwald, narrador de La escritura o la vida, que surge na escrita de Netchaiev ha vuelto. Através deste diálogo intertextual, a voz da testemunha de Buchenwald vai se transformando na voz deste narrador, o que objetiva o processo de elaboração e diferenciação de sua identidade.

O presente verbal não é mais empregado, o que amplia o foco narrativo. Esta mudança de perspectiva neste momento do romance ajusta-se ao processo de 
diferenciação: o eu que escreve agora toma distância daquele que foi e aponta a transformação que ele quer representar. A diferenciação da identidade implica um distanciamento de perspectiva em face do eu passado. Além disso, o salto temporal da narrativa de 1945 a 1987 torna verossímil a perspectiva distanciada. O eu de 1987, mais próximo do sujeito da enunciação, permite que o narrador prescinda da perspectiva "com" o personagem-narrador construída pelo presente verbal. ${ }^{105}$

Num sábado, dia 11 de abril de 1987, o personagem-autor dá-se conta de que as páginas que escrevia de seu romance Netchaiev ha vuelto não seriam conservadas, pois a morte de antanho havia invadido "su borrador". A narrativa expõe a cena central do capítulo no primeiro fragmento, anunciando o sentido dialético que conformará sua construção. A noção de "borrador" como instrumento do processo de criação literária, a da não conservação das páginas escritas naquele dia e a informação de que o título do romance Un homme perdu seria alterado para Netchaiev est de retour articulam-se com a idéia de provisório, transitório, ligada à escrita. O provisório do processo de escrita confronta-se com a perenidade da memória de Buchenwald. O personagem-autor escrevia em seus manuscritos a travessia de Roger Marroux pela Alemanha derrotada, em abril de 1945, em busca de Michel Laurençon, seu camarada de Resistência deportado. A passagem do personagem por Buchenwald seria curta, um parágrafo, transcrito em La escritura o la vida. O personagem-autor relê a frase e hesita insatisfeito, pois a forma da escrita estava carregada de informações triviais. Em seguida, ele sente "un malestar indistinto y sordo" que o submerge numa "meditación desenganada" e o leva a uma região em que "las cosas empezaban a moverse en

\footnotetext{
${ }^{105} \mathrm{O}$ recurso do presente verbal neste romance incide sobre uma característica do testemunho, apontada por Alfredo Bosi em "A escrita do testemunho em Memórias do Cárcere", que consiste na presença de um eu testemunha sempre "em situação" narrativa. Pensamos que essa característica é recorrente no modo de representação desta forma literária. Parece que a necessidade que a testemunha escritor experimenta de transmitir fielmente a experiência traumática por que passou relaciona-se com um modo de narrá-la que nos aproxime de suas emoções, sentimentos, estados de espírito, reações, pensamentos e do desenvolvimento dos mesmos em íntima relação com o tempo dos acontecimentos. Daí o encurtamento da distância estética ser empregado com freqüência pelos narradores testemunhas, já que constitui o modo de narrar pelo qual se associam e se vêem contemplados três elementos recorrentes enquanto passagens das histórias da experiência da catástrofe e forma de vivenciá-la e percebê-la do ponto de vista das testemunhas. A saber, a urgência de narrar, o súbito e a queda. In BOSI, Alfredo. "A escrita do testemunho em Memórias do Cárcere" in Estudos avançados, v. 9, n. 23, janeiro-abril 1995, p. 309-322.
} 
la memoria". Trata-se do fluxo inconsciente que irrompe como um magma vulcânico não casualmente no aniversário da libertação de Buchenwald. Na frase que tratava da chegada de Marroux a Buchenwald, o personagem-narrador havia posto como data o dia posterior à libertação do campo, 12 de abril de 1945: "La había escrito sin pensarla, pues venía impuesta por la verdad histórica." (p. 243) 0 surpreendente era que ele escrevia no dia 11 de abril de 1987. A "imposição" da verdade histórica é acompanhada pela invasão do inconsciente: "Una estrategia del inconsciente, no obstante, suave y solapada en sus formas, brutal en su exigencia, me había conducido a describir esta llegada el mismo día del aniversario del acontecimiento" (p. 243). A memória inconsciente vincula-se à substância perene da vida que se move debaixo da superficialidade e das aparências passageiras do cotidiano.

$\mathrm{Na}$ seqüência, o narrador reflete sobre sua tentativa passada de esquecer Buchenwald, ressaltando a negatividade dessa tarefa impossível. Afirma ter supervalorizado suas forças, ter sido orgulhoso pensando que poderia esquecer Buchenwald no cotidiano e escrever sobre essa experiência ao mesmo tempo. Designa tal concomitância uma "esquizofrenia concertada", uma "elección radical". Percebe sua amnésia voluntária sistemática uma crueldade contra si mesmo e a beatitude do esquecimento é considerada "obnubilada", juntamente com os anos de pós-guerra em que houve uma onda de "anonimato colectivo". Se o esquecimento conferiu-Ihe certa tranqüilidade de espírito, ele observa que ela foi interrompida inúmeras vezes, conquistada custosamente e que seu domínio era "provisional, renovado sin cesar."

Segundo o narrador, El largo viaje marca o momento da virada em sua vida em que se estabelece uma transformação radical: a do domínio sobre a memória de Buchenwald e sua vida não mais através do esquecimento e sim rememorando seu passado mediante a escrita literária. Porém, conforme a visão do narrador, esse domínio implicaria uma submissão ao poder das angústias mortíferas de antanho. A atividade literária testemunhal exigia-lhe suportar um estar no mundo provisório, posto que a atualização de suas lembranças acarretava o perigo de 
vida permanente. Trata-se de um poder contraditório que se exerce mediante a submissão ao poder das lembranças contra o qual luta.

O regresso das lembranças de Buchenwald manifesta-se como um reencontro de uma parte "áspera y profunda" sua contra si mesmo, numa data marcada pela memória da morte: "acudía fiel (...) a la cita de la memoria y de la muerte." (p. 243) A imagem construída pela narrativa é a de um reencontro que ocorre graças a um desvio imprevisto de rumo na escrita do personagem-autor. $A$ palavra "derivar" é empregada recorrentemente.

O título do romance Netchaiev ha vuelto refere-se a um revolucionário cuja ação militante deriva em terrorismo. ${ }^{106}$ A alusão à história de Netchaiev tem um paralelo com a forma de regresso das lembranças de Buchenwald. Conforme a descrição, estas surgem de uma zona sombria, nebulosa, que conforma o esquecimento e constituem seus "tesoros ocultos, obliterados" em uma "memoria inagotable." A escrita transforma-se no meio pelo qual essas lembranças são recuperadas. O verbo "recuperar" aparece com freqüência na descrição do processo de escrita de Netchaiev ha vuelto. O romance recuperava um tema já trabalhado no filme La guerra ha terminado. ${ }^{107}$ Tratava-se da transformação da

\footnotetext{
${ }^{106}$ Sergei Netchaiev (1847-1882), anarquista revolucionário, conhecido por uma prática terrorista tenaz que o leva a divergir de Bakunin e ser banido pelo mesmo do grupo anarquista que formava a partir de 1870 . Há uma polêmica sobre a autoria de "O Catecismo Revolucionário". Alguns atribuem-na a Bakunin, outros a Netchaiev, outros ainda a ambos. Sua vida atribulada, cheia de prisões e conspirações, faz desse revolucionário uma figura carismática admirada e repudiada. É famoso seu preceito de que "os fins justificam os meios". Foi um dos maiores militantes anarquistas do séc. XIX por suas atitudes terroristas. Responsável pela tática da "propaganda pelo ato", que significava realizar atos de assassinato de grandes figuras políticas e de terrorismo contra a burguesia, com o objetivo de estimular insurreições populares. Priorizava métodos de guerrilha e de formação de grupos de afinidade com intenções revolucionárias. Na sua obra declara que o revolucionário é um indivíduo marcado, não tem interesses nem sentimentos pessoais, nem laços, nada que lhe seja particular, nem sequer o nome. Tudo nele é absorvido com vista a um único interesse, a Revolução. O capítulo faz uma analogia entre a forma de ação terrorista de Netchaiev, baseada na violência e na fraude, com a forma de ação da memória de Buchenwald. Além disso, parte da investigação biográfica de Netchaiev afirma que este traiu Bakunin por provocar conflitos nos círculos dos exilados russos na Europa e por haverlhe roubado a autoria do livro, acusando-o de ser responsável então pela expulsão de Bukunin do movimento socialista russo.

${ }^{107}$ La guerre est finie (1966) é um filme dirigido por Alain Resnais. Semprún escreveu o roteiro. José Antonio Pérez Bowie resume seu argumento da seguinte maneira: "se centra en el deambular incesante del protagonista, Diego Mora, militante de un partido español en el exilio (no se nombra explícitamente al partido comunista, aunque todas las referencias son suficientemente claras) a la búsqueda angustiosa de los contactos que garantizan la acción clandestina; su deambular es contrapunteado por las discusiones con otros miembros del partido, cuya visión desenfocada de la realidad española no comparte, y con miembros radicales de la generación más joven con cuya apelación a la violencia armada para forzar el curso de los acontecimientos tampoco pareces estar de acuerdo. A la vez, una voz en off va exteriorizando las reflexiones del personaje en
} 
ação militante em violência desmedida. As paisagens do bairro de Montparnasse utilizadas para a filmagem, onde se situava o cemitério em que César Vallejo estava enterrado, voltavam à sua memória à hora de escrever o romance. $\mathrm{O}$ reencontro consigo mesmo dá-se mediante a ação contraditória de derivação e recuperação da escrita, "subrepticiamente", como uma "aparición repentina, insidiosamente concertada". É como se os antigos ardis e censuras da consciência que se empenhava em esquecer fossem burlados pelos estratagemas do inconsciente. A imagem faz alusão à luta revolucionária defendida por Netchaiev. Para recuperar o poder, a luta deriva em violência, em invasão. $O$ consciente que procurava paz é derrotado pela ação inconsciente que mina essa trégua. "Bakunin é derrotado por Netchaiev. Temos a imagem da invasão violenta das lembranças em Un homme perdu enquanto invasão do eu de Buchenwald:

\begin{abstract}
"Así, el 11 de abril de 1987 (...) había acabado por encontrarme de nuevo conmigo mismo. Por recuperar una parte esencial de mí, de mi memoria, que había estado, que seguía estando obligado a reprimir, a mantener en vereda, para poder continuar viviendo. (...) Subrepticiamente, a la vuelta de una página de ficción que en un primer momento no parecía que fuera a exigir mi presencia, yo aparecía en el relato novelesco, con la sombra devastada de esta memoria como único equipaje.
\end{abstract}

Yo invadía el relato incluso." (p. 247)

$\mathrm{O}$ eu de Buchenwald registra-se em primeira pessoa. A narrativa descreve esse registro como um deslocamento: "A partir de ese momento, en efecto, la escritura se había orientado hacia la primera persona del singular." (p. 247) As lembranças da testemunha caracterizam-se por uma singularidade solitária ou uma solidão singular. A escrita então flui impetuosa e facilmente, com palavras certeiras. Mas o personagem-autor deixa de lado as páginas escritas e volta à "tercera persona de lo universal": "Me expulsé del relato." (p. 247) O trecho retomado da chegada de Marroux é transcrito no romance. A situação narrativa do intertexto é a mesma do primeiro capítulo de La escritura o la vida, com a ressalva da perspectiva diferenciada: “_Parece usted sorprendido... ¿Qué le pasa? ¿Es el silencio? Nunca hay pájaros en este bosque... Al parecer, el humo de los hornos

las que muestra su desencanto y su conciencia de la inutilidad de la labor en que se encuentra embarcado." In BOWIE, José Antonio Pérez. "Dos reflexiones cinematográficas sobre el exilio: El ángel exterminador de Buñuel y La guerra ha terminado de Resnais-Semprún” in Nueva Literatura Hispánica, n. 3, 1999, p. 168. 
crematorios los ha hecho huir... - Soltó una risita-. Pero el horno se paró ayer... (...)" (p. 247-248) Marroux encontra-se com o narrador de nosso romance à entrada do campo. O personagem-autor recebe este eu do passado com um riso e "una especie de orgullo insensato" por notar que suas lembranças continuavam "conservando su resplandor de nieve y de humo, como el primer día." (p. 248) Neste momento, a narrativa realiza o desdobramento da identidade do personagem-narrador através do diálogo com seu eu de Buchenwald, tratando-o de tu. Trata-se de um diálogo que reitera a singularidade e o poder da identidade oriunda da experiência do campo sobre a vida do narrador: "Nadie puede imaginar hasta qué punto esta singularidad gobierna solapadamente tu vida: tu cansancio de la vida, tu avidez de vivir". (p. 248) Uma singularidade que se define pelo poder de vida e de morte desta identidade. O lugar mortífero, inabitável e insubstituível desta identidade é o que lhe desperta esse "orgullo tenebroso de (su) soledad." 108

O romance constrói a visão de que o sobrevivente precisou transformar-se em um outro, negar-se e estranhar-se mediante o esquecimento, o silêncio e a renúncia à escrita deste eu para enganar e destituir seu poder de aniquilação. Mas essa identidade profunda e subversiva volta a aterrorizá-lo insolentemente, minando as represas do personagem-autor ao afluir em sua escrita.

No andamento da narração das formas de regresso que as lembranças desta identidade assumem, o quarto fragmento apresenta o nascimento de um novo livro. O reencontro do eu de Buchenwald com o personagem-autor na escrita origina o romance que lemos. Os dois primeiros parágrafos de La escritura o la vida são reinscritos. ${ }^{109} \mathrm{O}$ processo de escrever a obra dentro da obra torna o

\footnotetext{
${ }^{108}$ Jeanne Marie Gagnebin analisa a dificuldade de que os sobreviventes dos genocídios do Estado moderno encontram diante da elaboração de sua vivência. A autora mostra como o texto de Freud, "Erinnern, wiederholen und durcharbeiten", está implícita e explicitamente presente no pensamento de Adorno e de Paul Ricoeur. Segundo Gagnebin, ambos fazem uma analogia entre o conceito clínico de Freud de perlaboração do passado com os processos coletivos de trabalho da memória. O processo individual de elaboração do trauma implica, conforme palavras de Freud citadas por Gagnebin a partir de uma citação de Ricouer, "adquirir a coragem de fixar sua atenção sobre as manifestações de sua doença. Sua própria doença não pode mais ser para ele algo vergonhoso, ela deve se tornar um adversário digno, uma parte de sua essência, cuja presença tem boas motivações e da qual poderá extrair elementos preciosos para sua vida posterior." In GAGNEBIN, Jeanne Marie. "Por que elaborar o passado?" in Lembrar escrever esquecer. São Paulo: Editora 34, 2006, p. 104.

${ }^{109}$ Para a clareza da análise, reproduzimos o trecho: "Están delante de mí, abriendo los ojos enormemente, y yo me veo de golpe en esa mirada de espanto: en su pavor.
} 
processo de representação do real através da linguagem a matéria desta representação. ${ }^{110}$ Esse momento da curva da espiral assinala um golpe da escritura do desastre na passividade, no esquecimento e no silêncio que the são consubstanciais. A escrita do desastre nasce da negação da catástrofe enquanto reflexão de sua negatividade. A repetição do início de La escritura o la vida nessa situação narrativa ilustra a reflexão do real enquanto imagem refletora, raio $\mathrm{x}$ do embrião da obra que registra um momento de nascimento irrefletido.

O narrador descreve o estilo característico de seus escritos testemunhais sobre a Shoah: de progressão lenta e dolorosa, que demoram em amadurecer, de publicação prematura porque jamais finalizados inteiramente; abandonados e retomados reiteradamente, reescritos sob um padecimento impositivo. Entrevemos a imagem da custosa gestação de um filho querido e rechaçado. $O$ título que nasce com os primeiros rascunhos, "La escritura o la muerte", corrobora o sentido dialético do desenvolvimento da matéria. A escrita não é simplesmente a morte que se opõe à vida quando ele precisa após ter sobrevivido esquecer Buchenwald. Não é tampouco a vida que se opõe à morte como uma necessidade de assumir a identidade de sobrevivente testemunhando sobre sua experiência. É, dialeticamente, a negação e a afirmação da vida e da morte, sob aspectos diferentes, simultâneos e sucessivos.

Junto à anotação do título do livro, o personagem-autor aponta o nome Laurence, namorada de Marc, o soldado francês morto que escreve uma carta à sua namorada contando-lhe seu encontro com o sobrevivente. Esses episódios aparecem sob perspectivas diferentes no terceiro e quinto capítulos do romance. As palavras e a perspectiva de Marc seriam apropriadas pelo personagem-autor para começar a obra. Além disso, o narrador comenta a inaptidão de Laurence aos prazeres da vida. É como se as duas referências iniciais do livro incidissem nas palavras da morte.

Desde hacía dos años, yo vivía sin rostro. No hay espejos en Buchenwald. veía mi cuerpo, su delgadez creciente, una vez por semana, en las duchas. Ningún rostro, sobre ese cuerpo irrisorio. Con la mano, a veces, reseguía el perfil de las cejas, los pómulos prominentes, las mejillas hundidas..." (p. 248-249)

${ }^{110}$ Sabemos pela análise de Davi Arrigucci que esse jogo encalacrado e perigoso em Cortázar tende à destruição da ficção e do real por seu caráter de permutabilidade dialética. In ARRIGUCCI JR., Davi. $O$ escorpião encalacrado - A poética da destruição em Julio Cortázar. São Paulo: Companhia das Letras, 2003. 
A volta das lembranças de Buchenwald afigura-se no quinto fragmento sob o aspecto do retorno de um câncer ligado à dialética do sonho e da realidade:

"La velada del sábado 11 de abril de 1987 discurrió como discurren las veladas cuando estos recuerdos se imponen, proliferan, devorando lo real mediante un procedimiento de metástasis fulminantes." (p. 252)

O personagem-narrador jantava e bebia com uns amigos e sentia que 0 limite que separava a realidade do sonho desfazia-se sob o desassossego que as lembranças desencadeavam. A "dicha aparente" recobria mas não se distinguia da "angustia profunda". A realidade cinde-se em dois territórios opostos porém indistinguíveis. O narrador evoca as palavras de La trégua de Primo Levi referentes à imagem do sonho dentro de outro sonho: " $<\dot{E}$ un sogno entro un sogno, vario nei particolari, único nella sostanza...>"(p. 253) A voz do sonho de Primo Levi oferece a imagem do curso de um rio ao qual o narrador é arrastado:

\footnotetext{
"Nada puede detener, dice Levi, el curso de este sueño, nada puede distraer de la angustia que hace manar, sordamente. Aunque la gente se gire hacia uno, aunque te tienda una mano amiga. (...) Aunque hayan adivinado lo que te está sucediendo, lo que te está sumergiendo, aniquilando. Nada jamás desviará el curso de este sueño, el flujo de esta laguna Estingia." (p.253-254)
}

O narrador é arrastado por sua angústia fluvial que mana surdamente de seu interior e o faz submergir como nas águas da lagoa dos Hades. O atributo desta angústia onírica fluvial é a sua onipotência e onipresença: nada pode impedir seu fluxo cuja força se impõe ao sobrevivente sem salvação. As lembranças de Buchenwald assumem aqui o caráter de desastre: a passividade do sobrevivente frente à imposição das lembranças é total. A narrativa recorre à descrição do caos, do torvelinho, do vazio nebuloso do sonho de Levi para caracterizar o desastre: "<Tutto è ora volto in caos: sono solo al centro di un nulla grigio e torbido, ed ecco, io so che cosa questo significa, ed anche di averlo sempre saputo..>." (p. 254) O diálogo com o sonho testemunhado por Levi oferece um contraponto à voz da testemunha de La escritura o la vida ao iluminar também a dialética entre o idêntico e o não-idêntico, o superficial e o profundo, a aparência e a essência.

A coincidência não casual entre a data da leitura de La tregua e a publicação de El largo viaje encerra as facetas contíguas e antitéticas entre leitura e escrita, 
tempo do esquecimento e tempo da lembrança. O personagem-narrador lê $\mathrm{La}$ tregua em 1963, ano em que publica El largo viaje: "Pues en 1963, en otoño, el tiempo del silencio y del olvido había quedado atrás. El tiempo de la sordera para conmigo mismo también: para con la parte más oscura pero más verdadera de mí mismo." (p. 255) O devir das águas surdas das lembranças oníricas desperta-o para a surdez, para a inconsciência de estar no mundo esquecido do conhecimento pessoal e histórico do desastre.

O narrador rememora o sonho com Buchenwald em 1961 que prenunciou a escrita de El largo viaje. Ele era dirigente do Partido Comunista Espanhol e vivia clandestinamente em Madri. Na ocasião, a polícia franquista havia feito várias detenções, conseqüentemente o militante evitava sair de seu esconderijo. Neste contexto, Manuel A., militante que o hospedava e ex-prisioneiro de Mauthausen, contava-lhe sua experiência nesse campo nazista. A posição de audiência passiva do personagem-narrador e a forma desordenada dos relatos de Manuel contribuíram para que suas lembranças do campo aflorassem após dezesseis anos. O ambiente clandestino, a identidade falsa do personagem-narrador, a impossibilidade de falar sobre Buchenwald e o estranhamento com uma história que lhe pertencia criaram uma atmosfera sufocante, uma espécie de internação na memória do campo que acabou por impregná-lo e despertar seu inconsciente. A repressão do regime franquista rompia o controle que o sobrevivente exercia sobre si e irrompia em seu inconsciente como lembranças confinadas: "Desde hacía 15 años, ya nunca más había caído la nieve sobre mi sueño. La tenía olvidada, reprimida, censurada. Controlaba mis sueño, había expulsado de ellos la nieve y el humo sobre el Ettersberg." (p. 259)

As lembranças de Buchenwald voltam no sexto fragmento como o sonho da neve. O caráter desse sonho é expresso pela figura da catacrese: "Había nevado aquella noche sobre mi sueño." (p. 255) A imagem imprópria se tomada literalmente traduz o ultra-realismo da experiência do campo. É como se a neve atuasse de fora do sonho sobre o sonho. A narrativa combina a catacrese à elipse. Progressivamente as descrições repetitivas vão omitindo a ação da neve sobre o 
sonho até que o sonho a incorpora: "Pero había habido nieve, aquella noche, en mi sueño." (p. 255) passa a "Nieve, en mi sueño, al cabo de tantos años." (p. 255)

O testemunho de Manuel A. contrapõe-se à forma de testemunho considerada pelo narrador capaz de aproximar-se da "verdade" do Holocausto. "Desordenado, confuso, demasiado prolijo", com "detalles ociosos", o testemunho do sobrevivente de Mauthausen não permitia que o personagem-narrador se reconhecesse e identificasse uma essência em comum entre as realidades de Buchenwald e Mauthausen. A veracidade dos fatos perde-se em função da ausência de verossimilhança: "Su sinceridad indiscutible ya sólo era retórica, su veracidad ya ni siquiera resultaba verosímil." (p. 258) Mas é justamente esse jorro caótico de palavras que o convocara através de seu sonho a dar testemunho daquela realidade: "Una noche, de repente, trás una dilatada semana de relatos de estas características, se puso a nevar en mi sueño". (p. 258)

Assim o sonho da neve de antanho realizava um novo despertar na vida do sobrevivente. Neste novo despertar, a angústia carregada por aquelas lembranças apaziguava-se, o que the permitia escrever:

"Pero la nieve había desaparecido de mi sueño. Me desperté sobresaltado (...) Pero la palabra <sobresaltado>, pensándolo bien, resulta impropia. Me había despertado de golpe, sin duda, encontrándome despierto de inmediato, lúcido, listo. Pero no era la angustia lo que me despertaba, tampoco el desasosiego. Me encontraba curiosamente tranquilo, sereno." (p. 260)

Ao amanhecer, o personagem-narrador escreve as primeiras palavras de $E I$ largo viaje. A imagem do romper do dia simboliza a nova transformação ocorrida na vida deste sobrevivente. Em suas primeiras palavras solares, a dor aguda que antes atravessava seu coração - "A veces, sin duda, un dolor agudo, breve, me había atravesado el corazón" (p. 259, itálico nosso) - transforma-se em: "'Hay este amontonamiento de cuerpos en el vagón, este dolor punzante en la rodilla derecha..." (p. 260, itálico nosso) Trata-se das primeiras linhas do romance El largo viaje transcritas ao final do fragmento.

No sétimo fragmento, a digressão sobre La tregua inclui uma digressão sobre o personagem Juan Larrea de La montaña blanca que problematiza a dialética entre ficção e realidade, objetivando uma relação inclusiva entre as duas esferas. 
O narrador comenta que quando leu em 1961 a última página de La tregua em que se insere a frase de Levi "un sogno entro un altro sogno", ele fechou os olhos. O narrador considera o trecho de Levi familiar e fraterno, ao contrário do testemunho de Manuel. Em seguida, a narrativa remonta a 11 de abril de 1987, quando o personagem-autor se lembrou de Primo Levi e de Juan Larrea, personagem cujas lembranças continham as frases dos livros de Levi. O protagonista Juan Larrea de La montaña blanca suicida-se nas águas do rio Sena porque "se había acordado del olor del horno crematorio sobre el Ettersberg" ( $p$. 261) Isto é, não conseguiu conter-se, no duplo sentido de carregar e reprimir as lembranças do campo.

Em 1986, data de publicação de La montaña blanca, o personagem-autor é questionado sobre a semelhança entre si e o personagem Larrea. A identificação entre os dados biográficos de Larrea e os do personagem-autor é ironizada pelo narrador para o qual toda criação literária possui uma parcela de identificação com o real e uma que lhe escapa ainda que esteja englobada nele ou englobe-o. A porção imaginária de Larrea inventada pelo narrador identifica-se, por exemplo, com aquele que ele gostaria de ser ou escrever, com a potência de seu eu ou com sua frustração: "Me había gustado escribir El tribunal del Askanischer Hof, en particular." (p. 262) A passagem reelabora o palimpsesto, a margem de esquecimento que o constitui, sob o signo da imagem de "um sonho dentro de outro sonho". O narrador passa a imaginar o que teria sido "El tribunal del Askanischer Hof' reescrito por Larrea e chega à conclusão de que tal empresa absurda teria o mesmo fracasso do Quijote de Pierre Ménard de Jorge Luis Borges. A alusão não gratuita a Borges, mestre da escrita temática da intertextualidade na literatura contemporânea, alude à impossível tarefa de imitar a totalidade textual de uma obra e da realidade. Assim, por meio da fragmentação intertextual, a narrativa postula que não há possibilidade de a intertextualidade ser identificação total entre textos e entre a dimensão fictícia e real.

Ao matar-se Larrea deixa uma obra inacabada que "versaba sobre la vida de Lord Curzon (...)" (p. 262). O narrador diz ter tido oportunidade de ler a biografia do personagem histórico escrita por Ronaldshay. A interpenetração inclusiva entre 
personagem histórico e fictício complica-se quando o narrador descreve o suicídio de Larrea, causado pela ruptura da ilusão de estar vivo. Na véspera de seu suicídio, Larrea pensa que pode

"continuar simulando que se existe, (...) como si estuviera vivo. O bien todo lo contrario: como si hubiera muerto treinta y siete años antes, como si se hubiera ido en humo. Como si su vida, desde entonces, no hubiera sido más que un sueño en el que habría soñado toda la realidad: los árboles, los libros, las mujeres, sus personajes. A menos que éstos no le hubieran soñado a él. Precisamente: a menos que Juan Larrea no me hubiera soñado a mí mismo. A menos que Juan Larrea fuera un superviviente de Buchenwald contando una parte de mi vida en un libro firmado con seudónimo: mi propio nombre." (p. 263-264)

A vida ilusória de Larrea inclui a ilusão de estar vivo do personagem-autor. Larrea, no caso, é um personagem fictício cuja parcela de realidade, seu passado em Buchenwald, expressa a "verdade" da vida de seu criador, o fato de sentir que sua vida é uma ficção. Em outras palavras, a identificação entre o narrador e Larrea é dialética. Larrea é uma ficção que exprime o real na medida em que incluiu a ilusão do narrador de estar vivo através da ilusão de Larrea de estar vivo.

A trama entre vida e arte ganha complexidade ao sabermos que Larrea havia sido um dos nomes de guerra na clandestinidade do narrador na Espanha franquista. O pseudônimo tinha sido inspirado na vida do escritor espanhol da década de vinte. $O$ narrador mudara o pseudônimo ao ser delatado. ${ }^{111}$ Jogando com a dialética entre fiç̧ão e realidade, o narrador insinua que sua suposta morte enquanto Juan Larrea na clandestinidade deu origem ao protagonista de La Montaña blanca, que se suicida em seu lugar:

"Pero Juan Larrea escapó de la policía franquista. Se suicidó, muerto en mi lugar, algunos años más tarde, en las páginas de La montaña blanca. El círculo de las vidas y de las muertes, verdaderas o supuestas, parecía cerrarse de este modo". (p. 264)

\footnotetext{
${ }^{111}$ Gerárd, o nome de guerra de Semprún quando lutou na Resistência francesa contra o nazifascismo, tornouse o nome de seu protagonista de caráter autobiográfico de sua obra El largo viaje. Federico Sánchez, seu nome de guerra na militância clandestina contra o regime franquista, deu origem a Autobiografía de Federico Sánchez, romance de forte cunho autobiográfico que se transformou em texto paradigmático, nos anos de 1970 e 1980, na Espanha, em que houve um boom de obras que testemunhavam o desencanto em relação à militância política comunista e à ideologia marxista partidária.
} 
O círculo aponta para a imagem do "sonho dentro do sonho". A dialética entre ficção e realidade no capítulo assume o motivo da invasão e inclusão entre identidades e realidades, a do campo e a de fora do campo de concentração. As duas mortes fictícias de Juan Larrea salvam o narrador como guerrilheiro e sobrevivente de Buchenwald. O poder de vida e de morte da arte revela o quanto as fronteiras entre as duas instâncias permitem uma mútua inclusão através do poder de escrever.

O último fragmento narra como o personagem-narrador soube da morte de Primo Levi, sob o leitmotiv da inclusão e invasão. A narrativa sugere que a morte de Levi despertara a consciência do personagem-narrador para sua condição mortal, ou seja, sua situação provisória e precária no mundo. Mas principalmente o fez refletir sobre a responsabilidade de portar uma memória que precisava ser testemunhada e transmitida antes que não houvesse tempo de vida para tanto.

A certa altura do fragmento, o narrador nega ter tido necessidade de conversar com Primo Levi, embora tivesse tido oportunidade. O narrador tem a sensação de existir uma impossibilidade de "diálogo de supervivientes". Esta impressão baseia-se no fato de ele sentir compartilhar plenamente o sentido da experiência com Primo Levi. A identificação total recusa o diálogo. Em La escritura o la vida, o diálogo surge de uma carência de sentido e de sua busca.

O personagem-narrador havia lido La tregua "en el patio interior" da biblioteca de los Banfi, "em otoño". O outono representa o ocaso, o declínio da vida. O "patio interior" insiste no caráter de "incluir", "abrigar", que a narrativa exprime neste capítulo. O narrador repete a informação de ter fechado os olhos ao ter lido a última página do livro de Levi. Ao fechar os olhos, ele interiorizava o significado que já estava em seu interior: "o sonho dentro do sonho da vida".

A narração da morte de Primo Levi contrapõe sua decisão de atirar-se no vazio da escadaria de seu prédio em Turim à entrada imprevista do eu de Buchenwald na escrita do personagem-narrador:

"El 11 de abril de 1987, en cualquier caso, aquel sábado durante el cual, a la vuelta de una frase, de improviso, el fantasma del joven deportado que yo había sido surgía en una novela donde no estaba previsto, (...) Primo Levi escogía la muerte tirándose por el hueco de la escalera de su casa de Turín." (p. 265) 
Primo Levi atira-se para dentro da escadaria e para fora da vida, enquanto o fantasma da testemunha do personagem-narrador surge de fora da vida, de dentro da morte de Buchenwald, e atira-se para dentro da vida através da escrita.

A coincidência paradoxal transforma a perspectiva de tempo do personagemnarrador, que situava a morte no passado e a vida no futuro, sentia-se imortal. Desde então, ele volta a colocar a morte no futuro. Ao saber da idade de Primo Levi pela notícia de sua morte no rádio, imagina restar-lhe o tempo de vida referente à diferença entre a idade em que Levi morreu e a sua. Ou seja, ele imagina ter a mesma duração de vida que Levi, mais cinco anos. O processo de identificação do personagem-narrador com Primo Levi penetra no discurso laudatório do narrador ao escritor testemunha sobrevivente de Auschwitz. Numerosas citações e considerações do narrador sobre sua obra erguem-no à altura de um paradigma, um pai-texto cujo vulto sombreia as demais obras da forma literária de testemunho. Observamos nessa empresa de referência, reverência e elucidação da obra de Levi um esforço do narrador para sair à luz. Mas as citações sempre fazem alusão ao motivo de "penetração", "interiorização" do capítulo. Por exemplo, ao comentar como Levi começa a escrever, em 1945, com "apresuramiento, con fervor, con una especie de alegría", o narrador cita a seguinte passagem ilustrativa de Los hundidos y los salvados de Levi: "'Las cosas que había vivido, padecido, me quemaban por dentro"' (p. 267). Em seguida, explica-nos que se trata de uma referência de Levi à citação que ele põe como epígrafe neste livro de um poema de Coleridge. O narrador transcreve a epígrafe de Levi. ${ }^{112}$

As diferenças e semelhanças do processo de sobrevivência e de escrita como estratégia de sobrevivência entre o personagem-autor e Primo Levi tornamse objeto de reflexão do narrador. Ao contrário de Semprún, Levi começa a escrever logo após a libertação e a escrita converte-se para ele em um estímulo de vida. Sua obra, no entanto, não tem recepção imediata. As editoras não a

\footnotetext{
${ }^{112}$ Since then, at an uncertain hour, That agony returns:

And till my ghastly tale is told

This heart within me burns.
} 
aceitam. Foi necessário que se passassem "largos años para que su libro, Si esto es un hombre obtuviera de repente una audiencia (...)" (p. 268) Para o narrador, este vácuo de surdez da indústria cultural e do público reitera o pesadelo recorrente do deportado, narrado por Primo Levi, o de voltar a casa e não ser escutado por seus familiares e amigos nem conquistar-lhes a confiança. $O$ narrador descreve essa situação reiterando a idéia de descrédito e negação da "verdade" "en el círculo familiar", no "propio entorno". Isto é, o interior, o familiar, expulsa o sobrevivente da vida ao expulsar sua narrativa testemunhal, transformando aquele pesadelo em realidade. Ao transformar o pesadelo em realidade, o real expulsa da vida real o sobrevivente que cai no círculo do "sonho dentro do sonho".

A vida e a obra de Levi servem de contraponto para a reelaboração da história e da obra do narrador. A morte de Primo Levi o faz questionar o poder mortífero da angústia das lembranças do campo:

"Fuere lo que fuese, el 11 de abril de 1987 la muerte había dado alcance a Primo Levi.

¿Por qué, cuarenta años después, sus recuerdos habían dejado de ser una riqueza? (...) ¿Por qué le había resultado imposible asumir la atrocidad de sus recuerdos?

Por última vez, sin recurso ni remedio, la angustia se había impuesto, sencillamente." (p. 269)

A morte que alcança Levi sugere a imagem de uma mão que agarra, que contém a vida, impondo-se sobre ela. Isso ocorre porque o sobrevivente não consegue mais "assumir", tomar para si, suportar a negatividade dessa imposição. Quando a imposição da angústia não encontra uma passividade que a suporte, esta se volta contra aquela de modo brutal. A idéia é de que o conflito entre força passiva e ativa no sobrevivente seja dialético: é necessária uma passividade forte que enfrente assumindo-a a força impositiva do Mal sofrido para que não haja sua autodestruição.

\subsection{A expulsão do Mal do campo à escrita}


O movimento dialético do nono capítulo do romance, "Oh estaciones, oh castillos ...", define-se pela expulsão do personagem-narrador da vida de militância e na relação desta com a memória da morte e sua escrita. Se no capítulo anterior a identidade de sobrevivente testemunha invadia a escrita do personagemnarrador, agora o narrador conta-nos como sua expulsão do PCE resulta na atividade de escritor testemunha.

A cena da entrega do prêmio Formentor conjugada com a da viagem a Praga conformam a ação representada neste capítulo do romance. Em 1964, no palácio de Salzburgo, o personagem-narrador recebe o prêmio pela publicação de El largo viaje. Durante a cerimônia de entrega, lembra-se de sua viagem, em 1956, a Praga, cidade à qual havia sido destinado como mensageiro de uma dissidência com o partido cuja conseqüência seria sua expulsão, em 1964. O momento da entrega do prêmio proporciona uma digressão aparentemente fortuita pela obra de Kafka, especialmente Cartas a Milena, comprada em Zurick, cidade de passagem na viagem que fez a Praga em 1956. A interpretação das cartas de Kafka a Milena aprofunda e amplia a reflexão do narrador sobre a relação entre a vida e a literatura, a experiência da morte em Buchenwald e a escrita.

Neste capítulo, a narrativa sofre uma fratura em sua tênue linearidade temporal ao efetuar um recuo de 1987 a 1964. Esta volta atrás visa a explicar a invasão e a inclusão do eu sobrevivente de Buchenwald na escrita do personagem-narrador em 1987. A expulsão do personagem-narrador do PCE reflete-se na invasão do passado de Buchenwald em sua vida de escritor. É como se a perda de poder enquanto dirigente político do partido comunista estivesse implicada na tomada de poder de escrever. Essa dialética é percebida no emprego recorrente neste capítulo da formulação de ter recuperado o poder da escrita e recuperado a vida em oposição ao uso freqüente no capítulo anterior da proposição de ter sido dominado pela antiga morte que se impusera em sua escrita. Contraditoriamente, a expulsão do partido comunista coloca o personagem-narrador na posição de um agente ativo, pois a partir dessa expulsão ele recupera a identidade abandonada de testemunha escritor; ao passo que o 
aparecimento do eu oriundo do campo deriva de uma ação de um outro, em relação ao qual o personagem-narrador situa-se como agente passivo.

Pensar, operação do consciente, em oposição à estratégia do inconsciente produzida em 1987, reflete a dialética que se expressa na composição desta terceira parte, a da diferenciação. O domínio sobre a narrativa é exposto por um narrador que freqüentemente deixa claro quem decidirá sobre o curso e os desvios da mesma. As associações entre a memória da morte e a escrita são estabelecidas a partir de um diálogo com o próprio leitor, no qual cabem a reflexão, a descrição, a narração e o intertexto através de trechos da obra de Kafka. O tempo da escrita e o tempo da leitura encontram-se em tensão com o tempo do mundo narrado. $O$ artifício de enfocar a realidade sob a perspectiva do personagem-narrador é desfeito amiúde aqui, o que reitera a conquista do narrador sobre as circunstâncias da matéria e sugere um momento de superação nesta espiral. Pensar, dominar, refletir e fazer-nos refletir sobre associações implícitas entre eventos retroativos e conteúdos insondáveis dão a tônica deste capítulo que assim retrata a transformação deste sobrevivente.

No entanto, este momento de superação contém sua contradição negativa. $O$ episódio da entrega do prêmio decorre de uma rememoração do narrador ao rever as fotos daquele momento. Observando uma das fotos, o narrador tenta explicar a associação que fez na ocasião da entrega do prêmio entre a jovem que aparece na foto e Milena. É a partir dessa primeira indagação que a narrativa discorre sobre outras lembranças, imagens e leituras na busca de compreender as relações entre "la memoria de la muerte y la escritura". Os episódios da viagem a Praga e a Bucareste, da leitura das cartas de Kafka, da versão em branco da tradução em espanhol de El largo viaje, da leitura de Baudelaire formam conexões ambíguas, incertas. Tais imagens, textos e fatos relacionados entre si não chegam a preencher o vazio do branco da memória, metáfora da versão em espanhol em branco do livro premiado e do que sempre fica por narrar, por descrever, evocar e refletir sobre a experiência em Buchenwald. Assim, o efeito do reflexo da primeira parte do romance reaparece transformado. A contemplação de sua imagem na fotografia representa a auto-reflexão mais distanciada, embora incapaz de 
preencher as lacunas entre a memória de Buchenwald e a escrita, de reconstruir por completo a identidade do sobrevivente testemunha escritor.

A descrição (da foto) está em tensão com a rememoração reflexiva (dos episódios e textos que a foto faz evocar). $\mathrm{O}$ jogo de planos temporais, que se dá nesta rememoração reflexiva e na fragmentação textual, representa a dificuldade de os episódios ajudarem a compreender de modo preciso a transformação do personagem-narrador. $\mathrm{O}$ eu do escritor testemunha premiado ressurge como fruto de uma reflexão crítica do militante de esquerda, que provoca sua expulsão do PCE e, por conseguinte, uma inflexão em sua história no sentido da recapitulação de sua identidade de sobrevivente do Holocausto.

Uma pergunta proveniente do presente da enunciação inicia o capítulo e constitui seu leitmotiv: "¿Por qué aquella joven me había hecho pensar en Milena?" (p. 270) Em seguida, o narrador comunica-nos que hoje, revendo as fotos da entrega do prêmio, "la similitud no parece evidente". Os anos passados não resolveram a associação feita naquele momento. É o sentido oculto, a essência oculta na aparência dessa semelhança, que será perseguido no capítulo.

A narrativa apresenta a cena principal do capítulo ao modo de um quadro, ou melhor, uma fotografia. O narrador recorre à contemplação das fotografias para descrever a cena da entrega do prêmio. A fotografia the oferece uma descrição detalhada e superficial da jovem e dos convidados à mesa de gala, pois nem todos os rostos captados pela câmera são reconhecidos por ele. Trata-se do instante captado sob o olhar do fotógrafo, que não coincide com as lembranças do narrador sobre a ocasião. As dúvidas sobre o jogo dialético de aparência e essência que a imagem comporta potencializam a dúvida inicial sobre a ligação em sua memória entre a jovem e Milena:

"El fotógrafo ha captado un instante de ligereza, de connivencia distendida, convivencial. ¿Acaso sólo estamos cubriendo las apariencias, para las necesidades de la fotografía? ¿Cómo saberlo? La apariencia sería la verdad de esta imagen, en este caso. La falsa apariencia o el parecido verdadero. Está concluyendo la cena oficial, justo antes de la entrega del premio Formentor. Todo va bien. Los editores que forman el jurado del premio no van a tardar en ponerse en pie, uno tras otro, para entregarme cada uno un ejemplar de la traducción en su lengua de El largo viaje." (p. 271) 
A narrativa interpolará entre as entregas dos exemplares traduzidos os episódios rememorados na busca de compreender como a associação estabelecida pela memória do personagem-narrador naquele momento da entrega entre a jovem e Milena poderia elucidar as relações entre "la memoria de la muerte y la escritura".

A conexão criada na mente do personagem-narrador se dera antes do momento da foto, quando a jovem cruzava o salão de cerimônia. Algo em seu andar, silhueta, porte, teria-o feito pensar na Milena Jesenskà referida nas cartas de Kafka, já que ele tinha em sua memória uma Milena criada a partir de suas leituras das cartas de Kafka. Ora, o reflexo especular da leitura aparece como outro mediador que se interpõe nesta busca de sentido complicando-a.

Antes da entrega da primeira das doze versões de El largo viaje, da versão em alemão, o narrador faz uma digressão crítica sobre o conteúdo das Cartas a Milena, citando um trecho final da segunda carta em alemão e traduzindo-o ao leitor. No trecho, Kafka afirma não lembrar de nenhum detalhe particular do rosto de Milena, apenas de sua silhueta e de sua roupa ao afastar-se entre as mesas de um café. $O$ narrador surpreende-se não com o fato de Kafka ter como impressão mais forte de Milena seu andar e presença, mas sim com o fato de que o seu amor "exigente, exclusivo" por ela nascesse deste "único indicio, esta señal nebulosa de una silueta desplazándose entre las mesas de un café." (p. 272)

Implicitamente, a narrativa faz um paralelo entre a indiferença de Kafka para com as particularidades de Milena (sua vida carnal, humana, próxima, sensível) e a relação do personagem-narrador com o movimento comunista. Ou ainda uma comparação com a indiferença do movimento comunista para com a realidade humana e concreta. Por exemplo, o amor de Kafka por Milena baseia-se no vago movimento de seu corpo:

"Un amor cuya violencia estéril se basa en el recuerdo de un cuerpo en movimiento, una imagen sin duda oscuramente trabajada por la prohibición de representación de la ley hebraica, trascendida por la arrogancia de una voluntad abstracta de seducción, de posesión espiritual." (p. 273) 
Podemos traçar paralelos entre a percepção de Kafka sobre o movimento do corpo de Milena e a percepção do partido comunista sobre a realidade concreta, entre a violência do amor de Kafka e do personagem-narrador por cada corpomovimento, entre a vontade abstrata de domínio de Kafka e a do partido comunista sobre seus respectivos objetos de desejo, ou ainda entre as formas de proibição que influenciaram essas relações. Outro sinal de comparação implícita pode ser entrevisto nas questões lançadas pelo narrador a respeito do amor de Kafka por Milena: Quem é seduzido? Quem seduz? Quem corrompe? "Quién mancilla?" Questões ambíguas, aplicáveis tanto a uma relação como a outra.

Antes da entrega do exemplar da tradução alemã de seu livro premiado, o personagem-narrador lembra-se das circunstâncias em que comprou, afoito, o livro de Kafka em Zurich. As recordações do personagem-narrador sobre Zurich são entremeadas com digressões do narrador sobre seu passado como militante clandestino e sobre a relação entre ficção e realidade. Nestas digressões, a dialética entre a fraternidade e o Mal assume um papel relevante:

\begin{abstract}
"Una especie de malestar, como una leve náusea, se apodera de mí hoy cuando invoco ese pasado. Los viajes clandestinos, la ilusión de un porvenir, el compromiso político, la fraternidad auténtica de los militantes comunistas, la moneda falsa de nuestro discurso ideológico: todo eso, que constituyó mi vida, que también habrá sido el horizonte trágico de este siglo, todo esto parece hoy harto trasnochado: vetusto e irrisorio." (p. 275)
\end{abstract}

Segundo o narrador, em 1956, ano do XX Congresso do Partido Comunista Russo, as denúncias sobre os crimes do regime soviético desencadearam a transformação que redundou na queda do muro de Berlim e na Perestroika. O narrador ainda relaciona esta mudança com a queda do regime franquista, assinalada pelas manifestações estudantis da Universidade de Madri no mesmo ano. Assim, na sua perspectiva, a luta contra os regimes ditatoriais e totalitários em nossa época engendrou uma contradição particular: ao comprometer-se na luta contra a dominação da classe operária e do ser humano, o militante engajado na utopia de um mundo livre destas formas de opressão vê-se envolvido nas redes de poder que teceram o totalitarismo de esquerda e a opressão da casta dirigente do regime comunista estalinista: 
"Así pues, la historia de este siglo ha estado marcada a sangre y fuego por la ilusión mortífera de la aventura comunista, que habrá suscitado los sentimientos más puros, los compromisos más desinteresados, los impulsos más fraternales, para acabar desembocando en el fracaso más sangriento, en la injusticia social más abyecta y opaca de la Historia." ( $p$. 276)

As contradições entre aparência e essência, entre a fraternidade e o Mal, a inocência e a culpa, a ilusão da História e a verdade fictícia, ganham mais força quando, no mesmo fragmento, o narrador comenta a nota econômica de Jean Paulhan sobre o manuscrito de El largo viaje. Trata-se da observação do responsável pela aprovação da publicação de Le grand Voyage, escrito originalmente em francês. Nesta nota transcrita pelo narrador, Paulhan resume a história do romance, elogia os diálogos do autor com seu interlocutor, "el Chico de Semur", e lamenta que este personagem morra no final da viagem de trem a Buchenwald, dando a entender que este desfecho enfraquece o poder da trama. Como resposta ao comentário de Paulhan, o narrador explica que o "chico de Semur" tinha sido inventado para fazer-Ihe companhia ao refazer "este viaje en la realidad soñada de la escritura. Sin duda para ahorrarme aquella soledad que había sido la mía, durante el viaje real de Compiègne a Buchenwald." (p. 280) E acrescenta: "la realidad suele precisar de la invención para tornarse verdadera. Es decir verosímil. Para ganarse la convicción, la emoción del lector." (p. 280)

A dialética entre ficção e história subordina-se neste capítulo ao aspecto da leitura e da interpretação do leitor, ao diálogo do narrador com o leitor através do próprio papel de leitor do narrador. Para resistir ao Mal de Buchenwald, o narrador havia criado um interlocutor, uma espécie de ouvinte e leitor que acompanha seu sofrimento solitário. De modo similar, a dialética entre o Mal e a fraternidade inclui a história do movimento comunista vista sob o ponto de vista do militante dissidente. Segundo as relações ambiguamente tecidas pelo narrador, o ato de silêncio da escrita e o ato de leitura da obra de Kafka marcam respectivamente sua entrada e saída do movimento comunista.

Das lembranças da compra de Cartas a Milena em Zurich, o personagemnarrador passa a evocar a viagem de Praga a Bucareste, feita em companhia de integrantes da cúpula do PCE, a fim de expor-Ihes a divergência de um grupo da 
direção do partido das estratégias do movimento. A ironia é um recurso bastante empregado neste episódio. A viagem é descrita como "apasionante" e ao mesmo tempo "mortalmente aburrida". O narrador menciona o luxo do trem especial romano, aludindo assim à condição de casta privilegiada dos membros dirigentes do partido. Durante a viagem, o personagem-narrador tem tempo de ler Cartas a Milena.

A ironia atinge a figuração do leitor. O narrador diz não ter tempo para realizar uma digressão sobre a viagem de Praga a Bucareste, assim como não teve tempo de fazê-la sobre Kafka há pouco. Mas será justamente uma digressão a respeito das leituras de Kafka o enfoque que iluminará a realidade comunista que the foi desvelada com sua viagem de Praga a Bucareste. Segundo o narrador, as leituras de Kafka e a leitura em geral serviram-Ihe de objeto de reflexão para compreender "las razones que me han impedido sucumbir a la estulticia comunista" e "los misterios de la vida social burocratizada". As leituras da ficção de Kafka ajudam-no a elucidar os discursos do partido, vistos pelo narrador como uma ficção, um engodo da realidade:

"Así, durante todo aquel período, las ficciones de Franz Kafka me remitían a la realidad del mundo, cuando lo real constantemente invocado en el discurso teórico o político del comunismo no era más que una ficción, apremiante sin duda, asfixiante a veces, pero cada vez más desprovista de cualquier anclaje concreto, de cualquier verdad cotidiana." (p. 283)

O Mal dos Gulags, os processos sumários dos Estados do bloco comunista, o terror instalado na luta de poder da casta burocrática de tais Estados, informações deflagradas durante o XX Congresso do Partido Russo, constituem para o narrador "la realidad kafkiana del universo estalinista". É como se a razão fria, burocrática e absurda do Mal vislumbrado pela ficção de Kafka houvesse se tornado realidade. A fiç̧ão de Kafka serviu-Ihe de lente para enxergar e justificar sua saída da organização comunista.

Entre a entrega da versão alemã do livro e a da versão em espanhol, o narrador retoma a digressão analítica sobre a relação entre Kafka e Milena. A analogia entre esta relação de amor e a relação do personagem-narrador com o movimento comunista partidário faz-se mais patente. O narrador usa qualificativos 
semelhantes para descrever os dois tipos de relação: o "amor estéril" referente ao amor de Kafka por Milena e "luchas estériles" relativas ao esforço do personagemnarrador no partido. A descrição do amor de Kafka por Milena especula sobre os danos da idealização. Trata-se de um amor destrutivo, "que se alimenta exclusivamente de la ausencia, de la distancia, de la carencia; que se dehace triste, miserablemente, a cada encuentro real, a cada instante de presencia física." (p. 285) Para o narrador, o amor de Kafka prescinde de prazer carnal, apóia-se numa "pasión desencarnada, locamente narcisista, brutalmente indiferente al otro". (p. 285) Podemos entrever nesta idealização, a "ilusión improductiva" do personagem-narrador sobre a renovação do comunismo que, para ele, "es, por esencia, por naturaleza histórica, incapaz de renovarse, imposible de reformar." ( $p$. 288) Se Kafka "ha construído el edificio literario, etéreo, espléndido y estremecedor" desse amor idealizado, que não se renova, ao contrário, o personagem-narrador constrói sua vida de escritor partindo da descrença da possibilidade de transformação do movimento comunista. Sob a perspectiva do narrador, é a leitura de Kafka que colabora para sua tomada de consciência e para o que ele chama de "cambio de vida", "ruptura radical con el pasado". O instante em que sua vida muda radicalmente é sentido como "una impresión física, de una certidumbre carnal" e identificado com o momento da entrega por Carlos Barral da versão em espanhol do romance premiado. A transformação do personagemnarrador, decorrente da reflexão sobre a teoria e a práxis política do partido, implica uma transformação subjetiva e sensível. A dialética entre o sensível e o abstrato, a práxis e a teoria, a matéria e o espírito, que inicia a narrativa de $L a$ escritura o la vida, retorna como um elemento transformado e transformador. 0 sobrevivente, que se encontrava sensivelmente assimilado ao universo concentracionário e incapaz de elaborar sua experiência, agora vê sua sensibilidade impregnar-se da mudança que dará origem à reelaboração permanente desse passado. ${ }^{113}$

\footnotetext{
${ }^{113}$ Em geral, a crítica literária sobre Jorge Semprún identifica como um dos temas freqüentes de sua obra o desencantamento com relação à práxis e à ideologia marxistas envergadas pelo PCE, durante os anos de militância política do autor no aparelho, em Madri. J. Sinnigen, por exemplo, considera que em Semprún a crítica ideológica e a prática política são atividades que colaboram para uma crítica permanente da linguagem.
} 
O episódio do veredicto da expulsão do personagem-narrador do PCE também se dá em Praga, em 1964, em um antigo castelo dos reis de Bohemia. A narrativa o sobrepõe significativamente após o ato de entrega do livro por Carlos Barral que the informa que a versão em espanhol está em branco. O personagemnarrador, imerso nas lembranças de seu último passeio por Praga, em 1964, não capta a informação. Ela Ihe escapa, passa em branco.

Nesta última viagem, em 1964, como membro do comitê central do PCE, o personagem-narrador visita a tumba de Franz Kafka e observa um quadro de Renoir, na Galeria Nacional instalada no Castelo. Trata-se do retrato de uma jovem "risueña y dorada", do qual o narrador distingue "el movimiento de su cuello, el pliegue de la tela en el hombro, la blancura de este hombro adivinado, la firme redondez del pecho por debajo de la tela." (p. 289) A descrição realça o movimento, o branco da pele, a sensualidade observada pelo receptor-narrador. Em seguida, o narrador conta que, em 1960, em uma de suas estâncias em Praga, ele imaginou que Milena pudera ter contemplado este quadro. Esta suposição reaparece nesta sua última vista do quadro, em $1964{ }^{114}$.

"Me había acordado del estremecimiento que se había apoderado de mí ante la ocurrencia de que Milena debía de haberse situado más de una vez en este mismo sitio, inmóvil, contemplando el lienzo de Renoir." (p. 289)

O estremecimento, a imobilidade, estados indicadores do Mal absoluto do campo nesta narrativa, descortinam um dado sobre a história de Milena que altera

\footnotetext{
Tomando Autobiografía de Federico Sánchez (1978) como obra paradigmática desta concepção de linguagem no escritor, o autor afirma que Semprún "Al someter el lenguaje del partido, que también ha sido el de Federico Sánchez, a una dura crítica, intenta desvelar el papel que desempeña el lenguaje en la articulación de una óptica que determina la percepción del mundo (aquí concretamente el de la política) y, por tanto, la manera de intervenir en él. Es necesario entender esta óptica y corregirla constantemente. Por eso - y por otros motivos que ya veremos - sería erróneo pensar en este libro como una crítica definitiva y/o totalizadora. Por el contrario, su cuestionamiento indica que su propio lenguaje, su propia óptica, también tendrán que ser sometidos al mismo tipo de análisis. No es un texto aislado, sino uno que forma parte de un proceso continuo de compromiso y reflexión.” In SINNIGEN, J.. Narrativa e ideología. Madrid: Nuestra Cultura, 1982, p. 50 .

${ }^{114}$ Relatos de episódios ligados a outros por um detalhe em comum que faz o narrador desviar-se da história formam uma intrincada rede narrativa que parece imitar o modo de agir descontínuo da memória. Recordações dentro de recordações, analepses de analepses, prolepses analépticas, desenham uma estrutura temporal complexa. O que esta representação do funcionamento da consciência e da memória oculta, contudo, é uma escrupulosa seleção dos eventos que se ligam segundo um movimento dialógico-dialético fragmentário.
} 
e complica as associações implícitas entre os episódios neste capítulo. Milena morre deportado em um campo de concentração:

\begin{abstract}
"Me había acordado de un recuerdo de nieve centelleando bajo la luz de los reflectores, recuerdo estremecedor que acababa de hacer que estallara como un fuego helado el recuerdo de la propia Milena: Milena Jesenskà, fallecida en el campo de concentración de Ravensbrück. Me había acordado de este recuerdo de nieve cayendo sobre las cenizas de Milena Jasenskà. Me había acordado de la belleza de Milena dispersada por el viento, con el humo del crematorio." (p. 289)
\end{abstract}

A lembrança da neve de Buchenwald desencadeia sua lembrança sobre Milena, que no texto se confunde com as lembranças de Milena. É como se a lembrança da neve de Buchenwald do personagem-narrador se comunicasse com a de Milena, que também vivenciara o frio do campo. A lembrança do sobrevivente sobre o campo cobre as referências que ele tem da personagem de Kafka assim como a neve de Buchenwald cobre as cinzas de Milena. Assim, como última evocação do campo relacionada a Praga, o narrador diz que completara o périplo de recordações de Praga lembrando-se de Claude-Edmonde Magny ao visitar o antigo cemitério judeu de Pinkas e a sinagoga vizinha:

"Casi veinte años después, me acorde de nuestra conversación, de la extensa carta que me había leído a propósito del poder de escribir. Pensé, entre las lápidas de Pinkas, que iba a recibir en Salzburgo, unas semanas más tarde, el premio Formentor otorgado a un libro del que habíamos hablado, aquel día lejano, y que había tardado casi veinte años en escribir." (p. 290)

Praga de 1956, Praga de 1960 e Praga de 1964 formam três momentos na transformação do personagem-narrador, em que estão presentes Milena, a relação com o partido comunista e a relação com as lembranças de Buchenwald através da escrita. Milena surge em 1956 sob a ótica de Cartas a Milena de Kafka, que na perspectiva do narrador distorce a "verdade" sobre a pessoa por trás da personagem. A Milena de 1960 e de 1964 reaparece mediada por outro olhar, o de Renoir, que não a retrata, mas cujo retrato de uma jovem risonha faz o personagem-narrador lembrar de Milena justamente por contrapor-se ao retrato de Kafka sobre a amante. Na descrição do retrato de Renoir, o narrador destaca como o pintor combina o movimento distante com a sensualidade próxima na representação da jovem. Mas a Milena de 1964 reaparece transformada e mais 
próxima à realidade, sobretudo porque traz consigo a experiência da morte no campo.

É a história do personagem-narrador com o partido comunista que o faz revisitar Praga, evocar as diferentes Milenas que vão se transformando à medida que o olhar do personagem-narrador vai mudando com as leituras dos diferentes "retratos" de Milena. As divergências do personagem-narrador com o partido desde 1956 vão se acirrando até sua saída em 1964. A relação entre essa expulsão e a assunção da escrita da memória de Buchenwald é causal e dialética. Não se trata de uma causalidade unívoca. 115

As relações com as lembranças de Buchenwald nestes três momentos, em 1956, 1960 e 1964, estão mediadas pelas relações com as imagens fictícias e reais de Milena que influenciam as imagens reais e fictícias do personagemnarrador sobre o movimento comunista. As relações deterioradas com o partido determinam a retomada das lembranças e da escrita da memória de Buchenwald. Poderíamos dizer que de leitor o personagem-narrador passa a assumir o papel de escritor. Ou seja, é como leitor de Kafka que ele relaciona as duas formas de totalitarismo, para então se tornar um escritor que as testemunha e denuncia. É como se a leitura das cartas de Kafka houvesse conferido o poder de escrita aludido como ausente pela carta de Claude vinte anos antes de lhe conferirem o

\footnotetext{
${ }^{115}$ Os anos de militância de Semprún no Partido Comunista Espanhol são considerados pelo mesmo como um modo de sublimação, como uma maneira de transformar-se em outro para seguir existindo. Não porque a ideologia comunista não coincidisse com seu sistema de valores e sua formação intelectual. Ao contrário, Semprún não abre mão da liberdade, da fraternidade, da solidariedade e suas críticas ao movimento comunista referiam-se a uma prática partidária que, segundo ele, justamente negava tais valores. O militante diverge da organização, da atuação e do discurso do aparelho partidário que, segundo ele, exercia um controle opressivo sobre a liberdade reflexiva de seus militantes. A rigidez da hierarquia do partido, a exclusão das opiniões dissidentes e a presença de um discurso "monológico y monolítico" apoiado no instrumental teórico da dialética marxista são apontados como motivos da desilusão de uma geração de militantes com relação à práxis histórica revolucionária comunista. O conhecimento da existência dos Gulags e dos crimes cometidos pelo Estado comunista soviético vai ao encontro de sua desilusão com o movimento. Mas continuar a luta contra as formas de opressão e dominação no mundo como intelectual e escritor engajado não significava uma simples alternativa. Se a rememoração através da escrita constituía o plano em que se travaria agora essa luta ideológica contra o esquecimento sistemático dos massacres cometidos pela ordem capitalista e pela via soviética, a escrita envolvia também um novo impasse intransponível: recuperar o eu cindido na experiência de Buchenwald que o ameaçava permanentemente com a possibilidade de auto-aniquilamento. A negatividade da experiência vivenciada em Buchenwald manifesta-se na cisão que ela operou no eu do sobrevivente de tal maneira que a vocação literária e a identidade de sobrevivente tornaram-se indissociáveis. A interpenetração entre arte e verdade, literatura e história, ficção e realidade, conforme é sentida por Semprún, não permitia uma escolha identitária excludente entre ser escritor e assumir sua condição de sobrevivente de Buchenwald.
} 
prêmio. É como se a exegese do escritor referida por Claude, em sua carta dirigida ao interlocutor e leitor Semprún, como condição do processo criativo se desse para ele somente depois de uma exegese do leitor. Os elos desta transformação são rastreados pela narrativa.

O capítulo conclui com o momento da entrega da versão em branco de $E I$ largo viaje. A idéia de diferenciação, de transformação, faz-se patente no sentido que se desvela neste ato e em outros a ele associados. Carlos Barral explica ao personagem-narrador "la singularidad del libro que sostiene en la mano". Como a publicação de seu livro na Espanha franquista havia sido censurada, Barral imprimiu o livro no México. No entanto, a impressão não estava ainda pronta e para cumprir com o protocolo da cerimônia, Barral havia encomendado um exemplar que possuía o formato, a encadernação, o número de páginas, enfim, era idêntico ao modelo que seria impresso, exceto pelo conteúdo das páginas que estavam em branco. A entrega do exemplar espanhol em branco constitui uma revelação para o personagem-narrador: "El momento único que pensaba que había fallado, cuyo significado me creía incapaz de captar, que se me había escurrido entre los dedos como água, la arena, el humo, recupera su espesor, su densidad tornasolada." (p. 291) Em seguida, o narrador remonta ao $1^{\circ}$ de maio de 1945, à tormenta de neve caindo sobre as bandeiras do desfile quando os deportados chegavam à Place de la Nation. E afirma que aquela "nieve de antaño" voltara a cair sobre sua vida, apagando as marcas impressas do livro iniciado num apartamento em Madri, como clandestino, numa noite em que sonhara com a neve de Buchenwald. Mas neste momento a narrativa aponta a mudança que o retorno da neve significa relacionando-a com o poder de apagar, sepultar o passado traumático sob seu branco: "La nieve de antaño recubría las páginas de mi libro, las sepultaba, en una mortaja algodonosa. La nieve borraba mi libro, por lo menos en su versión española." (p. 291-292)) O sepultamento camuflado, agora mostra-se realizado de modo distinto. A conseqüência porém não corresponde a um luto definitivamente acabado. O poder de cobrir e apagar é provisório e dialético. A ação de apagar a escrita da memória do branco da neve 
requer a reinscrição desta memória, ou seja, sua reescrita, para que o branco da memória da neve não apague a vida do sobrevivente escritor:

"El signo no era difícil de interpretar, no costaba sacar la lección: nada era definitivo todavía. Este libro, que había tardado veinte años en poder escribir, se desvanecía de nuevo, apenas concluido. Tendría que empezarlo otra vez: una tarea interminable, sin duda, la de transcribir la experiencia de la muerte." (p. 292)

Que fosse a língua materna a que trouxesse esse sinal lhe parecia bastante significativo. O narrador discorre sobre a escolha do francês como sua nova língua originária, concluindo ser ela para ele a antítese da noção oficial de pátria e origem; defende que o francês, contraditoriamente, torna-se sua língua materna na medida em que é sua língua do exílio, já que "había hecho del exilio una patria". Aqui, o tema dialético da pátria e do exílio está condicionado ao sentido da transformação. O narrador ainda aborda a origem traída com o fato de poder reescrever o próprio livro em espanhol, prescindindo da tradução existente, traindo assim duplamente sua forma original em francês e a traduzida. Numa conversa, anos depois com Carlos Fuentes, em um café parisiense, Fuentes comenta:

“_Además - añadió -, deberías haber hecho tú mismo la versión española. No te habrías limitado a traducir, te podrías haber permitido traicionarte. Traicionar tu texto original para tratar de ir más lejos. Con ello habría surgido un libro diferente, del cual podrías haber hecho una nueva versión francesa, jun nuevo libro! Como dices tú mismo, esta experiencia es inagotable..." (p. 294)

O princípio da tradução retorna ao livro, submetido ao sentido da diferenciação do eu do sobrevivente. A tradução-traição comporta um elemento transformador da ficção e da realidade. O novo implica uma traição ao velho, à origem. Foi somente burlando a identidade de sobrevivente através do exercício da militância e logo "traindo" as diretrizes do partido que as lembranças de Buchenwald puderam ser apaziguadas e ressurgirem transformadas. Além disso, a narrativa faz menção a César Vallejo, ao "dia de aguaceros parisinos de primavera, como en un poema de César Vallejo"116, em que Carlos Fuentes e o

\footnotetext{
${ }^{116}$ Trata-se de uma citação implícita dos versos de César Vallejo, poeta peruano refugiado na França, que continuou escrevendo em castelhano:

Piedra negra sobre una piedra blanca

"Me moriré en París con aguacero,
} 
personagem-narrador conversavam e riam sobre a reescrita de El largo viaje. A poesia de Vallejo serve para expressar a impossibilidade do luto da memória de Buchenwald agora através de sua renovação contínua. A primavera simboliza essa idéia.

O narrador termina o capítulo propondo-se rechear as páginas em branco do exemplar espanhol que ainda guardava com "la historia de Jerzy Zweig, un niño judío de Buchenwald", para Cécilia Landman. Ele costumava recitar "Le voyage" de Baudelaire a Cécilia quando tinha três anos, mas evitava a estrofe que havia recitado a Maurice Halbwachs. A estrofe silenciada na recitação, contudo, fôra capaz de efetuar uma transformação da lembrança do Mal de Buchenwald no sobrevivente:

"Los versos de Baudelaire habían constituido para Halbwachs una
especie de oración de moribundos. Una sonrisa se había esbozado en
sus labios al oírlos. Pero tenía a Cécilia entre mis brazos, le recitaba
Baudelaire y el recuerdo se desvanecía. Se transformaba, mejor dicho.
La pestilencia, la injusticia, el horror de la muerte antigua se borraban,
quedaba la compasión, un sentimiento agudo, estremecedor, de
fraternidad." (p. 295)

A lacuna dos versos de Baudelaire produz um processo de transformação em que o tormento das lembranças dá lugar à paz do esquecimento que por sua vez se transforma em uma lembrança apaziguada. É necessário observar que tanto a fraternidade já estava presente e unida ao horror desta morte compartilhada como a transformação não implica que o Mal tenha sido eliminado, configurando, portanto, uma transformação dialética.

A história de Jerzy Zweig é uma história de um menino judeu salvo e que o narrador reencontra em Viena, “años más tarde, en otra vida: la vida.” (p. 296) Tanto Cécilia quanto Jerzy são agora jovens judeus, filhos de uma geração de sobreviventes do Holocausto. A lembrança de trazer nos braços e de reencontrar a nova geração originária da catástrofe parece não só apaziguar as lembranças da testemunha como também incitá-lo a dar testemunho da experiência da qual eles são fruto e possuem uma lembrança bastante desvanecida, apagada. Ora, a 
reescrita inscreve-se na vida como modo de salvar a memória da experiência da morte. A história da criança salva seria contada como se fossem cartas a Cecília.

A existência é concebida como um ciclo entre vida e morte, que se refaz e se renova como as estações, apresentando a cada vez, a cada volta, transformações múltiplas e dialéticas. Os encontros nos castelos configuram uma contradição do ciclo transformador das estações. Temos o Castelo dos reis de Bohemia, onde houve a reunião da direção do PCE que sancionou sua expulsão do partido; temos o Castelo que abriga o acervo pictórico da Galeria Nacional de Artes de Praga, onde se encontra o quadro de Renoir; e o Castelo de Salzburgo, lugar da cerimônia do prêmio Formentor. O castelo - símbolo aristocrático de uma classe social que mantinha seu status quo graças à conservação de um poder econômico e uma ordem social, baseados em valores sacralizados, na hierarquia social e no poder soberano -, apresenta-se nos três momentos significativos da transformação do personagem-narrador. Seu sentido é dialético: testemunha a transformação do personagem-narrador frente ao conservadorismo das instituições sociais, como a instituição partidária do PCE. No caso da reunião do PCE, o narrador ironiza o uso do castelo como o lugar onde sua expulsão foi sancionada.

\subsection{O encontro: a busca incessante do sentido da identidade e da identidade do sentido}

A ação narrada no décimo capítulo representa o encontro do personagemnarrador com o eu que chegou ao campo de concentração, em 1944, através de sua visita, em 1992, a Weimar e a Buchenwald. A convite de uma rede televisiva que faria um programa sobre Weimar, cujo tema era "Weimar, ciudad de cultura y de campo de concentración", o personagem-narrador retorna a Buchenwald. Nessa visita ocorre uma revelação que transforma sua visão sobre a sobrevivência e, conseqüentemente, sobre sua própria identidade e o Holocausto, transformando assim a concepção do próprio romance que vinha escrevendo, $L a$ escritura o la muerte. O personagem-narrador descobre que a profissão registrada em sua ficha de entrada em Buchenwald fora alterada em seu benefício pelo 
prisioneiro veterano comunista que o registrara. Ao invés de estudante de filosofia, o companheiro de campo o havia fichado como "estucador", rebocador de parede, o que provavelmente aumentara suas possibilidades de sobrevivência. Esta descoberta muda a acepção que fazia da sobrevivência. Antes, ele pensava que a sobrevivência se devia em parte a determinantes objetivos, como chegar ao campo bem de saúde e falar alemão, e a fatores imponderáveis como a sorte. Nesta dialética entre causalidade e casualidade, entre intecionalidade/moral e acaso, o ato moral e intencional da fraternidade nada ou pouco contava para a vida. A fraternidade somente participava da experiência do Mal, da morte compartilhada como um pedaço de pão. ${ }^{117} \mathrm{~A}$ idéia de que a essência da experiência do campo, a vivência da morte, poderia ser pensada a partir da dialética entre fraternidade e Mal relacionada com a dialética entre liberdade e necessidade parecia frustrar-se ante essa constatação. O campo apresentava-se como o reino da necessidade, dos instintos de sobrevivência, em que a liberdade de ser solidário não tinha espaço. Com a descoberta do ato solidário tradutório do prisioneiro comunista, a relação dialética entre o Mal absoluto e a fraternidade sob a égide da liberdade humana, e não somente da necessidade, que determinasse também a vida e não somente a morte, podia ser reafirmada como concepção da experiência. Esta concepção materializa-se na ação narrativa deste capítulo do romance, em sua resolução. A descoberta configura uma anagnoris cujo sentido representa tal concepção. $\mathrm{O}$ ato tradutório constitui o elemento solidário diferencial

\footnotetext{
117 Este trecho do primeiro capítulo do romance expressa esta idéia: "Semana tras semana había yo contemplado cómo surgía, cómo florecía en sus ojos el aura oscura de la muerte. Compartíamos eso, esa certeza, como un mendrugo de pan. Compartíamos esa muerte que crecía, ensombreciendo su mirada, como un mendrugo de pan: signo de fraternidad. Como se comparte la vida que a uno le queda. La muerte, un mendrugo de pan, una especie de fraternidad. Nos concernía a todos, era la sustancia de nuestras relaciones. No éramos otra cosa más que eso, nada más - nada menos, tampoco - que esa muerte que crecía. La única diferencia entre nosotros era el tiempo que nos separaba de ella, la distancia todavía por recorrer." (p. 30) A imagem da "aura escura da morte que florescia nos olhos de Halbwachs" é composta por um oxímoron - a aura, emissão luminosa ao redor de um corpo, antagoniza com escura - e por uma catacrese - a morte não floresce senão murcha. A morte comparada a um "mendrugo de pan" também representa certa impropriedade do sentido: o pão, símbolo do alimento da vida, aqui alimenta o ser para a morte. Na frase "la muerte, un mendrugo de pan, una especie de fraternidad", não temos mais a formulação modal da "morte que alimenta o homem como um pedaço de pão compartilhado fraternalmente". A fórmula reduz-se a "morte = pedaço de pão = fraternidade". A proposição final leva o processo de equivalências consecutivas ao paroxismo: morte $=$ pedaço de pão $=$ fraternidade $=$ substância das relações $=$ ser. Em última instância, o ser é reduzido à morte. Para o narrador, o homem, no campo de concentração, relacionava-se através da morte com o outro, com o mundo e consigo mesmo.
} 
que explica a dialética entre Mal e fraternidade, cujo conhecimento e compreensão levam o personagem-narrador a reinterpretar sua história e identidade enquanto narrador.

A descoberta dá-se através de um curto diálogo encenado com um funcionário de Buchenwald que havia se tornado um monumento memorial oficial. O personagem-narrador visita o campo em companhia do jornalista da rede de televisão e sua esposa, dos jovens Thomas e Mathieu e do funcionário. Ao saber de sua visita, o funcionário havia buscado os documentos que restavam do exprisioneiro nos arquivos do memorial. Durante a visita, quando o sobrevivente conta-lhes a noite da chegada ao campo, o funcionário interrompe-o, corrigindo a informação de que havia sido registrado como estudante de filosofia. Mas a relação dialógica colocada na cena central do capítulo dá-se de fato entre o eu da testemunha escritor e o eu do sobrevivente de vinte anos que vivenciou, cheio de curiosidade e esperança, a barbárie. $O$ diálogo com o novo funcionário é a aparência deste encontro dialógico. O processo de diferenciação da identidade do personagem-narrador deriva da identificação com o eu passado, mas também é fruto de um estranhamento com aquela identidade. $O$ encontro com o eu passado deixa-o estupefato. O estranhamento referente à sua própria história, à sua cegueira pavorosa de sobrevivente do Holocausto, retoma o processo de cisão e formação de identidades e desdobramentos do eu que remetem ao próprio início da narrativa.

O diálogo com o jovem de vinte anos deportado a Buchenwald só pôde ocorrer devido à reinterpretação de um sonho recorrente do campo, que reaparece diferenciado. A princípio, o personagem-narrador nega o convite para falar sobre sua experiência em Weimar. Na mesma noite, tem um sonho com o campo, que o faz mudar de idéia. O velho sonho obsessivo com a voz do comando "Crematório, apaguem!" - transforma-se em um novo sonho com a voz de Zarah Leander cantando canções de amor, aos domingos, pelo megafone de Buchenwald. Com uma nova interpretação desse novo sonho, ele volta atrás e resolve dar a entrevista à rede televisiva. Ou seja, uma mudança na sua relação subjetiva com a memória do Mal do campo através do sonho propicia uma 
mudança na sua relação com a realidade presente e a aquisição de um conhecimento que, por sua vez, transforma sua compreensão do passado. Esta última transformação, por sua vez, ocasiona a transformação do projeto de escrita dessa memória, objetivado no enredo desse romance. Vemos assim como a dialética entre sonho e realidade e a dialética entre ignorância e conhecimento também participam da mudança da identidade do protagonista.

Por outro lado, o mundo exterior não só o recebe como o chama para dar um testemunho que traduza sua experiência. Na perspectiva do narrador, uma certa transformação do mundo possibilita que sua interpretação da experiência se transforme. Essa transformação diferenciadora realiza-se mediante a assunção da negatividade traumática do retorno ao seu lugar de origem que, por sua vez, colocará em risco a sobrevivência de sua identidade.

A narrativa estabelece outros diálogos com personagens e questões fundamentais nesse processo dialético de busca de sentido e identidade. $O$ tenente Rosenfeld, Claude-Edmonde Magny, personagens e autores da literatura universal e da literatura de testemunho, entre outros, desempenham o papel de interlocutores dessa transformação.

O diálogo com o eu passado abrange a narração, a descrição, a evocação lírica e a reflexão, sendo que esta última não se dissocia da evocação lírica, como se a síntese entre ambas houvesse sido alcançada. No entanto, todas estas formas discursivas mobilizadas no capítulo são excluídas do diálogo com o funcionário de Buchenwald.

A cena central do diálogo com o funcionário do campo configura um quadro caracterizado por alguns elementos significativos. A frase inicial do capítulo é do interlocutor, o funcionário de Buchenwald, e corresponde a uma negativa taxativa: “_ ¡No, no es eso lo que escribió!” (p. 297) A frase é dita num tom firme, mas "casi en voz baja". O narrador descreve-a como uma verdade enunciada sob uma forma negativa que não precisa ser dita num tom contundente para afirmar-se. A dialética negativa objetiva-se na frase reveladora da ação. Logo o narrador descreve o homem que a proferiu: uns quarenta anos, olhar atento e discreto, lacônico. A reação entre os presentes, o personagem-narrador, o jornalista e 
Thomas e Mathieu Landman, é de "asombro". O narrador ainda nos informa que a conversação ocorre em alemão.

Temos aqui o espanto do olhar reflexivo do primeiro capítulo de certa maneira invertido: o novo homem do campo, o funcionário do memorial de Buchenwald, é quem provoca o assombro no personagem-narrador e em seus acompanhantes. O quadro, como os demais do romance, guarda uma grande força descritiva. Nela a narrativa desenvolve a polissemia da guerra e da paz. A informação do funcionário, por exemplo, é dita "bajo el fuego cruzado de (sus) miradas de asombro". (p. 297) O elemento da tradução da cena ressurge como fortuita nota explicativa do narrador. Mas é o ato tradutório de escrita da profissão que constitui o leitmotiv principal do capítulo, embora apareçam outros já empregados no romance como o reflexo e o eco.

No andamento do romance, o narrador interpreta as razões de seu retorno a Buchenwald. O sonho com a voz de Zarah Leander no lugar do pesadelo com a ordem "Krematorium, ausmachen!", ao dia seguinte do convite, constitui a primeira. Um sonho "fácil de descifrar". Este motivo articula-se com a conclusão do livro que escrevia, L'ecriture ou la mort. Segundo o narrador, "a través de este rodeo", ele se impunha a ordem de concluir um livro nascido em 1987 e abandonado por ocasião de sua função de Ministro da Cultura de Felipe González e para escrever Federico Sánchez se despide de ustedes. A negativa do convite transforma-se em assertiva através da transformação do sonho e de sua decifração. A ação de imposição do eu esquecido de Buchenwald, fundamental no oitavo capítulo, retorna como auto-imposição advinda de uma aceitação. O movimento de idas e voltas da práxis política institucional à práxis ideológica de escritor intelectual participa dos motivos. Outros motivos são apresentados pelo narrador como as mensagens de bom augúrio. O encontro casual com Dany Cohn-Bendit, nascido em abril de 1945: "Su vida se inició cuando la mía se reinició". Além disso, Dany nascera em Montauban, cidade cujo prefeito de esquerda amparou muitos estrangeiros refugiados de Pétain, cidade também onde morrera Manuel Azaña, último presidente da República na Espanha e "uno de los escritores más importantes del siglo xx". Para o narrador, todos esses sinais da 
luta da vida contra a morte asseveravam seu retorno a Buchenwald. Bastava saber lê-los.

A propósito da escolha de seus acompanhantes, Thomas e Mathieu Landman, seus netos do coração, o narrador discorre sobre o termo em francês para designar "vivencia", "erlebnis" em alemão. A narrativa entrelaça a escolha dos acompanhantes com a da palavra para interpretar o Holocausto. O narrador diz ter escolhido os jovens por sentir que com eles podia "evocar la experiencia de antaño, la vivencia de aquella antigua muerte, sin tener una impresión de indecencia o de fracaso." (p. 300) O termo em francês le vécu de la mort pareceIhe insuficiente, uma expressão fracassa na tradução da idéia, que para ele é ativa, posto que resulta de "las experiencias de la vida". ${ }^{118}$ Aqui a escolha da testemunha do testemunho, a passagem da história como experiência e conhecimento, articula-se com a idéia de escolha de palavras para comunicá-la. A tradução enquanto escolha de passagem de conhecimento e experiência requer o ato interpretativo que é fundamentalmente consciente e ativo.

Em seguida, a narrativa reconstitui o retorno do personagem-narrador a Weimar. O narrador descreve sua entrada "en el territorio de la antigua muerte" acompanhado de um mal-estar difuso que se esclarece quando ele se dá conta de que seu desassossego se devia ao reconhecimento dos nomes de cidades que alojaram os Kommandos exteriores de Buchenwald. O caminho de volta esboçase como uma nova descida aos Infernos. No decorrer dos caminhos deste inferno revisitado, sensações opostas encontram-se: a tranqüilidade alterna com o malestar, a familiaridade com o estranhamento; as antigas lembranças e o vivido contrapõem-se ao que é visto. A lembrança do tenente Rosenfeld surge na memória do personagem-narrador que, então, decide refazer o romance $L a$ escritura o la vida reintroduzindo o personagem Rosenfeld. O encontro com o jovem de vinte anos é descrito como uma "oscura finalidad de este retorno a Weimar" que lhe permitiria assumir a escrita:

\footnotetext{
${ }^{118}$ Valeria De Marco observa que na busca por constituir um ponto de vista que, trabalhando sobre a matéria da vivência, possa superá-la, possa "construir un texto que sea mediador del conocimiento", a narrativa "supone distinguir entre los conceptos de vivencia y experiencia, especialmente importantes en la discusión de la producción literaria que tiene como materia la barbarie." In DE MARCO, Valeria. "La escritura o la vida: la imposibilidad de ver", texto mimeografado, 2001, p. 15.
} 
"Tenía que permitirme recobrar fugazmente la fuerza de mis veinte años, su energía, su voluntad de vivir. Así, sin duda, tal vez reencontrándome, encontraría la fuerza, la energía, la voluntad de llegar hasta el final de esta escritura que se escurría sin cesar y que me rehuía. O mejor dicho: de la que yo me escurría sin cesar, y rehuía a la mínima ocasión." ( $p$. 303)

O processo de diferenciação engendra e é fruto da identificação entre o eu presente e o eu passado. Segundo o narrador, o sobrevivente ressuscita o fantasma de Rosenfeld, os fantasmas do passado, para fazerem-lhe companhia nesta descida, ao lado dos novos acompanhantes, futuras testemunhas. $O$ passado e o futuro encontram-se no presente. Assim, o personagem-narrador cruza "el umbral del Hotel Elephant".

Os personagens livrescos também o acompanham. O narrador faz uma longa digressão sobre os três livros escolhidos "para este viaje". A escolha destes hierofantes iniciáticos virtuais e reais revela um caráter casuístico, inconsciente, passivo. A narrativa vai compondo uma nova viagem iniciática cujos elementos opostos da consciência e do inconsciente, da intencionalidade e do acaso, interagem no processo de transformação da identidade. Desta maneira, o narrador informa-nos que Charlotte à Weimar de Thomas Mann, seu primeiro livro escolhido, havia sido o primeiro livro comprado depois de seu regresso de Buchenwald. Encontrou-o em sua biblioteca junto aos livros que tratavam de Buchenwald, "como si una oscura premonición (le) hubiera inducido a incluirlo en este contexto, que se revelaba legible tantos años más tarde". (p. 304) Aqui, a narrativa relaciona o "encontro" do livro a um tipo de casualidade, um escuro sinal que deveria ser decodificado, traduzido. A notação de o "primeiro livro" escolhido ser o primeiro livro comprado depois da libertação recai sobre a idéia de Origem que participa tanto do ritual de iniciação como da atividade de tradução. Ademais, o motivo da escolha do livro remete à dialética entre ficção e realidade:

"Por Thomas Mann, un poco. Por Weimar, principalmente. Sabía que la Carlota en cuestión era la de Goethe, la del Werther de Johann Wolfgang von Goethe, y éste había sido un personaje de mi vida en Buchenwald. Por sus paseos por el Ettersberg con Eckermann y por León Blum." (p. 304) 
Vemos primeiramente a intertextualidade entre as obras de Mann e Goethe, tratado, por sua vez, ironicamente como um personagem da vida do personagemnarrador em Buchenwald. A ironia reside no fato de León Blum, prisioneiro judeu de Buchenwald, haver escrito uma obra sobre as conversas de Eckermann com o escritor alemão durante seus passeios pelo Ettersberg, registradas por Eckermann. ${ }^{119}$ Há uma remissão alternada da ficção à realidade, desta àquela, num movimento em que as duas dimensões se interpenetram continuamente. Ettersberg torna-se o ponto de encontro ironicamente trágico entre esses dois universos, o da civilização e o da barbárie. Isto de certa maneira é sugerido por uma nova "estranha coincidência": Carlota Kestner, não a personagem de Thomas Man que se refere à personagem de Werther, mas a pessoa, havia se hospedado no Hotel Elephant, em Weimar: "Pero no sabía, al comprar la novela, que el hotel de Weimar donde iba a alojarse Carlota Kestner, de soltera Buff, de Hannover, la Lotte de Werther, era el Hotel Elephant. No lo sabía, pero el detalle ha quedado grabado en mi memoria." (p. 304)

O segundo livro escolhido tratava-se da correspondência entre Martin Heidegger e Karl Jaspers, de 1920 a 1963, publicada por Klostermann e Piper. O narrador não nos dá o título do livro e discorre sobre as relações entre essa correspondência e o terceiro livro, um volume de poemas de Paul Celan. O silêncio estabelece o diálogo entre as duas obras. O silêncio de Heidegger sobre a culpabilidade alemã é registrado tanto na correspondência de Jaspers com Heidegger quanto no poema "Todtnauberg" de Paul Celan. ${ }^{120}$ Os trechos do poema transcritos no original, em alemão, intercalam-se às reflexões do narrador

\footnotetext{
${ }^{119}$ Johann Peter Eckermann (1792-1854) foi um poeta alemão e amigo de Goethe. Eckermann é lembrado por sua contribuição para a divulgação da obra de Goethe através de seu livro Gespräche mit Goethe (1836-1848).

${ }^{120}$ Este é o trecho transcrito do poema de Paul Celan por Semprún:

Todtnauberg

"...die in das Buch

- wessen Namen nahms auf

vor dem meinen? -

die in dies Buch

geschriebene Zeile von

einer Hoffnung, heute,

auf eines Denkenden

kommendes

Wort

im Herzen, ..."
} 
a respeito do silêncio do Mal do Holocausto. O poema de Paul Celan é considerado pelo narrador como "un rastro hermético", "estremecedor", que registra o desaparecimento da esperança do poeta de ouvir uma palavra que saísse do coração do filósofo sobre o papel da Alemanha e de sua responsabilidade sobre o genocídio cometido. Perda de esperança que resulta, segundo deixa entender o narrador, no suicídio, na perda da vida de Celan. Assim, as obras de Jaspers e Celan atuam como "el reflejo negativo, la huella en bajorrelieve" desta opinião silenciada de Heidegger sobre a culpa alemã. Ao contrário do segundo capítulo do romance, aqui o silêncio da culpa alemã enquanto uma das vozes deste Mal agora é capaz de dialogar graças à elaboração que testemunhas da catástrofe como Paul Celan realizam através da interlocução com a voz do silêncio. Assim, reaparece o conceito de tradução como perdas e rastros de um original que manifesta sua sobrevivência nestes próprios rastros. O que não é dito por Heidegger fala através da tradução do silêncio feita por quem nele se perdeu. A voz culposa do Mal deixa suas marcas negativas por meio de seu silêncio.

O narrador ainda ressalta a contradição da sociedade alemã, representada por Weimar, cidade de apogeu cultural e de campo de concentração do totalitarismo nazista e bolchevista, de alto grau civilizatório e extrema barbárie. $\mathrm{Na}$ sua opinião, a cidade é expressão de uma sociedade cuja língua tanto traduz o pensamento de grandes intelectuais e escritores quanto emite a voz "de mando y de ladrido S.S.". Ou seja, uma língua tanto da liberdade positiva quanto negativa, uma língua da "subversión, por lo tanto de afirmación universal de la razón crítica" e da opressão e submissão às forças irracionais e instintivas de destruição. ${ }^{121}$

\footnotetext{
${ }^{121}$ Raúl Illescas entende que a língua alemã em La escritura o la vida traduz "una tensión manifiesta. Es en principio la lengua de la filosofia. La de las referencias filosóficas y de la poesia. Nietszche, Wittgenstein, Paul Celan (...) entre otros. Es la voz dorada de Zarah Leander interpretando canciones de amor, a través de los altoparlantes de Buchenwald. Y son las conversaciones con el teniente Rosenfeld durante la visita a Weimar. Pero el alemán es también el idioma del nazismo sintetizado en esa frase imperativa que el narrador repite a lo largo del relato: Krematorium, ausmachen!” Há de fato uma relação ambivalente deste intelectual com o alemão, pois ele o considera a língua de sua formação intelectual e filosófica. Este capítulo aborda essa relação ambígua do escritor com a língua e cultura alemãs através de sua apreciação crítica de Heidegger, de Brecht e inclusive do tenente Rosenfeld. In ILLESCAS, Raúl. "Jorge Semprún: La escritura o la vida. Holocausto y literatura" in LEMER, Isaías (ed.) NIVAL, Robert (ed.) ALONSO, Alejandro (ed.) Actas del XIV Congreso de la Asociación Internacional de Hispanistas, III: Literatura española, siglos XVIII - XX. Newark, DE: Cuesta, 2004, p. 321.
} 
A narração da chegada do personagem-narrador e seus acompanhantes ao campo de Buchenwald evoca os signos emblemáticos da experiência intercalando-os à descrição da paisagem atual. Assim, "el viento de antaño, de siempre" sobre "la eternidad del Ettersberg", a morte de Maurice Halbwachs e de Diego Morales são evocados como rememoração do personagem-narrador neste momento. O retorno é narrado como uma volta ao lar:

"No puedo decir que estuviera emocionado, el término es demasiado débil. Supe que volvía a casa. No era la esperanza lo que tenía que abandonar, en la puerta de este infierno, sino todo lo contrario. Abandonaba mi vejez, mis decepciones, los fracasos y los errores de la vida. Volvía a casa, quiero decir al mundo de mis veinte años: a sus iras, a sus pasiones, a su curiosidad, a sus risas. A su esperanza, sobre todo. Abandonaba todas las desesperaciones mortales de una vida, para recobrar la esperanza de mis veinte años que la muerte había arrinconado." (p. 311)

A transformação de sua identidade é descrita como uma metamorfose: é necessário despir-se da casca velha, cheia de decepções, fracassos e erros, para que o novo ser, o jovem de vinte anos, cheio de paixões, curiosidade, iras e esperança, saísse do casulo da morte.

O testemunho também é descrito como um ritual de passagem: "Apoyé la mano en el hombro de Thomas, como si le pasara el testigo." (p. 311) Para o narrador, a necessidade de se transmitir o testemunho dessa experiência baseiase no desaparecimento breve da "memoria carnal" junto com a morte da geração dos sobreviventes testemunhas. As marcas indeléveis da experiência deixadas nos sentidos e no corpo morreriam com eles. Somente a tradução abstrata dessas marcas deixadas nos livros seria capaz de transmiti-las. O abstrato opõe-se ao concreto assim como o fictício ao real. Essa dialética é reiterada pela voz de Juan Larrea, rememorado pelo personagem-narrador neste momento para transmitirnos aquilo que the confere a singularidade desta identidade:

"Un día le había hecho pronunciar a Juan Larrea, un personaje de novela que, en La montaña blanca, había muerto en mi lugar, las palabras siguientes: 'He pensado que mi recuerdo más personal, el menos compartido... el que me hace ser lo que soy... el que me distingue de los demás, al menos, de todos los demás...que me separa incluso, sin dejar de identificarme, de la especie humana... con la excepción de unos cuantos centenares... que arde en mi memoria con una llama de horror y de abyección... de orgullo también... es el recuerdo vivo, nauseabundo, 
del olor del horno crematorio: insulso, repugnante... el olor a carne quemada sobre la colina del Ettersberg..."' (p. 312)

A singularidade da identidade reside na lembrança da abjeção real, uma lembrança dos sentidos, transferível através de seu caráter intransferível. Mas esta abjeção é objeto também de orgulho e de identificação com a espécie humana. Juan Larrea, um personagem romanesco do personagem-narrador, transmite-nos o intransferível, a realidade do Mal que define sua singularidade, através da ficção da memória deste Mal real.

A rememoração da morte de Diego Morales leva-o a lembrar-se de César Vallejo e da carta de Claude-Edmonde Magny. Um novo conteúdo da carta é evocado: "'Diría de buen grado: Nadie puede escribir si no tiene el corazón puro, es decir, si no está suficientemente desapegado de sí mismo..." (p. 314) O narrador analiza o texto da seguinte maneira:

"la escritura, si pretende ser algo más que un juego, o un envite, no es más que una dilatada, interminable labor de ascesis, una forma de desapegarse de uno mismo asumiéndose: volviéndose uno mismo porque se ha reconocido, se ha dado a luz al otro que se es siempre." ( $p$. 314)

A análise recai no sentido do processo dialético de diferenciação da identidade enquanto uma metamorfose. O ser se desapega de si para tornar-se outro. Mas essa negação e abandono do que se é deve ocorrer com a assunção do que é negado. O reconhecimento do não-idêntico à identidade é o que lhe outorga a identidade. Ou seja, é através da negação do que se é que se chega a ser o que se é, algo sempre diferente para ser o mesmo. A escrita torna-se a atividade em que este processo de transformação do ser se manifesta como uma reescrita de si contínua, pois interminável.

O coração puro remete a este desapego de si, a este olhar em silêncio para dentro e para trás, a esta volta à origem assumindo o que foi negado na transformação para que uma nova transformação ocorra e o mesmo ressurja como diferente:

“¿Tenía el corazón puro ahora? ¿Me había desapegado lo suficiente de mí mismo? Esa es la impresión que tuve en aquel momento. Toda mi vida se me había vuelto transparente, en una especie de vértigo bienaventurado. Aquí había tenido veinte años, aquí se cumplía mi vida, 
a través de este retorno a la época en que solo había sido futuro." ( $p$. 315)

Em seguida, o personagem-narrador ouve "el murmullo de los cantos de los pájaros". A revelação da renovação do ser é acompanhada pelo reconhecimento da renovação da vida: "Después de todo, habían acabado por volver al Ettersberg. El susurro de sus cantos me rodeaba como un rumor oceánico. La vida había vuelto a la colina del Ettersberg." (p. 315)

$\mathrm{Na}$ seqüência, o narrador conclui a cena com o funcionário. A ficha é transcrita no fragmento e enquanto o personagem-narrador contempla-a, o narrador discorre sobre as possíveis conseqüências de haver sido inscrito como estudante de filosofia. Teria ido a Dora, uma fábrica subterrânea de foguetes, "una obra infernal, donde el trabajo agotador, entre el polvo de los túneles, era dirigido a golpes por los Sturmführer S.S. en persona." (p. 318) O narrador conclui que como o trabalho de rebocador era qualificado nos campos de concentração, isso Ihe havia valido para evitar Dora e, portanto, a morte.

Enquanto todos contemplavam "esta palabra mágica, Stukateur, que tal vez (le) había salvado la vida", o personagem-narrador "recordaba la mirada de más allá de la muerte del comunista alemán tratando de explicar por qué era preferible ser un trabajador cualificado en Buchenwald." (p. 319) A imagem da reflexão da memória assume uma ressonância diferenciadora no texto. Agora o Mal do campo se reflete nos olhares "atónitos" dos presentes como memória da salvação da vida, do gesto solidário do companheiro comunista alemão. A digressão do narrador "reflete" sobre esse gesto, apontando as conseqüências negativas de sua negação, se não houvesse sido praticado. $O$ olhar do funcionário alemão reflete o orgulho desse gesto antigo: "Busqué la mirada del cuadragenario barbudo y melancólico. Brillaba con un fulgor nuevo. Una especie de orgullo viril le iluminaba la mirada." (p. 319)

No próximo fragmento, o narrador dialoga com o texto de Primo Levi a respeito dos fatores da sobrevivência nos campos de concentração. Trata-se de uma entrevista com Philip Roth. Nela, Levi aponta o estado de saúde, saber alemão e a sorte como fatores que contribuem para a pouca chance de sobreviver aos campos. O narrador considera-os "elementos objetivos" aos quais acrescenta 
"un factor subjetivo: la curiosidad". (p. 320) Para reforçar o argumento da curiosidade, ele transcreve um trecho da entrevista de Levi. A nova descoberta, no entanto, implica uma mudança de reflexão, uma contraposição a Levi:

"Toda mi vida - mi supervivencia - había estado pensando lo mismo. (...) Pero aquel domingo de marzo de 1992, en la Plaza de Buchenwald, la aparición de la ficha establecida el día de mi llegada, y esa palabra incongruente, Stakateur, me obligaba a una nueva reflexión." (p. 320)

O novo opõe-se ao mesmo criando um deslocamento no olhar reflexivo sobre a sobrevivência. Segundo o narrador, apesar de a sorte tê-lo colocado diante daquele prisioneiro comunista alemão, cuja atitude podia ter sido momentânea, inclusive esquecida, havia se imposto o fator causal: "No importa, porque era comunista, este alemán anónimo me salvó la vida." (p. 321, itálico nosso) Nas palavras do narrador, o prisioneiro agira conforme os valores morais de solidariedade e fraternidade do comunismo. Valores estes que, contraditoriamente, deram origem a práticas históricas "sangrientas, asfixiantes, moralmente destructoras." (p. 321)

Em seguida, o narrador conta a história da organização clandestina do partido comunista alemão em Buchenwald, o K.P.D., e as condições vividas pelos comunistas alemães quando Stalin faz um pacto com Hitler, em 1939. O sentido da fraude e da traição está presente neste relato que procura compreender a dureza e a desilusão do comportamento desses prisioneiros que constituíam um grupo privilegiado em Buchenwald. O narrador procura explicar a traição aos valores humanistas, o mal no comportamento da organização de resistência no campo, em função da traição do pacto germano-soviético:

¿Se puede hacer el esfuerzo necesario para imaginar qué representa
ser un comunista fiel, en Buchenwald, en 1939, en el momento del pacto
entre Stalin e Hitler? ¡Qué discusiones, qué desgarramientos, qué
enfrentamientos debió de producir este acontecimiento en las
organizaciones ilegales de Buchenwald!" (p. 322)

Esta "historia terrible" de traição revela-se ocultando-se e mostrando-se "en las miradas, en los silencios, en las palabras veladas de los comunistas alemanes" que ele conheceu em Buchenwald e explica o Mal, a "parte oscura de sombra, de abominable horror existencial" de seus comportamentos e atitudes. Embora a 
narrativa não dê nenhum exemplo do comportamento dos prisioneiros alemães veteranos, percebemos um ressentimento na digressão especulativa sobre os mesmos. O narrador descreve o olhar do comunista anônimo que o fichou como "más allá de cualquier sufrimiento, de cualquier muerte, de cualquier compasión". Seu gesto é visto como um momento raro em que este olhar se volta ao próximo, em que a idéia de fraternidade que o despertara para a militância comunista brilhasse como uma chama vacilante em sua mente. Neste raro momento, nem "el horror, ni la mentira, ni la muerte" podiam sufocar essa chama. A luz da fraternidade opõe-se assim à sombra do horror no texto: "Una idea de la fraternidad que todavía se oponía al despliegue funesto del Mal absoluto." (p. 323) A sobrevivência é expressa como um momento em que a luz, em luta com a sombra, sobrepuja-a, ainda que vacilante. A diferenciação e a vida surgem da luta da luz contra as trevas, não nos moldes do arquétipo cristão ocidental, mas dentro de uma concepção dialética da história do homem. ${ }^{122}$

De volta ao Hotel Elephant, na mesma noite da visita, o personagemnarrador sonha novamente com Buchenwald: "la nieve había vuelto a caer sobre mis sueños." (p. 323) A ação de sobreposição volta ao texto com o sentido de superação diferenciadora. A neve de seu sonho tem como paisagem o campo transformado:

"No era la nieve de antaño. O mejor dicho, lo era, pero había caído sobre mi última visión de Buchenwald. La nieve había caído, en mi sueño, sobre el campo de Buchenwald tal y como se me había presentado aquella mañana." (p. 324)

O motivo do sonho com a imagem obsessiva da neve origina uma digressão do narrador sobre a história do campo após a libertação. Poucos meses

\footnotetext{
${ }^{122}$ Alfredo Bosi discute esta relação dialética entre o idêntico e o outro em "Acaso, necessidade", mostrando como uma tendência teórica do pensamento dialético marxista, marcada, segundo o autor, por um determinismo e um fechamento em face do termo "dialética", despreza a atenção à contingência e ao novo por serem vistos como "cego acaso", impróprios à objetividade científica, produtores de ilusões idealistas românticas. Em contrapartida, o autor propõe a vigência de um método dialético "de entender a realidade que pressupõe a existência de momentos diferenciais, mas não absolutiza a diferença” (p. 457) Sua conclusão articula a "categoria da possibilidade" enquanto estruturadora da "interação histórica de identidade e alteridade" e vislumbra, inclusive, a incorporação científica de imagens metafóricas como "trevas e reino" a fim de não cair na inconsistência de "todos os dualismos radicais" (p. 459) IN BOSI, Alfredo. "Acaso, necessidade" in Céu, Inferno. 2a edição, SP: Editora 34, 2003, p. 449-459.
} 
depois da saída dos nazistas, Buchenwald convertera-se num campo de concentração do regime soviético. Em 1950, foi desativado. O relato ressalta o bosque renascido no Campinho, lugar onde se sepultaram vítimas do estalinismo: "El bosque recuperado no sólo cubría el antiguo campo de cuarentena: cubría y ocultaba los cadáveres de esos miles de muertos, de esos miles de víctimas del estalinismo." (p. 325) O bosque contraditoriamente esconde e apaga os genocídios do regime totalitário da República Democrática Alemã ao mesmo tempo em que significa a renovação da vida. Para o narrador, a nova Alemanha reunificada possui uma singularidade que manifesta uma contradição fundamental na história de nosso século xx:

"es el único país europeo al que le ha tocado vivir, padecer, y asumir críticamente también, los efectos devastadores de las dos iniciativas totalitarias del siglo xx: el nazismo y el bolchevismo." (p. 326)

E conforme sua visão dialética da História, a radicalidade da contradição, do Mal, pode engendrar a transformação:

"las mismas experiencias políticas que hacen que la historia de Alemania sea una historia trágica, también pueden permitirle situarse en la vanguardia de una expansión democrática y universalista de la idea de Europa." (p. 326)

A conclusão da cena da visita a Buchenwald corresponde a um novo despertar ambíguo. No sonho, o personagem-narrador caminhava pela neve no novo bosque sobre o antigo Campinho, com Thomas e Mathieu, contando-lhes sobre os domingos com Halbwachs, as sessões de recitação de poesia, as latrinas, quando estes ficam para trás, atolados na neve. De repente, ele volta para o seu barracão, sob a neve caindo em redemoinho, como naquele domingo em que ouvira o testemunho do sobrevivente do Sonderkommando de Auschwitz. Trata-se de um retorno aos seus vinte anos. Em seguida, o personagem-narrador acorda e evoca aquela situação.

A passagem para a evocação é tratada como um regresso ao presente através do regresso ao campo de antanho: "Me desperté, en la habitación del Hotel Elephant. Ya no estaba soñando, había regresado a ese sueño que había sido mi vida, que será mi vida." (p. 327) A recordação do testemunho do 
sobrevivente de Auschwitz destaca a solidão do personagem-narrador, no barracão da enfermaria, junto a Ludwig G., o Kapo do barracão. Neste silêncio, "retumbaba el eco del relato del superviviente de Auschwitz." (p. 327) O eco como manifestação do Mal do campo é retomado. Mas a descrição da voz do sobrevivente de Auschwitz agora exemplifica os motivos dessa variação. A voz ficava monótona, regular, precisa e neutra quando "relataba el horror de una visión de conjunto, globalmente: horror colectivo, abstracto" (p. 328); tornava-se precipitada, emocionada, ao tratar de algum detalhe como o olhar desamparado de uma mulher a um parente selecionado na chegada para a câmara de gás. À diferença do segundo capítulo do livro em que o personagem-narrador não se lembra dos detalhes, em que a variação da voz é apontada "sin motivo aparente", neste o eco reverbera a dialética do particular e do geral, do familiar e do estranho, do concreto e do abstrato. Foi necessário que o sobrevivente se distanciasse emocionalmente do tempo do vivido para que ele pudesse dar testemunho do que the era tão próximo. Somente superando o particular, o familiar, o concreto, em sua memória, ele pôde dar testemunho do mesmo.

No silêncio do barracão, o personagem-narrador sussurra uns versos de Brecht, os mesmos rememorados no quarto capítulo do romance com Rosenfeld. Agora, porém, estes versos dialogam com os versos recitados por Ludwig G.. ${ }^{123}$ Tanto os versos do personagem-narrador quanto os de Ludwig respondem à responsabilidade alemã "que Heidegger negaba obstinadamente a considerar" em sua correspondência com Jaspers. Isso é comentado pelo narrador no fragmento anterior.

A cena conclui com a rememoração das chamas alaranjadas da fumaça do crematório sobre a crista do Ettersbeg. Correndo de volta ao barracão, ao som estridente do toque de recolhida, primeiro o personagem-narrador contempla 0 "mistério radiante de una oscura claridad lunar" (p. 329) A neve havia parado de cair. Tomado pela emoção, ele diz: "Me acordaré toda mi vida de esta felicidad

\footnotetext{
${ }^{123}$ Estes são os versos de Brecht recitados por Ludwig G., transcritos pelo narrador na obra: Deutchland, du Blondes, Bleiches Wildwolkiges mit sanfter Stirn!

Was ging vor in deinen lautlosen Himmeln?

Nun bist dud as Aasloch Europas.
} 
insensata, (...) De esta belleza nocturna." (p. 330) Em seguida, alça o olhar e comtempla a fumaça laranja sobre o Ettersberg. $O$ trecho final reúne as imagens emblemáticas do campo numa nova imagem: a neve cessa e o céu abre-se para a ambígua claridade escura da lua; a fumaça do crematório sobrepõe-se ao Ettersberg. $\mathrm{Na}$ evocação, o personagem-narrador transforma-se em narrador. $\mathrm{O}$ uso do futuro do indicativo ("me acordaré") propicia essa leitura. A contemplação e a felicidade insensata de Semprún (personagem-narrador e narrador) nessa rememoração apontam para uma reconciliação momentânea com esse passado.

Por outro lado, a transição narrativa do novo sonho com Buchenwald para a antiga lembrança do testemunho do sobrevivente de Auschwitz representa a transposição de um testemunho a outro, sem possibilidade de conclusão e reconciliação final. O regresso a Buchenwald possibilita-lhe um novo sonho que Ihe abre espaço para enveredar pelas lembranças de outro testemunho. O sonho e a realidade encontram-se através de um movimento contínuo da narrativa. A passagem de uma narração a outra, sem o uso da fragmentação, representa a transposição transformadora de uma forma de testemunho a outra, a abertura para infinitas representações de uma história interminável.

A neve, como no oitavo e nono capítulos do livro, reaparece neste sob a forma do antigo sonho, repetitivo, interminável, agora porém renovado. ${ }^{124} \mathrm{O}$

\footnotetext{
${ }^{124} \mathrm{O}$ estudo de Alicia Molero de la Iglesia define, além do desencanto ideológico, o exílio, a morte e a deportação, a relação entre arte e verdade como um dos temas da obra de Semprún. Molero de la Iglesia distingue dois grandes ciclos na narrativa de Semprún: o da experiência de Buchenwald e a desilusão do comunismo. Ao contrário de Minik ou de Munné, a autora entende que a memória não se constitui em um elemento estruturador da narração de Semprún, mas sim que a temática da cultura literária é a que estrutura a memória e o modo de narrar do escritor. Para Molero de la Iglesia, o proceso associativo de imagens literárias e culturalistas e o emprego iterativo de fatos-sinais de naturaleza simbólica (como o blanco da neve associado à morte em Buchenwald e ao tempo do esquecimento e à não escrita desta morte) consistem em recursos da imaginação criativa que proporcionam estabilidade à memória e operam como argumento e fío condutor de sua narrativa. Segundo a autora, a tarefa de contar renovadamente as experiências de sua vida em função de uma revisão autoexpressiva e da linguagem constitui o princípio organizador de seus textos. A autora concebe a escrita do escritor uma autoficção cujos processos reiterados de construção da identidade fragmentada geram diversos personagens, histórias, obras, atravessadas pelas recorrências de fatos, dados, motivos e paralelismos de uma mesma vida. Segundo Molero, a própria concepção de Semprún da relação entre vida e arte, tema presente em todas suas obras, é responsável desta diversidade de personagens e histórias articuladas em formas de autonarração distintas. Nas palavras de Semprún citadas por Molero de la Iglesia, "un poco de artificio nos aproxima al arte, por tanto a la verdad, del mismo modo que su exceso nos separa de ella". Na visão de Molero, se o auto-relato é retomado por diversas afluências e se mescla a seu culto à cultura, é porque há uma permanente reflexão deste escritor comprometido sobre a interpenetração entre vida e literatura que resulta na reescrita renovada de sua vida. O singular da crítica de Molero de la Iglesia é perceber a reflexão sobre a relação entre arte e verdade como causa de uma produção literária recheada de
} 
percurso da terceira parte do romance desenha primeiro a neve que invade e se inscreve nas páginas do livro que escreve o personagem-narrador; logo, a neve antiga apaga sua escrita em espanhol, que deve então ser reescrita; por último, ela aparece em forma de um sonho novo. Mas ao despertar, a neve torna-se lembrança, recupera o estatuto de antiga realidade e volta a apagar-se, a desaparecer. O fim da tormenta de neve alude à transformação do tormento, mas representa a continuidade infinita de um processo de superação.

\title{
6. Considerações finais: a estrutura dialógica-dialética fragmentária do texto como objetivação formal da precariedade
}

\author{
Afirmamos que a história do protagonista de La escritura o la vida \\ desenvolve-se em um processo dialético negativo cuja necessidade para \\ representar o caráter precário da matéria imprime a precariedade na forma do \\ dados autobiográficos, mas não restringida aos modelos tradicionais da escrita de si mesmo - a ausência de \\ cronologia biográfica e de linearidade nas obras de Semprún o corrobora. Por destacar a decepção de \\ Semprún com a dialética marxista, Molero de la Iglesia não enxerga a influência da dialética na concepção \\ que o autor tem da relação entre arte e história nos seus textos. In IGLESIA, Alicia Molero de la. $L a$ \\ autoficción en España: Jorge Semprún, Carlos Barral, Luis Goytisolo, Enriqueta Antolín y Antonio Muñoz \\ Molina. Neuchâtel, Switzerland: Peter Lang, 2000.
}


romance. A transformação do personagem-narrador em narrador da catástrofe do campo envolve a incorporação da negatividade extrema da cisão radical de sua identidade imposta pela vivência em Buchenwald. A assunção desta negatividade através da elaboração literária compromete contínua e renovadamente a existência de sua própria identidade de sobrevivente testemunha escritor. A história desta transformação precária ocorrida após o campo é uma mediação para se aproximar dos anos vividos em Buchenwald. Ou seja, ela é um meio pelo qual o narrador dialoga com a negatividade do passado de Buchenwald. Assim, poderíamos dizer que toda esta história conforma a relação dialética negativa do narrador com a catástrofe. Dialética porque esta segunda transformação deriva da tentativa de superação do sobrevivente da negatividade do campo, portanto, deriva de sua negação e assunção da negação.

De fato, a história desta segunda transformação dialética tem como princípio organizador o diálogo representado em uma forma espiralada cujo padrão narrativo é fragmentário. Numa seqüência de contraposições, a narrativa encena em cada capítulo uma situação de diálogo do personagem-narrador com personagens do mundo exterior ao campo de concentração, com personagens do mundo concentracionário ou com vozes de diversos textos, que põem em xeque a possibilidade de assumir sua identidade de sobrevivente testemunha escritor do Holocausto. Desta maneira, o narrador dialoga e se contrapõe a seu eu passado e a vozes de fora e de dentro do campo, mostrando como foi necessária uma transformação no diálogo com sua vivência para que ele pudesse identificar-se como sobrevivente e elaborar literariamente seu testemunho. A possibilidade de reconstrução da identidade do narrador, a de transmissão de seu testemunho e a de sua elaboração literária estão em relação recíproca e dependem da capacidade de recepção do mundo. Assim, o diálogo constitui um princípio de composição precário do romance na medida em que traz a história dos impasses deste narrador em face do mundo, disposta em um movimento narrativo dialético e fragmentário. O diálogo assinala a história da transformação da incapacidade de ouvir do mundo e da dificuldade de narrar, descrever, refletir e evocar do narrador. Ao final desse processo, essas dificuldades transformam-se em uma possibilidade 
de elaborar a experiência e conversar com o mundo sempre de modo provisório, fragmentado, inacabado e interminável.

As histórias encaixadas, as digressões do narrador, as evocações líricas e as reflexões do personagem-narrador formam as situações dialógicas principais e secundárias que giram em torno da cena central de cada capítulo e configuram idas e vindas ao redor de um tênue fio narrativo. Mas essas idas e vindas são elaboradas segundo um movimento dialético, isto é, de modo que o narrador dialogue, contrapondo-se ao mal do campo para expor sua negatividade. É através da rememoração fragmentada destas situações dialógicas que o narrador representa o processo de ressubjetivação de sua identidade. Assim, a inclusão de um ou outro fragmento em determinado momento do enredo articula-se com a relação dialética de identificação e estranhamento, de proximidade e distanciamento, entre o narrador e as facetas humanas e textuais de seu universo. O romance mobiliza o recurso da lei da repetição, através do emprego da antítese, da gradação e do paralelismo, conjugados ao nível das ações, das imagens, das descrições espaciais, da construção das personagens e do tratamento do tempo, para objetivar este movimento dialético entre iteração e variação, ligado ao sentido da experiência do campo. A morte infinita do campo, a eternidade do tempo de encarceramento em Buchenwald, o modo obsessivo como as lembranças dessa experiência manifestam-se no sobrevivente constituem a tarefa interminável de narrá-la sempre buscando o novo sentido que explicaria a dialética entre a necessidade e a liberdade desta segunda sobrevivência: a necessidade de negála e a impossibilidade de assumi-la em relação com a necessidade de assumi-la e a impossibilidade de negá-la. A espiral representa a repetição renovada do sentido da experiência do campo de concentração, que determina a necessidade de superação permanente de sua sobrevivência.

Assim, o texto mobiliza diversas práticas discursivas articuladas com as situações dialógicas para problematizar as dificuldades que o sobrevivente teve para testemunhar a experiência do campo. A inclusão parcial das formas de discurso na situação dialógica central de cada capítulo acena para uma tensão significativa entre formas de discurso, que remete, em última instância, à condição 
precária da testemunha para narrar, descrever, evocar e refletir sobre sua experiência no diálogo com o mundo. A fragmentação discursiva, pois, informanos sobre a precariedade do processo dialógico do narrador com a negatividade do campo.

Nesse sentido, por exemplo, a descrição das mudanças dos olhares e das vozes do personagem-narrador e das personagens, como signos perceptivos e expressivos da realidade do campo, indicia a transformação deste sobrevivente e do mundo. As três fases dialéticas estão indiciadas nas descrições destes órgãos sensitivos. Através de sondagens descritivas, a narrativa representa o que há na dimensão da aparência, dos vestígios deixados pela experiência do horror: a voz e o olhar da morte, o olhar dos de fora, o olhar de silêncio, o silêncio da voz, a voz do sonho, a voz da realidade, a voz da memória, o olhar da dignidade, o olhar da inocência, etc. Tais descrições informam-nos as possibilidades do narrador em sua relação com o mundo para a ressubjetivação de sua identidade.

A reflexão, por sua vez, entra como forma de superação paradoxal e dialética, pois também se constitui em um modo aproximativo do insuperável. As reflexões do narrador contrapostas às do personagem-narrador e de outras vozes mostram uma tensão que representa o tempo da imaturidade das reflexões do sobrevivente. É como se o texto informasse que somente recorrendo à digressão do narrador fora possível comunicar a contradição do que estava dado no passado. O tempo de protelação deste testemunho em forma de romance significa um importante registro da precariedade do sobrevivente objetivada na oscilação do foco narrativo, repondo constantemente uma relação tensa entre a ordem do enunciado e a da enunciação. Assim, a digressão registra os enganos de visão e a falta de perspectiva reflexiva do sobrevivente no decorrer de sua transformação em escritor e indica que a "forma ideal" perseguida pelo narrador compreende a superação da mera narração e descrição. A digressão assinala um domínio precário, renovado continuamente, do narrador sobre a matéria e sua forma, penosa e fragmentariamente conquistado após 47 anos.

Embora o discurso lírico e o reflexivo signifiquem um modo de superação, é em parte na oposição da evocação lírica à digressão que reside o caráter negativo 
da matéria. A necessidade e/ou possibilidade de o narrador evocar versos numa dada situação narrativa informam sobre sua estratégia de sobrevivência e de superação. Do mesmo modo, a presença ou a ausência de recitação de versos nos diálogos assinala o grau de identificação e de estranhamento do sobrevivente com o outro e as possibilidades de encontrar uma comunidade de ouvintes para seu testemunho. Além disso, o diálogo do sobrevivente com a literatura e a poesia em oposição ao seu diálogo com a retórica lógica do discurso reflexivo de caráter filosófico e científico desvela sua dificuldade em ancorar-se nas operações do logos em momentos traumáticos de sua história. Mas se o papel da poesia, da literatura e da filosofia na vida deste sobrevivente é o de mediar a superação da barbárie implicada no sofrimento do Mal do campo, mostrando a insuficiência da narração e da descrição para representar a matéria, ambas também revelam como a elaboração dessa vivência se dá no modo de um conflito entre vozes e de uma fragmentação de discursos.

É servindo-se da tensão entre vozes dispostas em diversas formas discursivas que o narrador reflete sobre a vivência do campo. As "variações e improvisações sobre os mesmos temas" constituem um modo de exprimir como o campo só pode ser elaborado através de idas e vindas de um processo em que o narrador negava a negatividade do campo para poder assumi-la. Ou seja, é assim que se revela o caráter negativo e fragmentário da matéria, concebida pelo narrador em forma de temas dialéticos. Nas situações dialógicas centrais e secundárias do enredo, o narrador expõe a concepção dialética que ele foi desenvolvendo do campo. As contradições entre morte e vida, dentro e fora, antes e depois do campo de concentração, realidade e sonho, dignidade e abjeção, fraternidade e Mal absoluto, esquecimento e lembrança, conhecimento e ignorância, culpa e inocência, liberdade e necessidade, humano e inumano, verdade e ficção, fala/escrita e silêncio, casualidade/acaso e causalidade/moral, aparência e essência, idêntico e não-idêntico assumem sentidos negativos diferentes conforme a transformação vai acontecendo na vida do sobrevivente. A relação antitética entre esses binômios submete-se ao sentido de cada capítulo, mostrando como a concepção do narrador sobre a matéria acompanha o 
desenvolvimento dialético de seu diálogo com a mesma. A narrativa é fiel ao desenvolvimento do protagonista em articulação com 0 tempo dos acontecimentos.

Ao adotar as incertezas e as limitações de um ponto de vista colado à situação narrativa, a perspectiva de 47 anos depois torna-se fiel a uma história de tentativas e fugas, idas e vindas em torno do dilema aporético de viver ou morrer, lembrar ou esquecer, testemunhar ou silenciar, escrever ou ... Por um lado, o encurtamento do foco narrativo ajusta-se não somente à representação da dificuldade de distanciamento e esclarecimento do sobrevivente em face da realidade a ser elaborada, ao longo dos momentos em que ele quis testemunhar e, não podendo, silenciou-se, mas também à representação da ameaça permanente de catástrofe. Por outro lado, a narração em primeira pessoa do singular deriva da assunção de um lócus de enunciação singular e insubstituível, o do sobrevivente testemunha escritor, transformando sua negatividade imanente em elemento de negatividade transcendente ou de transcendência negativa. Para mostrar que o protagonista não pôde e não pode nunca habitar confortavelmente o lugar de sobrevivente do Holocausto, a narrativa representa um desdobramento e uma transformação do personagem-narrador em narrador-personagem, que não suspendem, contudo, sua força devastadora. O contraponto entre a perspectiva do narrador e aquela "em situação" do personagem-narrador configura as dificuldades de tornar o lugar da testemunha minimamente habitável. A oscilação do foco narrativo ora adia a narração da experiência traumática, ora indica a urgência do ato de testemunhar que, articulada ao presente verbal, representa o agora como possibilidade constante de uma iminente catástrofe. É na relação do sobrevivente, em cada momento da narrativa, com as lembranças obsessivas de Buchenwald que se trava a luta para tornar-se uma testemunha escritor. A narrativa captura a inaptidão do sobrevivente a viver o presente como uma luta contraditória permanente. O mundo do campo de concentração aparece então através das incursões do narrador e do personagem-narrador nas lembranças do campo ou como regresso repetitivo em busca do sentido de sua identidade. $O$ universo concentracionário surge como um conflito permanente do sobrevivente 
na sua busca por exercer um domínio contra a ação mortífera dessas lembranças, assumindo-as, no desfecho da história, em uma atitude de passividade ativa, forma dialética da conquista provisória desse domínio. O jogo da oscilação do foco narrativo reitera a instabilidade de um lugar de enunciação que a qualquer momento pode ruir e fazer sucumbir este enunciador a uma crise de dessubjetivação.

A idéia moderna enunciada pela forma romanesca contemporânea de que não é mais possível narrar uma história nos moldes tradicionais da narrativa, de que seu sentido, revelado provisoriamente, é adiado em razão da precariedade da condição histórica do homem contemporâneo e de seus sistemas explicativos, é radicalizada neste romance testemunhal.

A fragmentação de La escritura o la vida indica que não é possível narrar de modo linear, porque a sucessão dos fatos numa ordem cronológica linear, a perspectiva narrativa unívoca e a pureza discursiva não podem capturar o sentido da experiência do campo. Conforme a estrutura deste romance testemunhal, a essência da experiência em Buchenwald é negativamente dialética, porque dela surgiu um ser fragmentado, dilacerado, dessubjetivado e alienado cujo processo de ressubjetivação teve como etapas a negação deste ser e a posterior aceitação dessa negatividade extrema e inconciliável para que ela pudesse ser superada, ainda que e necessariamente de maneira provisória e precária. A fragmentação da forma manifesta assim o processo permanente e dialético da reconstrução de sentido de sua identidade. Trata-se, portanto, de um processo de reconstrução de sua identidade que se dá somente mediante a incorporação de sua negatividade extrema, a da fragmentação do ser, objetivada na fragmentação da forma.

A negatividade de La escritura o la vida deriva da infinitude da matéria. A tarefa do testemunho representada neste romance e em outros do autor é interminável, portanto insuperável e sua fragmentação é um aspecto de seu caráter infinito, é a finitude do infinito, a contradição pela qual ele chega a ser o que é. A superação deste sobrevivente da catástrofe neste romance é conservação da negatividade, do luto, da dor, embora apaziguada, sempre dor. Mas não é cessação, fazer cessar, pôr fim à realidade iminente da catástrofe. 
Portanto, ela não pode ser chamada de superação de fato ou reconciliação com o mundo. A superação aqui envolve a luta constante da consciência por um modo de não sucumbir à fragmentação inegável e persistente do ser resultante da catástrofe.

\section{Referências Bibliográficas}

\subsection{Obras de Jorge Semprún}

SEMPRÚN, Jorge. A montanha branca. Trad.: Edison Darci Heldt. Rio de Janeiro: Nova Fronteira, 1987.

. Aquel Domingo. Trad.: Javier Albiñana. Barcelona: Tusquets Editores, 2004.

Autobiografía de Federico Sánchez. Trad.: Olga Savary. Barcelona: Tusquets Editores, 2004.

. El Largo Viaje. Trad.: Jacqueline y Rafael Conte. Barcelona: Tusquets Editores, 2004.

- Homenaje a Jorge Semprún: palabras pronunciadas en ocasión de la entrega de la Medalla de Honor de la UIMP a don Jorge Semprún el 20 de agosto de 2004 en Santander. Santander: Universidad Internacional Menéndez Pelayo, 2006, p. 1-56. 
Editores, 1995.

La escritura o la vida. Trad.: Thomas Kauf. Barcelona: Tusquets

. Netchaiev ha vuelto. Trad.: Thomas Kauf. Barcelona: Tusquets Editores, 1988.

- Pensar en Europa. Barcelona: Tusquets, 2006.

. (prólogo) in KLÜGER, Ruth. Seguir Viviendo. Barcelona: Círculo de Lectores, Galaxia Gutenberg, 1997, p. 5-8.

. Viviré con su nombre, morirá con el mío. Trad.: Carlos Pujol. Barcelona: Tusquets Editores, 2002.

\subsection{Fortuna Crítica de Jorge Semprún}

AGUADO, Txetxu. "Memory, Politics, and Post-national Citizenship in Jorge Semprún's L'Ecriture ou la vie" in Hispanic Research Journal: Iberian and Latin American Studies, v. 3, n. 6, Oct 2005, p. 237-251.

ANDERSON, Connie. "Artifice and Autobiographical Pact in Semprun's L'Ecriture ou la vie" in Neophilologus, v. 4, n. 90, 2006, Oct, p. 555-573.

BOU, Enric. "Construcción autobiográfica y exilio: Entre la memoria individual y la colectiva" in Revista Canadiense de Estudios Hispánicos, v.1, n. 3, Fall 2005, p. 17-32.

BOWIE, José Antonio Pérez. "Dos reflexiones cinematográficas sobre el exilio: El ángel exterminador de Buñuel y La guerra ha terminado de Resnais-Semprún" in Nueva Literatura Hispánica, n. 3, 1999, p. 155-172.

CORTANZE, Gérard de. "Aux côtés des Espagnols" in Magazine Littéraire, n. 377, June 1999, p. 33-35.

. “Jorge Semprún: L'Espagne sans retour" in Magazine Littéraire, n. 347, Oct 1996, p. 35-41. 
DE MARCO, Valeria. "La escritura o la vida: la imposibilidad de ver", texto mimeografado, 2001, p. 1-32.

FERRÁN, Ofelia. "'Cuanto más escribo, más me queda por decir': Memory, Trauma, and Writing in the Work of Jorge Semprún" in MLN, v. 2, n. 116, Mar 2001, p. 266-294.

. "'El largo viaje' del exilio: Jorge Semprún" in SOLER, Manuel Aznar (ed.) El exilio literario español de 1939. V. 2., Serpa Pinto 1. Barcelona, Spain: Grup d'Estudis de I'Exili Literari, Departament de Filologia Espanyola, Universitat Autònoma de Barcelona (GEXEL), 1998, p. 107-115.

GALLY, Ricardo Cayuela. "Entrevista con Jorge Semprún: La memoria como escritura" in Letras Libres, v.5, n. 60, Dec 2003, p. 36-42.

GARSCHA, Karsten. "Del cambio de nombre y de muerte: Sobre Le mort qu'il faut de Jorge Semprún" in PAATZ, Annette (ed. and preface) POHL, Burkhard (ed. and preface) BERGENTHAL, Kathrin (epilogue). Texto social: Estudios pragmáticos sobre literatura y cine: Homenaje a Manfred Engelbert. Berlin, Germany: Tranvía-Frey, 2003, p. 279-296.

IGLESIA, Alicia Molero de la. La autoficción en España: Jorge Semprún, Carlos Barral, Luis Goytisolo, Enriqueta Antolín y Antonio Muñoz Molina. Neuchâtel, Switzerland: Peter Lang, 2000.

ILLESCAS, Raúl. “Jorge Semprún: La escritura o la vida. Holocausto y literatura” in LEMER, Isaías (ed.) NIVAL, Robert (ed.) ALOSO, Alejandro (ed.) Actas del XIV Congreso de la Asociación Internacional de Hispanistas, III: Literatura española, siglos XVIII - XX. Newark, De: Cuesta, 2004, p. 315-322.

KAPLAN, Brett Ashley. "'The Bitter Residue of Death': Jorge Semprun and the Aesthetics of Holocaust Memory" in Comparative Literature, v. 4, n. 55, Fall 2003, p. $320-337$.

LOUREIRO, Angel G.. "Semprún: Memorial de ausencias" in Cuadernos Hispanoamericanos, n. 617, Nov 2001, p. 21-29. 
MINIK, Domingo Pérez. "El desvanecimiento, de Jorge Semprún" in Insula: Revista de Letras y Ciencias Humanas, n. 394, 1979, p. 7.

MUNNÉ, Antoni. "La memoria y la experiencia" in Quimera: Revista de Literatura, n. 14, Diciembre 1981, p. 76-79.

NIETO, Felipe. "La 'resurrección' de Jorge Semprún: El regreso de Buchenwald" in Revista de Occidente, n. 266-67, Julio-Agosto 2003, p. 205-215.

ORTEGA, José. "Intriga, estructura y compromiso en La segunda muerte de Ramon Mercader, de Jorge Semprún" in Cuadernos Hispanoamericanos: Revista Mensual de Cultura Hispanica, n. 310, 1976, p. 160-175.

RIERA, Miguel. "Al filo de la escritura: Entrevista con Jorge Semprún” in Quimera: Revista de Literatura, n. 88, Abril 1989, p. 20-27.

RODRÍGUEZ, Jesús. "Historia de un desengaño: Los hijos de Federico Sánchez" in Cuadernos de Aldeeu, v.2, n. 9, Nov 1993, p. 255-266.

ROMERO, María del Carmen Molina. "Identité et altérité dans la langue de l'autre" in Théleme - Revista Complutense de Estudios Franceses, n. 18, 2003, p. 69-79.

SÁNCHEZ, Ana María Amar. "La ficción del testimonio" in Revista Iberoamericana, 56:151, Abril.-Junio 1990, p. 447-461.

SINNIGEN, J.. Narrativa e ideología. Madrid: Nuestra Cultura, 1982.

SOTO-FERNÁNDEZ, Liliana. La autobiografia ficticia en tres autores del siglo XX: Unamuno, Martín Gaite y Semprún Madrid: Editorial Pliegos, 1996.

TIDD, Ursula. "The Infinity of Testimony and Dying in Jorge Semprún's Holocaust Autothanatographies" in Forum for Modern Language Studies, v. 4, n. 41, Oct 2005, p. 407-417.

\subsection{Bibliografia Geral}


ABDALA JUNIOR, Benjamin. Introdução à análise da narrativa. São Paulo: Scipione, 1995.

ACHUGAR, Hugo. "Historias paralelas/historias ejemplares; La historia y la voz del otro" in BEVERLEY, John; ACHUGAR, Hugo (ed.) La voz del otro; Testimonio, subalternidad y verdad narrativa. Número especial da Revista de crítica literária latinoamericana, año XVIII, n. 36, Lima, $2^{\circ}$ semestre, 1992, p. 49-71.

ADORNO, Theodor W.. "Crítica cultural e sociedade" in Prismas. Trad.: Augustin Wernet e Jorge Mattos Brito de Almeida. São Paulo: Ática, 1998, pp. 7-26.

"Educação após Auschwitz" in COHN, Gabriel (org.) Theodor W. Adorno. São Paulo: Editora Ática, 1986.

- Dialéctica Negativa- La jerga de la autenticidad. Trad.: Alfredo Brotons Muñoz. Madrid: Ediciones Akal, 2005.

- Minima moralia. Lisboa: edições 70, 2001.

"O ensaio como forma" in Notas de Literatura I. Trad.: Jorge de Alemeida. São Paulo: Editora 34, 2003.

- "Posição do narrador no romance contemporâneo" in Notas de Literatura I. Trad.: Jorge de Almeida. São Paulo: Editora 34, 2003.

AGAMBEN, Giorgio. Lo que queda de Auschwitz. El archivo y el testigo. Homo Sacer III. Trad.: Antonio Gimeno Cuspinera. Valencia: Pre-Textos, 2000.

Medios sin fin. Notas sobre la política. Trad.: Antonio Gimeno Cuspinera. Valencia: Pre-Textos, 2001.

—. O poder soberano e a vida nua I. Trad.: Henrique Burigo. Belo Horizonte: UFMG, 2004.

ALVES JR., Douglas Garcia. Depois de Auschwitz - a questão do anti-semitismo em Theodor W. Adorno. São Paulo: Annablume: Belo Horizonte: Fumec, 2003.

AMAT-PINIELLA, Joaquim. Reich. Trad.: Antonio Padilla. Barcelona: El Aleph, 2002. 
AMÉRY, Jean. Más allá de la culpa y de la expiación. Tentativas de superación de una víctima de la violencia. Trad.: Enrique Ocaña. Valencia: Pre-Textos, 2001. AMORÓS, Andrés. Introducción a la novela contemporánea. Madrid: Ediciones Cátedra, 1989.

ANTELME, Robert. La especie humana. Trad.: Trinidad Richelet. Madrid: Arena Libros, 2001.

ANTELO, Raúl. "Delectación morosa: imagen, identidad y testimonio." Manuscrito a ser publicado in Revista de crítica cultural. Santiago de Chile, junio, 1999; in Punto de vista. Buenos Aires, julio, 1999.

- Potências da imagem. Chapecó: Argos, 2004.

APARICIO, Frances R.. Versiones, Interpretaciones y Creaciones: Instancias de la traducción en Hispanoamérica en el siglo veinte. Gaithersburgh, MD: Ediciones Hispamérica, 1991.

APPELFELD, Aharon. "Depois do Holocausto" in Cadernos de Língua e Literatura Hebraica, n. 2, 1999, p. 81-91.

ARAGON, Louis. Nouveau Crève-Coeur. 23ª édition, Paris: Gallimard, 1949. ARENDT, Hannah. Eichmann em Jerusalém. Um relato sobre a banalidade do mal. Trad.: José Rubens Siqueira. São Paulo: Companhia das Letras, 1999.

ARISTÓTELES. Poética. Trad.: Eudoro de Souza. Porto Alegre: Globo, 1966.

ARRIGUCCI JR, Davi. "Gabeira em dois tempos" in Enigma e comentário: ensaios sobre literatura e experiência. São Paulo: Companhia das Letras, 1987, p. 119-139.

- O escorpião encalacrado - A poética da destruição em Julio Cortázar. São Paulo: Companhia das Letras, 2003.

ARROJO, Rosemary. Tradução, Desconstrução e Psicanálise. Rio de Janeiro: Imago, 1993.

AUB, Max. Campo francés. Paris: Ruedo Ibérico, 1965. 
"Conversación post mortem" in PLAZA, Joaquina Rodríguez y HERRERA, Alejandra (org). Relatos y prosas breves de Max Aub. México, Universidad Autónoma Metropolitana, 1993, p. 7-67.

—. Diario de Djelfa. Valencia: Poesia Edicions de la Guerra \& Café Malvarrosa, 1998.

. Enero sin nombre. Los relatos completos del Laberinto Mágico. Barcelona: Alba Editorial, 1994.

AUERBACH, Erich. Mimesis - a representação da realidade na literatura ocidental. São Paulo: Perspectiva, 2002.

BAKHTIN, Mikhail. Estética da Criação Verbal. São Paulo: Martins Fontes, 2003.

BARTHES, Roland... (et al.) Análise estrutural da narrativa - pesquisas semiológicas. Trad.: Maria Zélia Barbosa Pinto. Petrópolis, RJ: Editora Vozes, 1971.

BATAILLE, Georges. La littérature el le mal. Paris: Gallimard, 1957.

BAUMAN, Zygmunt. Modernidade e Holocausto. Trad.: Marcus Penchel. Rio de Janeiro: Jorge Zahar Ed., 1998.

BEHAR, Lisa Block De. Uma retórica del silencio - funciones del lector y procedimientos de la lectura literaria. México, DF.: Siglo Veintiuno, 1984.

BENJAMIN, Walter. Magia e técnica, arte e política. Trad.: Sergio Paulo Rouanet. São Paulo: Brasiliense, 1985.

BETTELHEIM, Bruno. O coração informado - autonomia na era da massificação. Trad.: Celine Cardim Cavalcanti. Rio de Janeiro: Paz e Terra, 1985. - Sobrevivência. Porto Alegre: Artes Médicas, 1989.

BEVERLEY, John. "El testimonio en la encrucijada" in Revista Iberoamericana, v. LIX, n. 164-5, julio-diciembre 1993, p.485-507 
- "Introducción" in BEVERLEY, John; ACHUGAR, Hugo (ed.) La voz del otro; Testimonio, subalternidad y verdad narrativa. Número especial da Revista de crítica literária latinoamericana. Año XVIII, n. 36, Lima, $2^{\circ}$ semestre, 1992, p.7-18.

BLANCHOT, Maurice. La escritura del desastre. Trad.: Pierre de la Place. Caracas: Monte Avila, 1990.

BOOTH, Wayne C.. A retórica da ficção. Lisboa: Arcádia, 1980.

BORGES, Jorge Luis. "El tiempo” in Obra Completa. Barcelona: Emecé, 1996.

BORNHEIM, Gerard A.. Dialética - teoria e práxis. Porto Alegre: Globo, 1977.

BOSI, Alfredo. "A escrita do testemunho em Memórias do Cárcere" in Estudos avançados, v. 9, n. 23, janeiro-abril 1995, p. 309-322.

- Céu, Inferno: ensaios de crítica literária e ideológica. São Paulo: Editora 34, 2003.

. "Fenomenologia do olhar" in NOVAES, Adauto (org.) O Olhar. São Paulo: Companhia das Letras, 1988, p. 70-71.

- O ser e o tempo da poesia. São Paulo: Companhia das Letras, 2000.

BOSI, Ecléa. "O campo de Terezin" in Estudos avançados, v. 13, n. 37, setembro-dezembro 1999, p. 7-32.

- Memória e Sociedade: lembranças de velhos. São Paulo: T. A. Queiroz, Biblioteca de Letras e Ciências Humanas, v. 1, 1979.

BOURNEUF, Roland \& OUELLET, Real. O universo do romance. Trad.: José Carlos Seabra Pereira. Coimbra: Livraria Almeida, 1976.

BRECHT, Bertolt. Poemas: 1913-1956. Trad.: Paulo Cesar Souza. 4a edição, São Paulo: Brasiliense, 1990, p. 124-125.

BUENO, Francisco da Silveira. Grande dicionário etimológico-prosódico da língua portuguesa. São Paulo: Saraiva, 1968.

BUTOR, Michel. Repertório. São Paulo: Perspectiva, 1974. 
CAMPOS, Haroldo de. Metalinguagem e outras metas: ensaios de teoria e crítica literária. São Paulo: Perspectiva, 2004.

CANDIDO, Antonio... (et al.) A Personagem de Ficção. São Paulo: Perspectiva, 2005.

Editora 34, 1992.

Ficção e confissão - ensaios sobre Graciliano Ramos. São Paulo: . Tese e antítese-ensaios. São Paulo: T. A. Queiroz, Editor, 2000.

CANEVACCI, Massimo. (introdução e organização) Dialética do indivíduo - o indivíduo na natureza, história e cultura. Trad.: Carlos Nelson Coutinho. $3^{\mathrm{a}}$ edição, São Paulo: brasiliense, 1981.

CARR, Robert. "Re-presentando el testimonio: notas sobre el cruce divisório primer mundo/tercer mundo" in BEVERLEY, John; ACHUGAR, Hugo (ed.) La voz del otro; Testimonio, subalternidad y verdad narrativa. Número especial da Revista de crítica literária latinoamericana. Año XVIII, n. 36, Lima, $2^{\circ}$ semestre, 1992, p. 73-93.

CARUTH, Cathy. "Modalidades do despertar traumático (Freud, Lacan e ética da memória)" in NESTROVSKI, Arthur e SELIGMANN-SILVA, Márcio (orgs.) Catástrofe e representação. São Paulo: Escut, 2000, p. 111-136.

CARVALHO, Alfredo Leme Coelho de. Foco narrativo e fluxo de consciência Questões de teoria literária. São Paulo: Ed. Pioneira, 1981.

CHAUÍ, Marilena. "Janela da alma, espelho do mundo" in NOVAES, Adauto (org.) O Olhar. São Paulo: Companhia das Letras, 1988, p. 47-59.

COHN, Gabriel. "Indiferença, nova forma de barbárie" in Novaes, Adauto (org.) Civilização e Barbárie. São Paulo: Companhia das Letras, 2004.

CORTÁZAR, Julio. "A situação do romance" in Valise de cronópio. São Paulo: Perspectiva, 1993. 
"Negação do esquecimento" in SOSNOWSKI, Saúl (org.) Obra crítica 3. Trad.: Paulina Wacht e Ari Roitman. Rio de Janeiro: Civilização Brasileira, 2001, p. 291-294.

CUNHA, Antonio Geraldo da. Dicionário etimológico nova fronteira da língua portuguesa. Rio de Janeiro: Nova Fronteira, 1986.

DANZIGER, Marlies K. \& STACY JOHNSON, W. Introdução ao estudo crítico da literatura. Trad.: Álvaro Cabral. São Paulo: Cultrix, 1974.

DAPENA, José Álvaro Porto. Tiempos y formas no personales del verbo. Madrid: Arco/Libros, S. A., 1989.

DRAAISMA, Douwe Metáforas da memória - uma história das idéias sobre a mente. Bauru, São Paulo: Edusc, 2005.

DE MARCO, Valeria. "A literatura de testemunho e a violência de Estado" in Lua nova. São Paulo, n. 62, 2004, p. 45-68.

- "Campo francés: Max Aub y la literatura de testimonio" in Quaderni di Dipartimento di Lingüística. Serie Letteratura 9 Rende, v. 21, 2002, p. 55-68.

. "Histora de Jacobo': la imposibilidad de narrar" in ALONSO, Cecilio (ed) Actas del Congreso Internacional "Max Aub y el laberinto español" celebrado en Valencia y Sogorbe del 13 al 17 de diciembre de 1993. Valencia: Ayuntamiento, v. II, p. 559-565.

. "Literatura de testemunho: aproximação a Ferreira Gular" in SILVEIRA MARTINS, Dileta. (org.) Anais do 18 Seminário Brasileiro de Crítica Literária, 17. Seminário de Crítica do Rio Grande do Sul, Jornada Internacional de Narratologia. Porto Alegre: Edipucrs, 2001, p. 47-70.

. "Questões sobre a literatura de testemunho" in Língua e literatura, São Paulo, n 25, 1999, p. 153-167.

DERRIDA, Jacques. Demeure. Maurice Blanchot. Paris: Editions Galilée, 1998.

DIMAS, Antônio. Espaço e romance. São Paulo: Ática, 1994.

DOMÍNGUEZ, Antonio Garrido. El texto narrativo. Madrid: Síntesis S.A., 1993. 
D'ONOFRIO, Salvatore. Poema e narrativa: estruturas. São Paulo: Duas Cidades, 1978.

DOSTOIÉVSKI, Fiódor. Memórias do subsolo. Trad.: Boris Schnaiderman. São Paulo: Editora 34, 2000.

ECO, Umberto. Obra Aberta. São Paulo: Perspectiva, 2003.

EPPLE, Juan Armando. "Acercamiento a la literatura testimonial de Chile" in Revista Iberoamericana, v. LX, n. 168-169, julio-diciembre 1994, p. 1143-1175.

FELMAN, Shoshana. "Educação e crise, ou as vicissitudes do ensino" in Pulsional. Revista de Psicanálise, ano XI e XII, n. 116-117, dezembro 1998/janeiro 1999, p. 9-48.

FELMAN, Shoshana. e LAUB, Dorie. Testimony: literature, psychoanalysis, history. Londres: Routledge, 1991.

FERREIRA, Aurélio Buarque de Holanda (Ed.). Novo dicionário da língua portuguesa. Rio de Janeiro: Nova Fronteira, 1986.

FLORES, Lauro. "Ideologia y cultura en la autobiografia chicana" in BEVERLEY, John; ACHUGAR, Hugo (ed.) La voz del otro; Testimonio, subalternidad y verdad narrativa. Número especial da Revista de crítica literária latinoamericana, año XVIII, n. 36, Lima, $2^{\circ}$ semestre, 1992, p. 95-107.

FITZGERALD, F. Scott. A derrocada e outros contos e textos autobiográficos. Rio de Janeiro: Civilização Brasileira, 1969.

FORSTER, E. M.. Aspectos do romance. Porto Alegre: Globo, 1969.

FOUCAULT, Michel. O que é um autor? Trad.: Antonio Fernando Cascais e Eduardo Cordeiro. Lisboa: Passagens, 1997.

FRANCO, Jean. "Si me permiten hablar: la lucha por el poder interpretativo" in BEVERLEY, John; ACHUGAR, Hugo (ed.) La voz del otro; Testimonio, subalternidad y verdad narrativa. Número especial da Revista de crítica literária latinoamericana, año XVIII, n. 36, Lima, $2^{\circ}$ semestre, 1992, p. 109-116. 
FREUD, S.. "Luto e melancolia" in Novos estudos Cebrap, São Paulo, n. 32, mar, 1992.

- Psicanálise da guerra. São PAULO: Editorial San Remo, s/d.

FRÍAS, Carlos V.. "El tiempo" in Jorge Luis Borges - Obras Completas, Buenos Aires: Emecé Editores, 1974.

GAGNEBIN, Jeanne Marie. "A (im)possibilidade da poesia" in Cult, São Paulo, n. 23, jun., 1999, p. 48-51.

História e narração em Walter Benjamin. São Paulo: Editora Perspectiva, 1999.

. Lembrar escrever esquecer. São Paulo: Editora 34, 2006.

"Memória, História, testemunho" in BRESCIANI, Stella e NAXARA, Márcia. (orgs.) Memória e (res)sentimento: indagações sobra uma questão sensível. Campinas, SP: Editora da Unicamp, 2001, p. 85-94.

"Palavras para Hurbinek" in NESTROVSKI, Arthur e SELIGMANNSILVA, Márcio (orgs.) Catástrofe e representação. São Paulo: Escuta, 2000, p. 99-110.

GULLAR, Ferreira. Rabo de foguete. Os anos de exílio. Rio de Janeiro: Revan, 1998.

GULLÓN, Ricardo. Espacio y novela. Barcelona: Antoni Bosch editor S. A., 1980. HACKETT, David A.. (org.) O relatório Buchenwald - o dia-a-dia em um campo de extermínio nos depoimentos dos sobreviventes. Trad.: Maria Luiza X. De A. Borges. Rio de Janeiro - São Paulo: Record, 1998.

HARTMAN, Geoffrey. "Holocausto, testemunho, arte e trauma" in NESTROVSKI, Arthur e SELIGMANN-SILVA, Márcio (orgs.) Catástrofe e representação. São Paulo: Escuta, 2000, p. 207-235.

HOBSBAWM, Eric J.. "A Era da Catástrofe" in A Era dos Extremos - O breve XX : 1914 - 1991. Trad.: Marcos Santarrita. São Paulo: Companhia das Letras, 1995. 
- A História Social do Jazz. Trad.: Ângela Noronha. Rio de Janeiro: Paz e Terra, 1990.

HOWE, Irving. "A escrita e o holocausto" in Cadernos de língua e literatura hebraica, Fac. Filosofia Letras e Ciências Humanas/USP - n. 2, 1999, p. 11-37.

IZNAGA, Diana. Presencia del testimonio. La Havana: Editorial Letras Cubanas, p. 338.

JAKOBSON, Roman. "Dois aspectos da linguagem e dois tipos de afasia" in Lingüística e comunicação. São Paulo: Cultrix, s/d.

JAMESON, Fredric. "De la sustitución de importaciones literarias y culturales en el tercer mundo: el caso del testimonio" in BEVERLEY, John; ACHUGAR, Hugo (ed.) La voz del otro; Testimonio, subalternidad y verdad narrativa. Número especial da Revista de crítica literária latinoamericana, año XVIII, n. 36, Lima, $2^{\circ}$ semestre, 1992, p.117-133.

JARA, René \& MORENO, Fernando. Anatomía de la novela. Chile: Ediciones Universitarias de Valparaiso, 1972.

KAYSER, Wolfgang. Fundamentos da interpretação e da análise literária. São Paulo: Saraiva, 1948.

KEHL, Maria Rita. "O sexo, a morte, a mãe e o mal" in NESTROVSKI, Arthur e SELIGMANN-SILVA, Márcio (orgs.) Catástrofe e representação. São Paulo: Escuta, 2000, p. 137-148.

KERTÉSZ, Imre. A língua exilada. Trad.: Paulo Schiller. São Paulo: Companhia das Letras, 2004.

- Sem destino. São Paulo: Editora Planeta do Brasil, 2003.

Um instante de silencio en el paredón. El holocausto como cultura. Trad.: Adan Kovacsics. Barcelona: Herder, 1999.

Yo, otro. Crónica del cambio. Trad.: Adan Kovacsics. Barcelona: Acantilado, 2002. 
KLEMPERER, Victor. LTI La langue du Ille Reich. Trad.: Élisabeth Guillot. Paris: Albin Michel, 1996.

- Os diários de Victor Klemperer. Testemunho clandestino de um judeu na Alemanha nazista. Trad.: Irene Aron. São Paulo: Companhia das Letras, 1999.

KOSELLECK, Reishart. "Terror y sueño. Notas metodológicas para las experiencias del tiempo en el Tercer Reich" in Futuro pasado. Para una semántica de los tiempos históricos. Barcelona: Paidós, 1993, p. 267-286.

KRISTEVA, Julia. O texto do romance. Trad.: Manuel Ruas. Lisboa: Horizonte Universitário, 1984.

LAGES, Susana Kampff. Walter Benjamin: Tradução e Melancolia. São Paulo: Edusp, 2002.

LEFEBVRE, Henri Lógica formal - lógica dialética. Rio de Janeiro: Civilização Brasileira, 1991.

LEÓN, Antonio Vera. "Hacer hablar: la transcripción testimonial" " in BEVERLEY, John; ACHUGAR, Hugo (ed.) La voz del otro; Testimonio, subalternidad y verdad narrativa. Número especial da Revista de crítica literária latinoamericana, año XVIII, n. 36, Lima, $2^{\circ}$ semestre, 1992, p. 181-199.

LEVI, Primo. A trégua. Trad.: Marco Lucchesi. São Paulo: Companhia das Letras, 1997.

. Entrevistas y conversaciones. BELPOLÍTI, Marco (ed.). Trad.: Francesc Miravitlles. Barcelona: Planeta, 1998.

. É isto um homem? Trad. Luigi Del Re. Rio de Janeiro: Rocco, 1988.

- Os afogados e os sobreviventes. Trad.: Luiz S. Henriques. Rio de Janeiro: Paz e Terra, 1990.

. O último natal de guerra. Trad.: Maria do Rosário Toschi Aguiar. São Paulo: Berlendis\& Vertecchia Editores, 2002.

- Se não agora, quando? Trad.: Nilson Moulin. São Paulo: Companhia das Letras, 1999. 
LINS, Osman. L Lima Barreto e o espaço romanesco. São Paulo: Ática, 1976.

LUKÁCS, Georg. A teoria do romance. Trad. José Marcos Mariani de Macedo. São Paulo: Duas Cidades Editora 34, $1^{\text {a }}$ ed., 2000.

1965.

Ensaios sobre Literatura. Rio de Janeiro: Ed. Civilização Brasileira,

MACHADO, José Pedro. Dicionário etimológico da língua portuguesa. Lisboa: Livros Horizonte, 1967.

MALRAUX, André. L'homme précaire et la littérature. Paris: Gallimard, 1977.

MARQUES, R. M.. "Tempos modernos, poetas melancólicos" in SOUZA, E. M. Modernidades tardias. Belo Horizonte: Ed. UFMG, 1998.

MAYORAL, Marina. El personaje novelesco. Madrid: Ediciones CátedraMinisterio de Cultura, 1990.

MENDILOW, A. A.. O tempo e o romance. Trad.: Flavio Wolf, Porto Alegre: Ed. Globo, 1972.

MENESES, Adélia Bezerra de. Do poder da palavra: ensaios de literatura e psicanálise, São Paulo: Duas Cidades, 1995.

MEYERHOFF, Hans. O tempo na Literatura. Trad.: Myriam Campello. S. Paulo: Ed. McGrawHill do Brasil Ltda, 1976.

MOORS, Ximena. "Para una arqueología del testimonio: el rol de la Iglesia Católica en la producción textual (1973-1991)" in Revista Iberoamericana, v. LXII, n.176-177, julio-diciembre 1996, p. 1161-1176.

MORAES, Eliane Robert. "A memória da fera: as representações do mal segundo Georges Bataille" in NESTROVSKI, Arthur e SELIGMANN-SILVA, Márcio (orgs.) Catástrofe e representação. São Paulo: Escuta, 2000, p. 149-156.

MOTTA, Leda Tenório da. "Céline diante do extremo" in NESTROVSKI, Arthur e SELIGMANN-SILVA, Márcio (orgs). Catástrofe e representação. São Paulo: Escuta, 2000, p. 157-167. 
MUIR, Edwin. A estrutura do romance. Porto Alegre, R.S.: Ed. Globo, 1928.

NASCIMENTO, F. S.. A estrutura desmontada. Fortaleza: Imprensa Universitária da U.F.C., 1972.

NAVES, Maria del Carmen Bobes. Teoría general de la novela. Madrid: Editorial Gredos, 1985

NESTROVSKI, Arthur; SELIGMAN-SILVA, Márcio. "Apresentação" in NESTROVSKI, Arthur e SELIGMANN-SILVA, Márcio (orgs.). Catástrofe e representação. São Paulo, Escuta, 2000, p. 7-12.

NESTROVSKI, Arthur. "Vozes de criança" in NESTROVSKI, Arthur e SELIGMANN-SILVA, Márcio (orgs.). Catástrofe e representação. São Paulo: Escuta, 2000, p. 185-205.

NOVAIS, Adauto (org.). A crise da razão. São Paulo: Companhia das Letras, 1996.

. Civilização e Barbárie. São Paulo: Companhia das Letras, 2004.

. O avesso da liberdade. São Paulo: Companhia das Letras, 2002.

- O Olhar. São Paulo: Companhia das Letras, 1988.

NUNES, Benedito. O tempo na narrativa. S. Paulo: Ed. Ática, 1988.

PÁL PELBART, Peter. "Cinema e holocausto" in NESTROVSKI, Arthur e SELIGMANN-SILVA, Márcio (orgs.). Catástrofe e representação. São Paulo: Escuta, 2000, p. 171-183.

Poemas en francés. Disponível em: $<$ http://poemasenfrances.blogspot.com/2006/02/ren-char-la-libert.html>. Acesso em 19 nov. 2008.

POUILLON, Jean. O tempo no romance. Trad.: Heloysa de Lima Dantas. São Paulo: Editora Cultrix Edusp, 1974.

RAMOS, Graciliano. Memórias do cárcere. SODRÉ, Nelson Werneck. (prefácio), 34ª edição, v I - II, Rio de Janeiro - São Paulo: Record, 1998. 
RAMA, A.; AGUIRRE, I.; ENZENSBERGER, H. M.; GALICH, M.; JITRIK, N.; SANTAMARÍA, H. "Conversación en torno al testimonio" in Casa de las Américas, año XXXVI, n. 200, La Habana, julio-septiembre 1995, p. 122-125.

RANDALL, Margaret. "Qué es y cómo se hace el testimonio?" in BEVERLEY, John; ACHUGAR, Hugo (ed.) La voz del otro; Testimonio, subalternidad y verdad narrativa. Número especial da Revista de crítica literária latinoamericana, año XVIII, n. 36, Lima, $2^{\circ}$ semestre, 1992, p. 21-45.

RICOEUR, Paul. O mal - um desafio à filosofia e à teologia. Trad.: Maria da Piedade Eça de Almeida. Campinas, São Paulo: Ed. Papirus, 1988.

- Tempo e narrativa. Campinas, S. Paulo: Ed. Papirus, 1994.

ROSENFELD, Anatol. "Reflexões sobre o romance moderno" in Texto/Contexto I. São Paulo: Perspectiva, 1996.

"As Causas Psicológicas do Nazismo" in Texto/Contexto II. São Paulo: Perspectiva, 2000.

SCHOLES, Robert \& KELLOGG, Robert. A natureza da narrativa. Trad.: Gert Meyer. São Paulo: Ed. Mcgraw-Hill do Brasil Ltda, 1977.

SCHOPENHAUER, Arthur. Metafísica do Amor- Metafísica da morte. Trad.: Jair Barboza. São Paulo: Martins Fontes, 2000.

SEGRE, Cesare. As estruturas e o tempo. S. Paulo: Ed. Perspectiva, 1986.

SELIGMANN-SILVA, Márcio. "A história como trauma" in NESTROVSKI, Arthur e SELIGMANN-SILVA, Márcio (orgs.). Catástrofe e representação. São Paulo: Escuta, 2000, p. 73-99.

"Auschwitz: história e memória" in Pro-posições, v. 1, n. 2 (32), julho/2000, p. 78-87.

. (org.) História, memória e literatura. O testemunho na era da catástrofe. São Paulo: Editora da Unicamp, 2003.

- Literatura e trauma: um novo paradigma. Rivisti di studi portoghesi e brasiliani. Pisa-Roma, n. III, 2001, p. 103-118. 
"Zeugnis" e "Testimonio": um caso de intraduzibilidade de conceitos in Letras n. 22 - Literatura e autoritarismo, Santa Maria, n. 22, jan/jun - 2001, p. 121 130.

SKLODOWSKA, Elzbieta. "Miguel Barnet: hacia la poética de la novela testimonial" in Revista de crítica literaria latinoamerican, año XIV, n. 27, Lima, 1er semestre 1988, p. 139-149.

- Testimonio hispano-americano. Historia, teoria, poética. New York: Peter Lang, 1991, p.129.

. "Testimonio mediatizado: ¿Ventriloquía heteroglosia? (Barnet/Montejo; Burgos/Menchú)" in Revista de crítica literária latinoamericana, año XIX, n. 38, Lima, $2^{\circ}$ semestre 1993, p. 81-90.

SMORKALOFF, Pámela. "De las crónicas al testimonio: sociocrítica y continuidad histórica en las letras latinoamericanas" in Nuevo texto crítico, año IV, n. 8, $2^{\circ}$ semestre 1991, p.101-115.

SOMMER, Doris. "Sin secretos" in BEVERLEY, John; ACHUGAR, Hugo (ed.) La voz del otro; Testimonio, subalternidad y verdad narrativa. Número especial da Revista de crítica literária latinoamericana, año XVIII, n. 36, Lima, $2^{\circ}$ semestre, 1992, p.135-153.

SOUSA, Eudoro de. Mitologia I - Mistério e Surgimento do Mundo. $2^{\mathrm{a}}$ edição, Brasília: Ed. Unb, 1995.

SOUVAGE, Jacques. Introducción al estudio de la novela. Barcelona: Editorial Laia, 1981.

STEELE, Cyntia. "Testimonio y autoridad en Hasta no verte Jesus mío de Elena Poniatowska" in BEVERLEY, John; ACHUGAR, Hugo (ed.) La voz del otro; Testimonio, subalternidad y verdad narrativa. Número especial da Revista de crítica literária latinoamericana, año XVIII, n. 36, Lima, $2^{\circ}$ semestre, 1992, p. 155180.

TACCA, Oscar. O estilo indirecto libre y las maneras de narrar. Buenos Aires: Ed. Kapelusz, 1986. 
TODORV, Tzvetan. Estruturalismo e poética. São Paulo: Cultrix, 1968.

. As estruturas narrativas. Trad.: Leila Perrone-Moisés, SP: Perspectiva, 2004.

VALLEJO, César. Obra Poética Completa. AGUIRRE, Enrique Ballón. (editor, prólogo y cronología) Obra Poética Completa - César Vallejo (1892-1938). Caracas, Venezuela: Biblioteca Ayacucho, 1985.

VAN ROSSUM-GUYON, Françoise e SALLENAVE, Philippe Hamon-Daniele. "O que é uma descrição?" in Categorias da narrativa. Trad.: Cabral Martins. Lisboa: Coleção Vega Universidade, s/d.

VENUTI, Lawrence. Escândalos da Tradução: por uma ética da diferença. Bauru, SP: Edusc, 2002.

WALDMAN, Berta e DE MARCO, Valeria. "A experiência do horror" in Cult, São PAULO, n. 53, Dez/2001, p. 15-17.

WALTER, Monika. "El cimarrón y una cimarronada: nuevos motivos para rechazar un texto y de la forma como este se nos impone" in BEVERLEY, John; ACHUGAR, Hugo (ed.) La voz del otro; Testimonio, subalternidad y verdad narrativa. Número especial da Revista de crítica literária latinoamericana, año XVIII, n. 36, Lima, $2^{\circ}$ semestre, 1992,p. 201-205.

WEINRICH, Harald. Estructura y función de los tiempos en el lenguaje. Madrid: Editorial Gredos, 1974.

WILKOMIRSKI, Binjamin. Fragmentos. Memórias de uma infância (1939-1948). Trad.: Sérgio Tellaroli. São Paulo: Companhia das Letras, 1998.

YUDICE, George. "Testimonio y concientización" in BEVERLEY, John; ACHUGAR, Hugo (ed.) La voz del otro; Testimonio, subalternidad y verdad narrativa. Número especial da Revista de crítica literária latinoamericana, año XVIII, n. 36, Lima, $2^{\circ}$ semestre, 1992, p. 207-227.

ZIMMERMAN, Marc. "El otro de Rigoberta: Los testimonios de Ignacio Bizarro Ujpan y la resistencia indígena en Guatemala" in BEVERLEY, John; ACHUGAR, 
Hugo (ed.) La voz del otro; Testimonio, subalternidad y verdad narrativa. Número especial da Revista de crítica literária latinoamericana, año XVIII, n. 36, Lima, $2^{\circ}$ semestre, 1992, p. 229-243. 